
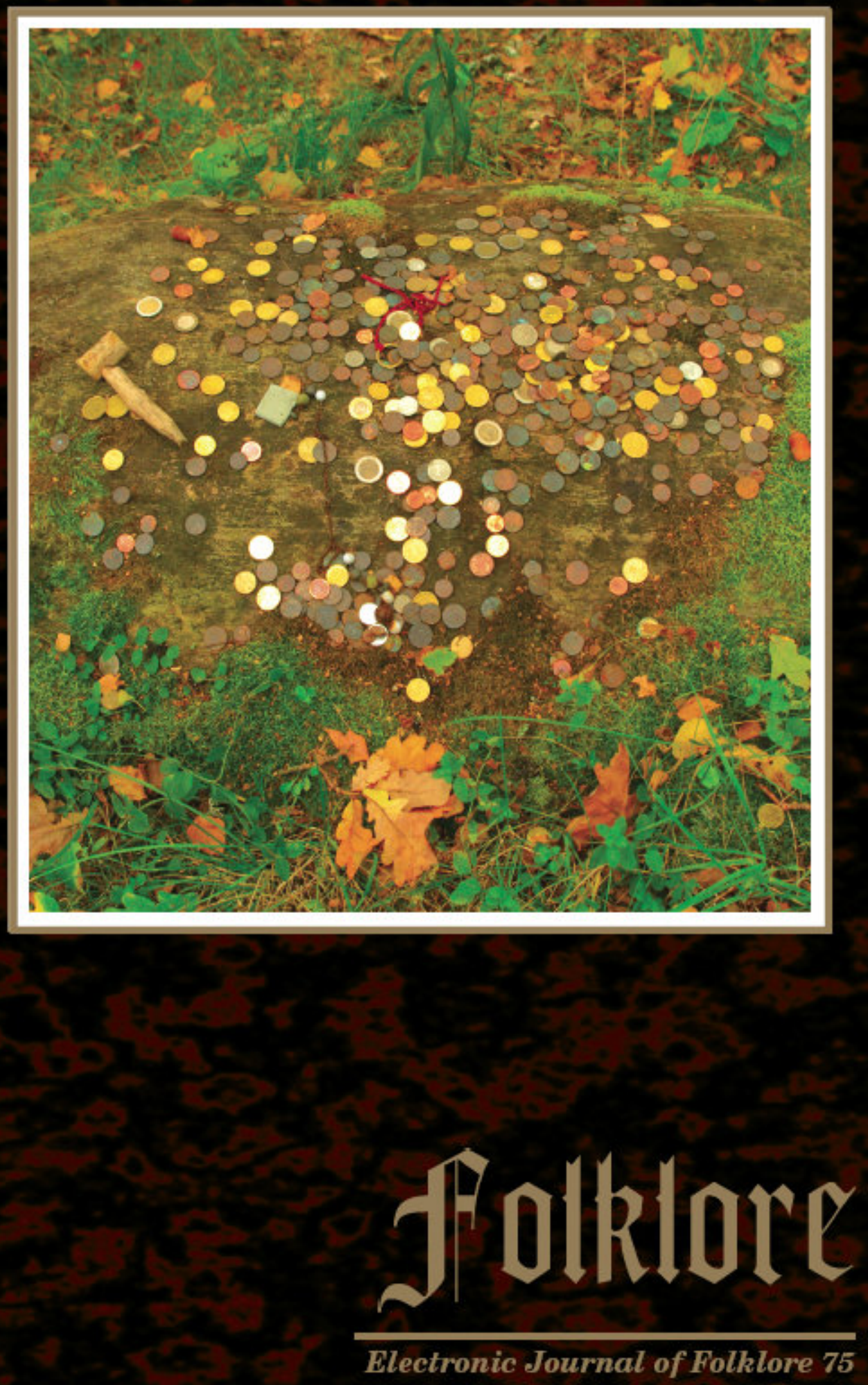


\section{Folklore}

Electronic Journal of Folklore

http://www.folklore.ee/folklore Printed version

Vol. 75

2019 
Folk Belief and Media Group

of the Estonian Literary Museum

Estonian Institute of Folklore

\section{Folklore}

Electronic Journal of Folklore

Vol. 75

Edited by Mare Kõiva \& Andres Kuperjanov

ELM Scholarly Press

Tartu 2019 
Editor in chief

Co-editor

Copy editor

News and reviews

Design

Layout
Mare Kõiva

Andres Kuperjanov

Tiina Mällo

Piret Voolaid

Andres Kuperjanov

Diana Kahre

Editorial board 2015-2020: Dan Ben-Amos (University of Pennsylvania, USA), Larisa Fialkova (University of Haifa, Israel), Diane Goldstein (Indiana University, USA), Terry Gunnell (University of Iceland), Jawaharlal Handoo (University of Mysore, India), Frank Korom (Boston University, USA), Jurij Fikfak (Institute of Slovenian Ethnology), Ülo Valk (University of Tartu, Estonia), Wolfgang Mieder (University of Vermont, USA), Irina Sedakova (Russian Academy of Sciences).

The journal is supported by the Estonian Ministry of Education and Research (IUT 22-5), the European Union through the European Regional Development Fund (Centre of Excellence in Estonian Studies), the state programme project EKKM14-344, and the Estonian Literary Museum.

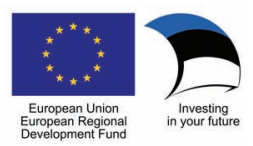

Indexed in EBSCO Publishing Humanities International Complete, Clarivate Analytics Web of Science (Arts \& Humanities Citation Index), MLA International Bibliography, Ulrich's Periodicals Directory, Internationale Volkskundliche Bibliographie / International Folklore Bibliography / Bibliographie Internationale d'Ethnologie, Open Folklore, C.E.E.O.L., Scopus

\section{Editorial address:}

Folklore: Electronic Journal of Folklore

Vanemuise 42-235

51003 Tartu

Estonia

phone: $\quad+3727377740$

fax: $\quad+3727377706$

e-mail: folklore@folklore.ee

home page: http://www.folklore.ee/folklore

All rights reserved

(C) Estonian Literary Museum

Estonian Institute of Folklore

Authors

Design Andres Kuperjanov

According to Creative Commons licence BY-NC-ND 4.0

ISSN 1406-0957

doi:10.7592/FEJF2019.75 


\section{CONTENTS}

Contemporary Deposits at Sacred Places: Reflections

on Contemporary Paganism in Estonia and Finland

Tõnno Jonuks, Tiina Äikäs

The Muong Epic Cycle of 'The Birth of the Earth and Water':

Main Themes, Motifs, and Culture Heroes

Nina Grigoreva

The Travelling Girl and Her Helpful Siblings: An Unnoticed Boreal Tale and the ATU Index

Yuri Berezkin

What Does the Storyteller Sing? On Transcribing the Epics of South Siberian Turks

Dmitriy Funk

Social and Political Criticisms Embedded in Chinese Myths and Legends

HE Xiyao

Context- and Belief-Related Aspects of Estonian Riddles

Piret Voolaid

Representing Sexuality through Folklore: Erotic Folktales and Online Jokes as 'Mirrors' of Gender Hierarchies

Aleksandar Takovski

Reluctant Entrepreneurs of the Russian Far East: Another View on the Economic Strategies of Entrepreneurs

Aimar Ventsel

"I Exist Therefore You Exist, We Exist Therefore They Exist": Narratives of Mutuality between Deities (Yul-Lha Gzhi Bdag) and Lhopo (Bhutia) Villagers in Sikkim

Kikee D. Bhutia 


\section{News IN BRIEF}

International Conference on Belief Narratives in Folklore Studies:

Narrating the Supernatural. Saša Babič

\section{BOOK REVIEW}

Gilgamesh as Calendric Year. Vladimir Sazonov 


\title{
CONTEMPORARY DEPOSITS AT SACRED PLACES: REFLECTIONS ON CONTEMPORARY PAGANISM IN ESTONIA AND FINLAND
}

\author{
Tõnno Jonuks \\ Senior Research Fellow, Department of Folkloristics \\ Estonian Literary Museum, Estonia \\ e-mail: tonno.jonuks@folklore.ee \\ Tiina Äikäs \\ Postdoctoral Researcher in Archaeology \\ University of Oulu, Finland \\ e-mail:tiina.aikas@oulu.fi
}

\begin{abstract}
This paper is based on fieldwork documenting contemporary deposits at sacred places in Estonia and Finland. We studied variations in these deposits in both countries and interpreted them on the basis of the known traditions of contemporary Paganism. Contemporary offerings bear evidence of the creative use of the past as well as international influences. The contemporary practices at sacred places, as demonstrated by material evidence, can be grouped under the following concepts: perceived continuity, revitalising traditions, syncretism, and ritual creativity. In Estonia, sacred places have been used more actively and more extensive deposits have accumulated than is the case in Finland. We also emphasise that sacred places are used by a broader variety of people than only members of Pagan communities, although other types of users are often ignored in research. The activities of the general public become visible particularly in the context of material culture studies, when all deposits are examined comprehensively.
\end{abstract}

Keywords: contemporary Paganism, deposits, material culture studies, sacred places

\section{INTRODUCTION}

Contemporary Paganism ${ }^{1}$ has grown rapidly in recent decades. Titus Hjelm (2016: 360) has stated that even though the recognition and research of different forms of contemporary Paganism have generally increased in the $2000 \mathrm{~s}$ and $2010 \mathrm{~s}$, "there is variation in the intensity of emergence of contemporary 
Paganisms in different social contexts". Contemporary Paganism consists of many different branches from the more universal groups of Wiccans, druids, and neo-Shamans to local ethnic Paganisms and reconstructionalists (see Sjöblom 2000: 237). Eastern European Pagans differ from universal Paganisms, as their practices derive from what is believed to be national history, folklore, and customs, and they generally associate their beliefs with a limited geographical area and the pre-Christian traditions of a particular nation (see, e.g., Ivakhiv 2005). Such traditions are also called 'native', since these communities wish to emphasise their connection to the local history and nation. These groups usually have in common a perceived respectful relationship with nature and local sacred places (cf. Wallis 2003: 143). Thus, the growth of contemporary Paganism has also brought about an increase in contemporary deposits that have accumulated in large numbers at different places. When deposited in nature, these objects are directly or indirectly associated with traditional customs of venerating nature. Deposits are left as a personal sign of a wish or just the token of a visit. In various places, this has resulted in piles of rags and coins, but sometimes also more personal and unique objects are deposited.

The broader aim of this article is to provide an overview of contemporary deposits at sacred places and to study the reasons for visiting these places and depositing these objects. In this study, we concentrate on sacred places - natural sites that are currently used for leaving deposits and offerings. While additional criteria, such as sources or tradition, time, authenticity, or the purposes of visits, are usually associated with the definition of a sacred place (e.g. Kaasik 2007; Muinsuskaitseamet ${ }^{2}$ ), these factors are not considered as selection criteria in this study. The concept of a sacred place in this study therefore depends only on contemporary traditions and the presence of deposits, and it covers places that are protected by the Heritage Conservation Act, sites that have not (yet) gained this status, sites whose significance derives from oral tradition, and places that have been declared sacred only recently.

When we visited the sites, we recorded the contemporary deposits, taking field notes and photographs and paying special attention to different deposit categories. As archaeologists, we let the material remains speak for themselves. Data from interviews were used only to interpret the background of sites in Estonia and Finland. During this study, we did not conduct any structured interviews. The citations in this paper are based on our discussions with the informants during the fieldwork and e-mails exchanged prior to the fieldwork and while writing this article.

The comparison between Finland and Estonia is fruitful, as these two neighbouring countries form an interesting example with overlapping similarities 
and differences. The main languages of both countries belong to the Finno-Ugric linguistic family, which has led to an abstract national narrative of shared history, worldviews, and beliefs. Such a concept is most clearly expressed in the activity of the Finno-Ugric Society (e.g. Salminen 2008), but the idea of shared national narratives lies behind many folklore and history studies. The national narrative is exploited by contemporary Pagan communities in both countries, as some groups feel that they represent the continuation of old traditions. However, the major difference is that the contemporary Pagan movement in Estonia, maausk (Earth Belief), has gained a more official status, whereas in Finland it remains rather marginal, is loosely organised, and struggles with the question of legitimacy (Västrik 2015; Hjelm 2016).

\section{PAGANISM IN ESTONIA AND FINLAND}

It is rather difficult to estimate when and how contemporary Pagan traditions started in Estonia. In tandem with the development across Europe in the early twentieth century, a contemporary Pagan movement emerged in Estonia. The movement was called Taarausulised (Believers of Taara) after Tharapita, the only pre-Christian god known by name from the Chronicle of Henry of Livonia, dating back to the beginning of the thirteenth century (for more details see Vakker 2012). This movement had become inactive by 1940, when the Soviet occupation prohibited most religious organisations in Estonia and the leading members of the movement (mostly military officers and members with national sympathies) were deported to Siberia (ibid.: 192). The organisation was therefore disbanded in 1940, but individual members remained in Estonia and continued their activities in secret. On the etic level, following the national Pagan movement was probably seen as a part of resistance during the Soviet period.

During the 1960s and 1970s, a new generation, partly following the ideology of Taarausulised, came up with a new idea - maausk (Earth Belief), represented by an organisation named Maavalla Koda (The House of Earth), referring to the religion of the land (i.e. Estonia). In contrast to the earlier Taarausulised, members of the new movement, called Maausulised (Believers of the Earth), stated that the movement should not be classified as neo-Pagan, as they claimed to be following Estonian oral tradition and thus the original worldview of Estonians since time immemorial. ${ }^{3}$ Until the late $1980 \mathrm{~s}$, the movement was more or less invisible and remained a secret niche activity. The late 1980s saw the rise of all sorts of different religious movements, in the until then officially atheist society (Rohtmets \& Ringvee 2013), and the Maausulised movement also 
became an organised religion. Claiming to be following indigenous Estonian traditions, it fitted well into the broader mindset of the time, which emphasised nationality and the study and popularisation of Estonian culture and religion. In the 1990s, the activities of the Maausulised group remained limited, but the group has received nation-wide attention since the early $2000 \mathrm{~s}$, after its first campaign for the preservation of sacred places. Since then, several public campaigns have been organised to protect sacred places, which has offered a productive platform for the movement to popularise its views (for more details see Västrik 2015; Jonuks \& Oras \& Veldi 2018).

Leaving aside the academic arguments about the history and historical authenticity of the Maausulised movement, it is important to note that this movement has become highly influential not only among other contemporary Pagan movements but also in shaping contemporary Estonian identity (Jonuks 2018). For instance, in a poll from 2014 (Religious Trends in Estonia 2014), altogether $61.1 \%$ of respondents agreed that maausk is the real and original religion of Estonia, although only $4.1 \%$ identified themselves as Earth Believers. To quote Ringo Ringvee, this community has branded itself very successfully (Ringvee 2017: 64f.). Emphasising the uniqueness of Estonian culture, its great age, and its ability to preserve traditional phenomena that have long been forgotten in the rest of Europe, the movement has supported the national identity with pride. This viewpoint is indirectly supported by Estonian writers, who also combine the uniqueness of Estonians and their close relationship with nature (e.g., the trilogy by Valdur Mikita 2008, 2013, 2015). As a result, the views of this contemporary Pagan group are also shared by people who do not belong to this group but consider these views as characteristic of Estonians. It has also been supported by the activity of the Maausulised movement, in which the preservation and popularisation of cultural heritage has been more publicly visible than the spiritual practice (Jonuks \& Oras \& Veldi 2018). This is why their practices are so common and widely followed across the country, often with the reasoning that "these are our ancestors' customs". As a good example, even some pastors of the Estonian Lutheran Church share a similar approach and are active in protecting sacred groves (see below for more details). Various views are represented inside the community, some of them more radical, others more tolerant towards Christianity and modernisation. The ideological and religious background behind the practice of leaving deposits at sacred places also varies. The leaving of deposits is apparently one of the most visible and effective ways for the members of the Maausulised movement, as well as for outsiders, to express their support for the Pagan tradition in Estonia and, following the narrative established by this community, also to express their 
national identity. These are probably the reasons why the Pagan movement has gained such an influential position in Estonian society that the country is even advertised abroad as following "nature-loving precepts of neo-paganism" (Economist 2017). This is also why sacred places across Estonia are covered with deposits of very different origins.

Since the early 2000s, Finland has demonstrated a steady growth in the number of people identifying themselves as Pagan and there is also a growing number of webpages and discussion forums related to contemporary Paganism on the Internet (Hjelm 2016: 360). However, already in the mid-nineteenth century, the publication of the Finnish national epic Kalevala with its stories of sorcerers and magic led to attempts to revitalise the "old spiritual wisdom" in practice (Hjelm 2016: 362). However, it was only in the late 1970s that contemporary Paganism appeared in Finland in an organised form, using elements from Finnish folklore in its practice and aiming to reconstruct the folk religion (Heino 1997; Hjelm 2006: 35-36).

The late 1990s saw a resurgence in the interest in contemporary Paganism, which led to the formation of new associations. Lehto-Suomen luonnonuskontojen yhdistys ry (The Grove - association of Finnish nature believers; 'ry' stands for registered association), an organisation for nature believers, was established in 1998, and Pakanaverkko ry (The Pagan Network), an organisation for neoPagans and nature believers, was established in 1999. A second wave followed a decade later with Taivaannaula (Heaven's Nail), which was established in 2007, and Karhun kansa (People of the Bear) for Finnish Faith (suomenusko) followers, which was established in 2010 and registered as an officially recognised religious community in 2013, the first contemporary Pagan group to gain this status. Some Finnish Faith followers do not identify themselves as contemporary Pagans. Iiro Arola (2011) has used the term ethno-Pagan to refer to contemporary Pagans who see local pre-Christian tradition as their main source. For example, Karhun kansa describes its function on its website as follows:

The People of the Bear represents a Finnic ethnic tradition of belief. The main characteristics of our religious life are sublimating nature experiences, traditional calendar celebrations, family connections reaching to the afterworld, honouring different forces, especially the Bear, soul belief ... The People of the Bear gives its members the freedom to experience things within the limits of the Finnic worldview that traces its roots back to the ancient Ural. This is a living ethnic religion that has recognised the full depth of its roots. ${ }^{4}$ (emphasis by the authors) 
Taivaannaula is an organisation for promoting Finnish folk belief and tradition. It also emphasises continuity, not from prehistory but from folklore dating to historical times. It does not consider or promote itself as a religious community but aims to preserve and keep alive traditional Finnish culture and folk beliefs. For this purpose, the organisation started a project in 2013 to map Finnish hiisi sites (sacred places) to raise awareness of sacred places in nature and to improve their protection. Taivaannaula has also worked together with the Estonian Maavalla Koda, as the two organisations share many ideas and activities, as well as an approach to popularising their views and beliefs. Since their activities at sacred places have resulted in materials similar to those of contemporary Pagan groups and their work on hiisi sites has had a big impact on the recognition and use of sacred places, we include their activities in this study.

Contemporary Pagan movements, particularly the leading ones, are usually viewed as the major groups using sacred places. Thus, members of these movements have more or less shaped the common understanding of meanings and practices related to sacred places. Less attention is paid to other possible audiences, particularly alternative Pagan movements but also individual visitors. It is obvious that an organisation is easier to reach and study than isolated individuals, who either conduct their own rituals or interpret what they see. But it also means that a large part of the users of sacred places is often ignored in studies. As they also do leave deposits, this amorphous group, involving people from very different backgrounds, becomes visible in material culture studies.

\section{CONTEMPORARY DEPOSITS IN ESTONIA AND FINLAND}

In this article, we present deposits documented in surveys conducted at Estonian and Finnish sacred places that are used by contemporary Pagan groups or other groups that respect sacred places or express their beliefs, national identity, and so on, at natural sacred places. The survey in Estonia was conducted in September 2016 and included 16 sacred sites (Fig. 1). Most of these sites have been mapped occasionally over several years, providing background data that also demonstrated changes in deposits at sacred places. The fieldwork in Finland was conducted in April 2017, in south-western part of the country, ${ }^{5}$ where sacred places are actively used. In the Turku region, three members of the Taivaannaula organisation acted as guides. Other sites were selected using information from the introduction to the hiisi project ${ }^{6}$ and from an informant belonging to Karhun kansa. 


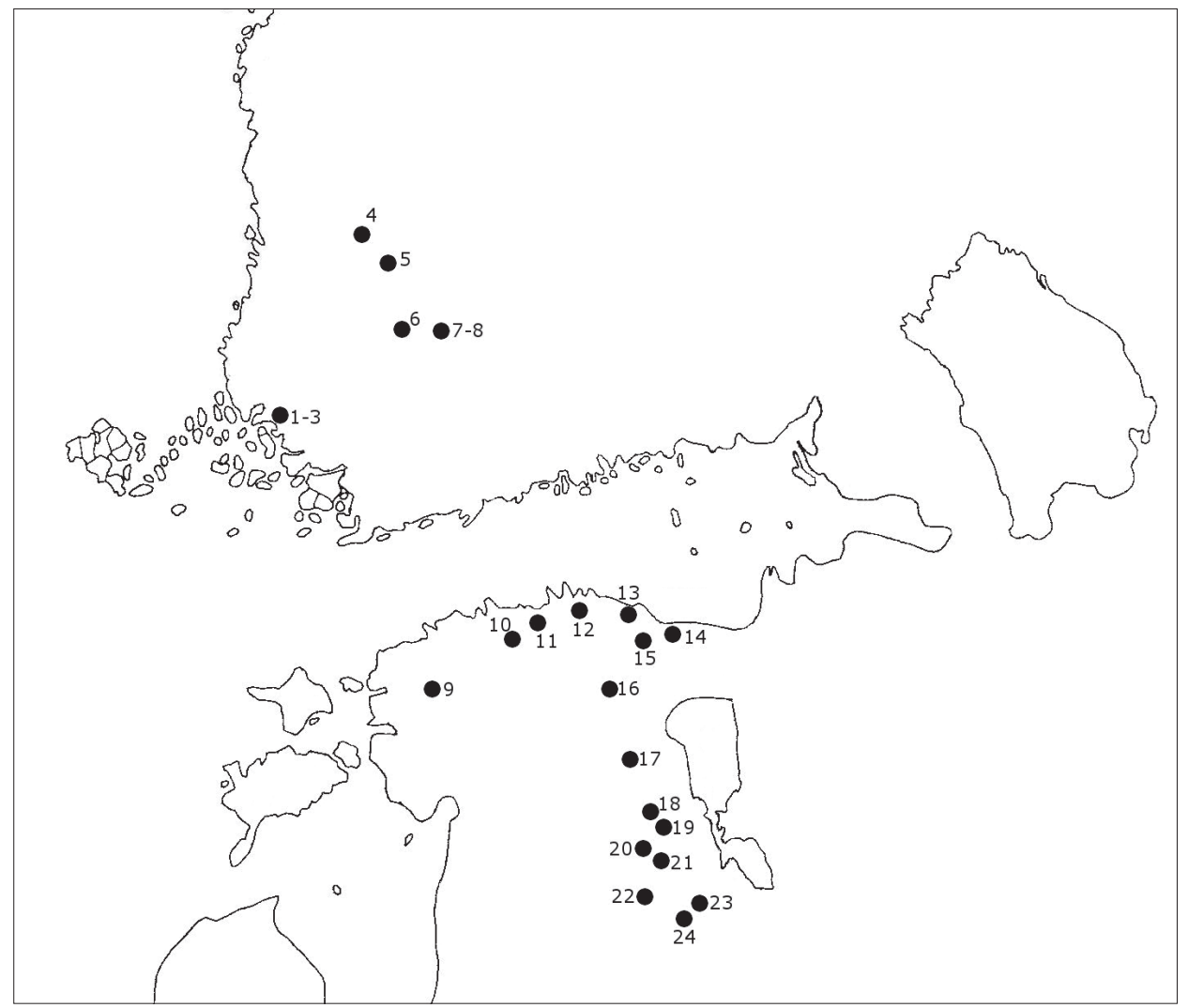

Figure 1. Map of sites in Finland and Estonia studied during fieldwork (drawn by T. Jonuks). 1. Uhrilähteenkatu, Muhkuri, Turku (sacred spring); 2. Hiisilähde, Vähäheikkilä, Turku (sacred spring); 3. Virnamäki, Turku (cup-marked stones); 4. Timin mänty, Hämeenkyrö (sacred pine); 5. Tapparamäki, Tampere (cairn); 6. Sääksmäki, Rapola (cupmarked stone and hill fort); 7. Pikkuvahopää, Lepaa (cup-marked stone); 8. Tonttukivi, Lepaa (sacred stone); 9. Sipa (sacred tree); 10. Pärnamäe (sacred grove); 11. Kuusalu (offering stone); 12. Ilumäe (sacred tree); 13. Kunda (sacred hill); 14. Purtse (sacred hill); 15. Samma (sacred grove); 16. Ebavere (sacred hill); 17. Kassinurme (sacred grove); 18. Kiigeoru (sacred grove); 19. Võnnu (sacred tree); 20. Taevaskoja; 21. Rosma (sacred grove); 22. Tohkri Tammetsõõr (sacred grove); 23. Hinniala Päevapööramise Hill (sacred hill); 24. Miikse Jaanikivi (sacred stone).

\section{Coins and silver}

Estonian contemporary deposits at sacred places are characterised by their great variety but are dominated by coins and ribbons. Both are globally universal groups of deposits and also recommended by the local Pagan groups. 
These categories have references in historical sources from Estonia, as well as in oral tradition from the late nineteenth and early twentieth centuries (see, e.g., Busch 1937: 65-66; Valk 2001 [1999]; Jonuks \& Friedenthal \& Haak 2010), and some rare examples have ended up in archaeological collections. Coins have been deposited more frequently starting from the seventeenth century, when they lost their monetary value and became cheaper and thus also available for symbolic use (Jonuks \& Friedenthal \& Haak 2010: 277) (Fig. 2). Since then, coins have been most often mentioned as 'superstitious offerings' of local peasants (see Valk 2015 in more detail). In the late eighteenth century and during the nineteenth century, the depositing of coins became a touristic habit and coins started to be left at touristic places - in particular at springs and wells, but also in caves (Laime 2018). This is most probably also the background of most of the coins from Estonian sacred places during the twentieth century. In very few cases has it been demonstrated how coins were deposited throughout the twentieth century (e.g. the Helme spring; see Valk 2015, 2018).

Although a touristic purpose is obvious in most coin deposit cases, it can be followed mainly at widely-known public sites, such as public fountains. The large number of coins deposited at sacred places might also have a more personal character, although at some well-known sites (e.g. the Helme spring),

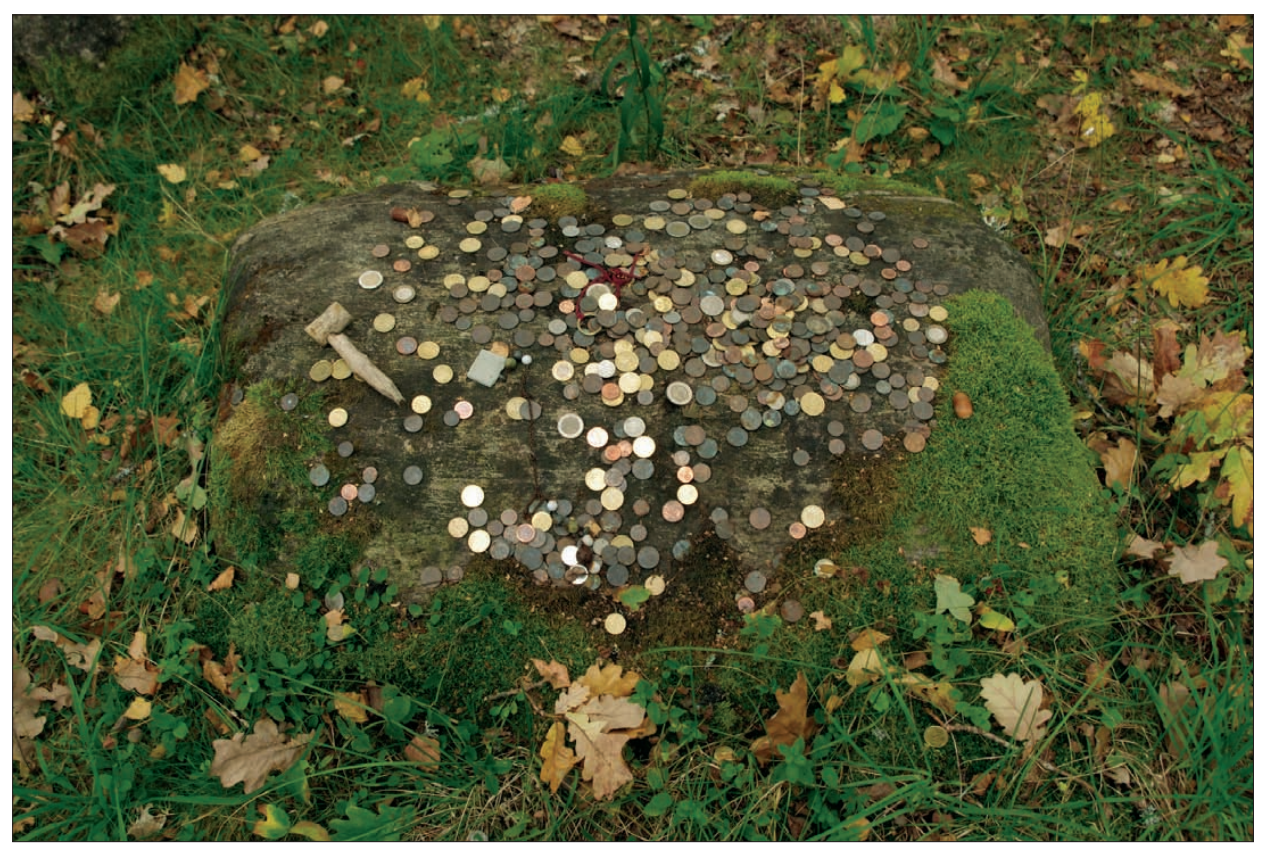

Figure 2. Coin deposits at Tammetsõorr, southern Estonia. Photograph by T. Jonuks 2016. 
touristic purposes dominate. Technically, contemporary coins follow the old traditions - usually of low nominal value, most probably left as single items, and, according to the available explanations, intended as a sign of a personal visit. Other and more specific purposes are also available, like healing magic that is also referred to in folklore collections (Valk 2007a: 145ff.). In the oral tradition, coins are described as a medium - in the case of skin diseases, the affected place is touched with a coin, and the disease is believed to be attached to the coin. Thus, when the coin is deposited into a spring or left on a stone, it is hoped that the disease is also anchored there. Such specific purposes can be more numerous, including very personal reasons to deposit a coin at a particular site.

Most of the deposited and documented coins represent local currencies, either Estonian cents and crowns (1992-2011) or euros and euro cents (since 2011). Soviet coins from the second part of the twentieth century are not equally visible, partly because coins are buried under the soil by natural accumulation. The lower number could also indicate the episodic use of sacred places. Publicly known touristic sites, on the other hand, have yielded large numbers of Soviet coins deposited there as part of touristic trips (Valk 2018). Coins connected to specific countries, such as Swedish crowns and Russian roubles, might be more informative. However, the interpretation is twofold again; foreign coins may be associated with the usual touristic practices in which coins are left because there are already coins at the site, or foreign coins may reflect personal purposes. For instance, members of the large Estonian community who left Estonia during World War II and now live in Sweden often visit their childhood home and its neighbourhood, and thus a coin from the new homeland deposited at a sacred place in the country of one's origin may serve as a mental link for a particular person. However, there are many personal reasons for depositing coins (or any other objects, see below), and even detailed interviews of visitors to sacred sites might not provide a comprehensive picture.

Also in Finland, coins were found on cup-marked stones as well as in an offering pine called Tim's pine (Timin mänty) (Fig. 3). Still, it is noteworthy that coins are much rarer at Finnish sites than at Estonian sites. At Tim's pine, the coins were put in cracks in the bark. Both cup-marked stones and the offering pine are visited by tourists as well as by contemporary Pagans, so that it cannot be distinguished which group has left the coins. All documented coins were small euros and cents.

Whereas coins are used by a heterogeneous group of people, scraped silver could be considered as belonging to the area of revitalised folk beliefs. During our fieldwork, we were able to observe how a member of Taivaannaula scraped silver into the offering springs that we visited (Fig. 4). This tradition was so important to him that when, at one site, he noticed that he had left his knife 


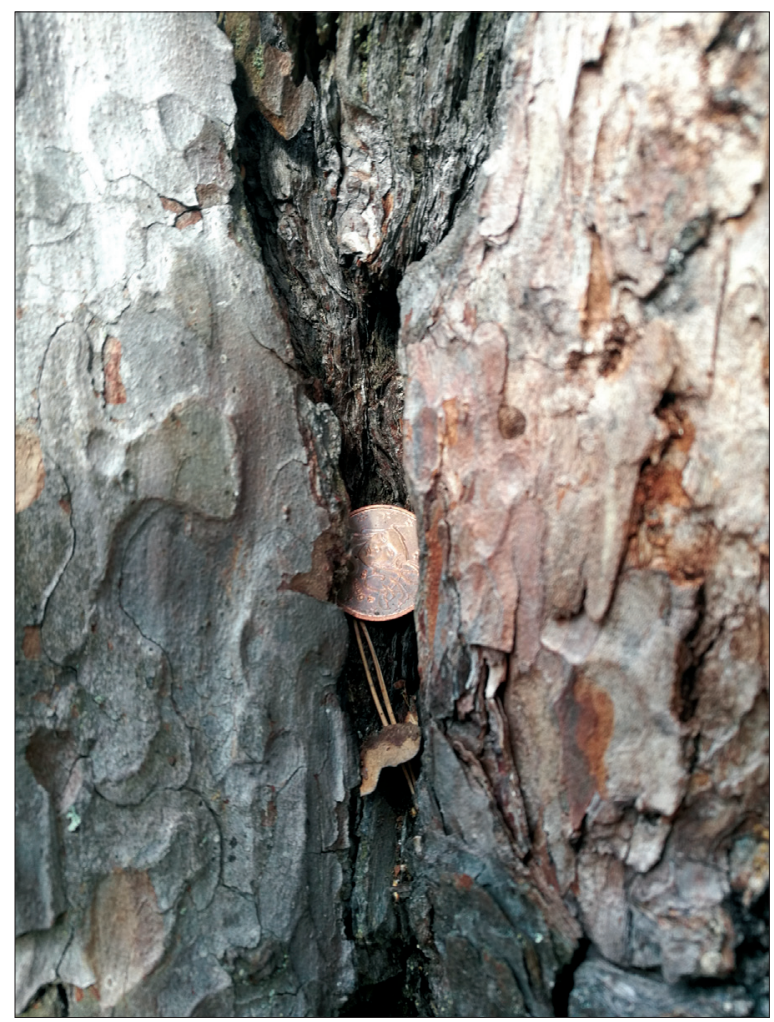

Figure 3. A coin deposited at Tim's pine. Photograph by T. Äikäs 2017.

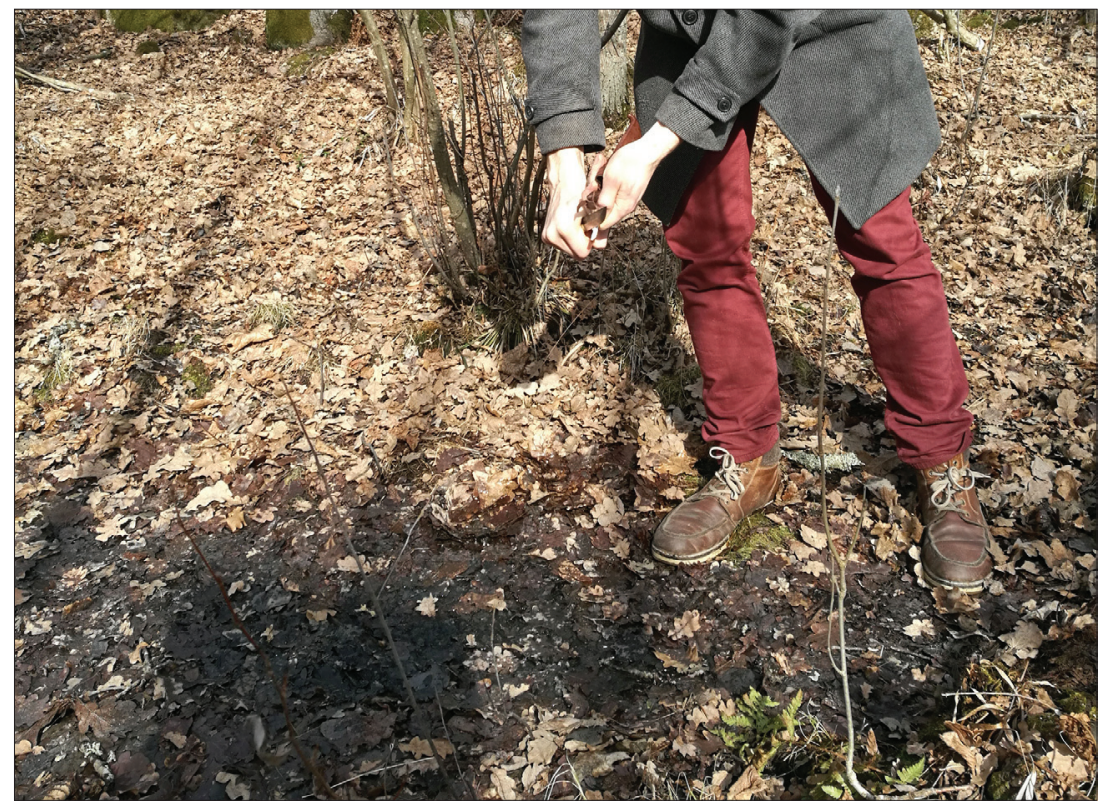

Figure 4. Scraping of silver. Photograph by T. Äikäs 2017. 
in the car, he went back to collect it. The scraping of silver at sacred places, particularly at springs, is also common in Estonian contemporary Pagan tradition. In Taevaskoja, southern Estonia, there is an information board with text and a picture instructing visitors on how to offer silver. The scraping of silver, but also other metals, such as copper, has been a widespread practice also in history, as indicated by dozens of silver brooches from the nineteenth and twentieth centuries in the collections of the Estonian National Museum. Eight of them have a legend saying that the brooches were used to scrape silver, while forty other brooches have similar scraping marks, although the corresponding legend is missing (Kuningas 2014). However, this practice is difficult to observe without witnessing the actual ritual at sites, as the amount of scraped silver is small and quickly dispersed in the environment.

\section{Rags, ribbons, and other things tied to trees}

Rags and ribbons represent another broad and universal category of deposits. The earliest records from Estonia date already to the early seventeenth century (Olearius 1669: 33), and this deposit category has been represented ever since (Fig. 5). In some cases, the nails used to attach rags to a tree are also collected during archaeological excavations (Laid 1928). From the Soviet period we do not have documented examples of attached rags at sacred places. Rags and ribbons could still have been used, but documentary evidence is missing. Instead, during this period rags were frequently used during wedding ceremonies and attached to posts and trees that held stork nests (Hiiemäe 1997: 15). This is related to the widespread folk tradition of storks being connected with fertility and childbirth (ibid.). The tradition of decorating stork nest bases with colourful rags is still common, although no specific study of this custom has been conducted so far.

Considering the universal tradition of leaving rags at different sites (e.g. Houlbrook 2016) and particularly considering their popularity in Estonia, it is surprising that the tradition is almost absent at Finnish sacred places, although there are a few references to it, for example in the case of Tim's pine (see below). The reason for the lack of rags and ribbons in Finland might be related to the fact that revitalising the use of sacred places in southern Finland is a relatively recent phenomenon. This tradition might nevertheless have also begun in Finland. It has grown somewhat in popularity after the start of the hiisi project in 2013. Our informant from Taivaannaula mentioned that the tradition of attaching ribbons to sacred trees was revitalised in Virmapyhä in Jämsä at the time of our fieldwork and people were encouraged to leave rags on trees. With the help of this information, we can currently follow the process of how a revitalised tradition is introduced into the Finnish context. 


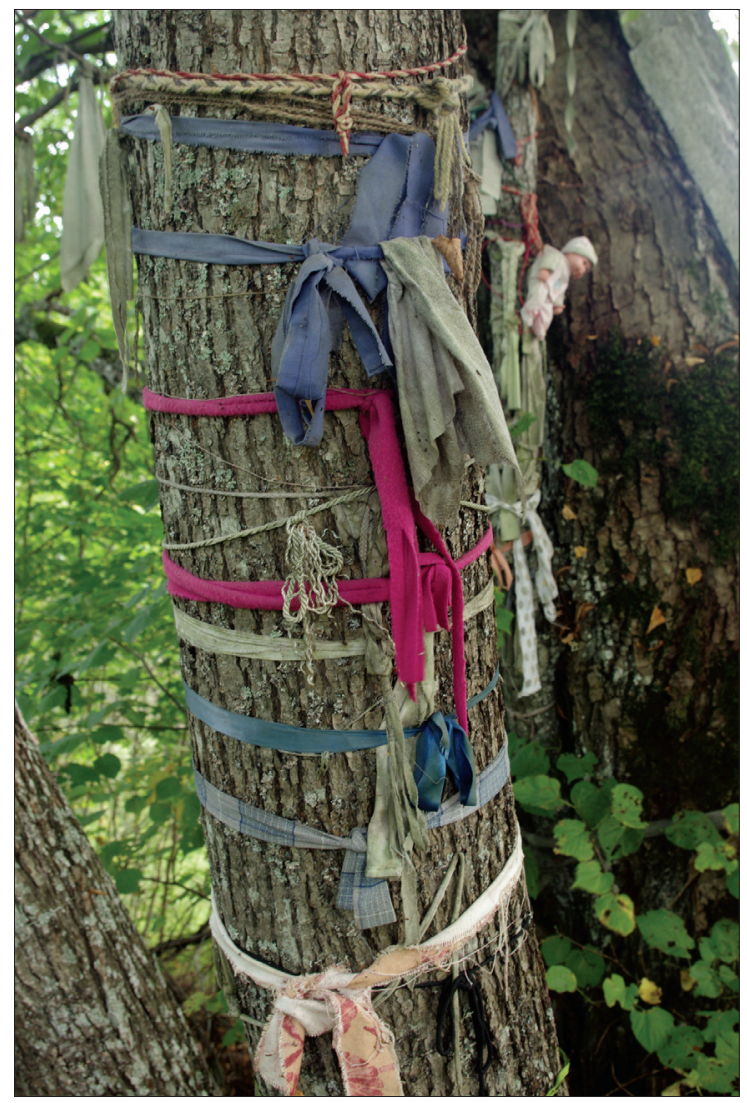

Figure 5. Rags and ribbons at Ilumäe (a) and Pärnamäe (b).

Photographs by T. Jonuks 2016.

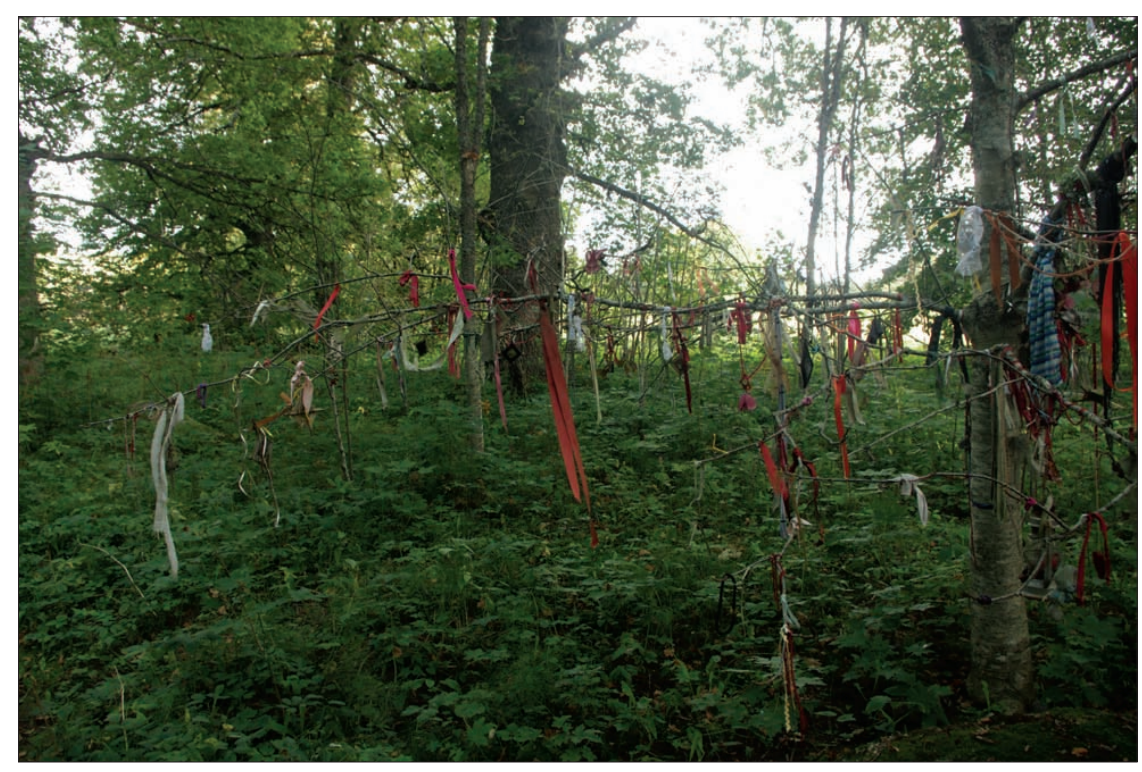


The contemporary Pagan community in Estonia has also contributed significantly to the popularisation of attaching rags, claiming it to be an old and unbroken tradition (Kaasik 2007: 44). Since the late 1980s, it was recommended to attach rags at sacred places with references to folklore and the Early and Modern Age descriptions. These recommendations were willingly adopted and began to be practised widely during the 1990s. The custom grew out of control and all sorts of materials were used, among others plastic bags, reflectors, and Christmas decorations - everything that was handy and cheap (Fig. 6). As a result, sacred places were and still are scattered with rags, but also all sorts of different objects (Fig. 7). Most definitely, the practice of attaching rags to trees cannot be associated only with the spread of the contemporary Pagan tradition. Universal touristic traditions have had a considerable influence on this practice, but people have also (re)interpreted deposits that they already see. The latter is probably one of the most important reasons for leaving various bindable objects, which sometimes have obvious personal meanings. Since the 2000 s, the contemporary Pagan community has recommended using only organic materials, and later this evolved into a more personal practice where people were encouraged to weave ribbons themselves, preferably of red yarn (Fig. 8). Numerous self-made ribbons deposited since then indicate the ready acceptance of this recommendation and the active role of the contemporary Pagan group in shaping the way common people behave at sacred places, although plastic bags and other synthetic materials still appear.

In addition to rags and ribbons tied to the trees, in Estonia rags and yarn are also woven into more complex sets possibly carrying symbolic meanings. Due to the recommendation to use organic raw materials, woven items of natural and local materials, such as bark, grass, cones, and so on have also appeared (Fig. 9). Very rarely such materials have parallels in Estonian folklore, but organic and natural materials are easily associated with the contemporary ideology, which emphasises ecological and sustainable approaches. For scholars working with material objects, such deposits raise the interesting question of how to recognise intentional deposits after a certain period of time. This is also a good reminder of the fact that only a part of the offerings will be preserved at sites and that when any site is interpreted, the original variety of deposits could have been significantly broader, including organic materials, food, and so on. 


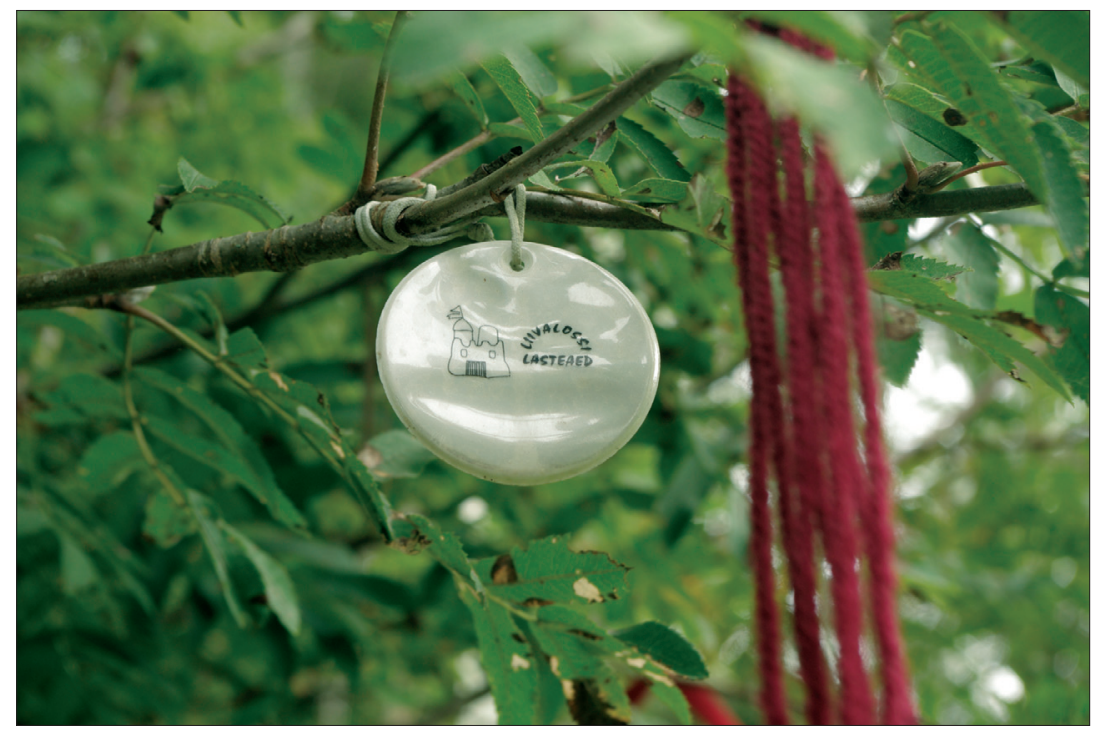

Figure 6. A reflector with the name of the Liivalossi kindergarten at Kassinurme. A deposit by an ordinary visitor or an organised trip by the kindergarten? Photograph by T. Jonuks 2016.

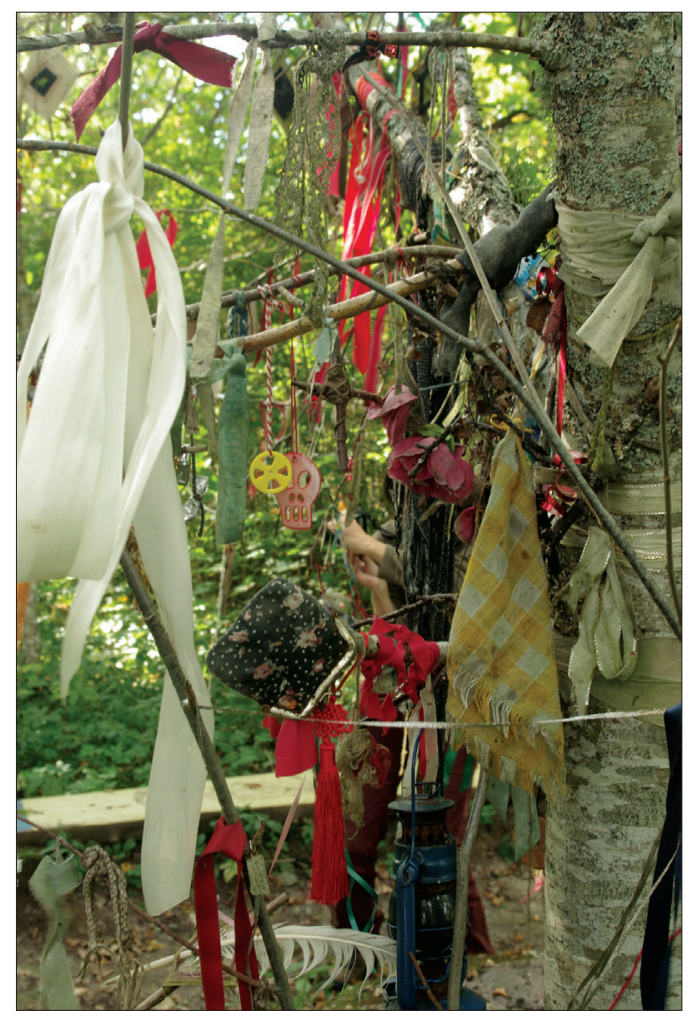

Figure 7. An example of various materials and objects hung on a tree at Pärnamäe. Photograph by T. Jonuks 2016. 
Figure 8. Self-made ribbons at Kiigeoru. Photograph by T. Jonuks 2016.

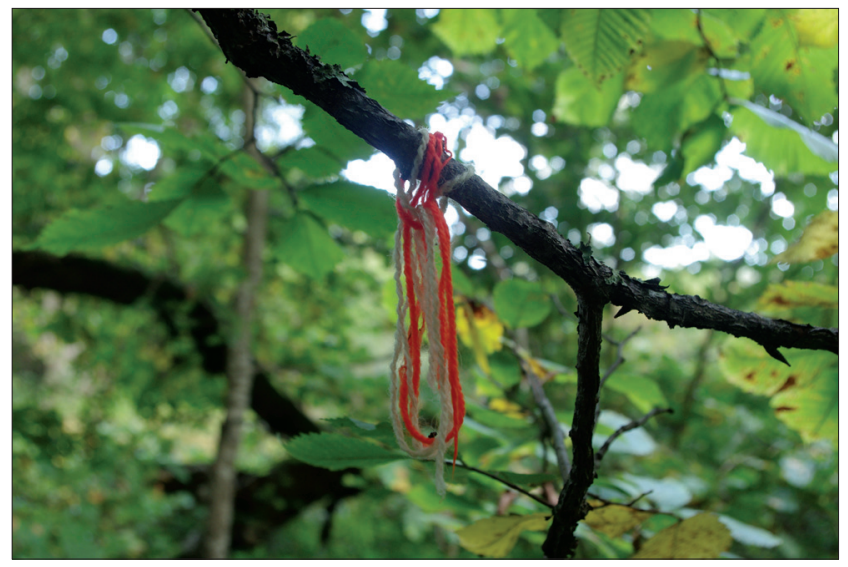

$a$

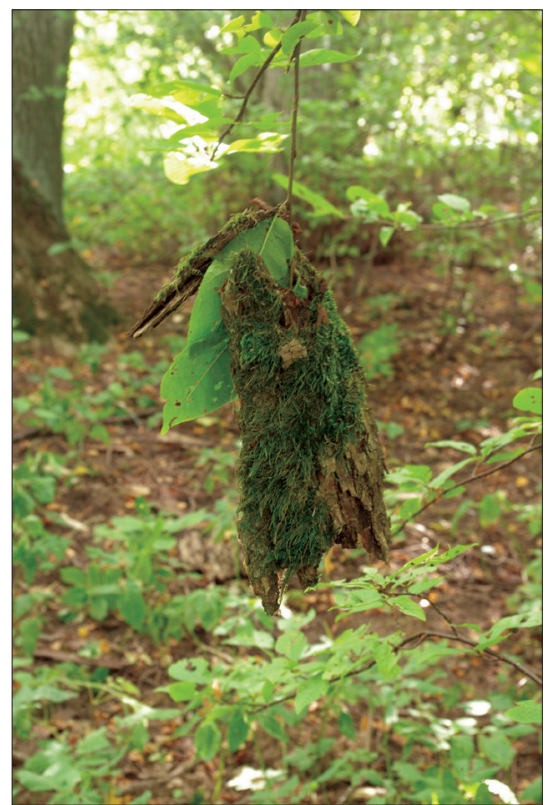

$b$

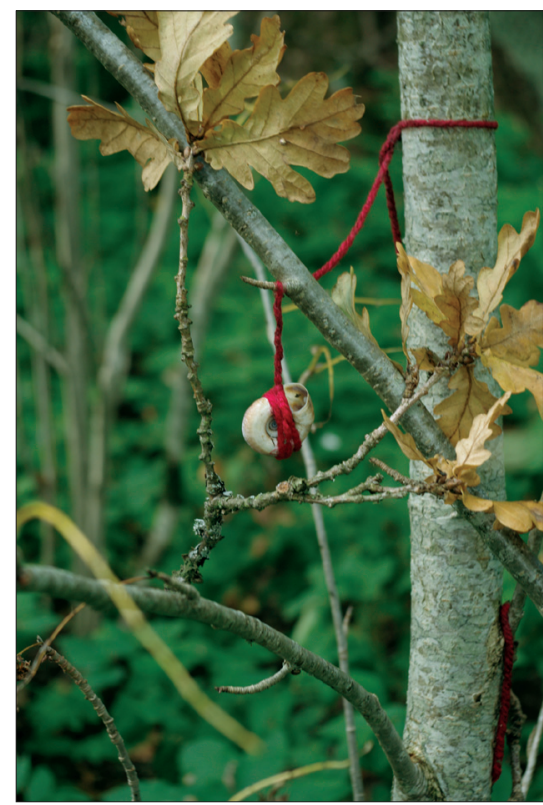

$c$

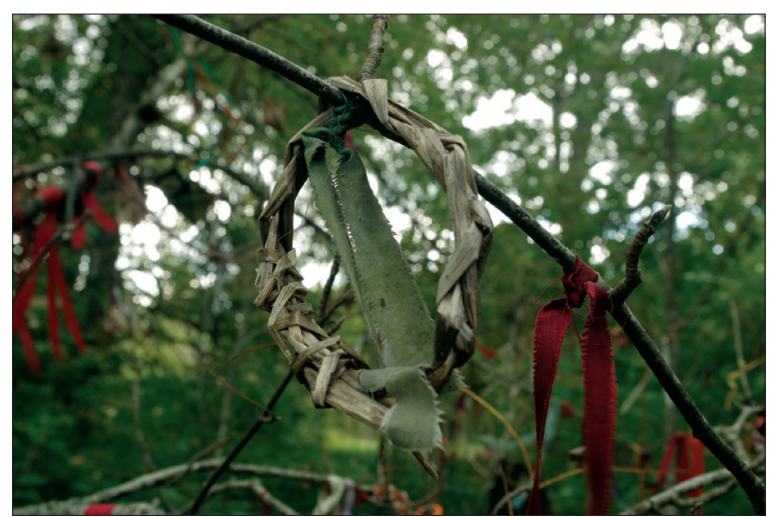

Figure 9. Natural deposits: tree bark (a), a snail shell (b), and a woven item (c) suspended from branches at Pärnamäe. Photographs by T. Jonuks 2016. 


\section{Children's toys}

The question of intentionality and purpose is critical also in the study of several other kinds of deposits. During the past few years, children's toys have emerged in Estonia as deposits at sacred places. They include, for example, toy cars, dolls, and teddy bears (Fig. 10). It is currently unknown who has left such deposits and for what purposes. Were they children or adults; were they members of a Pagan movement or just ordinary visitors? It is likely that children of the members of Pagan movements would follow the habits of adults of the same group and thus organic deposits would be expected instead of the usual plastic toys. A study conducted in the United States shows that at least there it is common for the children to follow their parents' Pagan spirituality (Fennell $\&$ Wildman-Hanlon 2017). The most common and widespread toys may rather reflect the occasional visit of children who have left a toy at the site just by following an already existing tradition.

\section{Food offerings}

According to the oral tradition, one of the most common materials to be left at sacred places is food (Fig. 11). Traditionally, berries, bread, and beer are mentioned in folklore, followed by meat and meat products, eggs, milk, and other items (see Valk 2007b for examples). However, for obvious reasons, food remains are rarely preserved. Often the descriptions only mention food deposits,

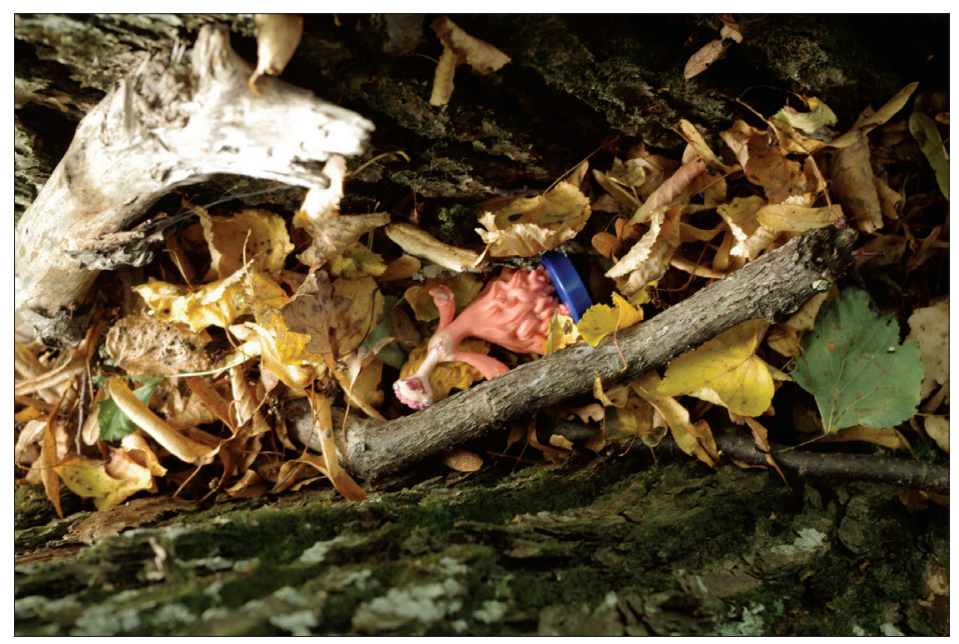

Figure 10. A children's toy figure concealed or fallen between two tree trunks at Ilumäe. Photograph by T. Jonuks 2016. 
leaving the impression that the informants have known about the tradition but not witnessed it. In 1889, a local woman described a sacred grove in central Estonia as follows:

People brought him [the god of Hiis/Hie] all kinds of things, new crops, wool, meat, dumplings, sausage, bread, buns, herring, salt, and so on, and thought and prayed that Hie would protect them and keep them from all unhappiness that inhibits the living. To keep animals from the holy site, a high fence was built around it. Still the offering holes (Hie augud) were revolting to see, since they contained pieces of clothing and meat and other food, which started to stink. This is what the people say. (H II 17, $127 / 9$ (2), translation by the authors).

$a$

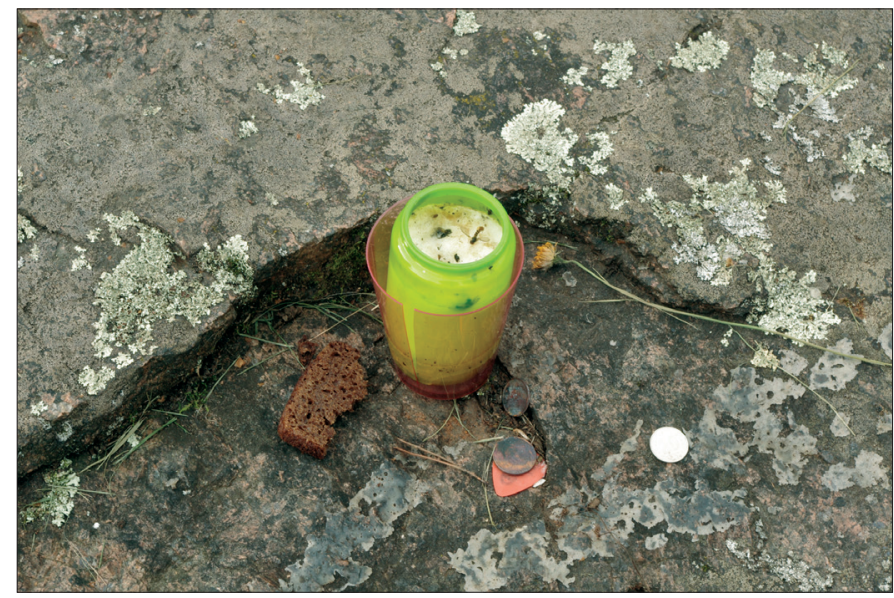

$b$

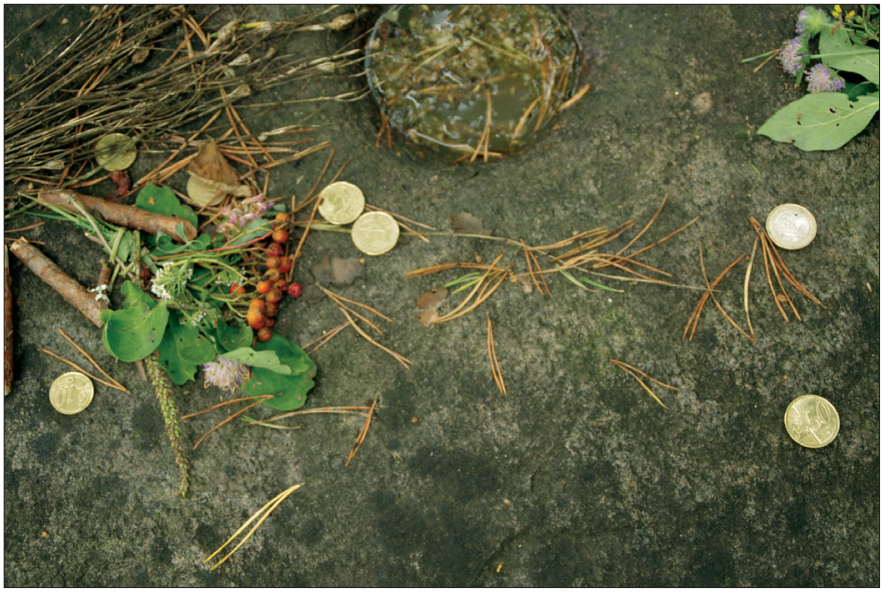

Figure 11. Bread, candles, and a coin at Kassinurme (a) and berries on top of the sacrificial stone at Samma (b). Photographs by T. Jonuks 2016. 
Such an emotional description of stinking offerings shows that the informant has most likely witnessed food offerings with her own eyes.

In the contemporary Pagan tradition, bread, porridge, and eggs are often deposited. Frequently food is deposited during calendar or communal rituals. In Virnamäki, Finland, food has been seen in the cup marks of a boulder after midsummer (Hukantaival, personal communication 2017). After All Saints' Eve, pieces of cabbage and a grave lantern with a burning candle were recorded at the same site (Fig. 12). However, these kinds of deposits disappear quickly and even eggshells are not preserved. A unique case was observed during this study in Finland: sugar was deposited into the cup marks of a boulder in Rapola, Sääksmäki. In addition, the leftovers of an unrecognised dried fruit or vegetable were found at the same place and bread had been noticed on the same cup-marked boulder already earlier. Without a doubt, foodstuffs have been and continue to be common materials for deposits, although they are quickly lost and difficult to study. In rare cases, the presence of dishes indicates food offerings. At Päevapööramisemägi Hill in southern Estonia, porringers and pots are stored (Fig. 13). This is a unique place - as it is not easily accessible and thus not a touristic site, it is mostly used by the members of Maausulised. Thus, the equipment for ritual porridge making is kept at the site, ready for use.

Candies have been left at several Estonian sites. On the roots of the Ilumäe linden tree, we observed a little basket once full of candies (Fig. 14). By the time of our visit, the candies were all gone, and only empty wrappers were left. A hole in the corner of the basket indicated that a mouse had consumed the candies, but people leaving the offering could also interpret the disappearance of the deposit as meaning that a spirit of the site had accepted the deposit. In some cases, candies have been found in Finland (e.g. Virnamäki, personal communication, Helena Ruotsala 2018). There is also ethnographic data of candies left in trees in Ingria by old people (Arukask 2017). In the latter case, the reason why candies were chosen for deposits is similar to the reason for choosing coins and ribbons: candies are rather cheap and handy, and wrapped candies can easily be carried in pockets. In 2018, another reason was suggested for using candies as an offering. According to oral tradition from Belarus, the purpose for depositing candies is the desire to secure a nice, sweet life, 'sweet as candy' (personal communication, Uladzimir Lobach 2018). All these reasons together make candies a very suitable deposit category. The actual reason can vary depending on the exact context. 
Figure 12. a-grain in the cupmarks of a boulder at Virnamäki after Midsummer (photograph by S. Hukantaival 2014); b - cabbage and a grave lantern with a candle on the same stone after All Saints' Eve (photograph by H. Ruotsala 2018).
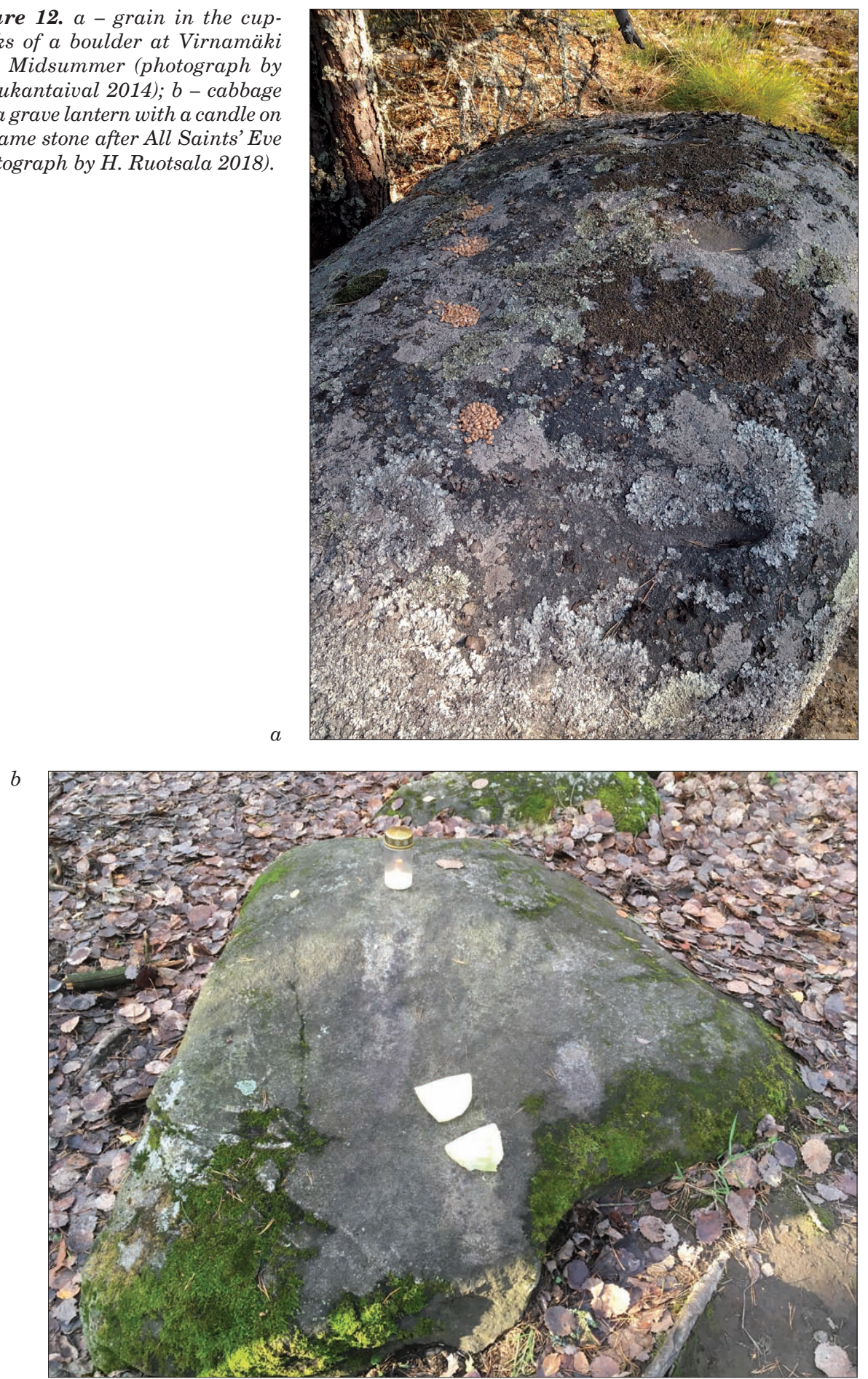

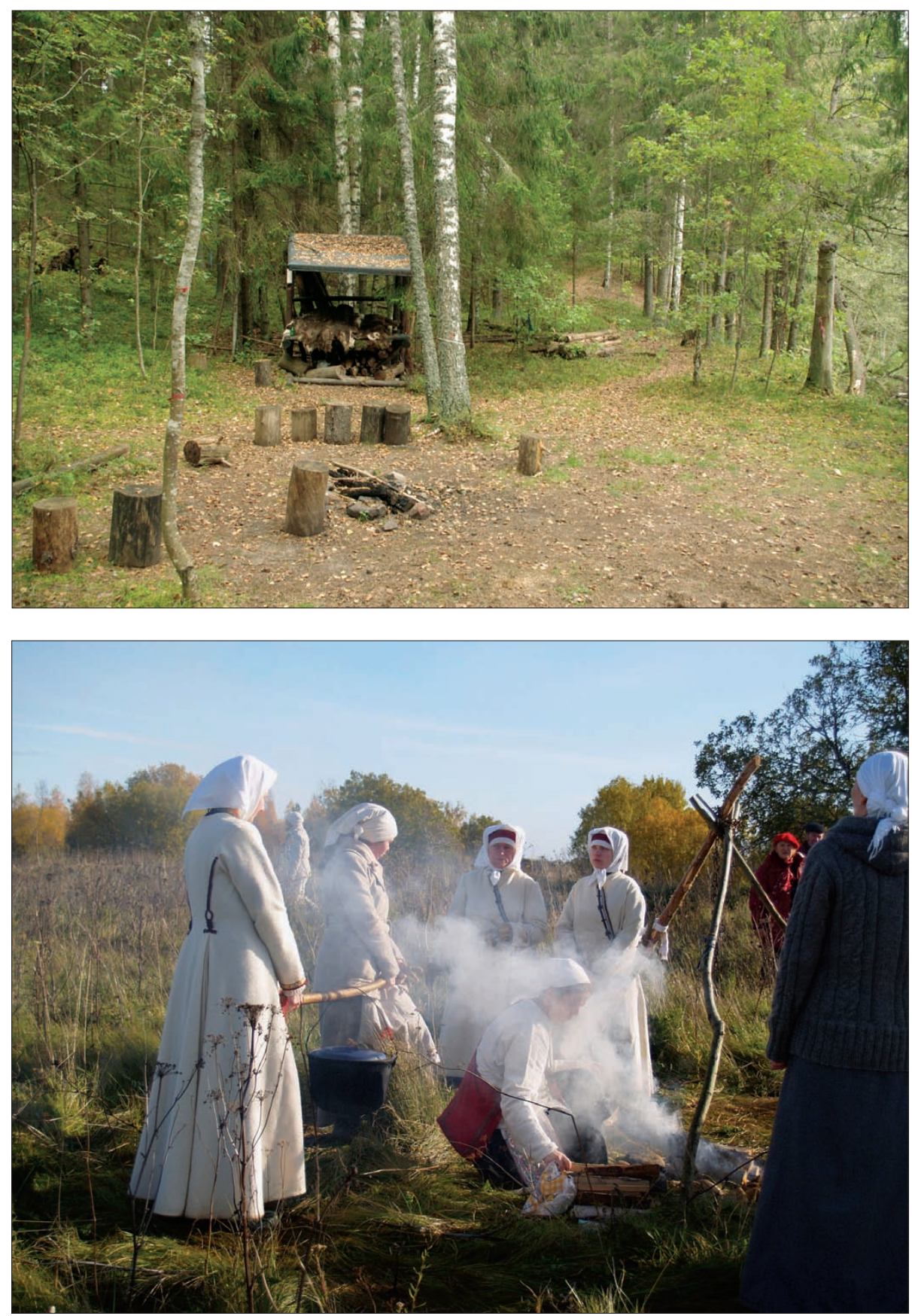

Figure 13. a - ritual site at the foot of the Päevapööramise Hill; fur and pots are stored in the shelter in the background (photograph by T. Jonuks 2016); $b$ - the members of Maavalla Koda making ritual porridge at the Kunda sacred hill (photograph by H. Maiberg 2009). 


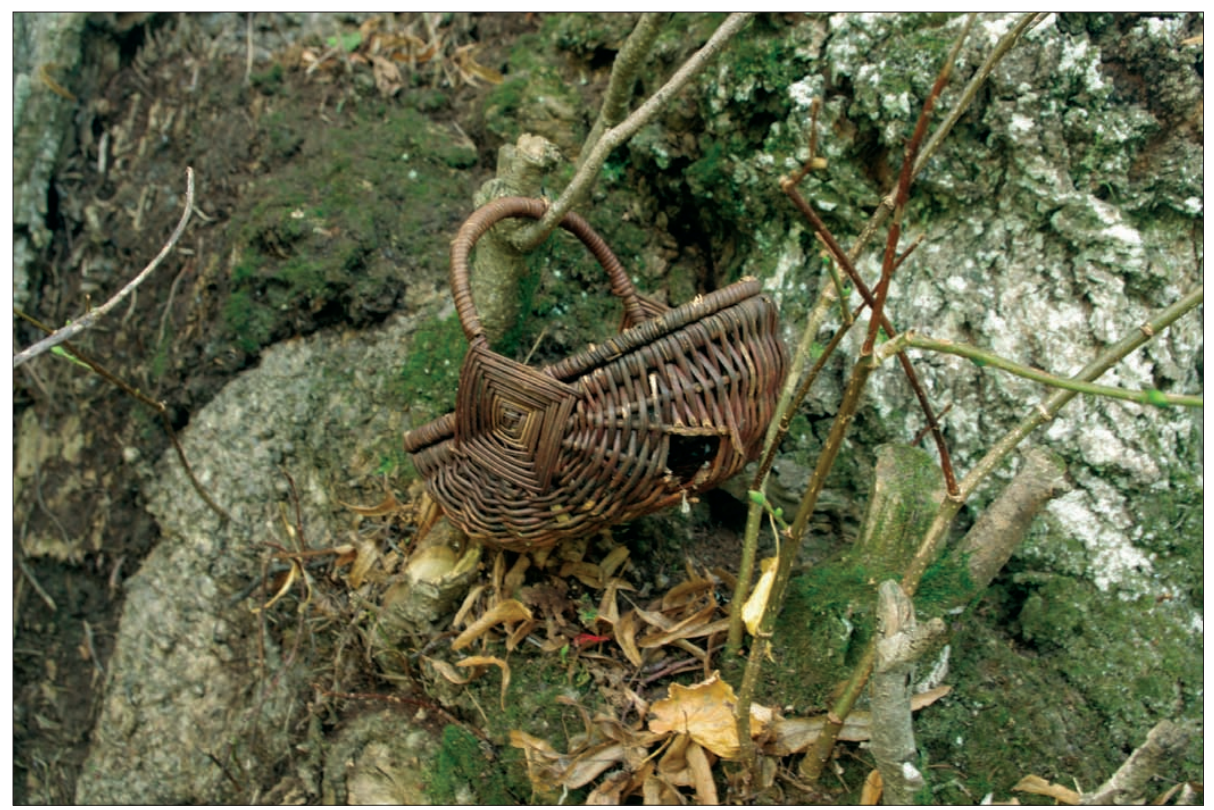

Figure 14. A basket with candy wrappers at Ilumäe. Note the hole chewed by a mouse in the corner. Photograph by T. Jonuks 2016.

\section{Love and charm}

Love magic is currently enjoying a wave of popularity (Hiiemäe 2017) and can in some cases manifest as deposits at sacred places. The best example of this is a little basket of offered apples and a postcard with a love spell on a stone below the Sipa linden tree in western Estonia (Fig. 15). Some other examples could also be associated with love magic or as humorous interpretations of it. At the Võnnu Mäesuitsu sacred tree (Tartu County, Estonia), a pair of men's socks was attached to the tree and a pair of female stockings left on the neighbouring branch (Fig. 16). Later on, other pairs of stockings were added to this tree, forming a good example of how one deposit can create a tradition that is reinterpreted by other visitors to the site. Still, in contrast to the Sipa example, the purpose is not clearly represented, and it can only be speculated whether the socks and stockings were tied to the tree because of reasons connected to love/fertility, just for fun, to reinterpret existing deposits, or for some other purpose. Moreover, leaving items of clothing and underwear at sacred sites is not a phenomenon unique to Estonia but has also been recorded in individual cases at a Sámi sacred place in northern Finland and more frequently in other countries (personal communication, Ross Parish 2017). Also twisted bracelets 
attached to tree branches at several places across Estonia could possibly be associated with love or personal relationships.

At Tim's pine in Väheenkyrö, Finland, a turquoise glass heart was deposited inside a hole in the tree (Fig. 17). This might also be an example of a loverelated offering. Of course, the deposit does not have to be associated with love towards another human being but could also be related to love expressed towards a divinity, spirit, or nature.

Most of the love magic seems to be the result of personal rituals. In unique cases, the remains of other and even more complicated rituals can be preserved. On top of Ebavere Hill, a site with a rather complicated history (for more details, see Jonuks \& Oras \& Veldi 2018), a shrine has been built. Its centre is formed of an altar made of three larger stones, and remains of burnt blond hair were observed beside it in 2014. A similar example of burning one's own hair as a ritual was documented at the Isogaisa shamanistic festival in northern Norway (Äikäs et al. 2018). It is likely that the burning of hair and nails is a part of magical activities in different religious systems and may therefore occur often but leave no remains to be preserved or recorded.

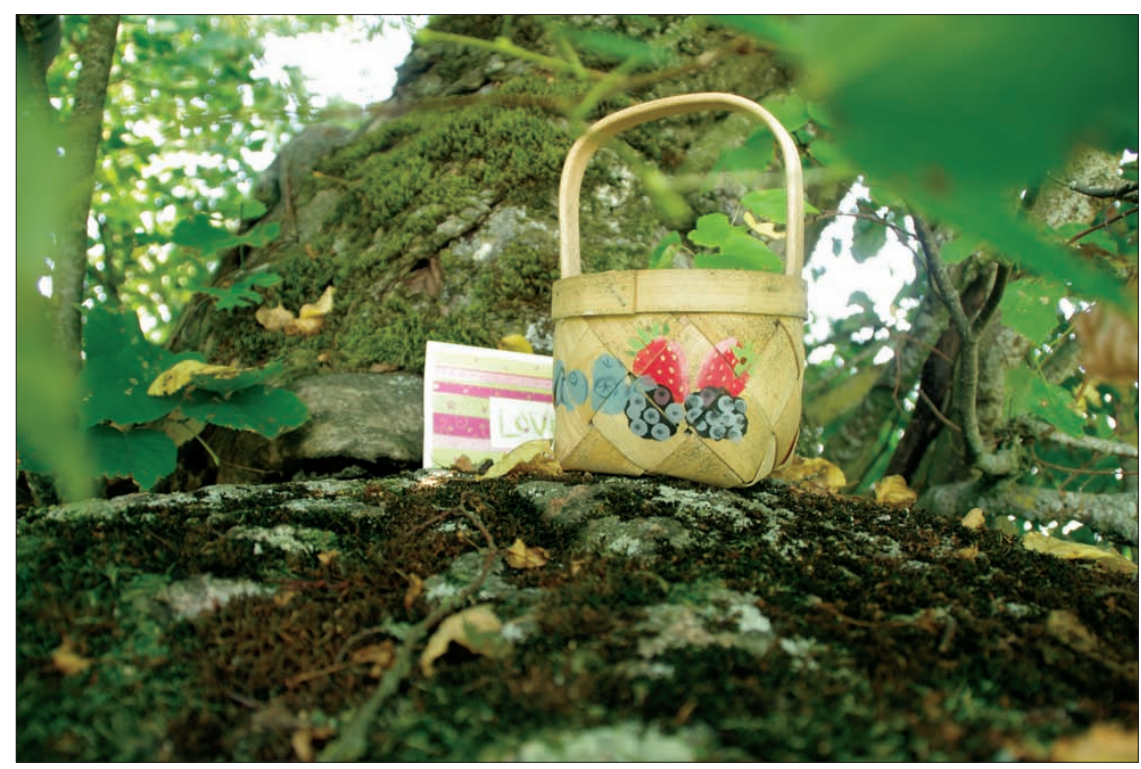

Figure 15. A basket with apples and a postcard at Sipa. Photograph by T. Jonuks 2013. On the other side of the postcard, there is a love spell, reading:

We'll take yellow clay, my dear, and mould

two figures - you and me. Now press them

back into a shapeless clump and mould again-you and me!

Half of you is me and half of me is you! 
Figure 16. Female stockings hanging in Mäesuitsu sacred tree, Võnnu. Photograph by T. Jonuks 2016.
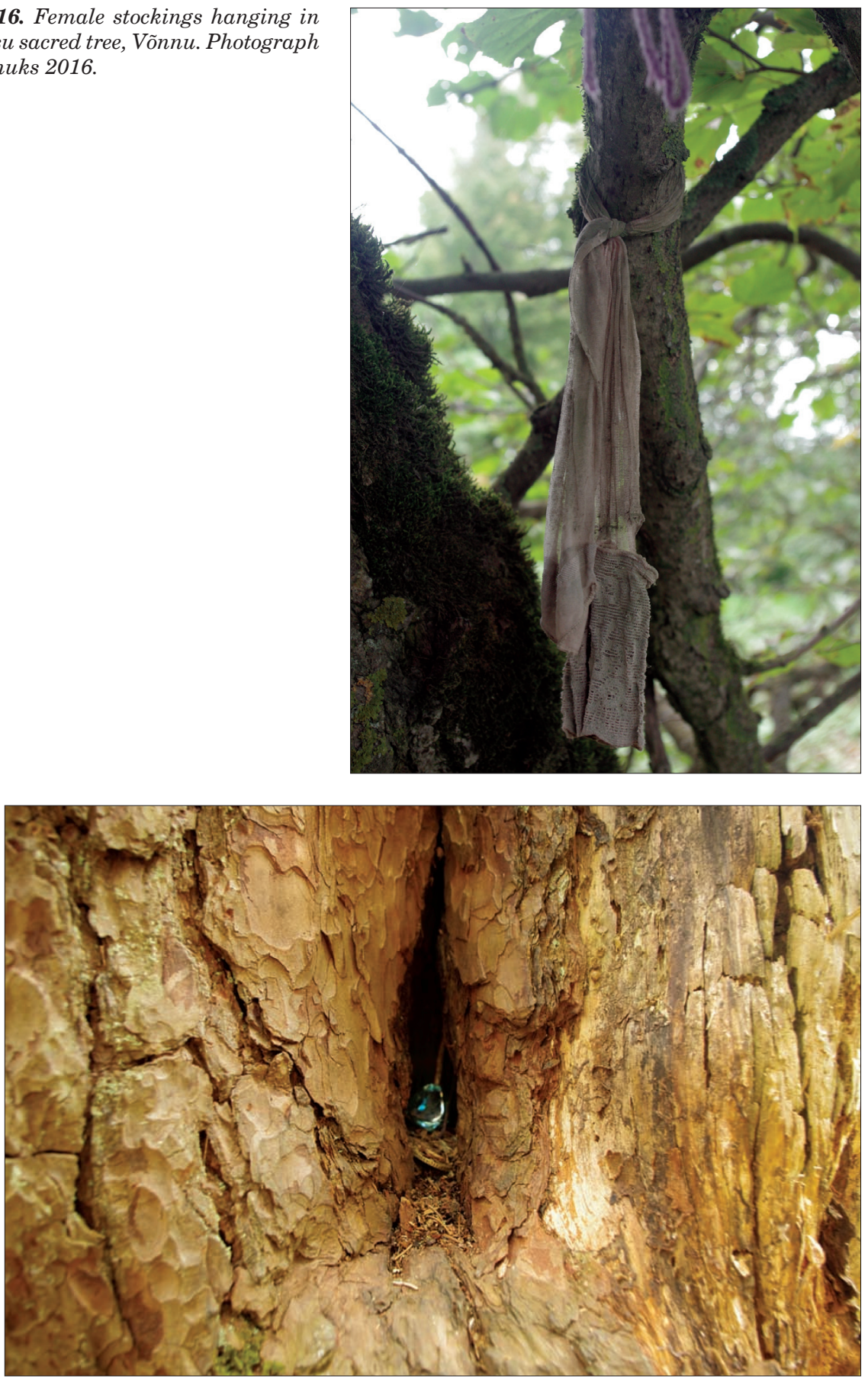

Figure 17. A heart-shaped pendant and coins at Tim's pine. Photograph by T. Jonuks 2017. 


\section{Magic, esotericisms, syncretism, and Christianity}

Sacred places under study often contained material references to magical and esoteric worldviews. It is interesting to note that in our study, all examples come from Estonia and none were recorded in Finland. For instance, we recorded round pendants with kabbalah signs hanging on tree branches at several sites in Estonia (Fig. 18). These are the objects most clearly associated with other belief systems than the local folk culture. A Celtic cross-shaped candlestick dominated by a bat-shaped creature at the Sipa linden tree might refer to Gothic or Satanist traditions, again alien to the traditional culture in Estonia but apparently linked with sacred places.

The most widespread non-traditional deposits are different crystals and gemstones. The inspiration to use gemstones as deposits most likely comes from very different sources, among others contemporary esotericism, New Age, contemporary Paganisms, and other spiritual movements where supernatural power and energy are ascribed to different kinds of crystals (e.g. Melton 2013). Angel figurines might also indicate visits by members of various contemporary spiritual movements (Fig. 19). Despite angels being associated directly with Christianity, they are also important in New Age and neo-spirituality, where angels represent protective spirits (Uibu 2014).

This kind of intertwining of very different spiritual movements could also be seen in the so-called Ojo de Dios (God's eye) decorations found at several places (Fig. 20). These woven stick objects are traditionally made in Mexico and Bolivia and placed on altars. Originally Ojo de Dios has symbolised the ability to see unseen things, with its four points representing earth, air, water, and fire. Nowadays Christians throughout the world have popularised this craft as a symbol of the one and only God. However, similar motifs have been found around the world, even in Finland and Estonia, where they have been used in folk culture as decorations on maypoles in Finland and at Christmas, New Year, and on other festive occasions in Estonia (Potts 1982: 60-67). These objects are also introduced into Pagan and spiritual practices, which is the most likely background for their appearance at Estonian sacred places. The importance of Central and South American spiritual practices in contemporary Baltic Paganisms is also known from Lithuania (Aleknaite 2017).

Several examples referring to Christianity were also recorded at sacred places. These included Russian Orthodox icons hanging on branches at the Pärnamäe sacred grove (Harju County, Estonia), as well as individual neckcrosses at several other sites (Fig. 21). For instance, Äikäs has recorded similar examples from Sámi offering sites in northern Finland, where a silver cross pendant and a tract with the title "Jesus Christ your Saviour" had been left on 
offering stones. Whereas the latter could be seen as an attempt to Christianise a 'pagan' sacred place, other interpretations for these and the Christian objects at Estonian sacred places could include leaving behind the Christian faith or the representation of a syncretic faith. Pärnamäe provides the most obvious example of a multifaceted audience using sacred places. Its location close to the capital makes this place attractive and easily accessible also to people living in the urban centre, who are interested in spiritual practices.
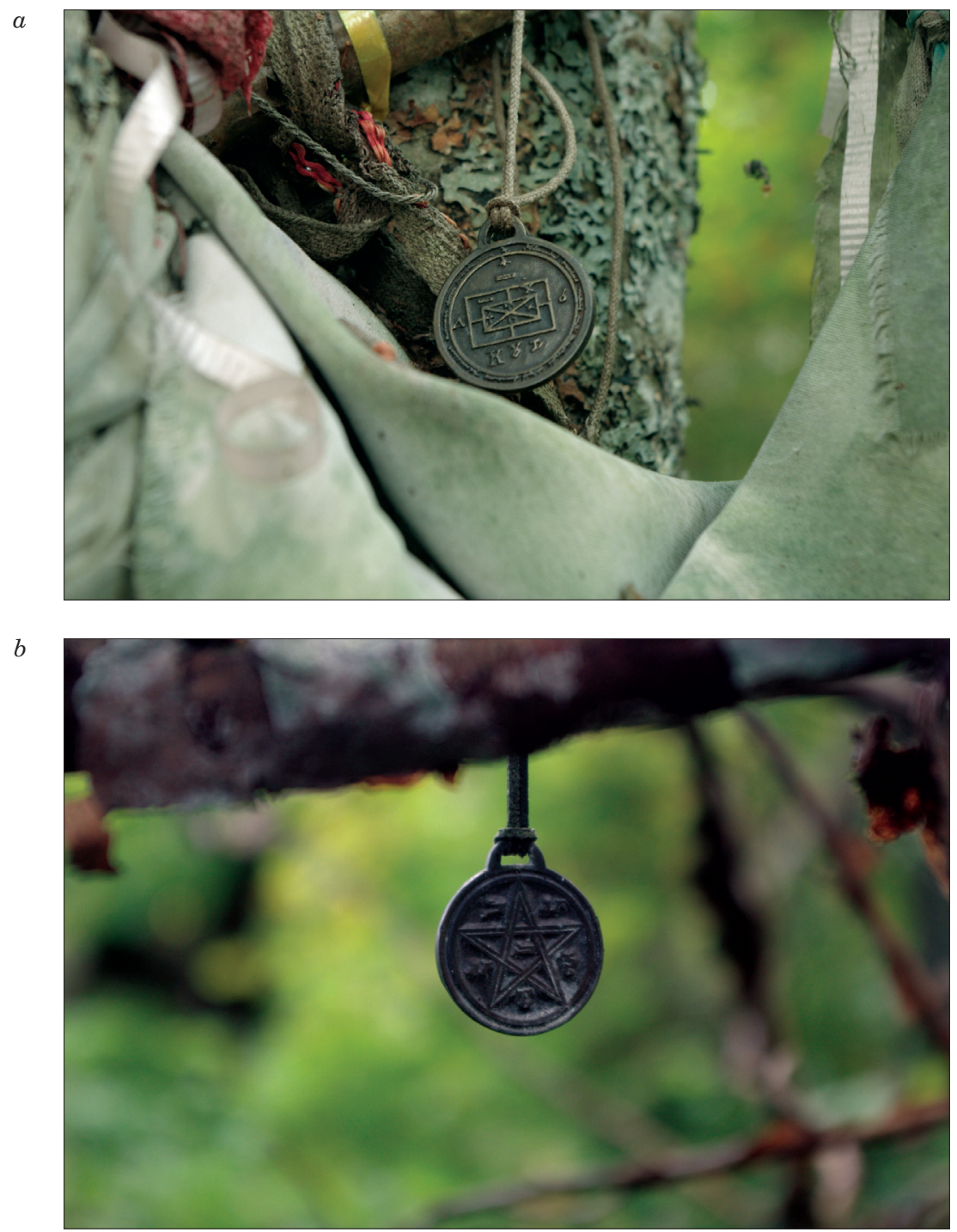

Figure 18. Kabbalah pendants at Pärnamäe (a) and Kiigeoru (b) sacred groves. Photographs by T. Jonuks 2016. 


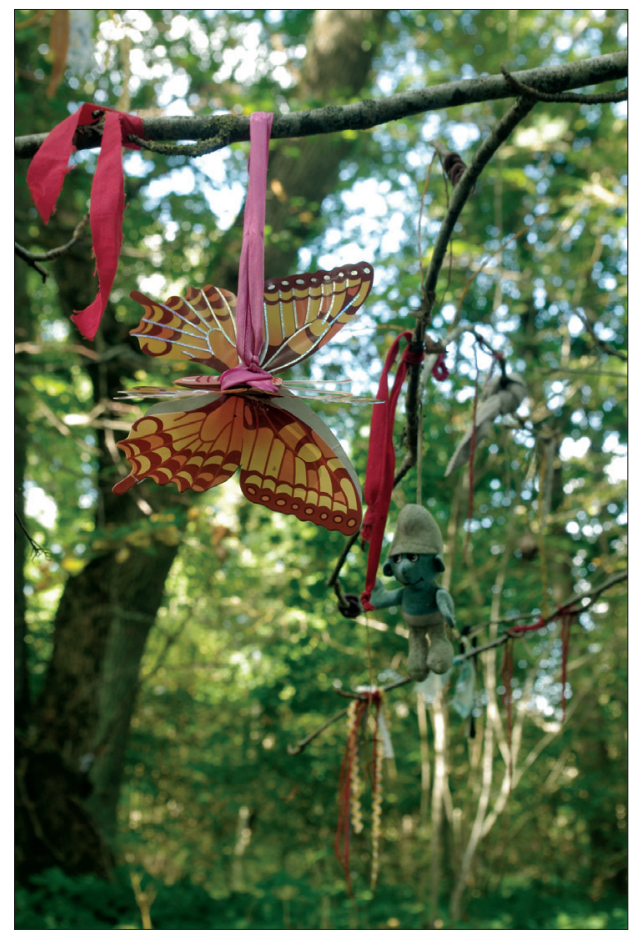

Figure 19. Butterflies, Smurfs, and angels at Pärnamäe. Photographs by

T. Jonuks 2016.

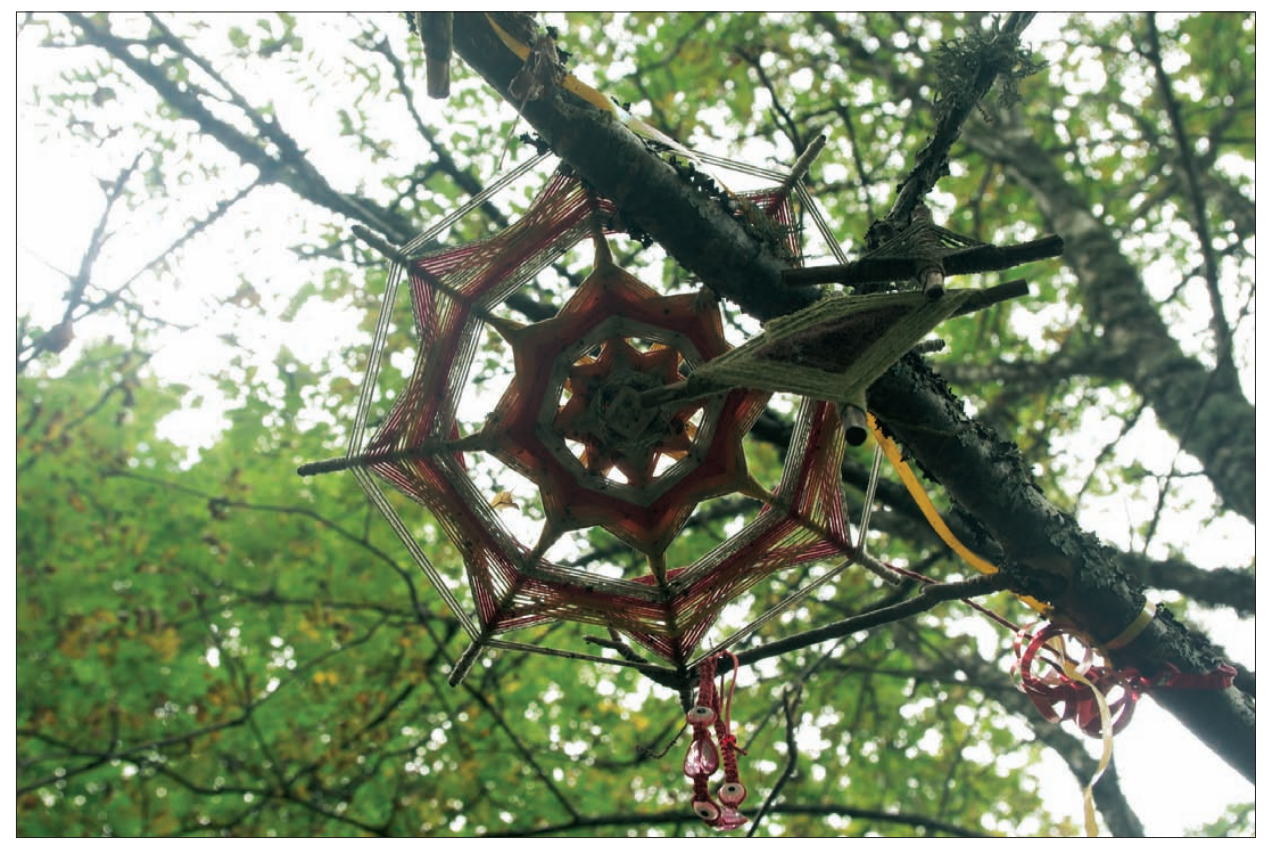

Figure 20. Ojos de dios at Pärnamäe. Photograph by T. Jonuks 2016. 
$a$

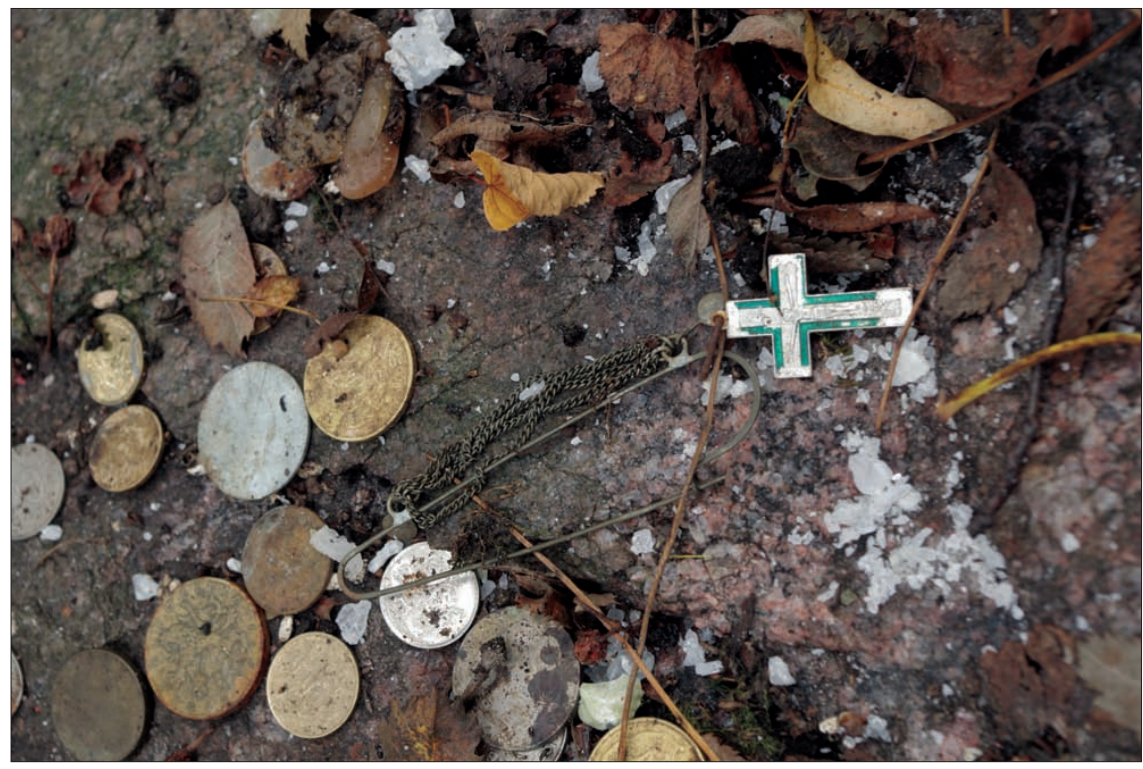

$b$

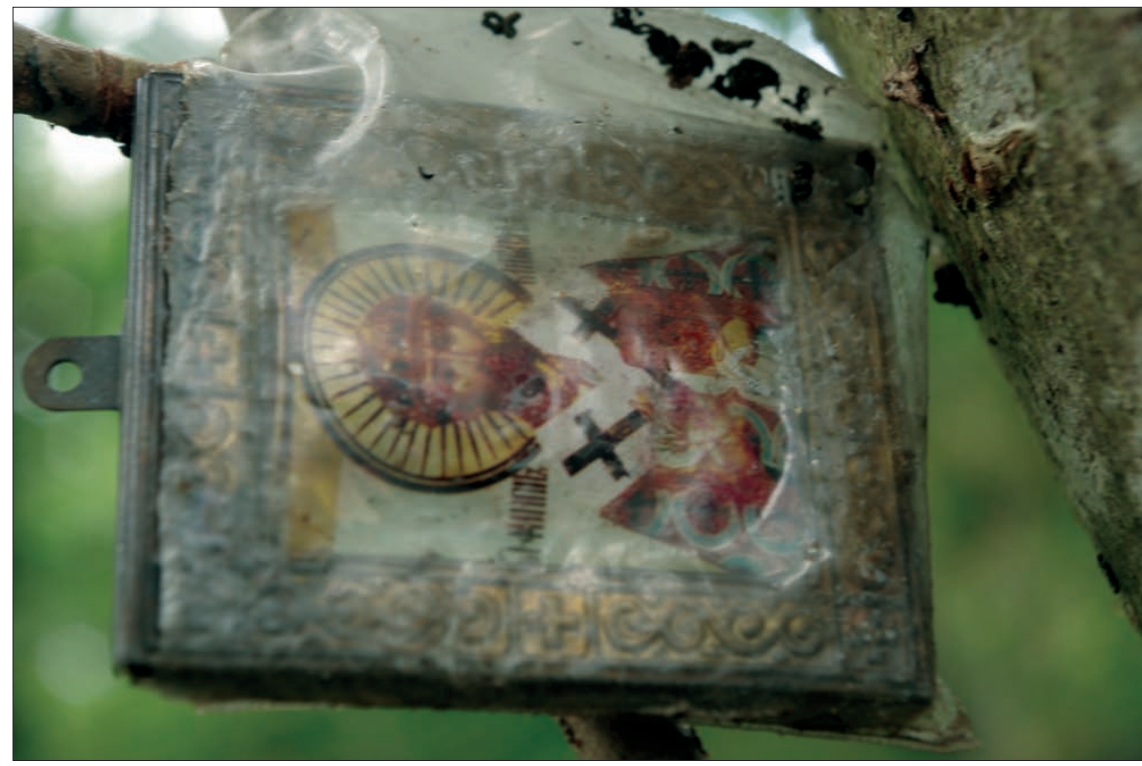

Figure 21. A neck cross (a) and icon in a plastic bag (b) at Pärnamäe. Photograph by T. Jonuks 2016. 


\section{SITE BIOGRAPHIES - SAME OBJECTS, DIFFERENT LIVES}

We have selected two trees to present two different site biographies resulting in different levels of deposit accumulation. At Tim's pine in Hämeenkyrö, Finland, the deposits are hardly visible when one first encounters the tree, whereas at most of the Estonian sites ribbons, rags, and other deposits cover almost every inch of the tree. The practice is most clearly visible at Pärnamäe, which is close to Tallinn and thus easily accessible to visitors from the town (Fig. 7).

Tim's pine is an example of how meaning attached to sacred places can change with time (Fig. 3). In folk tradition, it was connected to healing toothaches. It was believed that when an aching tooth was pressed with a stick and the stick was left in this pine, the pain would also be left there. Even as late as in the 1930s, coins were offered into the cracks of the tree. There is also a folk tradition of leaving bear skulls and ribbons at the tree (for more details, see Kovalainen \& Seppo 2006). Later, these beliefs were forgotten, and in the 1990s the pine was presented to local schoolchildren as just an old pine. At present, offerings have once again been made to the pine. The hiisi project by the Taivaannaula organisation has probably raised awareness of this place. Contemporary deposits include coins, a glass heart, and nails hammered into the tree. The latter example is exceptional in contemporary Pagan tradition, where the protection of sacred places is emphasised together with a ban on harming anything at a sacred place. However, according to oral tradition, nails have also been hammered into Estonian sacred trees. The most famous example is a linden tree from Ülendi, Hiiumaa Island, western Estonia. According to folklore (E 8 o 11, 81 (173)), rags and ribbons were attached to the tree with nails, some of which ended up in the archaeology collection of Tallinn University (AI 2679). But Tim's pine also has cut marks indicating the removal of some pieces of wood. Considering the history of the tree being used for medical purposes, the removed wood could also have been used for something similar.

The site is easily accessible to both contemporary Pagans and other people. It is mentioned on the Retkipaikka (Outing place) website, which offers articles related to natural places to visit. The website provides background information, folklore, coordinates, and a map of Tim's pine ${ }^{7}$. The article was published on 13 May 2016 and could have encouraged visitors to see the site since then. Also, Taivaannaula organised a trip to Tim's pine on the day of the hiis (hiisienpäivä) in $2017 .{ }^{8}$ Regardless of the long history of the place and different people visiting the site, the deposits left at the tree are still not easily noticeable. During our field trip, we walked around the tree a couple of times before we noticed the deposits in the cracks of the bark.

A significantly different life history is represented by a linden tree at Ilumäe, northern Estonia (Fig. 5). This is also a lone tree, which grows at the edge of 
a buried cliff on a visually spectacular site. The location is near a historical road connecting the local manor and church, and thus most local traffic during more than a century passed by this tree. In the early twentieth century, the tree stood alone and was thus even a better landmark than now, as it is currently partly shadowed by other trees. There are a few records in the folklore archives referring to the tree as sacred (see, e.g., www.folklore.ee/radar). A new life for the tree began in the 1970s, when this area was included in the Lahemaa National Park. The tree became a touristic attraction, and it was acknowledged and known (see in more detail Kindel 2005: 62). During this time, however, it was only a touristic destination and no deposits were left. There are several detailed descriptions and photographs from the 1970s and 1980s (e.g. Joonuks 1990) that do not mention any deposits. In 2000 Tõnno Jonuks communicated with an elderly man (born in 1910) from the nearby village of Muike, who confirmed that during his lifetime he had not witnessed any deposits or offerings. However, Ahto Kaasik, a former leader of Maavalla Koda, argued to have seen individual ribbons on the tree already in 1989 or 1990 (personal communication,

A. Kaasik 2017).

The piling of rags and ribbons started in the early 2000s and has been a continuous tradition ever since. Meelika Kindel associates this start with a local folk festival in 2003 as a protest against cutting down forests and destroying nature (Kindel 2005: 81 and references therein). The fact that such a public call was made definitely had a major effect, although the tradition of tying rags and ribbons on trees was known at this place already earlier. Since then, the tree has been not only a touristic destination but also an increasingly important active sacred place. Tourist groups also participate in leaving rags and other deposits. It is interesting to note that some guides include the tree in the tour and others have stopped there only because the group requested it, as they personally do not approve of such massive visits and piling of deposits (see in more detail Kindel 2005: 81ff.).

Thus, these two examples demonstrate well how similar physical objects can acquire different biographies due to the activity of contemporary groups. Tim's pine has been left outside of major touristic routes even though it is mentioned as an attraction for nature tourists, and it has therefore been preserved in its original condition. Some deposits (like hammered nails) seem to be older, whereas the coins and glass heart represent contemporary traditions. The Ilumäe linden, on the other hand, was included in touristic routes and thus became widely known. In the 1990s, contemporary Pagans added another layer of practice, which was again developed further by the guides of the national park and local enthusiasts. 


\section{CLEANING OF THE SITES}

As the number of deposits at sacred places increases, the question of what to do with the material has become critical (cf. Finn 1997). The effect of contemporary Pagan practices at sacred places may vary from piling offerings to fire and graffiti damage. The positions of contemporary Pagans on sacred places may vary from a preservation ethos similar to that of heritage authorities to "claiming individual divine inspiration for whatever practices seem appropriate at the time" (Wallis \& Blain 2003: 310).

The two most common strategies can be observed in Estonia and Finland leaving all the deposits as they are or removing the 'inappropriate' ones. The leaving of deposits is usually justified with two arguments: the authorities do not know how to handle the objects, or all deposits are seen as meaningful and are thus left at the site. Removal has to be thoroughly argued and is thus also more open to analysis. There has been a tendency in contemporary Pagan movements to welcome all kinds of deposits but to restrict the use of inorganic materials. Some incidents in Estonia, where Pagan organisations interfere forcefully to guide traditions into the 'right' direction, illustrate this tendency most clearly. In several areas, sacred places have been cleaned of inappropriate deposits (like plastic bags and other synthetic materials), but these are usually not public events. The most well-known is the case at the Ilumäe sacred tree in April 2009, which was publicised in local news (see Virumaa 2009). As the cleaning was organised by Maavalla Koda, it also demonstrates their attitudes and beliefs. As all the deposits were considered as remains of meaningful acts, a ritual was conducted at first to protect the participants and ask the tree for permission to remove plastic bags and ribbons (personal communication, A. Kaasik 2017). The plastic deposits were then cut off from the tree and recycled. Organic and 'traditional' deposits (e.g. coins) were left in place with the argument that they follow historical tradition or will decay in the course of time.

Similar cleaning actions have also been carried out in Finland, although they have not been public events. According to our informant from Karhun kansa, some members have, as a part of their private rituals, cleaned inorganic materials such as plastic bags and bottles from sacred places, but left coins, since they can be considered as offerings (personal communication, Kiiski 2017). Similar cleaning of sacred places has also been conducted in other countries either by heritage authorities or local communities. In some cases, the regulations may result in radical solutions. As contemporary deposits left at a sacred place were taken as an offence by the indigenous Pueblo Indians at Chaco Canyon in the US, the National Park Service closed off Casa Rinconada to the public at least partly (Finn 1997: 177). The photographs by artist Sara 
Hannant offer an interesting example of how removed deposits can gain a new meaning. She used cloths that were removed from a tree by a sacred well by the members of the Cornish Ancient Sites Protection Network to create artwork of the removed objects and "re-animated these discarded cloths using natural forces in keeping with the folk magic, symbolised by the four elements of air, earth, fire, and water". ${ }^{9}$

Thus, these cases form a good example of how Pagan or local communities share the responsibility for behaviour at sacred places with legal authorities. However, broader discussion is often missing, and, depending on the interests of different sides, the purposes for cleaning the sites may also differ. National heritage authorities usually do not share the beliefs of Pagan groups and are concerned about preserving the site rather than keeping the place alive. A wellknown case is Stonehenge, where English Heritage banned solstice parties because partying was perceived as secular and non-spiritual and therefore not appropriate for a sacred place (Wallis \& Blain 2003). Members of the Estonian Maavalla Koda have published multiple articles in local newspapers to emphasise the unfitness of inorganic materials as deposits, and it currently seems that the amount of plastic objects is decreasing at most sites. As this issue is rather new in southern Finland and Estonia, the corresponding discussion mainly concerns northern Finland, where regulations on restricting the use of the sacred places of indigenous Sámi have been discussed and employed for decades. Especially in the case of the sacred Ukonsaari island, touristic infrastructure, including platforms and steps to the top of the steep island, as well as the fact that people are landing onto the island, are seen as inappropriate. Eventually all this leads to the issue of different interested parties claiming ownership of the sacred place and having the authority to make rules following their interests and ethical and professional values. This, however, is a subject for more thorough discussion in future studies.

\section{DISCUSSION: MINGLING IDENTITIES AND PROVING AUTHENTICITIES}

In this article, we have discussed how different groups interact with sacred places by leaving a variety of different offerings and deposits. By describing the process like this, it appears to be a rather peaceful development where all kinds of different beliefs entwine into a 'fuzzy spirituality' (Uibu 2016). However, hidden tensions can be revealed, most clearly in cases where sites are cleaned of inappropriate deposits, but somewhat contradictory deposits are left. This illustrates well a potential conflict of interests between different parties that claim some activities to be inappropriate. 
As stated above, some contemporary Pagan movements, especially Maausulised in Estonia, feel that they are directly continuing a ritual tradition dating from time immemorial, often identified as prehistoric times. Thus, they describe themselves as indigenous groups in Estonia. ${ }^{10}$ We have used the concept of 'native' (in inverted commas) to make a distinction with the word 'indigenous' as referred to in the ILO Convention No. 169. It is not within the scope of this article to tackle the questions of historical vs. perceived continuity of ritual traditions more closely (see, e.g., Harvey 1997; Wallis 2003). However, as 'native' members of Maausulised have taken an active role in specifying the ways sacred places can be used and the concept of 'indigenous' is central to their discussion of the essence of maausk itself, this issue has to be discussed. Attaching objects to trees is a good example of this. As stated earlier, tying rags and ribbons to trees is an old tradition that contemporary Pagans have made visible again. In the Pagan rhetoric, the custom is claimed to be an old and unbroken tradition. However, there are no good historical examples known, and it currently seems that the tradition lapsed somewhat during the twentieth century. Thus, the Pagans are following an abstract tradition rather than a continuously practised custom. This is also well illustrated by the words of an anonymous member of Taivaannaula, who mentioned that the tradition of tying ribbons to trees is currently being introduced into Finland, although he simultaneously also considered it a historical tradition.

Such a discrepancy is explained by how the custom is perceived on different levels and by the attitude that a historical tradition that seems to have disappeared can be reintroduced without questioning its historical continuity. Similarly, while considering neo-shamans and their interpretations of the past, Robert J. Wallis (2001: 226) states that "neo-shamans are reconstructing the past in and for the present, for personal and communal spiritual empowerment. The authenticity of the reconstruction is not the main issue, merely its relevance and pragmatism for the practitioners". As a result, occasional visitors follow the example of what is left at sacred places by Pagans and re-interpret what they see. Thus, other objects are also attached to the tree, such as plastic ribbons, reflectors, and Christmas decorations. These could be seen as a sign of ritual creativity where the old tradition and new meanings are intertwined. People can just leave things that they happen to have with them, such as reflectors, or the objects that might have a special meaning for them, as might be the case with pendants carrying different symbols. After this new involvement with sacred places, contemporary Pagans have again taken the lead in defining how to use these places by removing inorganic deposits.

In Estonia, sacred places are often associated with the members of Maausulised, who have in many cases started the traditions that other users follow and 
mimic. This results partly from the high activity of this Pagan movement in publishing popular articles in local newspapers and journals (according to their own words, more than 700 newspaper articles and interviews were published from 2008 to 2012$)^{11}$ and thus shaping the general view of sacred places. In these discussions so far, sacred places are closely associated with Estonian history and national identity. Both currently dominating organisations, Maavalla Koda and Taivaannaula, distance themselves in public from religious movements and emphasise their cultural activities, which helps to understand their activity in taking care of cultural heritage. Especially in Estonia, therefore, the act of visiting a sacred place and leaving deposits has moved from the religious or spiritual sphere to the area of cultural heritage. Most visitors do not associate this practice with a Pagan movement but see it as an expression of their national feelings. This is most probably the reason why sacred places are so popular in Estonia, why they are often visited by people who do not identify themselves as Pagans, and why there is no religious conflict when Christians and pastors support such sacred places. Thus, an exclusive 'native' use of sacred places has become a manifestation of national identity.

A variety of blended worldviews can be recognised among people who visit sacred places. For example, angel figures and icons left at sacred places can manifest the syncretic worldview of the people visiting the sites. In some cases, we can see direct references to esoteric and magical practices like kabbalah pendants, angels, or rock crystals, which indicate the entwining of local Pagan and universal esoteric traditions. Kathryn Rountree has stated that individuals can combine Christian and Pagan belief elements in their identity, saying: "Some individuals now claim dual Christian and Pagan identities or hyphenated identities, combining elements of Christian and Pagan ritual, hence 'ChristoPagan' and 'Christian Witch"' (Rountree 2014: 82). Tiina Äikäs made similar observations when she interviewed the participants of the Isogaisa shamanistic festival in Norway (Äikäs et al. 2018). For example, some of the festival attendees identified themselves as both Catholic and shaman.

Even though Christianity and Paganism might seem like strange bedfellows, there are examples of pastors protecting old sacred places and even using them for church services, as has been the case in Rovaniemi, northern Finland. Local congregation have taken an old sacred place, Somosen kirkko (The church of Somonen), into use and built a bell tower, altar, and benches there (Äikäs 2015: 202). This kind of activity can be seen as an attempt by the church to show respect towards the old sacred places. Historical sources often give the impression that Christian authorities opposed the veneration of natural objects in Estonia and Finland, considering it as paganism (see, e.g., Jonuks 2009). However, due to the blurring borders of different religions nowadays, such 
a sharp contrast no longer exists. The pastor of the Jüri Lutheran congregation in northern Estonia has been proactive in protecting a hill at Tõdva as an alleged sacred place. The main arguments for protecting the hill were related to the status of this sacred place as a symbol of national identity and its value as both natural and local historical heritage. As a result, different religious backgrounds did not cause any conflicts, as this sacred place was not perceived as a Pagan place but as part of Estonian cultural heritage. Christian crosses and icons at sacred places therefore do not necessarily indicate opposition but can be viewed as deposits with multiple meanings, similar to coins, ribbons, and other common items.

In this article, we have emphasised a distinction between contemporary Pagan offerings and touristic deposits. The difference between these two is, nevertheless, far from clear. Especially in northern Finland, shamanistic performances, even though ethically problematic from an indigenous perspective, are often organised for tourists (Äikäs 2015: 169-172), who may respond to the spirituality behind the event with varying intensity. In Rapola, Finland, silent meditation walks are organised, even though the advertisement does not mention any connection with the cup-marked stones in the area. Also the rich collection of Soviet coins from the Helme spring in Estonia is most likely associated with touristic activities, as the spring is located near the ruins of a medieval castle along a major road. Still, it would be erroneous to attempt to draw sharp divisions, as spiritual purposes may intertwine with touristic activities, thus blurring both sides. However, the touristic effect on the formation of deposits is obvious, as material objects are left not only at sacred places, as is traditional, but also in public pools, fountains, or at trees.

Coins, foodstuffs, and rags, as popularised by Pagan movements, dominate the offerings at sacred places. In addition to these, visitors have also reinterpreted what they see at the site or what they have learned from newspaper articles or books, which results in a wide variety of very different objects deposited. They consist of all kinds of ordinary and practical bindable objects: reflectors, plastic bags, and hair bands. Also simple woven items, like Ojo de Dios, simple representations of angels, and similar objects, are quite numerous. However, these items demand more effort than simply leaving a coin and thus reflect a more personal visit and purpose. Deposits could be divided into three groups: those connected with old traditions and revitalising old folk beliefs, those that seem to stem from ritual creativity and build new ways of communication with sacred places, and finally deposits that are left for touristic purposes by copying the already existing phenomena. 


\section{CONCLUSIONS}

We have documented a large variety of very different deposits at places considered sacred in oral lore. Despite the similarities between Finland and Estonia in the areas of folk culture, distant history, and approaches to nature, deposits left at sacred places are significantly different in the two countries. While deposits in Finland seem to represent either traditional food offerings or coins, deposits left in Estonia are very diverse, representing the versatile audience using the places. Sacred places are not perceived as related only to a Pagan belief system but as a sign of Estonian national identity and cultural heritage.

The situation in Finland, however, is very different. Even though there are several contemporary Pagan movements in Finland, they do not have an overarching influence on the general public, unlike in Estonia. This is probably also the reason why the selection of sacred places that are actively used for depositions is significantly smaller than in Estonia. This is even more remarkable, as according to the only comparative study of Estonian and Finnish sacred places (hiis) by Mauno Koski $(1967,1970)$, the number of such sites is more or less equal in both countries.

One reason for the lack of finds in Finland is that sacred places are mainly used by individuals, families, or small groups, and their location is not shared with others. This was suggested by the informant from Lehto ry, who also mentioned that calendar rituals are practised at different places around Finland each year, so that no particular place is chosen as a continuous ritual arena (personal communication, Krabbe, 2017). People can visit sacred places, but as the rituals are not organised, they do not leave easily recognisable marks like the more concentrated visits in Estonia. The same claim has also been made concerning Estonia, where the main categories of sacred places include personal or family-based and communal sites (Kaasik 2007: 42), but the first are difficult to access and study.

The reasons behind why different groups leave deposits at sacred places and how the places are selected still requires further study and will form the future direction of our research.

\section{ACKNOWLEDGEMENTS}

We wish to thank our informants who shared their knowledge on the use of sacred places and visited some of the places with us. We are also grateful to our colleagues, Professor Helena Ruotsala and Doctor Sonja Hukantaival, who visited Virnamäki in Turku more often than we were able to and sent us photographs. Our thanks are also due to the anonymous reviewers whose 
comments made this article better. Tõnno Jonuks conducted this study under an institutional grant by the Estonian Ministry of Sciences (IUT 22-5) and the Centre of Excellence in Estonian Studies (CEES), and Tiina Äikäs conducted this work under funding from the Academy of Finland (294626).

\section{NOTES}

1 We recognize that the use of the term pagan can be problematic, since it has had negative connotations in the sense of a despicable person who did not practise the main religion. The term has nevertheless been established in research literature and is also used as an emic category by some contemporary Pagans (see, e.g., Sjöblom 2000). In this study, the concept pagan is therefore understood merely as an academic term with no qualitative implications.

${ }^{2}$ National Heritage Board of Estonia; see https://www.muinsuskaitseamet.ee/et/ ajaloolised-ja-looduslikud-puhapaigad, last accessed on 18 January 2019.

3 See, e.g., https://www.maavald.ee/maausk/maausust/maausust, last accessed on 18 January 2019.

4 See http://www.karhunkansa.fi/about_pages/view/14, last accessed on 18 January 2019 (translation by the authors).

5 Äikäs has also documented contemporary offerings at Sámi sacred places (Äikäs 2015; Äikäs \& Spangen 2016; Äikäs et al. 2018). This abundant material is left out of this study or only used as comparative material, since these sacred places belong to a different cultural tradition and also the questions of their contemporary use relate mainly to different user groups than those at sacred places in southern Finland.

6 See http://www.taivaannaula.org/perinne/hiisi/, last accessed on 18 January 2019.

7 See https://retkipaikka.fi/timin-manty-hammassarkyisten-auttaja/, last accessed on 21 January 2019.

8 See http://www.taivaannaula.org/2018/08/08/turussa-kuullaan-suomen-ja-viron-pyhistapaikoista/, last accessed on 21 January 2019.

9 See https://www.sarahannant.com/portfolio/numinous/, last accessed on 21 January 2019 .

${ }^{10}$ See, e.g., https://www.maavald.ee/koda/taarausuliste-ja-maausuliste-maavalla-koda/65tutvustus, last accessed on 21 January 2019.

${ }^{11}$ See http://hiis.ee/files/Koondaruanne_2008_2012.pdf, last accessed on 21 January 2019.

\section{ARCHIVAL SOURCES}

AI - Archaeology collection at Tallinn University

E - Folklore collection of Matthias Johann Eisen at the Estonian Literary Museum

$\mathrm{H}$ - Folklore collection of Jakob Hurt at the Estonian Literary Museum 


\section{REFERENCES}

Äikäs, Tiina 2015. From Boulders to Fells: Sacred Places in the Sámi Ritual Landscape. Transl. by Sarianna Silvonen. Monographs of the Archaeological Society of Finland 5. Available at http://www.sarks.fi/masf/masf_5/masf_5.html, last accessed on 22 January 2019.

Äikäs, Tiina \& Spangen, Marte 2016. New Users and Changing Traditions: (Re)defining Sami Offering Sites. European Journal of Archaeology, Vol. 19, No. 1, pp. 95-121. https://doi.org/10.1179/1461957115Y.0000000009.

Äikäs, Tiina \& Fonneland, Trude \& Thomas, Suzie \& Perttola, Wesa \& Kraft, Siv Ellen 2018. "Traces of Our Ancient Religion": Meaning-Making and Shamanism at Sámi Offering Places and at the Isogaisa Festival, Northern Norway. In: Jutta Leskovar \& Raimund Karl (eds.) Archaeological Sites as Space for Modern Spiritual Practice. Newcastle upon Tyne: Cambridge Scholars, pp. 1-20.

Aleknaitè, Eglè 2017. Neoshamanic Interpretations of a Local Indo-European Religious Tradition. Nova Religio: The Journal of Alternative and Emergent Religions, Vol. 20, No. 3, pp. 13-35. https://doi.org/10.1525/nr.2017.20.3.13.

Arola, Iiro 2011. Suomenuskoiset erottautuvat muista uuspakanoista. [Finns Differ from Other Neopagans.] teologia.fi, 21 January. Available at https://www. teologia.fi/54-opinnaytteet/pro-gradut/624-suomenuskoiset-erottautuvat-muistauuspakanoista, last accessed on 22 January 2019.

Arukask, Madis 2017. The Personal Rituals of the Finnic Peoples with Forest Trees (On the Basis of Two Examples). Anthropology \& Archaeology of Eurasia, Vol. 56, No. 1-2, pp. 167-185. https://doi.org/10.1080/10611959.2017.1352307.

Busch, Nikolai 1937. Studien zur baltischen Vorgeschichte I. Abhandlung der HerderGesellschaft und des Herder-Instituts zu Riga 6/1. Rīga: Plates.

Economist 2017 = Estonia is Trying to Convert the EU to Its Digital Creed. The Economist, 6 July. Available at https://www.economist.com/europe/2017/07/06/estonia-istrying-to-convert-the-eu-to-its-digital-creed, last accessed on 16 January 2019.

Fennell, Julie \& Wildman-Hanlon, Laura A. 2017. The Children of Converts: Beyond the First Generation of Contemporary Pagans. Social Compass, Vol. 64, No. 2, pp. 288-306. https://doi.org/10.1177/0037768617704165.

Finn, Christine 1997. 'Leaving More Than Footprints': Modern Votive Offerings at Chaco Canyon Prehistoric Site. Antiquity, Vol. 71, No. 271, pp. 169-178. https://doi. org/10.1017/S0003598X00084659.

Harvey, Graham 1997. Listening People, Speaking Earth: Contemporary Paganism. London: Hurst Publishers.

Heino, Harri 1997. Mihin Suomi tänään uskoo. [What Finland Believes Today.] Helsinki: WSOY.

Hiiemäe, Mall 1997. Nelikümmend lindu Eesti rahvausundis IV. [Forty Birds in Estonian Folk Religion]. Mäetagused, Vol. 5, pp. 7-22. http://dx.doi.org/10.7592/MT1997.05. linnud4.

Hiiemäe, Reet 2017. Magic in Soviet and Post-Soviet Estonia. In: Alexandra Cotofana \& James Nyce (eds.) Religion and Magic in Socialist and Post-Socialist Contexts II: Baltic, Eastern European, and Post-USSR Case Studies. Stuttgart: Ibidem Verlag, pp. 135-160. 
Hjelm, Titus 2006. Between Satan and Harry Potter: Legitimating Wicca in Finland. Journal of Contemporary Religion, Vol. 21, No. 1, pp. 33-48. https://doi. org/10.1080/13537900500381732.

Hjelm, Titus 2016. Paganism in Finland. In: Henrik Bogdan \& Olav Hammer (eds.) Western Esotericism in Scandinavia. Leiden: Brill, pp. 360-366. https://doi. org/10.1163/9789004325968_047.

Houlbrook, Ceri 2016. Saints, Poets, and Rubber Ducks: Crafting the Sacred at St Nectan's Glen. Folklore, Vol. 127, No. 3, pp. 344-361. https://doi.org/10.1080 /0015587X.2016.1197593.

Ivakhiv, Adrian 2005. In Search of Deeper Identities: Neopaganism and "Native Faith" in Contemporary Ukraine. Nova Religio: The Journal of Alternative and Emergent Religions, Vol. 8, No. 3, pp. 7-38. http://dx.doi.org/10.1525/nr.2005.8.3.7.

Jonuks, Tõnno 2009. Hiis Sites in the Research History of Estonian Sacred Places. Folklore: Electronic Journal of Folklore, Vol. 42, pp. 23-44. http://dx.doi. org/10.7592/FEJF2009.42.jonuks.

Jonuks, Tõnno 2013. Der estnische Nationalismus und sein Konzept der prähistorischen Religion: Die Nation als Gestalterin des Religionsbildes. Forschungen zur baltischen Geschichte, Vol. 8, pp. 145-164.

Jonuks, Tõnno 2018. New Trends in the Study of Religion in Estonia: Contemplations in the Grey Zone between Religion and Science. In: Ekaterina Anastasova \& Mare Kõiva (eds.) Balkan and Balticum: Current Studies in the Postsocialist Space. Sator 18. Tartu: ELM Scholarly Press, pp. 161-182. https://doi.org/10.7592/ Sator.2017.18.08.

Jonuks, Tõnno \& Friedenthal, Meelis \& Haak, Arvi 2010. Värtnakeder, talisman või nõiaese: märkidega kiviketas Viljandimaalt Rattama talust. [A Spindle Whorl, a Talisman or a Witchcraft Object: A Lithic Disc with Symbols from Rattama Farm, Viljandi County.] In: Ülle Tamla (ed.) Ilusad asjad: Tähelepanuväärseid leide Eesti arheoloogiakogudest. Muinasaja teadus 21. Tallinn: Tallinna Ülikooli Ajaloo Instituut, pp. 269-286.

Jonuks, Tõnno \& Oras, Ester \& Veldi, Martti 2018. Mix and Match, Old and New: Material Remains of Religious Practices by Estonian Pagans. In: Jutta Leskovar \& Raimund Karl (eds.) Archaeological Sites as Space for Modern Spiritual Practice. Newcastle upon Tyne: Cambridge Scholars, pp. 90-109.

Joonuks, Helmut 1990. Ilumäe pärn. [Ilumäe Lime Tree.] Eesti Loodus, No. 3, p. 179.

Kaasik, Ahto 2007. Ajaloolised looduslikud pühapaigad: Väärtused looduse ja kultuuri piirimail. [Historical Natural Sanctuaries: Values on the Borderland between Nature and Culture.] In: Heiki Valk \& Ahto Kaasik (eds.) Looduslikud pühapaigad: Väärtused ja kaitse. Õpetatud Eesti Seltsi Toimetised 36, pp. 23-74. Available at https://www.maavald.ee/images/failid/hiiekogumik.pdf, last accessed on 23 January 2019.

Kindel, Melika 2005. Vaateid kohapärimuse väärtustamisele lähtuvalt Lahemaa turismisituatsioonist. [Evaluation of Local Tradition: Aspects of Tourism Situation in Lahemaa National Park.] Unpublished MA thesis, University of Tartu, Estonia. Available at http://dspace.ut.ee/bitstream/handle/10062/986/ kindel.pdf?sequence=5, last accessed on 23 January 2019. 
Koski, Mauno 1967. Itämerensuomalaisten kielten hiisi-sanue: Semanttinen tutkimus I. [The Word hiis in Baltic-Finnic Languages: Semantic Study I.] Turun yliopiston julkaisuja: Sarja C. Scripta lingua fennica edita. Turku: Turun yliopisto.

Koski, Mauno 1970. Itämerensuomalaisten kielten hiisi-sanue: Semanttinen tutkimus II. [The Word hiis in Baltic-Finnic Languages: Semantic Study II.] Turun yliopiston julkaisuja: Sarja C. Scripta lingua fennica edita. Turku: Turun yliopisto.

Kovalainen, Ritva \& Seppo, Sanni 2006. Puiden kansa. [Tree People.] Helsinki: Hiilinielu Tuotanto.

Kuningas, Maire 2014. Ravimise ja nõidumise hõbepreesid. [Silver Brooches for Curing and Witchcraft.] Horisont, No. 1, pp. 6-7. Available at http://www.horisont.ee/ arhiiv-2014/Horisont-1-2014.pdf, last accessed on 23 January 2019.

Laid, Erik 1928. Proovikaevamisaruanne "Ülendi lõhmuspuu” juures. [Report of Test Excavation at "Ülendi Lime Tree".] Unpublished manuscript in the archives of the Institute of Archaeology and History, University of Tartu.

Laime, Sandis 2018. Offering Cave of the Livs in Latvia: From Sacred Place to Tourist Destination. In: J. Belaj \& M. Belaj \& S. Krznar \& T. S. Ivančan \& T. Tkalčec (eds.) Sacralization of Landscape and Sacred Places. Zbornik Instituta za Arheologiju, Vol. 10. Zagreb: Institut za arheologiju, pp. 383-392.

Melton, J. Gordon 2013. Revisionism in the New Age Movement: The Case of Healing with Crystals. In: Eileen Parker (ed.) Revisionism and Diversification in New Religious Movements. Farnham \& Burlington: Ashgate, pp. 201-211.

Mikita, Valdur 2008. Metsik lingvistika. [Wild Linguistics.] Tallinn: Grenader.

Mikita, Valdur 2013. Lingvistiline mets. [Linguistic Forest.] Tallinn: Grenader.

Mikita, Valdur 2015. Lindvistika ehk metsa see lingvistika. [To Hell with Linguistics.] N.p.: Välgi metsad.

Olearius, Adam 1669. The Voyages and Travels of the Ambassadors Sent by Frederick, Duke of Holstein, to the Great Duke of Muscovy, and the King of Persia. London: Printed for John Starkey, and Thomas Basset, at the Mitre near Temple-Barr, and at the George near St. Dunstans Church in Fleet-Street. Available at https:// archive.org/details/voyagestravellso00olea/page/n9, last accessed on 17 January 2019.

Potts, Albert M. 1982. The World's Eye. Kentucky: The University Press of Kentucky.

Religious Trends in Estonia 2014. Survey database created by Social and Market Research Company EMOR in January-February 2014 (unpublished). The questionnaire created by Lea Altnurme, University of Tartu.

Ringvee, Ringo 2017. Survival Strategies of New Religions in a Secular Consumer Society: A Case Study from Estonia. Nova Religio: The Journal of Alternative and Emergent Religions, Vol. 20, No. 3, pp. 57-73. https://doi.org/10.1525/nr.2017.20.3.57.

Rohtmets, Priit \& Ringvee, Ringo 2013. Religious Revival and the Political Activity of Religious Communities in Estonia during the Process of Liberation and the Collapse of the Soviet Union 1985-1991. Religion, State and Society, Vol. 41, No. 4, pp. 355-393. https://doi.org/10.1080/09637494.2013.855059.

Rountree, Kathryn 2014. Neo-Paganism, Native Faith and Indigenous Religion: A Case Study of Malta within the European Context. Social Anthropology, Vol. 22, No. 1, pp. 81-100. http://dx.doi.org/10.1111/1469-8676.12063.

Salminen, Timo 2008. Suomalais-ugrilaisuuden aate ja tiede: Suomalais-Ugrilainen Seura 1883-2008. [Finno-Ugric Idea and Science: The Finno-Ugric Society 1883- 
2008.] Tieteessä tapahtuu, Vol. 26, No. 8, pp. 22-26. Available at https://journal. fi/tt/article/view/780/640, last accessed on 23 January 2019.

Sjöblom, Tom 2000. Contemporary Paganism in Finland. In: Jeffrey Kaplan (ed.) Beyond the Mainstream: The Emergence of Religious Pluralism in Finland, Estonia, and Russia. Studia Historica 63. Helsinki: SKS, pp. 223-240.

Uibu, Marko 2014. Inglid ja Inglipesa internetifoorum uue vaimsuse kandjate ja legitimeerijatena. [Angels and the Spiritual Internet Forum The Nest of Angels as the Carriers and Legitimizers of the Values of the New Spirituality.] Mäetagused, Vol. 56, pp. 181-204. http://dx.doi.org/10.7592/MT2014.56.uibu.

Uibu, Marko 2016. Reemerging Religiosity: The Mainstreaming of New Spirituality in Estonia. Journal of Baltic Studies, Vol. 47, No. 2, pp. 257-274. https://doi.org/1 0.1080/01629778.2015.1113432.

Vakker, Triin 2012. Rahvusliku religiooni konstrueerimise katsed 1920.-1930. aastate Eestis: Taara usk. [Efforts to Construct National Religion in Estonia in the 1920s30s: Taara Belief.] Mäetagused, Vol. 50, pp. 175-198. http://dx.doi.org/10.7592/ MT2012.50.vakker.

Valk, Heiki 2001 [1999]. Rural Cemeteries of Southern Estonia 1225-1800 AD. CCC Papers 3. Visby: Gotland University College \& Centre for Baltic Studies / Tartu: University of Tartu, Archaeology Centre.

Valk, Heiki 2007a. Looduslikud pühapaigad kui muistised: arheoloogi vaatenurk. [Sacred Natural Places as Archaeological Objects.] In: Heiki Valk (ed.) Looduslikud pühapaigad: Väärtused ja kaitse. Õpetatud Eesti Seltsi Toimetised 36, pp. 135170. Available at https://www.maavald.ee/images/failid/hiiekogumik.pdf, last accessed on 23 January 2019.

Valk, Heiki (ed.) 2007b. Looduslikud pühapaigad: Väärtused ja kaitse. [Holy Natural Places: Values and Protection.] Õpetatud Eesti Seltsi Toimetised 36.

Valk, Heiki 2015. Pühast Võhandust, Pühalättest ja ohvrijärvest Otepää lähistel. [Sacred Waters: The River Võhandu, Spring Pühaläte and Sacrificial Lake Near Otepää.] Ajalooline Ajakiri / The Estonian Historical Journal, Vol. 1/2, pp. 3-37. https:// doi.org/10.12697/AA.2015.1-2.01.

Valk, Heiki 2018. Helme allikas: ohvrikoht tänapäeval. [Helme Spring: Sacrificial Site Today.] Tutulus: Eesti arheoloogia aastakiri, pp. 21-23.

Västrik, Ergo-Hart 2015. In Search of Genuine Religion: The Contemporary Estonian Maausulised Movement and Nationalist Discourse. In: Kathryn Rountree (ed.) Contemporary Pagan and Native Faith Movements in Europe: Colonialist and Nationalist Impulses. New York \& Oxford: Berghahn, pp. 130-153.

Virumaa 2009 = Lahemaal toimub hiite päev. [A Day of Sacred Groves in Lahemaa.] Virumaa Teataja, 19 April. Available at https://virumaateataja.postimees.ee/108483/ lahemaal-toimub-hiite-paev, last accessed on 17 January 2019.

Wallis, Robert J. 2001. Waking Ancestor Spirits: Neo-shamanic Engagements with Archaeology. In: Neil Price (ed.) The Archaeology of Shamanism. London \& New York: Routledge, pp. 213-330.

Wallis, Robert J. 2003. Shamans / Neo-Shamans: Ecstasy, Alternative Archaeologies and Contemporary Pagans. London \& New York: Routledge.

Wallis, Robert J. \& Blain, Jenny 2003. Sites, Sacredness, and Stories: Interactions of Archaeology and Contemporary Paganism. Folklore, Vol. 114, No. 3, pp. 307-321. http://dx.doi.org/10.1080/0015587032000145351. 


\title{
THE MUONG EPIC CYCLE OF 'THE BIRTH OF THE EARTH AND WATER': MAIN THEMES, MOTIFS, AND CULTURE HEROES
}

\author{
Nina Grigoreva \\ Department of Asian and African Studies \\ National Research University Higher School of Economics \\ Saint Petersburg, Russia \\ e-mail:ngrigoreva@hse.ru
}

\begin{abstract}
This article seeks to introduce into comparative folkloristics an epic tradition of the Muong, one of minority groups in northern Vietnam. More precisely, it deals with the epic cycle of 'The Birth of the Earth and Water', which represents an essential part of the Muong ritual narratives. This cycle was presumably created not later than the fifteenth century and was intended for practicing mourning rituals. Although in 2015 ritual narratives of the Muong were recognized as national intangible cultural heritage in Vietnam, the Muong epics have remained practically unknown and unexplored in Western scholarship.

The article discusses the most common epic themes, such as creation, man's origin and reproduction, acquisition of culture, and deeds and fights of the main culture heroes through a number of motifs represented in tales constituting the Muong epic cycle. Comparative analysis of these themes and motifs in global and regional perspectives reveals obvious parallels with their representations in the world folklore as well as some specific variations and local links.
\end{abstract}

Keywords: comparative analysis, culture hero, epic cycle, motif, the Muong, ritual narratives, theme, Vietnam

Research into universal archetypes and themes, classification of recurrent motifs as well as analysis of culture heroes and revealing common patterns in their representations became main defining trends within comparative folkloristics during the twentieth century. Such endeavors resulted in many seminal works which accumulate and interpret various themes and heroes, systemize and describe thousands of narrative motifs and their variants from around the world. Yet, any survey, index or directory could not be considered complete or comprehensive while accumulation of newly discovered materials from various oral traditions is ongoing ceaselessly, enriching the existing collections with formerly unknown data. 
This article seeks to involve into comparative folkloristics the new data found in oral tradition of the Muong, one of the minority groups in Vietnam. In particular, it examines some archetypal patterns in the Muong epic cycle of 'The Birth of the Earth and Water', which seems to be a piece of folk art practically unknown and unexplored outside Vietnam. The most common epic themes, such as creation, man's origin and reproduction, acquisition of culture, and hero's deeds and fights will be revealed through a number of motifs represented in tales constituting the Muong epic cycle. Through a comparative analysis of these themes and motifs in global and regional perspectives it will expose, on the one hand, obvious parallels with their representations in the world folklore and, on the other hand, some specific variations and local links. To do this, apart from using the published versions of Muong epics, I will draw on data gained through my interviews with Muong respondents about the content and pragmatics of epic texts, carried out in Vietnamese provinces of Hòa Bình and Phú Thọ, as well as in Ba Vì district of Hanoi area.

The article consists of five sections. The first one summarizes basic information on the Muong and their epics. The second one briefly reviews some conceptual issues on thematic and motific analyses in relation to the Muong epic cycle as well as provides relevant information on 'heroes studies' in folkloristics and suggests the most convenient pattern for a short discussion on the Muong culture heroes. This will be followed by three sections that look more closely into the main themes found in the epic cycle of 'The Birth of the Earth and Water' and introduce several related motifs. The fifth section also provides a preliminary analysis of the main culture heroes. The conclusion sums up the major observations made during the discussion and outlines areas for further research.

\section{THE MUONG AND MUONG EPICS}

The Muong (Muòng) are an officially recognized minority people of Vietnam ${ }^{1}$ and the closest relatives and neighbors of the Vietnamese (Kinh or Viẹt), the majority ethnic group in the country. The Muong live in settlements scattered across upland areas of several provinces of northern Vietnam - Hòa Bình, Phú Thọ, Sơn La, Thanh Hóa, as well as in Hanoi area (district of Ba Vì) and in the province of Nghệ An in the northern part of central Vietnam. According to the modern classification, the Muong and the Vietnamese together constitute the Viet-Muong sub-group of Vietic peoples and their common origin and cultural affinity is now persistently underlined in Vietnam. Vietnamese scholarly discourse claims that in ancient times ancestors of the Vietnamese and the Muong together constituted a community of the so called 'ancient Viets' (nguoòi Việt cổ). 
Yet, until the 1970s perception of the Muong and their culture had suffered from a specific attitude rooted in pre-colonial times. In the past, when the population of Vietnam did not see itself in ethnic categories, Muòng was a term that was used by Vietnamese elite in the lowlands, i.e., by Kinh people (literally 'capital inhabitants'), ${ }^{2}$ to refer to their immediate neighbors living in small villages to the west, upstream, in the hills and foothill areas. Since Viet-Muong speakers lived there intermingled with some Tai-speaking groups ${ }^{3}$, this term was historically used to designate linguistically diverse population.

Muòng is a Tai word (เมือง) meaning 'chiefdom', 'community', 'village' or 'country'. There is also a compound Muòng Mán (茫蠻) that is found in Vietnamese texts written in vernacular character script (Nôm), where Mán (蠻) appears to be the same Tai word with the same meaning but in its Han-Viet form. Initially this term was used by Chinese authors as a generic term to refer to all 'southern barbarians'. It is quite clear that the term Muòng and compound Muòng Mán were also used by the Vietnamese sinicized elite to designate 'uncivilized savages', 'mountain barbarians' without any ethnic connotation.

The emergence of the idea of 'the Muong people' as a separate ethnic group, according to Taylor, occurred in the 1920s when the term Muòng became, due to French colonial reasoning, a category to designate upland people linguistically related to the Vietnamese, or Kinh people, who were living in the lowlands (Taylor 2001). Being accepted as an official name of a minority group, the term Muòng appears to be merely an exonym since it is not used by the Muong to refer to themselves. The Muong use this term only to designate a territorial unit (a group of several settlements) or, by extension, each of the four spaces in three-level universe, according to their cosmological conception. ${ }^{4}$ Their autonym is 'Mol/Monl/Moan' (depending on the dialect), which is a Mon-Khmer ${ }^{5}$ word meaning 'people'.

Today the Muong continue to practice their traditional animist beliefs. They worship ancestral spirits, supernatural deities as well as spirits of some inanimate objects. The Muong concept of the soul, or rather numerous souls, inherent in humans and all physical beings, seems to be very sophisticated. A significant number of rituals, shamanistic by nature, are associated with this concept. Muong cosmological and religious ideas are widely represented in their ritual narratives, including tales from the epic cycle of 'The Birth of the Earth and Water'.

What is considered to be Muong epics has not attracted considerable attention in Western scholarship so far, although several tales were mentioned in descriptions of Muong funeral rites or partially retold in a few works published on the Muong and their culture (Grossin 1926; Cuisinier 1946). In Vietnam, Muong epics, as a whole cycle and a precious heritage of intangible culture, were 
discovered in the 1970s. By that time Vietnamese scholars, some of whom were ethnic Muong, had collected a significant amount of ritual narratives (Mo in Muong $)^{6}$ and had written them down in Vietnamese and also in Muong, using Vietnamese Latinized script. ${ }^{7}$ During textual analysis of collected materials scholars recognized that a certain group of tales that were recorded during mourning rituals appeared as an organic whole and looked very similar to what is commonly considered as epics. This body of tales was identified in Vietnamese as sư thi (literally, narrative verses) or truòng ca (long song), which are two terms corresponding to the European notion of epics. The opening episode (or two episodes in Thanh Hóa version) gave the title to the whole cycle - 'The Birth of the Earth and Water'. In the 1980s and 1990s Vietnamese (ĐĐĐN 1988, see Introduction by Đặng Văn Lung; Trương Sĩ Hùng 1992) and Russian (Nikulin 1985; 1996) scholars undertook the first attempts of analytical approach to Muong epics.

Tales of the epic cycle of 'The Birth of the Earth and Water' are referred to as Mo Tlêu in Muong, i.e., 'telling stories', and performed only during elaborate and lavish funerals. Unlike other Muong ritual narratives (for instance, Mo $V a i i$ 'Going back to ancestors') these tales have a certain sequence and share common heroes. They combine characteristics of both cosmological and heroic epics, narrate the origins of the world, animals and plants, the first people and their cultural practices, rulers and their deeds.

Narratives from the epic cycle are performed during nighttime, inside the Muong stilt house, with a large amount of relatives and villagers gathered around the coffin of the deceased. Recitation of epic tales is usually accompanied by a group of musicians with traditional instruments, while a Mo master could be assisted by one or two other ritual specialists. The purpose of such a performance consists in guiding the deceased's soul to the otherworld; at the same time, it is a good occasion to pass on elements of traditional culture and historical memories to younger generations. Unlike other Muong rituals, outsiders are not always welcome to attend these recitations.

Since the Muong language is unwritten, tales from the epic cycle of 'The Birth of the Earth and Water' as well as all other Muong ritual narratives have been passed down orally up to now. ${ }^{8}$ They have been transmitted mostly within families of ritual masters bố (thầy or ông) Mo who are, at the same time, professional storytellers. Tales are memorized in a certain sequence and then recited in a singing voice during lengthy funeral rites. ${ }^{9}$ The teller would, meanwhile, improvise on familiar material by drawing on a set of fixed themes, motifs, formulas, and metrical patterns, which has resulted in the appearance of a variety of epic versions spread throughout all the areas of Muong residence in northern Vietnam. To date, there are more than a dozen epic versions from 
three provinces of northern Vietnam (Hòa Bình, Thanh Hóa, Sơn La), which have been collected and published. ${ }^{10}$ The volume of poetry in these versions varies from three and a half to sixteen thousand lines, while a medium-volume version has about eight thousand lines. The collected versions slightly differ in the main characters' names, by focusing on one particular theme or another, but, generally, all of them follow a common narrative outline and share common motifs. Further in the article I will primarily draw on the earliest recorded version from the province of Hòa Bình, compiled in prose by Nguyễn Từ Chi and Nguyễn Trần Đản (ĐĐĐN 1974), referring to other versions of the epics in the case of divergences.

It remains unclear when the Muong epic cycle was created and how it evolved throughout time. The Muong authors themselves assume that the main body of epic tales could be compiled not later than the fifteenth century. According to them, this assumption is supported by genealogies of ritual masters' families, which can be traced from the end of the fifteenth century (Bùi Huy Vọng 2010: 29). Although this argument itself is not solid enough to be evidence indicating the time when the Muong epics were formed, I believe that this could well be so for two other reasons. Firstly, at the same time another part of the Viet-Muong population in the lowlands, i.e., the Kinh people, or ancestors of the modernday ethnic Vietnamese, were also creating, or at least recording, their own folk tradition. A larger part of this tradition is represented in one of the first collections of Vietnamese myths and legends entitled 'A Selection of Wondrous Tales of Linh Nam' (Lĩnh Nam chích quái liệt truyện), which demonstrates certain, though not always obvious at first glance, connections with themes and motifs found in the Moung epics. Secondly, since the Muong epic cycle, its motifs, concepts, and performing standards have much in common with Tai (or Thái as it precisely termed in Vietnam) religious and oral traditions, it might be formed in the time when the interaction between Taic and Viet-Muong people was quite intensive. As was noted by Kelley, the fifteenth century was just the time when the Lê dynasty, recently established in Vietnam (Đại Việt in that time), expanded its control into territories inhabited by Tai-speaking groups, to the west from Viet-Muong speaking areas (Kelley 2015: 182).

\section{CONCEPTUAL FRAMEWORK}

Thematic analysis is one of the useful tools for the interpretation of spoken or written narratives. In a general sense, it is applied to reveal what content a certain narrative communicates and how it is structured. Motific approach, in its turn, allows uncovering the way that the themes are represented. According to 
Daemmrich, "[t]hemes and motifs are basic components of literary works. Their arrangement, distribution, repetition, and variation form an intricate system of relationships which is an integral part of the textual structure" (Daemmrich 1985: 573). Both themes and motifs also provide a basis for identification, documentation, classification, and comparative studies of various narratives. This field of research seems to be well developed in folkloristics: in Dundes' words, "the identification of folk narratives through motif and/or tale type numbers has become an international sine qua non among bona fide folklorists" (Dundes 1997: 95).

However, there are a number of problems about thematic analysis that should be raised. Firstly, the meaning of the two terms - themes and motifs appears ambiguous in many contexts. Secondly, they are frequently, mainly in literature studies, employed interchangeably. For the sake of conceptual accuracy, it is worth to define these terms regarding the purposes of further analysis.

Themes are understood as fundamental ideas explored in a text. In folk narratives they are often universal by their nature and convey the most general ideas. Further I will discuss some of the standard epic themes, such as the creation of the universe, man's origin and reproduction, the acquisition of cultural practices, exploits of the main heroes as they are represented in the Muong epic cycle. The discussion will unfold through a number of appropriate motifs.

Motifs in narrative studies are generally defined as recurring elements with a symbolic meaning, which are used to expose and develop the major themes of the texts. According to Thompson, they are "those details out of which fullfledged narratives are composed" (Thompson 1955-1958: 10). Being memorable and easily repeatable patterns, motifs through repetition can vary and produce other themes or narratives as well as be reproduced in other forms of folk culture (song lore, imitative arts, etc.). Although the understanding of the term 'motif' differs from one scholar to another, ${ }^{11}$ the motific approach remains one of the main methods in the field of folk narratives documentation and comparative folkloristics. It is also widely used for introducing new texts.

In the Muong epic cycle motifs are easily identifiable since the cycle represents a sequence of clearly delineated and untitled tales, every one of which is marked by a new rằng, i.e. 'saying that'. The number and sequence of tales vary from one version of the epic cycle to another but, as a rule, a certain set of tales is included in all versions of the cycle: the birth of the Earth and Water, the birth of months and days, the birth of the sacred egg, asking for the fire, planting mulberry trees and breeding silkworms, building a house, matchmaking, the birth of the buffalo, the birth of the hen, water rising and drying up, the birth of rice, the birth of 'tube wine' (ruoou cần $)^{12}$, the birth of the 
bronze drum, the birth of the bowl, fighting an enemy, cutting the tree of Chu, burning the ruler's palace, hunting the monster. ${ }^{13}$ As can be seen, the larger part of the listed titles correlates with the motifs which are mentioned in section A of Thompson's Motif-Index and called 'Mythological motifs' (Thompson 1955-1958). Such an abundance of mythological motifs in the Muong epic cycle has given grounds for some scholars to consider the cycle as a variety of epic mythology. Thus, Nikulin identifies Muong epic tales as a 'mytho-epic cycle' (Nikulin 1985, 1996) while Trương Sĩ Hùng calls them 'mythic epics' (sủ thi thần thoại, Trương Sĩ Hùng 1992).

Thompson defines mythological motifs as those "having to do with creation and with the nature of the world: creators, gods, and demigods; the creation and nature of the universe, and especially of the earth; the beginnings of life; the creation and establishment of the animal and vegetable world" (Thompson 1955-1958: 20). In short, mythological motifs are the ones with 'explanatory' or 'etiological' quality, and motifs of the Muong epic cycle certainly match this category. At the same time, the peculiarity of Muong mythological motifs consists in the fact that they do not narrate stories about gods or supernatural creators since the process of creation and acquisition of culture occurs, according to Muong epics, due to the very nature or with participation of the first people and culture heroes, all of whom appear to be fairly earthly beings. Such a situation is typical of oral tradition of many peoples in Southeast Asia, whose worldview is widely influenced by animistic beliefs. Whereas there is no any specialized motif-index of Southeast Asian folklore, in further discussion I will refer to Thompson's classification despite the fact that not all motifs of Muong epics are represented there.

Whereas the Muong epic cycle seems to be more mythological (etiological by nature) rather than heroic, the analysis of its main culture heroes might provide a better understanding of this valuable piece of folk culture in its whole context. A typical culture hero, as this category is understood in folkloristics, might be represented as a creator-demiurge, redeemer and benefactor, as well as a discoverer of cultural practices, traditions or religion. He (or she, hardly ever) achieves great deeds on behalf of his people, tribe or civilization, and very often turns out to be the founder of the first ruling dynasty. Two characters depicted in Muong epic tales, namely, the ruler Tá Cần and especially King Dit Dàng, clearly meet the cited criteria. Yet, a notable feature of these personages is that they do not participate in the creation process as they appear on the stage when the universe and main natural phenomena have already been formed. Their main function is solely focused on the acquisition of cultural practices and establishing of social order. In this way, they act as creators of the real world adapted for human life. 
The so-called 'hero studies' were actively developing during the twentieth century and resulted in a number of seminal works among which the following are worth mentioning: 'Myth of the Birth of the Hero' by Otto Rank (Rank 1990 [1909]), 'The Hero: A Study in Tradition, Myth and Dreams' by Lord Raglan (Raglan 1990 [1936]) as well as Joseph Campbell's 'The Hero with a Thousand Faces' (Campbell 2004 [1949]). While the 'hero's journey' archetype outlined by Campbell (departure - initiation - return) is not well represented in Muong epics, the applying of the so-called 'hero pattern' initially elaborated by Rank and then developed by Raglan appears to be more appropriate for a short discussion on main culture heroes found in the Muong epic cycle.

\section{CREATION OF THE UNIVERSE: MOTIF OF GREAT DELUGE. MOTIF OF TREE OF LIFE}

In the opening part of the Muong epic cycle there is a 'rằng', i.e. a tale, or two 'rằng', depending on the version, talking about the origins of the Earth and the Water 'in the times when there is not yet the Earth down on the earth and there is not yet the Sky up in the sky':

That was a long time ago ... So long ago that it is impossible now to count years or months. There were neither years nor months then. Years and months had not existed yet... There were no seasons. There were neither days nor nights. There was no sun, nor moon, there were no stars. The sky and the earth were merged into a single mass then. (ĐĐĐN 1974: 5)

As in many other Muong stories, here one can find a mention of a drought that precedes the big rain:

...That was a time of terrible drought. The drought lasted very long. The sky and the earth were thrown into turmoil. (ĐĐĐN 1974: 6)

...Suddenly, heavy black clouds rolled out from nowhere. Impenetrable. Scary. Thunder rumbled loudly and wind roared all around. Lightning struck down and split the sky out of the earth. It was pouring with rain. Endlessly, without stopping. Small drops of the rain were as fruits of a ficus and large drops were as fruits of a giant fig. Wind was mixed with rain, rain filled the wind, the wind and rain were swirled in a terrible vortex.

Wind gusts filled the sky with air and raised it up. Rainwater softened the ground, but kept flowing with unusual force, turning into streams and flooding all around. The water had risen and stayed, separating the 
sky from the earth. Thus, the sky, the earth, and the water had appeared. (ĐĐĐN 1974: 7)

The motif of the great deluge or the flood myth is a very common pattern in worldwide folklore (Motif A1010 'Deluge. Inundation of whole world or section' in Thompson's Motif-Index). Its common meaning is to mark a new beginning after a great catastrophe, usually sent by deities. It is often an act of divine retribution that destroys the previous order. However, in Muong epics one can find a slightly different situation: the flood does not seem to be a kind of punishment or retribution. It is just the beginning of time since before the flood there was nothing in the world. In addition, it is worth mentioning that droughts alternating with rains can be attributed to specific features of Southeast Asian climate which is strongly influenced by monsoons. According to the Muong lunar calendar, the New Year, which is associated with spring and the beginning of a new life, also always falls on the end of the dry season turning into the season of big rains. On the whole, the motif of the great flood, which precedes the formation of the Universe and origin of mankind, is a very typical pattern in the Southeast Asian folklore (see Oppenheimer 1998; Stratanovich 1977).

A big rain after a terrible drought and a flood caused by it created the Universe. However, the earth was still uninhabited. In Muong epics the origin of mankind is connected with two other widespread motifs: the motif of tree of life and the motif of origin from eggs. Let us focus first on the motif of tree of life as it is represented in the Muong epic cycle and rituals.

Benjamin ficus tree, Cây Si in Muong, is considered to be a symbol of human life in Muong spiritual tradition. The Muong believe that everyone's soul is connected with a symbolic $S i$ tree planted in the sky. When trees of $S i$ are lush and green, the people who are connected with them are strong and healthy, but when the trees lose their leaves and dry, people become ill and die (cf. E760 'Object or animal has mystic connection with person. Changes in one correspond to changes in the other' in Thompson's Motif-Index). There is a special ritual termed 'pulling the $S i$ ' (Lế kéo $S i$ ) which appears to be similar to 'soul pulling' or 'soul retrieval' rituals in shamanistic traditions of other peoples in the world, and the purpose of which is to strengthen forces of the elderly, ill or weak people. ${ }^{14}$

The motif of tree of $\mathrm{Si}$, as it is depicted in Muong epics, also correlates with Thompson's E761.3.4. 'Life token: trees prostrate themselves', since miraculous emergence, unusual growth, and subsequent prostration of the tree had caused many transformations in the world. Thus, its big and small branches had transformed into Muong villages and settlements; when the tree toppled down, its fallen leaves became birds (symbol of the upper world in Muong culture) while its roots, drowned in the water, turned into fishes (symbol of the 
lower world and water realm); the stump of the tree ${ }^{15}$ gave birth to a pair of birds-progenitors. ${ }^{16}$

\section{MAN'S ORIGIN AND REPRODUCTION: MOTIF OF ORIGIN FROM EGGS. MOTIF OF INCEST}

The Muong story of descent links the origin of the first people (of the Muong as well as of some other neighboring peoples, such as the Kinh, i.e., ethnic Vietnamese, the Lao, the Thai, the Man, and the Meo) with eggs laid by a pair of birds Chim Ây and Cái Ú' $a^{17}$, which flew out of the ruined tree of Si. While all of a thousand (or sometimes ten thousand) first cracked eggs gave birth to various animals and other peoples, the last egg (or sometimes three last eggs) contained two brothers and a sister who became ancestors of the Muong. In Hòa Bình versions of the epic cycle the last egg is often named Điếng (ĐĐĐN 1976; Mo Mường Hòa Bình 2011) and it usually possesses certain distinctive features, to the point that it can even take the form of a square ( ĐĐÐN 1974).

The motif of origin from egg/eggs (A1222 'Mankind originates from eggs', according to Thompson's Motif-Index classification) is not only specific to the Muong epics but also represented in oral tradition of some other peoples in Asian and Pacific region (Stratanovich 1977: 62-73). Likewise, this motif seems to be echoed in the Vietnamese story of descent which narrates how the first Vietnamese appeared from one hundred eggs found in a sack born from the Father-Dragon and Mother-Fairy. ${ }^{18}$

In archaic mythology the first emerged heroes, either gods or mortals, are frequently depicted at once as brother and sister as well as husband and wife (cf. Zeus and Hera in Greek mythology, Chinese Fu Xi and $\mathrm{Nu} \mathrm{Wa,} \mathrm{and} \mathrm{so} \mathrm{on).}$ As they are the only two human beings in the world or very few within a newly emerged community, they marry among themselves to continue their race. Incest between gods or demigods is classified under section A 'Mythological Motifs' (A1273.1. 'Incestuous first parents') in the Thompson's Motif-Index, while incest between mortals occurs in section T 'Sex', within subsection T400 'Illicit Sexual Relations'. As the Muong progenitors are not considered to be gods or deities, I believe that the motif T415 'Brother-sister incest' seems to be more appropriate for analyzing Muong epics.

The motif of sibling incest along with the motif of the great deluge is a very specific pattern in Southeast Asian creation myths (Stratanovich 1977). It has two main versions: 1) brother and sister are the sole survivors of a flood; 2) two brothers and a sister appear in some miraculous way after a flood; the elder brother in the course of a certain testing turns to be unable to govern and/or 
to continue the human race; then the younger brother becomes the ruler and marries the sister to give birth to their offspring.

In Muong epics this motif is linked with the motif of the great deluge through origin from eggs: the first Muong people that hatched from the last/squared egg (or from three last eggs) are two brothers and a sister - Tá Cần, Tá Kài and cô nàng Kịt. The younger brother then becomes the first Muong ruler, Lang Tá Cần. After a twice-failed attempt of marriage (with the daughter of the king of the sky and with the daughter of the king of the underwater realm) the ruler Tá Cần marries his sister (nàng Kịt):

...that was a time when no one knew the Law of the Heaven. But as they had violated the Heaven's Law therefore the Heaven must punish them. (ĐĐĐN 1974: 36)

As a result of the Heaven's wrath, all the children born from this family pair are physically disabled - without arms, without legs, dumb, or deaf. Then one wise old man teaches the parents how to remedy the situation:

The Law of the Heaven does not allow brothers and sisters to marry among themselves. Only chickens and pigs can have such promiscuous relations. Both of you are the first people who were born from the squared egg, you are a brother and a sister, you should not be a husband and a wife. But, well, it has already happened; I have to find the way to correct it somehow. Now you have to leave each other. Let the man go to the east, and the woman go to the west. When you come back and meet each other, you have to pretend that you are not intimate, that you have never known each other. When you will be eating, the woman should eat in a shelter for chickens and the man in a pen for pigs, as if you are no different from animals. Then you have to have the wedding ceremony, with matchmaking rituals, according to the rules ... Maybe then you will be able to avoid the punishment of the Heaven. (ibid.)

Obviously, the motif of incest between the first parents is used in the context of Muong epics not only to narrate the way of ancestors' multiplying but also to taboo incestuous marriage and introduce norms of marital relations. The sibling incest committed by progenitors seems to be punished for but not strictly condemned. Such a representation supports the assumption made by Meletinskii concerning the ambivalence of the motif of incest in folklore: being aimed to eliminate incestuous relationship incest, per se, does not appear to be reproved since it is attributed to creation and considered to be inevitable (Meletinskii 1984). 
The motif of incest is not implicitly represented in the Vietnamese origin myth which was to a great extent rooted in Chinese written sources (Kelley 2012) and strongly influenced by Confucian ethics. However, some traces of the common Viet-Muong oral tradition are found in the Vietnamese story of descent as well: the Father-Dragon and Mother-Fairy also have to separate and go to opposite directions for some ambiguous reasons. In the Vietnamese story the spouses' separation is explained by the opposition of yin (âm) and yang (duong) which, on the one hand, is needed for producing offspring but, on the other hand, hinders a long cohabitation (Lĩnh Nam Chích Quái 2001: 31-32). As appealing to the Daoist categories of yin and yang sounds so vague and unconvincing in such a context, I believe that this association could be used in the Vietnamese story of descent to veil the previous connection with the motif of incest between progenitors, which was specific to the common Viet-Muong tradition.

\section{ACQUISITION OF CULTURE. THE MAIN CULTURE HEROES}

Motifs narrating the acquisition of culture constitute a significant part of Muong epics. They comprise some widespread motifs such as asking for fire (A1414 'Origin of fire'), acquisition of a house (variant of the A1402 'The gods build houses...'), livestock (buffalo, hen, pig - A1422 'Assignment of edible animals'), rice (A1423.2 'Acquisition of rice'), fermented rice wine (ruọu cần; A1427 'Acquisition of spirituous liquors'), metals (A1432 'Acquisition of metals') and ornaments (A1465.3 'Origin of ornaments'). In addition to that, the Muong epic cycle also contains several motifs that are not found in the existent motif-indexes. Such motifs, specific to the cultural area of Southeast Asia and Southern China, include motifs of the acquisition of sericulture, origin of the bronze drum (a ritual instrument used during funerals and a symbol of the ruler's authority), and the origin of the bowl.

Since there are no gods in the world of Muong epics, the acquisition of culture is performed by the first rulers - Tá Cần or his son, King Dịt Dàng, ${ }^{19}$ who appear to be two culture heroes. In the process of acquiring the elements of culture, they are assisted by numerous helpers or mentors, represented by a variety of living creatures or objects of nature. Thus, to obtain fire, the ruler Tá Cần first asks 'uncle Bat' (bác Gioi) ${ }^{20}$ to bring fire from the sky down to the earth (literally, 'from the realm of the sky down to the realm of people'). When Bat fails to bring fire to people (because an evil spirit has spilled water on the burning coals to extinguish the fire), the ruler asks 'uncle Horse-fly' (bác Ruồi trâu, literally 'Buffalo-fly') to do this. Although coals obtained in the sky the second time have again been sprinkled with water, the horse-fly has managed 
to deceive the master of fire, snoop on the way of making fire in the sky and convey it to people: to have fire, one needs to rub two bamboo sticks against each other near dry tinder made of split bamboo. Thereby, people have acquired fire to prepare their food while the horse-fly has merited the right to bite buffaloes and bulls in their back, bite people carrying yokes on their shoulders, and also bite beautiful young girls in different parts of their gentle body (ĐĐĐN 1974: 20-23).

Thus, like in many other world mythologies, in the Muong epic tales fire is obtained in a dishonest way (cf. the myth of Prometheus or some myths of Native Americans and peoples of the Amazon River basin). Characteristically, in Muong epics the theft of fire is also, as incest, not punished; on the contrary, the horse-fly who stole the fire and transmitted it to humans, gets rewarded even though such a reward seems to be merely an excuse for unpleasant actions produced by this animal creature. I believe that such interpretation is used by animism believers to emphasize nature's harmony and interrelationship between humans and the entire natural world.

To acquire every element of culture, the hero normally has to make two or three attempts. According to Muong epics, nothing is given to people on the first try. An example of this would be the motif narrating the acquisition of a house. It tells that the tortoise that was caught and then released by the ruler Tá Cần taught people a way of building houses: a house has to be similar to the tortoise's body - four main pillars are the tortoise's four paws; the ridge beam is its spine; lathing is its ribs; the front door is the tortoise's mouth, while the back door is its anus; trunks of wild sugarcane should be used to make minor pillars and bast of rattan stems to bind them together. The ruler Tá Cần and his people did exactly what the tortoise said but the first built house collapsed. Then the ruler Tá Cần caught the tortoise again and asked for explanations. The tortoise specified some details: the main pillars have to be made of ironwood and beams of wood of melia or dracontomelon. ${ }^{21}$ Bast for binding has to be made from aganonerion ${ }^{22}$, while the roof should be covered with straw (ĐĐĐN 1974: 23-26).

The acquisition of sericulture and silk weaving (in those epic variants where this motif is found ${ }^{23}$ ) is associated with women. In the Hòa Bình version of the epic cycle it is nàng Kịt, the ruler Tá Cần's sister and wife, who is involved in the process of acquiring silk. She had already learned to cultivate mulberry trees (it had been found out that trees should be planted in the fifth lunar month), but she had no silkworms yet. Nàng Kịt had to go very far across high mountains and deep rivers to meet $B a ̀$ Dit Bà Măm, a lonely old woman who was living in a dense forest (it is unclear whether this woman was a human or a spirit) and ask for silkworms. After that, Muong girls and women learned to breed 
silkworms, make silk thread, and produce cloth to sew clothes. Since then the Muong people had no need to wear loincloths made of liana and cover themselves with blankets made of tree bark (ĐĐĐN 1974: 26-28). In the variant of the epic cycle recorded in Son La province, the acquisition of silk is associated with Bì Dịt Dàng, wife of the king $D i ̣ t$ dàng, whereas narrating of the tale follows nearly the same template as in Hòa Bình variant of the epic (ĐĐĐN 2005: 291-298).

The motifs of acquisition of metals and ornaments, as they are represented in the Hòa Bình and Sơn La versions of the epic cycle, are connected with the king Dịt Dàng and his deeds. The king Dịt Dàng, the youngest of the children born from the first Muong parents (the ruler Tá Cần and nàng Kitt, his sister and wife), appears to be the main culture hero. It is remarkable that some Vietnamese scholars believe that the name Dit Dang (sometimes Yịt Yàng) is a Muong pronunciation of the term Việt Vuong, meaning 'the king of the Viet' (Nguyễn Từ Chi 1997: 131). This assumption is supported by available details of the king's life story: unlike his brothers and sisters who scattered all over the uplands to manage the settlements, Dịt Dàng went down to the plains and became the king in the area of Kinh Ky Ké Cho , i.e. in the capital city with a market place, that is to say, in the area of the Kinh (or Viet) people in modern categories.

Characteristically, in the version of epics from Thanh Hóa, which is a province more remote from the capital city, modern Hanoi, the king Dịt Dàng receives far less attention as compared to the Hòa Bình and Sơn La variants of the epic cycle. Another interesting point is that some specific episodes narrating the Dit Dàng reign have obvious associations with the deeds committed by the Vietnamese culture hero - the Father-Dragon Lac Long Quân - as they are depicted in a fifteenth-century collection, 'A Selection of Wondrous Tales of Linh Nam' (Lĩnh Nam Chích Quái 2001). The revealed parallels will be discussed in more detail below. At the same time, some other very typical episodes have absolutely no association in Vietnamese tradition: Dịt Dàng's 'treachery', or rather ingratitude towards people from the uplands, the subsequent burning of his palace, and a military campaign of the uplanders against the king.

In the Hòa Bình and Son La variants of the epics, the deeds committed by the king $D i t$ Dàng include victorious battles, cutting down the tree of Chu with its 'bronze trunk, iron branches, brass flowers and tin fruits', building a palace and defeating an animal monster Tìn Vin Tuong Vuọng. Two of his deeds - defeating the monster and cutting down the tree - are reminiscent of the deeds of the Vietnamese culture hero, the Father-Dragon Lac Long Quân, as they are depicted in two stories from 'A Selection of Wondrous Tales of Linh Nam' - 'The story of the Fox essence' (Truyện Hò tinh) and 'The story of the Tree spirit' (Truyện Mộc tinh) (Lĩnh Nam Chích Quái 2001: 42-44, 57-60). While 
in Vietnamese stories the Father-Dragon merely saves people from malicious creatures and his deeds remain engraved in certain geographic sites around today's Hanoi, in Muong epic tales one would discover an explicit etiological context. Thus, the king Dịt Dàng not only defeated the monster Tìn Vìn Tuọng Vuọng and saved his people from trouble but also divided the monster's body into many parts. The Muong from different settlements as well as some neighboring peoples took different parts of the monster's body and carried them far away to their places of living to imitate drawings on the monster's skin. In such a way young girls and women have learned to weave and embroider different ornaments on the textiles they make (ĐĐĐN 1974: 94-100).

A victory over the animal monster is attributed mostly to the main culture hero only in the Hòa Bình and Sorn La versions of the epic cycle. According to Thanh Hóa variant of the Muong epics, this terrible beast was defeated collectively by people from different settlements led by their first rulers. ${ }^{24}$ Characteristically, the tale narrating the way of defeating the monster here is followed by another tale which tells about the extermination of two other malicious creatures - crazy fish (cá điên) and crazy crow (quạ điên) (ĐĐĐN 1975: 234244). Victories over all the three mentioned creatures - animal-monster, fish, and crow (bird) - once again appeal to the Muong conception of a three-level universe and its symbols. Extermination of the harmful creations of the upper world, earthly world, and lower world symbolizes control gained over the whole universe where, according to animistic beliefs, the seen world is interrelated to the unseen one. In the Vietnamese collection titled 'A Selection of Wondrous Tales of Linh Nam', in addition to the above-mentioned stories of Fox essence and Tree spirit, one can also find a tale depicting the victory gained by the Father-Dragon Lac Long Quân over the Fish essence (Ngu tinh) (Lĩnh Nam Chích Quái 2001: 39-41). In this way, in Vietnamese tradition the idea of three great deeds committed by progenitor(s), which is found in the Thanh Hóa variant of the epic cycle, is also represented; however, the emblematic association with the three-level structure of the universe seems to be lost.

Although the first king Dịt Dàng is depicted as a leader, civilizer, and savior of his people, even in the Hòa Bình and Sơn La variants of the Muong epics the 'hero cycle' does not appear to be well-developed. From twenty-two points outlined by Raglan for the typical 'hero pattern' (Raglan 1990 [1936]: 89-165) only eleven would hypothetically fit in the king Dịt Dàng life story (see Appendix 1). We are completely unaware of the king's children and continuation of the dynasty, his death, and posthumous veneration. Nearly nothing is said about the king's wife. Such a 'shortage' of the heroic content in Muong epics might be explained by the lack of political ambitions among the creators of the epics. Actually, we should keep in mind that ancestors of those people who 
are now referred to as the Muong have never had their own statehood in the uplands whilst political power has been always located in the lowlands (in the area of the capital city and the market place - Kinh Ky Kẻ Cho'), i.e. beyond their habitual landscapes, both natural and cultural.

\section{CONCLUDING REMARKS}

A brief overview of the Muong epic cycle of 'The Birth of the Earth and Water' clearly demonstrates that this epitome of oral creativity, practically unknown and unexplored in Western scholarship, represents a full-fledged product of the epic genre and appears to be well-deserved to take its place among the world's greatest epics. The tales constituting the cycle, their themes and motifs are deeply interrelated with animistic beliefs and cosmological ideas of the Muong people. As the Muong say themselves, Mo Tlêu, i.e. narratives of the epic cycle of 'The Birth of the Earth and Water', is a kind of unwritten encyclopedia of their life.

The tales of the cycle are compiled in the oral-formulaic tradition and intended for practicing long drawn-out mourning rituals. The time of creating of the epic cycle remains unclear but a number of indirect evidences allow assuming that it was developed no later than the fifteenth century.

As was shown, Muong epics narrate canonical epic themes, such as the creation of the universe, origin of mankind, acquisition of culture, mostly through a number of globally occurring motifs which are represented in Thompson's Motif-Index of Folk Literature (Thompson 1955-1958). They include the motif of the great deluge, motifs of the tree of life, origin from eggs, incest, acquiring of fire, rice, metals, building a house, and so on. Characteristically, none of these motifs in the Muong tales are associated with gods or deities as it occurs in most other epics or epic mythologies, but with various facets of local nature. Thus, according to Muong epics, the beginning of life is connected with heavy rain after severe drought and the huge ficus tree (the tree of $S i$ ) which embodies the idea of the tree of life in the Muong beliefs; fire is obtained in the sky by the horse-fly; the way of building a house is taught to people by the tortoise, and so forth. Obviously, this peculiarity of Muong epics is caused by an animistic worldview, assuming that humans are a part of the omnipotent nature and could be influenced by spirits of visible and invisible realms.

Along with worldly widespread motifs, Muong epic tales also comprise a number of motifs which are not found in Thompson's Motif-Index or in other motif inventories, and appear to be specific for the Southeast Asian culture area. They 
include motifs of acquiring the bronze drum, the bowl, acquiring sericulture and silk weaving.

Regarding the heroes represented in Muong epic tales, one should acknowledge that, unlike many other epics in the world, the cycle of 'The Birth of the Earth and Water' seems to be more mythological than heroic since it primarily focuses on giving accounts of the origins of various natural phenomena and core cultural practices rather than on depicting culture heroes, gods or the first rulers and their deeds. Actually, it appears to be more appropriate to consider this cycle as a variety of epic mythology rather than mere epics in the conventional sense of the term.

Although the tales constituting the Muong epic cycle and Vietnamese core myths and legends, as they are represented in the fifteenth-century 'Selection of Wondrous Tales of Linh Nam', were recorded five centuries apart and, at a glance, do not distinctively share common themes or heroes, an in-depth motific analysis reveals obvious parallels and interpretable divergences so that medieval Vietnamese mythology clearly appears as a more sinicized version of the Muong (or, evidently, formerly common Viet-Muong) narrative traditions. Thus, Vietnamese medieval myths and legends, explicitly or implicitly, echo a number of common Viet-Muong motifs, also found in the Muong epic cycle, such as origin from eggs, separation of progenitors as a punishment for the committed incest, overgrowth and subsequent destruction of the tree of life, defeating harmful creatures, such as an animal-monster (Fox essence in the Vietnamese case) or malicious fish. Characteristically, while all the motifs in Muong tales have evident etiological context and embody certain religious ideas, such as the conception of a three-level structure of the universe, for instance, in Vietnamese myths and legends the initial conceptual or etiological context seems to be blurred or reinterpreted.

Numerous parallels between the Muong and Tai (Thái) cultural practices, religious concepts, and narrative traditions revealed during the analysis might become a subject for further research.

In June 2015, ritual narratives of the Muong from the province of Hòa Bình, including tales from the epic cycle of 'The Birth of the Earth and Water', were awarded a certificate of special safeguarding by the Viet Nam National Commission for UNESCO. Obviously, in the coming years Vietnamese authorities will make all necessary efforts to have these narratives, together with traditions of their oral transmission and performance, recognized by UNESCO as world heritage. I believe that, compared to some other nominated culture objects and sites in Vietnam, Muong ritual narratives undeniably deserve this honor as they represent real oral heritage that brings to modern society cultural values and historical memories of previous generations. If this happens, the Muong 
epic cycle will become a part of the Intangible Cultural Heritage of Humanity along with some other Asian epics, such as Kyrgyz Manas, Yakut Olonkho, and Hudhud chants of the Ifugao people. Heritagization of the ritual narratives of the Muong people, including the cycle of 'The Birth of the Earth and Water' as their most essential component, will certainly contribute to further more detailed research into this cultural phenomenon and invaluable part of folk art. Hopefully, it will not seriously threaten the narratives as well as practices of their performance owing to standardization, decontextualization, and commercialization, which often accompany the process of heritagization.

\section{APPENDIX 1.}

\section{King Dịt Dàng as a culture hero}

(according to the Hòa Bình and Sơn La variants of the epic cycle)

\begin{tabular}{|c|c|c|c|}
\hline & $\begin{array}{l}\text { Twenty two points of the 'hero } \\
\text { pattern' according to Raglan }{ }^{25}\end{array}$ & Yes/No & Comments \\
\hline 1. & His mother is a royal virgin & $+(?)$ & $\begin{array}{l}\text { Nàng Kit, sister and wife } \\
\text { of the ruler Tá } C \text { ân; one of } \\
\text { the first people who were } \\
\text { born from eggs laid by } \\
\text { birds-progenitors }\end{array}$ \\
\hline 2. & His father is a king, and & + & $\begin{array}{l}\text { Ruler Tá Cần, one of the } \\
\text { first people who were born } \\
\text { from eggs laid by birds- } \\
\text { progenitors }\end{array}$ \\
\hline 3. & $\begin{array}{l}\text { often a near relative of his } \\
\text { mother, but }\end{array}$ & + & $\begin{array}{l}\text { His father and mother are } \\
\text { brother and sister }\end{array}$ \\
\hline 4. & $\begin{array}{l}\text { the circumstances of his } \\
\text { conception are unusual, and }\end{array}$ & + & $\begin{array}{l}\text { He was born from } \\
\text { incestuous marriage }\end{array}$ \\
\hline 5. & $\begin{array}{l}\text { he is also reputed to be the son of } \\
\text { a god. }\end{array}$ & - & $\begin{array}{l}\text { There are no gods in } \\
\text { Muong epics }\end{array}$ \\
\hline 6. & $\begin{array}{l}\text { At birth an attempt is made, often } \\
\text { by his father, to kill him, but }\end{array}$ & - & \\
\hline 7. & he is spirited away, and & - & \\
\hline 8. & $\begin{array}{l}\text { reared by foster parents in a } \\
\text { faraway country. }\end{array}$ & - & \\
\hline 9. & $\begin{array}{l}\text { We are told nothing of his } \\
\text { childhood, but }\end{array}$ & + & \\
\hline
\end{tabular}




\begin{tabular}{|c|c|c|c|}
\hline 10. & $\begin{array}{l}\text { when reaching manhood, he } \\
\text { returns or goes to his future } \\
\text { kingdom. }\end{array}$ & + & $\begin{array}{l}\text { He went down to the } \\
\text { plains and became king } \\
\text { in the area of Kinh } K \dot{y} K e \\
C h o, \text { i.e., in the capital } \\
\text { city with a market place }\end{array}$ \\
\hline 11. & $\begin{array}{l}\text { After a victory over the king and/ } \\
\text { or a giant, dragon, or wild beast, }\end{array}$ & + & $\begin{array}{l}\text { He defeated the monster } \\
\text { Tin Vin Tuong Vuong }\end{array}$ \\
\hline 12. & $\begin{array}{l}\text { he marries a princess, often the } \\
\text { daughter of his predecessor, and }\end{array}$ & - & $\begin{array}{l}\text { No data on his wife. } \\
\text { The only information } \\
\text { is, according to Son La } \\
\text { variant of the epic cycle, } \\
\text { that she contributed to the } \\
\text { acquisition of sericulture }\end{array}$ \\
\hline 13. & becomes king. & + & \\
\hline 14. & $\begin{array}{l}\text { For some time he reigns } \\
\text { uneventfully, and }\end{array}$ & + & \\
\hline 15. & prescribes laws, but & + & \\
\hline 16. & $\begin{array}{l}\text { later he loses favor with the gods } \\
\text { and/or his subjects, and }\end{array}$ & + & $\begin{array}{l}\text { His palace in the plains } \\
\text { was burnt by people from } \\
\text { the uplands }\end{array}$ \\
\hline 17. & $\begin{array}{l}\text { is dethroned and driven out of the } \\
\text { city. }\end{array}$ & - & \\
\hline 18. & $\begin{array}{l}\text { He meets with a mysterious } \\
\text { death, }\end{array}$ & - & $\begin{array}{l}\text { No information on his } \\
\text { death }\end{array}$ \\
\hline 19. & often at the top of a hill. & - & \\
\hline 20. & $\begin{array}{l}\text { His children, if any, do not } \\
\text { succeed him. }\end{array}$ & - & $\begin{array}{l}\text { No information on his } \\
\text { children }\end{array}$ \\
\hline 21. & $\begin{array}{l}\text { His body is not buried, but } \\
\text { nevertheless }\end{array}$ & - & \\
\hline \multirow[t]{2}{*}{22.} & $\begin{array}{l}\text { he has one or more holy } \\
\text { sepulchers. }\end{array}$ & - & \\
\hline & Total score & 11 & \\
\hline
\end{tabular}

\section{ACKNOWLEDGEMENTS}

This research was supported by the Russian Foundation for Humanities, project № 16-24-09001. 


\section{NOTES}

1 According to the 2009 Census, the Muong population in Vietnam amounted to about 1.3 million people (Census 2010: 134).

${ }^{2}$ Kinh is a Chinese borrowing, meaning 'capital city' or, by extension, 'capital inhabitants' (Chinese Jīng, 京).

3 Hereinafter the term 'Tai' is used as a general term to refer to the speakers of any Tai language in the Tai-Kadai (or Cra-Dai) language family. Actually, Vietnamese scholars make a distinction between 'Tày' (Central Tai) and 'Thái' (Southwestern Tai) languages and peoples. As today the Muong mostly live side by side with those Taispeakers who are named Thái, according to Vietnamese classification, I will sometimes employ this specific term to refer to this group.

4 According to Muong cosmological conception, the universe is composed of three worlds disposed along a vertical axis - the upper world (tloi), the flat world on the earth (pua bằng) and the underworld (pua tịn). While the upper world corresponds to the muong of the sky (muòng tloi or muòng kloì) and the flat world corresponds to the muong of people (muòng mol), the underworld is divided into two different muongs - the muong of spirits (muòng $\mathrm{ma}$ ) and the muong of the king of underwater (muòng púa khú). For more on this, see Nguyễn Từ Chi 1997.

5 Vietnamese and Muong languages constitute the Viet-Muong subgroup of the Vietic languages within the Mon-Khmer branch of the Austro-Asiatic language family.

6 Mo is a Tai word meaning ritual narratives, ritual recitations, and ritual specialists in Muong.

7 The so-called Muong language consists of a number of closely related dialects, all of which officially remain unwritten. Although the official implementation of a standardized writing system for the Muong language seems to be problematic because of significant language variations, practically all types of Muong texts can be recorded

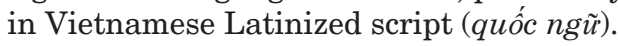

8 There is a story explaining why the Muong do not write down their tales but have to memorize them: Once the Muong were bringing characters back to their home but when they crossed a stream they put characters into the mouth and inadvertently swallowed them. Since then, when the Muong need to tell stories, they have to get scripts off from their entrails (ĐĐĐN 1988: 9). The last expression 'to get scripts off from their entrails' is associated with the starting moment of recitation when the ritual master is 'trying his voice' by producing sounds similar to a kind of throat singing.

A similar story is typical for some other peoples of northern Vietnam, which have no script for their languages.

9 To prevent a dead body from rotting and preserve it for lengthy funeral ceremonies (up to eighteen days in the past), the Muong would use some local herbs (information gained during fieldwork in 2015).

${ }^{10}$ For a survey of the published versions of Muong epics see Mo Mường Hòa Bình 2011, pp. 14-17. 
${ }^{11}$ Highlights of the motif in literature relevant for the current research include BenAmos 1980, 1995; Dundes 1962, 1997; Nekliudov 2004; Veselovskii 1989 [1940].

12 'Tube wine' (ruơu cần) is a fermented alcoholic beverage (up to 25\% alcohol) prepared of cooked glutinous rice. This beverage is consumed, often collectively, through long, thin cane tubes that are put into a jar.

${ }^{13}$ The cited list of tales is specific to the Hòa Bình version of Muong epics (ĐĐĐN 1976, for instance). In the Thanh Hóa variant, there are twenty-eight tales, some of which are titled a little bit differently: 'delineating years and months', 'looking for a pig, looking for a hen’, and so on (ĐĐĐN 1975).

${ }^{14}$ For more on this among the Muong see Bùi Huy Vọng 2015: 72-83; Đặng Văn Tu 1988; Phùng 2015.

${ }^{15}$ Nikulin has suggested that the famous Dong Son bronze drums, numerously found in northern Vietnam, could represent a symbolic stump of the Muong tree of life (Nikulin 1995, 1996). I do not find this convincing as I have never observed any associations of the tree of $S i$ with the bronze drum - neither in Muong rituals nor in oral tradition.

${ }^{16}$ Nikulin mentions that the scene of cutting the tree of $S i$ is found in the epic cycle 'The Birth of the Boundless' (Äm Êt Luông) of the Thái people in northern Vietnam (Nikulin 1996: 129-130). Unfortunately, so far I have had no possibility to compare the perception of the tree of $S i$ among the Thái and the Muong.

${ }^{17}$ In the Thanh Hóa variant of epics the birds are named Tùng (male) and Tót (female) trống chim Tùng, mái chim Tót (ĐĐĐN 1975).

${ }^{18}$ An appealing interpretation of the motif of origin from eggs was suggested by the Russian scholar Stratanovich. Analyzing two main patterns of descent typical of the oral tradition in Southeast Asia (descent from egg/eggs or descent from gourd), Stratanovich suggested that the motif of origin from eggs might be an evidence of a 'second birth'. That is to say, according to Stratanovich, the pattern of descent from eggs, unlike the origin from gourd, could be a marker of a new cultural tradition that emerged due to migration, cultural contacts or assimilation of a former aboriginal group (Stratanovich 1977). While Stratanovich's assumption has not been thoroughly verified or confirmed by other folklorists or anthropologists, historical linguistics nevertheless testifies in favor of his theory: according to recent findings in the history of Viet-Muong languages, once (probably at the turn of the Common Era) the Viet-Muong speakers migrated to the area of what is now northern Vietnam from the mountain regions of eastern Laos and interacted here with Taic and other aboriginal peoples before being influenced by the Chinese (Nguyễn Tài Cẩn 1995).

${ }^{19}$ In the Thanh Hóa variant of Muong epics, Dịt Dàng is born from the first of twelve eggs laid by birds-progenitors, and therefore appears to be Tá Cần's brother. Here he is merely one of the first rulers (lang cun), along with several others, not the main culture hero as in the other versions of the epic cycle.

${ }^{20}$ According to modern spelling rules, the word 'bat' in Vietnamese should be written as Doi, not Gioi. 
${ }^{21}$ All these trees are valuable timber trees. Lim tree is Erythrophleum fordii, found in southeastern China, Taiwan, and Vietnam; Melia azedarach is a tree of Meliaceae family; Dracontomelon is a genus of flowering trees in the family Anacardiaceae; it is a common urban tree in Hanoi.

${ }^{22}$ Aganonerion polymorphum is a plant native to Indochina (Thailand, Laos, Cambodia, Vietnam), genus in the dogbane family Apocynaceae.

${ }^{23}$ The motif of acquisition of sericulture and silk weaving is not found in the Thanh Hóa variant of the Muong epics.

${ }^{24}$ Two terms, 'Cun' and 'Lang', or their combination, 'Lang Cun', are used in epic tales to designate the rulers' titles in the uplands settlements. The king Dịt Dàng's title in the Hòa Bình and Sơn La variants of the Muong epics is termed as vua/bua, i.e. 'the king'.

${ }^{25}$ Raglan 1990 [1936]: 89-165.

\section{REFERENCES}

Ben-Amos, Dan 1980. The Concept of Motif in Folklore. In: Venetia J. Newall (ed.) Folklore Studies in the Twentieth Century: Proceedings of the Centenary Conference of the Folklore Society. Woodbridge, UK: D.S. Brewer \& Totowa, NJ: Rowman and Littlefield, pp. 17-36.

Ben-Amos, Dan 1995. Are There Any Motifs in Folklore? In: Frank Trommler (ed.) Thematics Reconsidered: Essays in Honor of Horst S. Daemmrich. Amsterdam \& Atlanta: Rodopi, pp. 71-85.

Bùi Huy Vọng 2010. Tang Lễ Cổ Truyền Nguòi Muòng. [Muong Traditional Funeral Rites.] Hà Nội: NXB Đại Học Quốc Gia.

Bùi Huy Vọng 2015. Văn hóa dân gian Mưòng: Một góc nhìn. [Muong Folk Culture: A View.] Hà Nội: NXB Khoa Học Xã Hội.

Campbell, Joseph 2004 [1949]. The Hero with a Thousand Faces. Princeton: Princeton University Press.

Census $2010=$ The 2009 Vietnam Population and Housing Census: Completed Results. Hà Nội: The Central Population and Housing Census Steering Committee.

Cuisinier, Jeanne 1946. Les Muòng: géographie humaine et sociologie. Paris: Institut d'Ethnologie.

Daemmrich, Horst S. 1985. Themes and Motifs in Literature: Approaches - Trends Definition. The German Quarterly, Vol. 58, No. 4, pp. 566-575. http://dx.doi. org/10.2307/406945.

Đặng Văn Tu 1988. Cây si trong văn nghệ dân gian. [Benjamin Fig Tree in Folklore.] In: Nguyễn Từ Chi (ed.) Nguòi Muoòng vói văn hoá cổ truyền Muoòng Bi. [Muong People with Traditional Muong Bi Culture.] Hà Sơn Bình: UBND Huyện Tân Lạc, Sở VHTT, pp. 146-156.

ĐĐĐN 1974 = Đẻ Đất Đé Nưóc. Truyền thuyết dân tộc Muòng. [The Birth of the Earth and Water: Legends of the Muong People.] Nguyễn Từ Chi and Nguyễn Trần Đản. Hà Nội: NXB Kim Đồng. 
ĐĐĐN 1975 = Đẻ Đất Đẻ Nước. Sủ Thi dan tộc Muoòng. [The Birth of the Earth and Water: The Muong Epics.] Thanh Hóa: Ty Văn Hóa Thanh Hóa - Tiểu Ban Văn Nghệ Dân Gian.

ĐĐĐN 1976 = Đẻ Đất Đẻ Nưóc. Tho dân gian dan tộc Mưòng. [The Birth of the Earth and Water: The Muong Folk Poetry.] Hà Nội: NXB Văn Học.

ĐĐĐN 1988 = ĐéĐát Đé Nước. Sủ Thi Muòng. [The Birth of the Earth and Water: The Muong Epics.] Đặng Văn Lung, Vương Anh, Hoàng Anh Nhân. Hà Nội: NXB Khoa Học Xã Hội.

ĐĐĐN 2005 = Mo kể chuyện Đẻ Đất Đẻ Nuoóc (Song ngũ Muòng - Việt). [Mo-Master Is Telling Stories of the Birth of the Earth and Water (Parallel Texts in Muong and Vietnamese).] Đinh Văn Ân (Sưu tầm và dịch). Hà Nội: NXB Văn hóa dân tộc.

Dundes, Alan 1962. From Etic to Emic Units in the Structural Study of Folktales. The Journal of American Folklore, Vol. 75, No. 296, pp. 95-105. http://dx.doi. org/10.2307/538171.

Dundes, Alan 1997. The Motif-Index and the Tale Type Index: A Critique. Journal of Folklore Research, Vol. 34, No. 3, pp. 195-202. Available at https://www.jstor.org/ stable/3814885?seq=1\#page_scan_tab_contents, last accessed on 12 March 2019.

Grossin, Pierre 1926. La province Muong de Hoa-Binh. Hanoi: La Revue Indochinoise.

Kelley, Liam C. 2012. The Biography of the Hồng Bàng Clan as a Medieval Vietnamese Invented Tradition. Journal of Vietnamese Studies, Vol. 7, No. 2, pp. 87-130. DOI: $10.1525 / v s .2012 .7 .2 .87$.

Kelley, Liam C. 2015. Inventing Traditions in Fifteenth-Century Vietnam. In: V. Mair \& L. Kelley (eds.) Imperial China and Its Southern Neighbours. Singapore: Institute of Southeast Asian Studies, pp. 161-192.

Lĩnh Nam Chích Quái 2001 = Lĩnh Nam chích quái: truyện cổ dân gian suu tập biên soạn $o ̛$ thế $k \dot{y} X V$. [Selection of Wondrous Tales of Linh Nam: Folktales Collected and Compiled in the Fifteenth Century.] Compiled by Vũ Quỳnh \& Kiều Phú; edited by Đinh Gia Khánh. Hà Nội: Văn học.

Meletinskii, Eleazar 1984. Ob arkhetipe intsesta $\mathrm{v}$ fol'klornoi traditsii (osobenno v geroicheskom mife). [On the Archetype of Incest in Oral Tradition (Especially in Heroic Epos).] In: B. Putilov (ed.) Fol'klor i etnografiia: U etnograficheskikh istokov fol'klornykh siuzhetov i obrazov. [Folklore and Ethnography: At the Ethnographic Origins of Themes and Images in Folklore.] Leningrad: Nauka, pp. 57-62.

Mo Muòng Hòa Bình 2011. [Ritual Narratives of the Muong from the Province of Hòa Bình.] Hòa Bình: Ủy Ban Nhân dân Tỉnh Hòa Bình.

Nekliudov, Sergei 2004. Motiv i tekst. [Motif and Text.] In: S. Tolstaia (ed.) Iazyk kul'tury: Semantika i grammatika. [Language of Culture: Semantics and Grammar.] Moscow: Indrik, pp. 236-247. Available at http://inslav.ru/images/ stories/pdf/2004_Jazyk_kul\%27tury_semantika_i_grammatika.pdf, last accessed on 12 March 2019.

Nguyễn Tài Cẩn 1995. Giáo trình lịch sủ ngũu âm tiếng Việt (so thảo). [Textbook of Vietnamese Historical Phonology (Draft).] NXB Giáo dục.

Nguyễn Từ Chi 1997. La Cosmologie Muong. Paris: L'Harmattan. 
Nikulin, Nikolai 1985. Mifo-epicheskie skazaniia narodov V'etnama. [Myths and Epics of Vietnam.] In: S. Nekliudov (ed.) Spetsifika zhanrov v literaturakh Tsentral'noi $i$ Vostochnoi Azii. Couremennost'i klassicheskoe nasledie. [The Specifics of Genres in the Literatures of Central and Eastern Asia: Modernity and Classic Heritage.] Moscow: Nauka, pp. 7-38.

Nikulin, Nikolai 1995. V'eto-myongskii mif o mirovom dreve i stanovlenie literatury. [The Viet-Muongian Myth of the World Tree and the Formation of Literature.] In: E. Kotliar \& B. Riftin (eds.) Mifologiia i literatury Vostoka. [Mythology and Literatures of the Orient.] Moscow: Nasledie, pp. 126-147.

Nikulin, Nikolai 1996. Arkhaicheskii epos narodov V'etnama. [Archaic Epics of Vietnam.] In: N. Nikulin (ed.) Epos narodov Zarubezhnoi Azii i Afriki. [Epics of Foreign Countries of Asia and Africa.] Moscow: Nasledie, pp. 127-185.

Oppenheimer, Stephen 1998. Eden in the East: The Drowned Continent of Southeast Asia. London: Phoenix.

Phùng, Huyền Trang 2015. Cây Si trong đời sống tinh thần của người Mường. Báo Phú Tho diẹn tủ. [The Tree of $S i$ in the Spiritual Life of the Muong. Phú Thọ, Online Paper.] 21 March. Available at http://baophutho.vn/van-hoa/201503/cay-si-trongdoi-song-tinh-than-cua-nguoi-muong-130141, last accessed on 12 March 2019.

Raglan, Lord 1990 [1936]. The Hero: A Study in Tradition, Myth, and Drama. In: Robert Segal \& Alan Dundes \& Lord Raglan \& Otto Rank. In Quest of the Hero. Princeton: Princeton University Press, pp. 89-175.

Rank, Otto 1990 [1909 in German]. The Myth of the Birth of the Hero. In: Robert Segal \& Alan Dundes \& Lord Raglan \& Otto Rank. In Quest of the Hero. Princeton: Princeton University Press, pp. 2-87.

Stratanovich, Grigorij 1977. Etnogeneticheskie mify ob iskhode iz iaitsa ili tykvy u narodov Iugo-Vostochnoi Azii. [Ethnogenetic Myths on Origin from Egg or from Gourd among the Peoples of Southeast Asia.] In: R. Lipec (ed.) Etnicheskaia istoriia $i$ fol'klor. [Ethnic History and Folklore.] Moscow: Nauka, pp. 62-73.

Taylor, Keith 2001. On Being Muonged. Asian Ethnicity, Vol. 2, No. 1, pp. 25-34. http:// dx.doi.org/10.1080/14631360120017997.

Thompson, Stith 1955-1958. Motif-Index of Folk Literature: A Classification of Narrative Elements in Folktales, Ballads, Myths, Fables, Mediaeval Romances, Exempla, Fabliaux, Jest-Books, and Local Legends. Revised and enlarged edition. Bloomington: Indiana University Press. Available at https://sites.ualberta.ca/ urban/ Projects/English/Motif_Index.htm, last accessed on 7 March 2019.

Trương Sĩ Hùng 1992. Sủ Thi Thần Thoại Muoòng. [Muong Mythic Epics.] Hà Nội: NXB Văn hóa dân tộc - Viện Đông Nam Á.

Veselovskii, Alexander 1989 [1940]. Poetika siuzhetov. [Poetics of Plots.] In: A.N. Veselovski (comp.) Istoricheskaia poetika. [Historical Poetics.] Moscow: Vysshaia shkola, pp. 300-306. Available at http://biblio.imli.ru/images/abook/ teoriya/Veselovskij_A._N._Istoricheskaya_poetika._1989.pdf, last accessed on 12 March 2019. 


\title{
THE TRAVELLING GIRL AND HER HELPFUL SIBLINGS: AN UNNOTICED BOREAL TALE AND THE ATU INDEX
}

\author{
Yuri Berezkin \\ Museum of Anthropology \& Ethnography (Kunstkamera) \\ Russian Academy of Sciences \\ Department of Anthropology \\ European University at St. Petersburg, Russia \\ e-mail: berezkin1@gmail.com
}

\begin{abstract}
After presenting the results of statistical processing of data on the distribution of folklore motifs in Eurasia, the author describes a previously unnoticed tale that is widespread across Northern Asia. The protagonist of the story is a travelling girl who successfully competes with her rival, often a frogwoman. In the beginning, the heroine parts with her brother(s) or sister, taking them for dead or disappeared forever. Later they appear again and demonstrate their supernatural qualities by helping her. Many particular motifs found in the corresponding Siberian narratives have parallels in the New World, though the basic scheme of the plot is not known in America. Unlike the Western and Southern Eurasian and North American oral traditions well systematized by Stith Thompson, Central and Northern Asian traditions were ignored by him and remain severely underrepresented in comparative folklore studies. The tale described in this article is one of the many not registered in international indexes. Limitations of the present-day system of classification of traditional narratives are related to the uncertainty concerning the purpose of their study.
\end{abstract}

Keywords: big data in folklore studies, Finno-Ugric folklore, folklore indexes, Siberian folklore

\section{ADVENTURE AND TRICKSTER MOTIFS IN FOKLORE TEXTS}

Statistical processing of folklore and mythological motifs (i.e., narrative episodes and ideas related to worldview) demonstrate different and independent tendencies of their areal spread in the Old World. The computed motifs belong to several different thematic groups that probably spread in different time periods and under different circumstances. One group includes episodes and images that expose cosmological and etiological ideas. Another group includes 
episodes of adventure and tricks. Inside the latter, three subgroups can be selected. The first one corresponds to situations that are impossible in reality and are usually not comical. Episodes of the second subgroup do not contain supernatural elements and mostly describe swindles, tricks, and other deviant forms of behavior. The protagonists of both subgroups are anthropomorphic. The third subgroup consists mainly of trickster episodes but with zoomorphic protagonists.

These three subgroups of episodes roughly correspond to particular categories of tale types selected by standard folklore indexes based on the ATU (Aarne-Thompson-Uther) system (Aarne \& Thompson 1961; Uther 2004). These are tales of magic, realistic tales (together with tales of the stupid ogre and anecdotes), and animal tales. Uncertain cases are rare and do not influence the statistical tendencies of the distribution of many hundreds of motifs in hundreds of traditions. However, computing the data of ATU turned out to be impossible. The main reason is that the definitions of most of the tale types provided by this index are not unambiguous enough and often merge two and more episodes under one title, despite the fact that such episodes have different areal distribution (Berezkin 2015). This is not surprising because ATU was never conceived to serve a database for statistical operations. Therefore, we had to create our own system of classification for computing the data, i.e., the electronic catalogue of mythology and folklore (Berezkin \& Duvakin n.d.). This catalogue currently includes abstracts of more than 55,000 texts and contains information on the spread of more than 2,500 ideas related to worldview, and narrative episodes across the whole world, from South Africa to Tierra del Fuego.

The "international" tale type system of ATU was created and elaborated using European, Near Eastern, North African, and South Asian folklore materials, while the Siberian and part of the Central Asian data were practically ignored (Aarne \& Thompson 1961; Thompson 1946). The farther away from Europe and the Near East, the lesser number of the tale types that are recognized by ATU are found in traditional narratives, while there appear ever more types that do not have correspondences in ATU. However, the grouping of the narrative units into episodes of adventure (mostly with supernatural elements), trickster episodes with anthropomorphic protagonists, and trickster episodes with zoomorphic protagonists is largely preserved. Only in the New World, the very opposition between zoo- and anthropomorphic actors, as well as between the supernatural and the real, becomes irrelevant (historical legends standing, of course, apart). 


\section{FACTOR ANALYSIS USED FOR COMPUTING THE DATA}

The results of a quantitative approach to folklore data depend not only on the system of classification of the initial material but also on the choice of particular statistical programs. The program that is used here is the so-called factor analysis, which is a way to reduce a contradictory and extremely complex picture (in our case, the distribution of motifs in hundreds of traditions) to a few clear and understandable tendencies.

In digitized form, our world folklore and mythology database is a binary table (it consists of zeros and ones), with lines for traditions and columns for motifs (i.e., images and episodes). Every tradition is characterized mathematically by long strings of zeroes and ones, representing the absence and presence, respectively, of particular motifs. The extent to which any sets of traditions are similar to each other is a function of the degrees of similarity (correlation) between their representative strings. The strings of zeros and ones are considered to form vectors in a high-dimensional space of motifs. One considers this space to be spanned by underlying, hidden factors or components. Applying particular mathematical procedures, we reduce this set of many different tendencies that cannot be grasped by our brain, to a few major tendencies. The latter are represented by the so-called principal components (PC).

The first PC accounts for the largest possible amount of variability in the data - and thus contains the largest amount of information about the differences between traditions. The next PC has the next highest variance (and information about differences) but is uncorrelated with the first PC, i.e., independent from it. Practically, it means that each PC selects a particular group of traditions that contains the most similar sets of motifs, i.e., shares the biggest number of identical narrative episodes. Concurrently, the corresponding PC selects another group of traditions that contains a set of such narrative episodes that are most different from the episodes typical for the first group. Mathematical indexes for traditions of these two groups selected by the corresponding PC are opposite (one negative and another positive).

Only the first two, three or maximum four PCs reveal tendencies that are relevant for all the computed units, in our case for all selected traditions of Eurasia and North Africa. Other PCs reveal similarity/dissimilarity between traditions on the local level. These two, three or four PCs account for a small proportion of the variances - less (sometimes much less) than $20 \%$ of the total. However, exactly this information is of crucial importance for the research. All the rest is related to a great number of different minor (and often chaotic) tendencies produced thanks to exclusive links between particular traditions and their small groups. 
It should be underlined once again that the tendencies in the distribution of particular narrative episodes revealed by different PCs are independent from each other. Each PC reveals its own pattern of the geographical spread of selected traditions based on the similarity/dissimilarity between them. Each such pattern is most probably related to a particular historical process that took place at a particular time.

\section{THE COMPUTING OF AREAL DISTRIBUTION OF FOLKLORE MOTIFS REVEALS THE NORTHERN AND THE SOUTHERN INTERACTION SPHERES IN EURASIA}

When it comes to computing adventure motifs, the implementation of the 3rd PC for examining the areal distribution of motives demonstrates a difference between the forest and tundra zone of Northern Eurasia and the more southern, or better say, southwestern, regions (Fig. 1). Traditions of Northern Eurasia from the Baltic region to the Sea of Japan share a certain amount of common motifs, while southern traditions from Portugal and Morocco to South Asia share another set of common motifs, which is different from the northern one. The northern zone in its western fringe extends up to the Baltic and its weaker margin encompasses Central Europe and Scandinavia. The highest mathematical indexes (above +3.00 ), i.e., the biggest numbers of corresponding motifs, are for the Nanai, Sakha, Russians, Udeghe, and Chukchi, followed by the Buryats, Mansi, Baikal Evenks, Tundra Samoyeds, Lithuanians, Mari, and Bashkirs. The opposite (Mediterranean - South Asian) southern set of motifs is best represented in the Near East and the adjacent areas among the Persians, Turks, Arabs of Syria, Arabs of Egypt, Armenians, Azeris, and Arabs of Iraq (indexes below -2.00).

The East Asian traditions are mostly neutral, i.e., they contain fewer motifs typical for either of the sets or a mixture of both. The southern area largely corresponds to the folklore of the "western civilization" (or "The Folktale from Ireland to India"), as Stith Thompson named it in contrast to "The Folktale among a Primitive People" (Thompson 1946: vii, 14).

The results of the computing of another subgroup of motifs also evidence in favor of the existence of the northern/southern dichotomy in the distribution of folklore motifs in Eurasia - I mean trickster episodes with animal protagonists. Here one of the main PCs (the 2nd PC) again selects the northern interaction sphere that extends from the Baltic to the Pacific with a margin that includes 


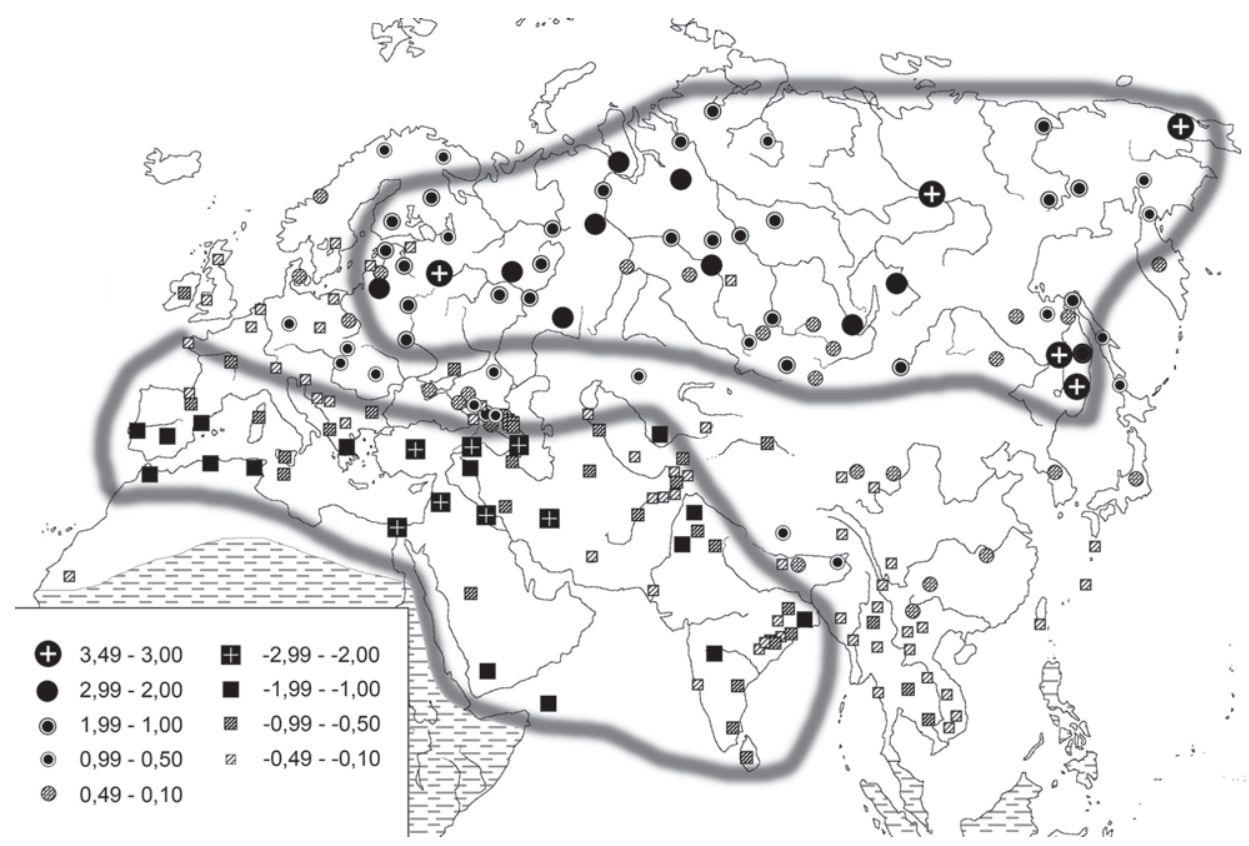

Figure 1. Data on the distribution of 605 episodes of adventure in 290 traditions of Eurasia and Northern Africa, third PC, dispersion (i.e., percent of total information, see explanation in text) 3.0\%. Data from shaded areas (in Africa and Southeast Asia) are not computed. Traditions with mathematical indexes close to zero (from 0.09 to -0.09) are not in the chart (they are neutral in respect to the basic tendencies). Areas with the maximum concentration of motifs typical for the northern and southern (MediterraneanSouth Asian) sets are ringed with a blurred line.

Central Europe, Scotland, and Scandinavia (Fig. 2). The opposite southern zone includes Northern Africa, the Near East, Iran, and South Asia. It does not completely overlap with the southern zone in the distribution of the adventure episodes (Fig. 1), the major difference being the southern and not northern affiliation of the steppe traditions of Central Asia. However, the configuration of the northern (forest and tundra) zone in both cases is very similar. Such a correlation does not happen often and probably means that in Northern Eurasia, episodes of adventure and episodes of animal tales spread because of the same historical circumstances. 


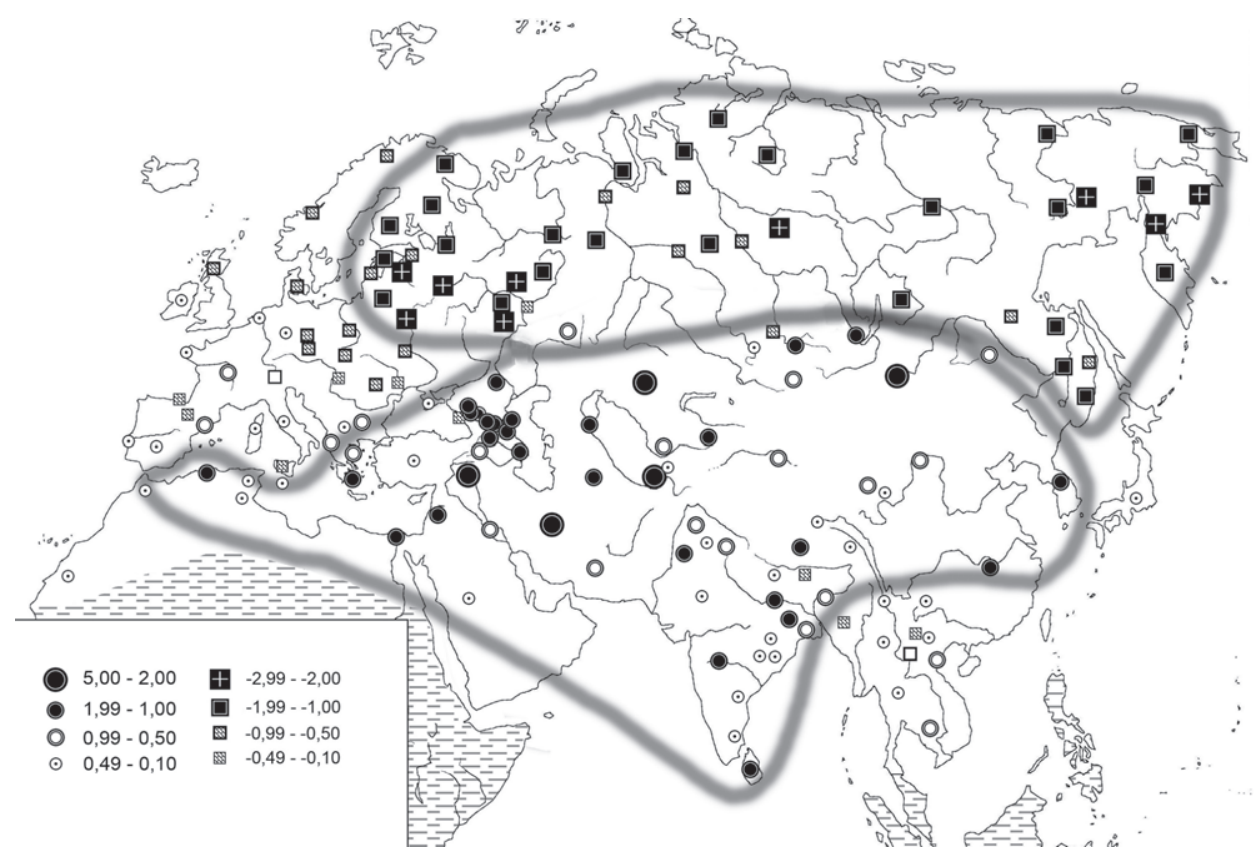

Figure 2. Data on the distribution of 605 episodes of animal tales in 266 traditions of Eurasia and Northern Africa, second PC, dispersion (i.e., percent of total information, see explanation in text) 4.3\%. For other explanations see caption for Figure 1.

\section{STORIES ABOUT THE TRAVELLING GIRL AND HER HELPFUL SIBLINGS}

The series of narratives presented below is one of several tales responsible for the statistical tendencies described above and it has never been selected as a particular analytical unit by scholars. The corresponding narratives provisionally named "The travelling girl and her helpful siblings" have been recorded from Sakhalin to Ural with isolated and only partial analogies in Northeastern Europe from the Middle Volga to the Kola Peninsula (Fig. 3).

The protagonist is a girl opposed to an imposter (often a female frog). The girl has brothers (a brother, a sister) whom she must leave. She takes them for dead or lost forever but later they appear again and help her by demonstrating their supernatural qualities. Another common motif is the marriage of the heroine and the imposter followed by episodes in which the heroine demonstrates her superiority. The particular set of episodes is subject to variations but the 


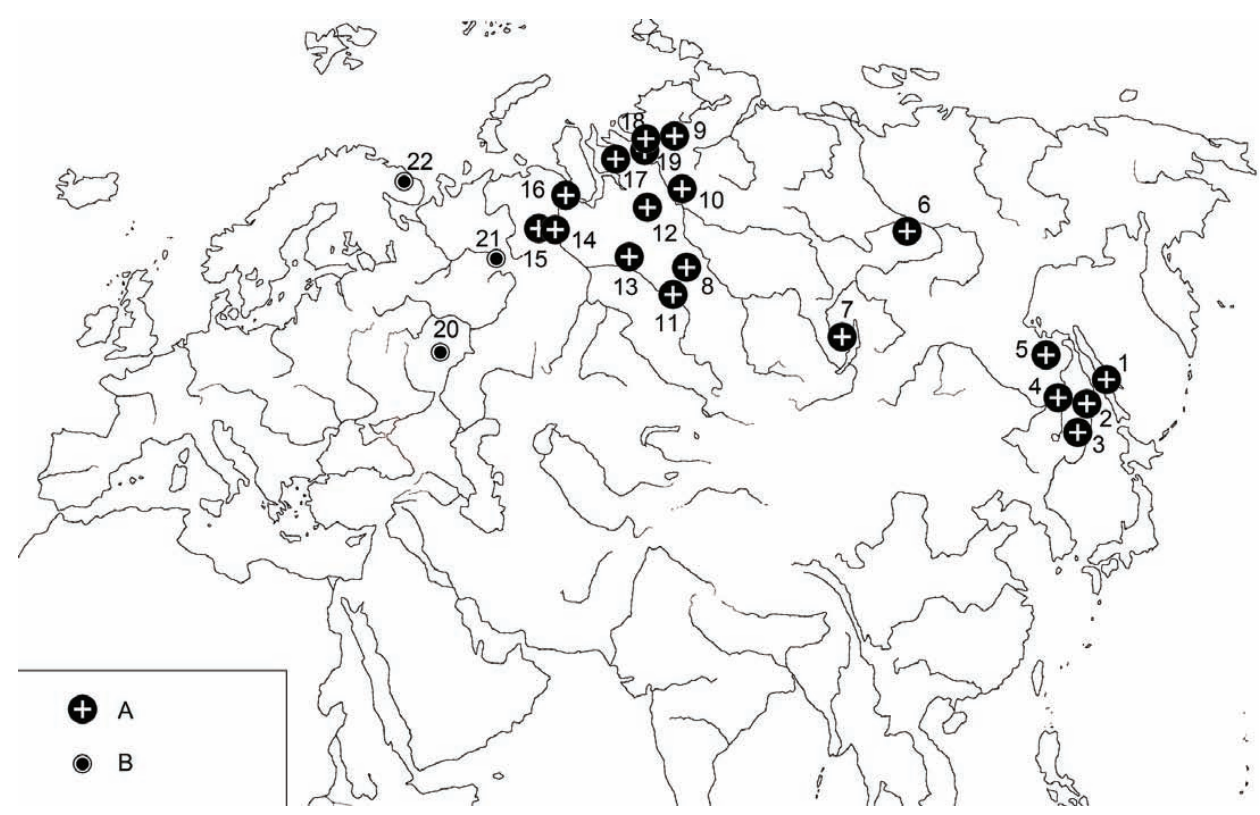

Figure 3. Places where "The travelling girl and her helpful siblings" tale has been recorded. A. Typical (Siberian and Far Eastern) variants. B. European variants. 1. Uilta. 2. Nanai. 3. Oroch. 4. Udeghe. 5. Negidal. 6. Sakha (precise place of recording not specified). 7. Cis-Baikal Evenks. 8. Sym Evenks. 9. Nganasan. 10. Ket. 11. Southern Selkup. 12. Northern Selkup. 13. Eastern Khanty. 14. Northern Khanty. 15. Northern Mansi. 16. Obdorsk Samoyed. 17. Gydan Samoyed. 18. Taimyr Samoyed. B. European variants only partly related to Siberian ones. 19. Komi. 20. Mordvinians. 21. Sami.

common motifs are easily recognized. It should be underlined that the conflict with the imposter does not bring much harm to the heroine. In this respect, the corresponding series of texts are different from such tale types as ATU 403 (The Black and the White Bride), 404 (The Substituted Bride), and other variants in which the heroine is humiliated by her antagonist or even killed.

Partial parallels for North Eurasian texts about the travelling girl or two girls are found in America and across the Asian-Oceanic Pacific rim. However, analogies are completely absent in Africa, across most of Eurasia, in the northeast of Asia, as well as in American Arctic and Subarctic (there is only one distantly related text among the Denaina Athabascans). Such a distribution is typical of motifs brought to America at the (relatively) early stages of its peopling, i.e., before the appearance of the Paleo-Eskimo culture in Alaska (4th millennium BC) (Anderson 2004; Dumond 2005: 28) and probably before the spread of the Paleoasiatic languages in Chukotka and the Na-Dene languages in American Subarctic (Berezkin 2019). 


\section{PARALLELS OF PARTICULAR MOTIFS IN THE SIBERIAN STORIES IN AMERICA}

Many particular motifs of the Siberian "Travelling girl and her helpful siblings" tale, which are used in its different versions, are found among North (and even South) American Indians. It is enough to name but the most obvious parallels. 1. Two women have children, one kills the other and promises to feed her children the meat of the victim's children; the victim's children escape. 2. People shoot arrows, which hit each other's ends and form a chain (rope, ladder) by means of which they climb to the sky (Fig. 4). 3. Being provoked or forced by another, a person slides down a hill and dies or gets into trouble (falls on a sharp pole, into the water, etc.) (Fig. 5). 4. Two sisters or companions are travelling and ultimately get married, one of them being cleverer and more successful than the other. 5. Running away from a dangerous being, a person throws a comb that turns into a thicket, and a whetstone that turns into a mountain (the whetstone is especially worth noticing; Fig. 6). 6. A person stretches his or her leg as a bridge across a water body. 7. A baby boy is thrown into the river but is ultimately lured to the shore and comes to live among people. 8 . The girl and the frog are two daughters-in-law. Subject to a series of tests, one demonstrates her good and the other her bad qualities (Fig. 7).

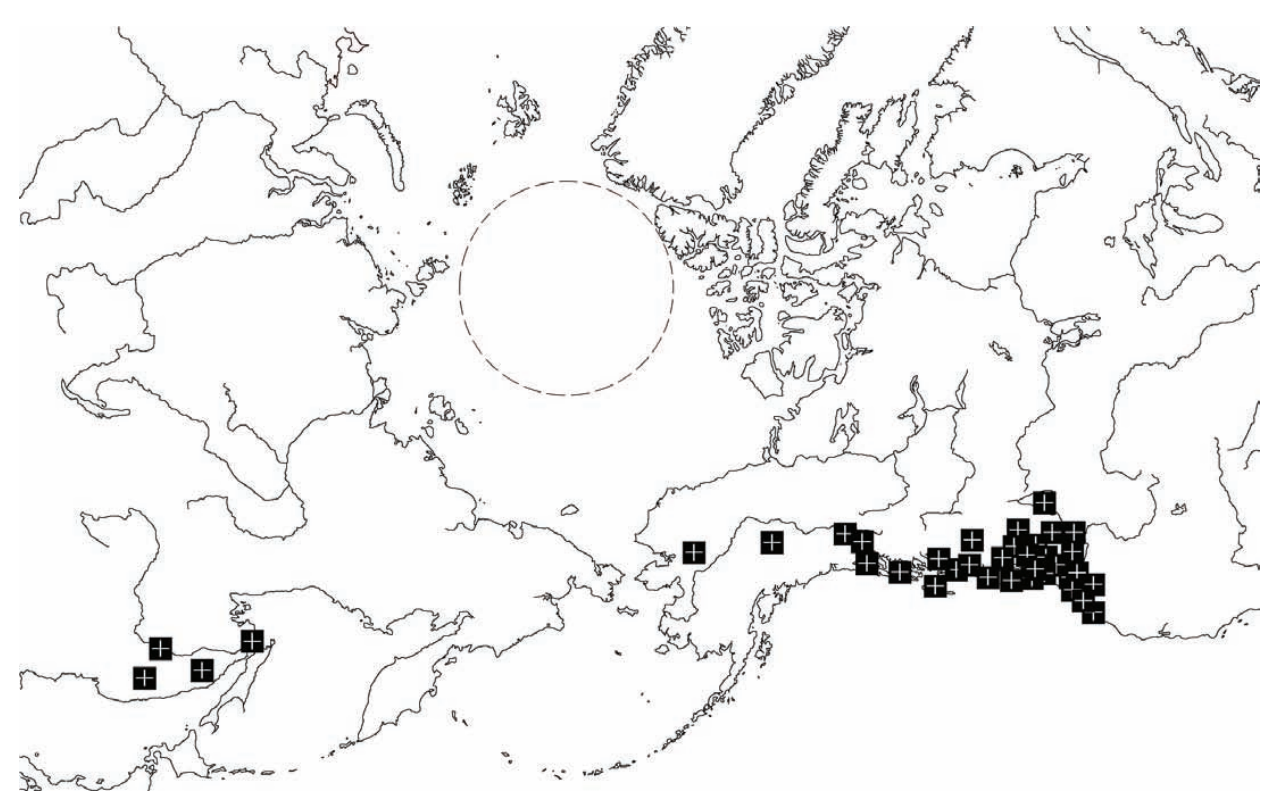

Figure 4. Spread of the motif "Chain of arrows". People shoot arrows, which hit each other's ends, forming a chain (rope, ladder), and climb up this chain to the sky. 


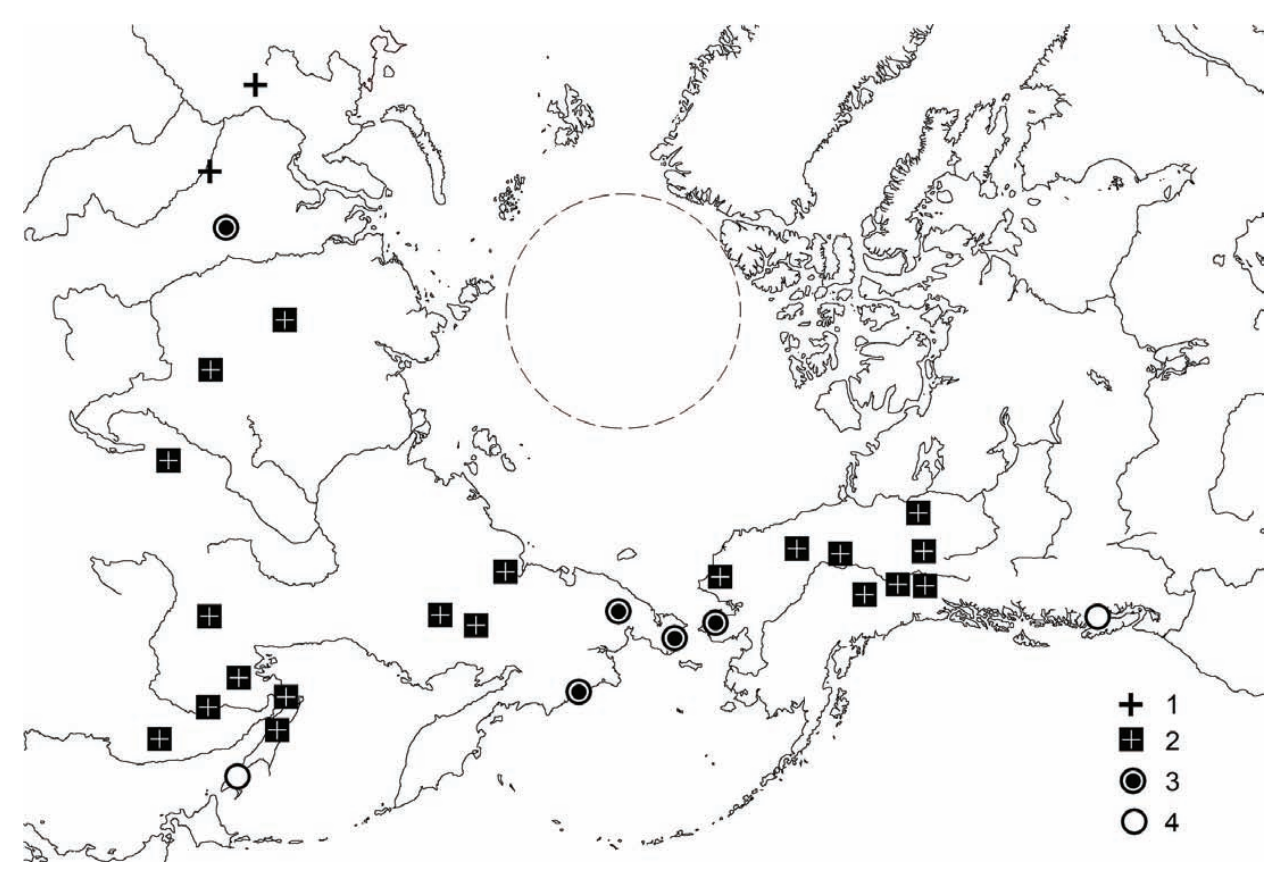

Figure 5. Spread of the motif "Sliding downhill". 1. A person tricks another to slide down a hill, rides behind and kills the other, cutting her with a sledge or skis. 2. A person tricks another to slide down a hill and kills them, putting sharp poles, knives, etc., on the way. 3. Being thoughtless or provoked by another, a person rides down a hill and falls into the water. 4. Provoked by another, a person rides down a hill and falls into a precipice.

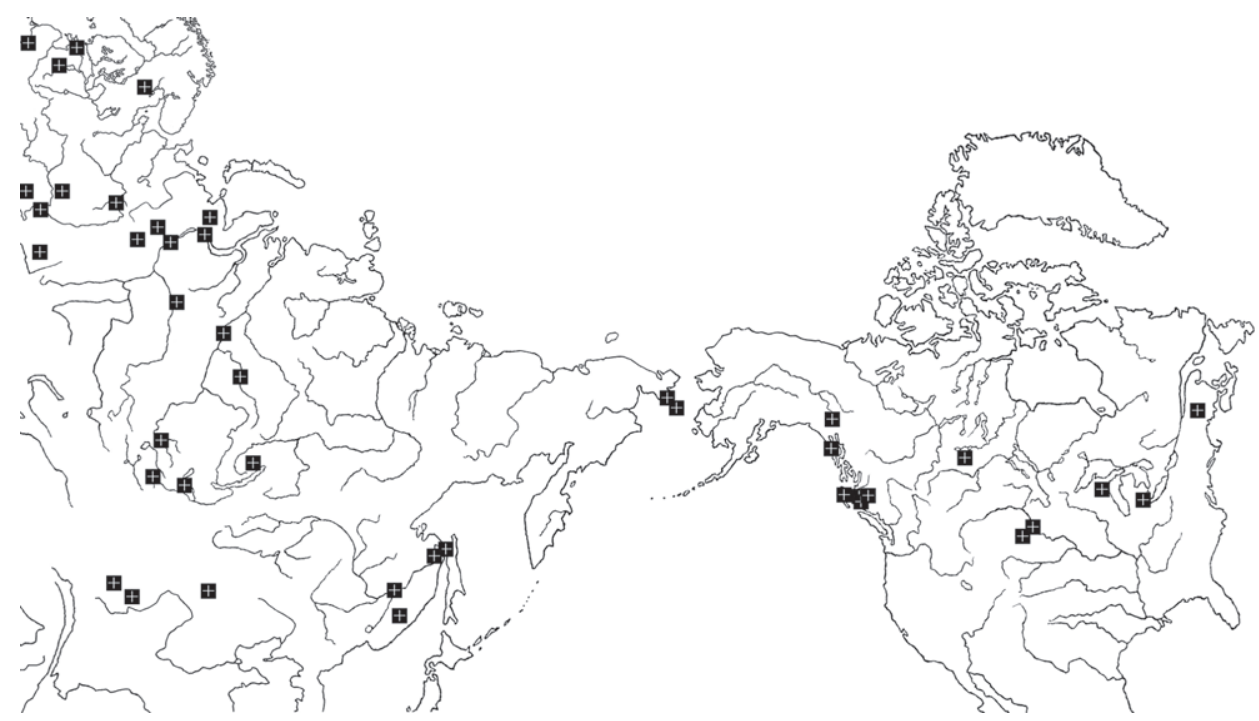

Figure 6. Spread of the motif "Thrown whetstone turns into mountain". Pursued by a dangerous being, a person throws objects that turn into mighty obstacles on the way of the pursuer. One of the objects is a whetstone, which turns into a mountain. 


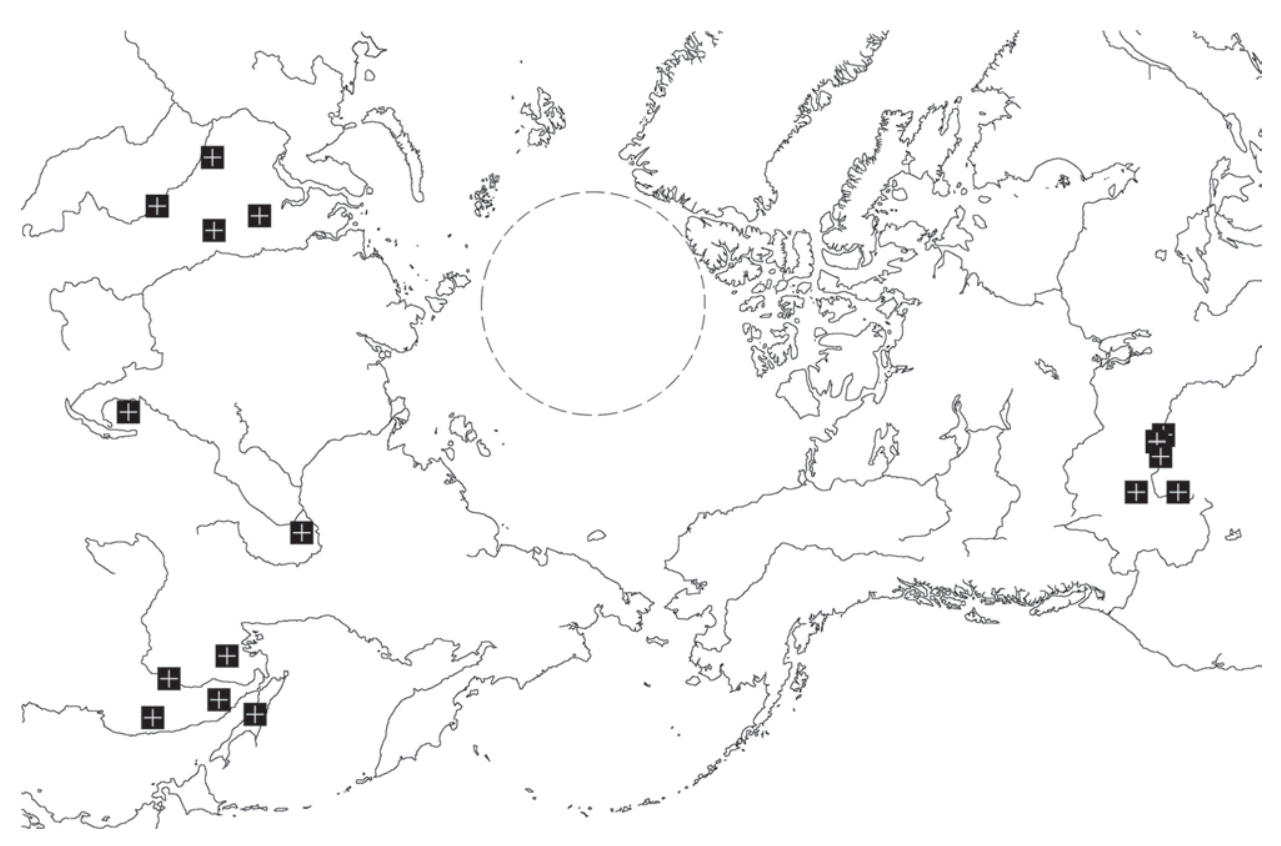

Figure 7. Spread of the motif "Two sisters-in-law, the girl and the frog". One brother marries a girl, another a frog or a toad, or one man takes two wives, a woman and a frog. Both wives have to pass a test. The values of the girl are highly assessed; the frog's poor qualities are revealed.

Some of these motifs have a continuous Siberian-North American spread but others are absent across Asian northeast and American northwest, which excludes their slow diffusion across the Bering Strait during the last millennia. In some of the Northern Eurasian texts, the concentration of motifs that have American parallels is so high that such narratives would not look alien in British Columbia or even Montana.

Narratives described in this article have some vague parallels not only in America but also to the west of the Urals. The heroine's brothers, with whom she parted during her journey to the house of her husband (among the Komi and Sami), or the heroine's sister who lives in the sky and helps her (among the Mordvinians, with more remote parallels among the Mari) remind of the heroin's siblings in Siberian versions. To the west of the Urals, these motifs may have been brought by the Finno-Ugrians, although an earlier time of their westward spread is also feasible. It seems that possible Siberian parallels in the European versions have been obliterated by the motifs that are typical of "international" fairy tales. In the European versions, the latter motifs predominate. 


\section{REVIEW OF THE STORIES ABOUT THE TRAVELLING GIRL}

Below follows a review of some typical texts about the travelling girl and her helpful siblings.

Orochs. During a game, seven brothers hurt a squirrel. The squirrel promises revenge. Brothers hide their sister under the hearth, putting a bag with blood above her. They shoot arrows into the sky that hit each other and form a ladder. Brothers climb it and disappear into the sky. An old shoe tells the squirrels where the girl is hidden. The squirrels poke the hearth, see the blood, decide that the girl is killed, and go away. The girl sets off in search of her brothers and comes to a frog. The frog takes her clothes off and the girl hides inside a stick. Two men come, the older one sits down near the frog, the younger one near the stick, whittles it, blood appears. When he comes again to pick up his forgotten knife he finds the girl instead of the stick. Both men bring their wives home. Being asked to show their kinfolk, the frog brings other frogs, and the father-in-law drives her out. The girl calls her brothers, they descend to the earth, give their sister good garments and return to the sky (Margaritov 1888: 29, another variant in Arsenyev 1995: 122-125).

Variants recorded among the Udeghe (Lebedeva et al. 1998: 225-235, 474476, No. 31, 107), Uilta (Voskoboinikov \& Menovschikov 1951: 373-376), Nanai (Khodzher 2011: 67-77) and Neghidals (Tsintsius 1982: 135-139, No. 25) are similar to the Oroch versions in all major episodes, although the Uilta and the Neghidal texts lack the initial part about a conflict with cannibal squirrels. Some variants contain very detailed descriptions of the competition between the girl and the frog in the house of their father-in-law.

Sakha (Yakuts). Two sisters come across a stone that looks like a person, bring it home and put it into a cradle. The stone turns into a baby. Coming home, the sisters find roasted fish. The younger one turns into a piece of bark and remains home. She sees how the baby extracts fish from his mouth, roasts it, promises to devour the sisters and returns into his cradle. Sisters put a hot pot over the baby and run away. An old woman stretches her leg across the river and the girls cross the river by this bridge. When the demon steps on the old woman's leg, she takes it away and he drowns. The sisters come to a female monster who has one leg and one arm and who imprisons them in a chamber. The younger sister turns into a needle and gets out through a crack in the chamber's wall. The elder one inserts her head into the same crack but is stuck. The younger one pulls the head, tears it off and takes it with her. The head begins to weep when the younger sister attempts to abandon it at a larch or at a birch but is satisfied with being put in a tree that was struck by lightning. The girl comes 
to a house of silver where a female frog lives. The frog asks the girl to make clothes for her husband and hides her from him. The husband understands that the frog could not have done such perfect work, finds the girl and marries her, asks both wives to bring presents from their kinfolk. The frog brings leeches and worms. The girl comes to the tree where she had abandoned her sister's head. She finds her sister intact and alive, living in a nice house and having plenty of cattle. Her husband is Thunder and he gives some cattle to his sister-in-law. The girl's husband kills the worms and leeches brought by the frog and asks the frog to spend a night on the roof of the house. The frog is frozen to death (Vitashevski 1912: 459-465).

The Evenk text from Karama village (Cis-Baikal region) is basically similar to the Sakha version but with a magic flight instead of the leg-bridge episode. Pursued by a monster, the elder sister throws a handkerchief (it turns into a sea) and a comb (a thicket). Then she throws a whetstone but it falls in front of the sisters and becomes a mountain. The younger sister turns into a hair, finds a small hole and comes out from the other side of the mountain. The elder girl becomes an ant, crawls into the hole and gets stuck. The monster swallows the lower part of her body and the younger sister drags out the upper part. Thunder is not mentioned as the husband of the elder sister and it is only said that the heroine got many reindeer from her sister (Titov 1936: 179-181, No. 9-10).

All versions recorded across Western Siberia combine "Travelling girl and her helpful siblings" with the story in which a woman is devoured by a witch but her two daughters escape. Corresponding tales are recorded among the Sym Evenki (Lukina 2004: 75-77, No. 3.18; Vasilevich 1936: 22-24, No. 21, 22), Kets (Kryukova 2013: 202-213), Nganasans (Porotova 1980: 13-19), Northern and Southern Selkups (Pukhnachev 1966: 20-24; Tuchkova 2004: 208-209), Eastern and Northern Khanty (Baulo 2005: 236-239, No. 1; Koptelov 1950: 175-180; Lukina 1990: 101-104, No. 28; Nikolaeva 1999: 133-137, No. 1), Northern Mansi (Kupriyanova 1960: 109-112; Kuzakova 1994: 110-112; Lukina 1990: 334-336, No. 128; Rombandeeva 2005: 289-301, No. 41) and Tundra Nenets (Golovnev 2004: 248-251; Lehtisalo 1947: 147-165, No. 51; Neniang 1997: 61-64).

The lack of space does not permit me to describe two dozen texts; therefore, I shortly retell only three sample versions. The Selkup versions are probably the least detailed, while the Ket and Mansi ones are the richest.

Kets (Kureika River, recorded by Andrei Dul'zon). Hun has a little boy and two girls older than the boy, Kolbassam has her own children. Hun and Kolbassam go to cut the grass, Kolbassam sticks a sharp bone into Hun's ear and brings the body home, covering it with grass. Hun's children notice their mother's braids. They hear Kolbassam say that the next day her children will eat small 
eyes, and she will eat big ones. The boy closes the smoke hole with a cloth full of holes, so that Kolbassam thinks it is still a starry night. The children ask house objects not to betray them if Kolbassam comes and asks where Hun's children went. Kolbassam asks the ladle and the frame of the hearth where the children are. They respond that they were well fed, do not speak. The glue jar betrays the children. Kolbassam sets out in pursuit. A hare, a fox, a wolf, and a bear carry the children on their backs; they are tired. The sisters leave their little brother in a bear's den and reach the river. Their grandmother's tent stands on the other side. The grandmother tells the birch bark to carry the girls across the river and to drown Kolbassam. She tells her granddaughters that two breastbones lie near the ice hole, one with burbot liver and another with marrow; the burbot liver should not be touched. The younger sister does not listen and the devil carries her off. The elder sister (now she is named Hun like her mother) leaves her grandmother. A new Kolbassam jumps out of the stump, suggests searching for lice, puts a sharp bone into Hun's ear, takes her skis. An eagle pulls the bone out, Hun revives, quickly catches up with Kolbassam and takes her skis back. Hun and Kolbassam meet two men, one is the son-prince of the old man Yryt and he marries Kolbassam. Another is the son of an old woman and he marries Hun. The old woman asks Hun to sew a good fell for skies. Hun goes to her brother for glue, glues strong skies, her husband goes to hunt and brings many deer. Kolbassam takes the resin from the "larch uncle", her skies fall apart, the son-prince of the old man Yryt does not get anything. Hun goes to her brother; he asks her husband to put the larch in his house. Her brother's children are bear cubs; they start climbing the larch. Kolbassam brings children of her own brother, they are young pikes, young perches and ides; the old man Yryt accidentally swallows them with water. Kolbassam is killed by thunder. Hun's brother descends from the larch; they begin to live together (Kryukova 2013: 202-213).

Northern Mansi (Khoshlog village). Mosne and Porne live together, each has a daughter and a son. Porne suggests that Mosne slide downhill on wooden skis, slides behind her and crushes her with her iron skis. Mosne's daughter hears how Porne tells her children that they will eat eyes and ears of Mosne's children. Mosne (now the daughter acquires her mother's name) takes her small brother and runs away, throwing a comb (thicket), a flint (flame up to the sky), and a whetstone (mountain). Porne falls behind. Mosne's brother sinks into the ground. Mosne comes to the lake where Porne (i.e. the daughter of the former Porne) invites her to swim, puts on her clothes and gives clothes of bark to her. Mosne forces her to re-exchange the clothes. The son of Toyton-Toyka and the son of Usyn-Otyr-Toyka shoot arrows, Porne grabs the arrow of the son of Toyton-Toyka and marries him. Mosne marries Usyn-Otyr-Toyka's son. She 
goes to the place where her brother disappeared and finds a house. The hostess orders the dogs to lick ice from the guest's feet. Mosne's brother is alive and married but blind in one eye: when he was sinking into the ground, Mosne tried to hold him and accidentally poked his eye. He gives Mosne many reindeer. At home she says that she got an iron chain to encircle the town of her father-inlaw, a copper pot, and a white reindeer. Porne says that she was given a bast rope, half of a clay pot, clothes of bark, and that they harnessed a crucian and a roach. The roach and the crucian go into the ice-hole, the sledges stop, the bast rope breaks, and it is impossible to go far in half of the pot. Mosne's small son says that his uncle's arrow bounces off with a ring, his grandfather's arrow with a thud. Mosne's father-in-law is hurt, goes to war with her brother. Porne suggests removing the sun and the moon from the sky. Mosne attaches luminaries to her sledge, so it becomes dark. After this the father-in-law says he was joking and Mosne puts the luminaries back to the sky (Rombandeeva 2005: 289-301, No. 41).

Tundra Nenets (Gydan Peninsula). Parne and Nenei-ne ("true woman") go to tear grass for insoles. Parne scratches Nenei-ne's face, thrusts her head into the lake and kills her. The victim's daughter sees her mother's earrings in the grass and hears how Parne promises her children to feed them meat of Nenei-ne's children. The girl takes her brother and flees. She throws behind her a board to cut skins (a wooden mountain appears), an iron scraper (an iron mountain), and a flint (an iron ridge). The children ask an old woman to ferry them across the river, praise her face and posture, so that she tells her son to transport them. Parne scolds the old woman's appearance, the old woman's son upsets the boat and Parne sinks. The old woman sends the children out of her house in a boat, and orders them not to look back. The boy disobeys, and branches rip him in half. He (or rather his upper half) asks his sister not to leave him under the boat, near the birch, in the willow, near the larch, explaining that people will come and it will be noisy. He agrees to be left on a sandy hill. The girl's foot falls, she sees seven Parne girls in the hole, runs away; one of the girls catches her and scratches her face. They walk together and meet two men. Parne sits down near the owner of white reindeer, the girl near the owner of black reindeer. After a while, both wives must go home and bring gifts for their husbands. Parne rides to a hole in the ground, returns from the land of seven Parne with a herd of mice. The girl finds her brother alive, he gives her new clothes and reindeer. Parne's husband is furious with her mice, the girl's husband is happy with the gifts. Parne is thrown into the fire, mosquitoes appear from the ashes (Golovnev 2004: 248-251).

The Taimyr version recorded by Kazimir Labanauskas (Neniang 1997: 6164 ) ends with the story of the "thrown-away" boy that has parallels in Siberia 
(the Buryats, Enets, Southern Mansi, Northern and Southern Selkups, Orochs) and considerably more in North America. The heroine gives birth to a boy, the witch replaces him with a half-a-dog and hides under a heap of chips. A birch grows from under the chips, the witch throws it into a lake and says that "water is his father, water is his mother". The woman is abandoned and raises halfa-dog while her son lives in the water. Half-a-dog catches the boy, calls the woman for help. Pieces of ice begin to move from the river towards the house but the boy stops them, advising to throw half-a-dog into the water.

As mentioned above, the European versions contain episodes that are typical of the Eurasian fairy tales and are considerably more different from the Siberian ones than the Siberian versions are from each other.

Komi. Three brothers and a sister bury their mother under the stove, father under the millstone, and go to seek fortune. The elder brother climbs on a silver birch to break silver branches. His sister warns him that he will get stuck and he does stay on the birch. The same happens with the middle and younger brothers (golden birch and pearl birch). The girl comes to the house of the prince, hides under an overturned vat, sings a song about her brothers. The elder and middle sons of the prince cannot find the singer, the younger one finds her. The girl says that she heard him promise to save her brothers. They come to the silver birch, the prince's son waves his sleeve and the boy descends. The same happens with the brothers on gold and silver birches. The girl marries the youngest son of the prince (Plesovski 1975: 15-17).

Mordvinians. After having been in the forest for three years, the old man bends down to drink, Vediava grabs his beard. She refuses to take a stallion, barn, or mill, and demands to give her what the old man does not know he has at home. He comes home and meets his three-year-old daughter. The girl grows up and has one silver tooth. When she goes to Vediava, she covers her tooth with wax. On her way she meets ugly old men, but they do not recognize her. Seeing ugly old women, the girl laughs, the wax falls off, the old men and women run after her. The girl throws a maple comb (maple forest), a whetstone (mountain), and a brush (turns into a tree). The tree grows, the girl climbs it, the old men and women begin to gnaw the trunk. The girl asks her sister to let down a thread from the sky. The sister replies that first she must plow the field, sow hemp, etc. (all kinds of works with hemp enumerated). Finally, she lets down the thread, her sister climbs up to the sky, the tree collapses, the old men and women begin to gnaw each other. In the sky, the sister hides her; the sister's husband is a bear, she sends the bear to carry a chest to her parents. The bear leaves the chest in the yard, the parents find their daughter in it (Yevsevyev 1964: 150-154, No. 18; a similar variant in Paasonen 1941: 282-291). 
Eastern Sami (Kildin dialect, Yokanga River). After the death of their parents, three sons and a daughter are left alone. They go along the river by boat. The girl sees a gilded tree on the shore, asks to stop. The eldest brother says that he will bring a branch himself, goes ashore, and stays there. The episode repeats, all three brothers stay in different places on the shore. The girl goes ashore, follows a rolling spindle, comes to an old man and an old woman. They say that the bride has come to their youngest son. Two elder sons are married, the youngest one marries the girl. The elder daughters-in-law are daughters of a spider. They shut the girl's mouth with a button, push the button with a spindle, make fire under the barn. The old man saves the girl but the elder daughters-in-law say that she ate her own baby. The episode repeats two more times. Two geese and a swan descend, become two boys and a girl, mother and father recognize their children. The spider daughters and their children are told to jump over the fire; they fall into it and burn (Kert 1961: 175-179, No. 44).

\section{SIBERIAN FOLKLORE AND THE ATU SYSTEM}

The stories described above have been recorded across Northern Asia, from Western Siberia to the Far East. They share as many common episodes as European, Near Eastern and Indian sets of texts that belong to particular tale types of the ATU index. "The Travelling Girl" is but one of many tales widespread across Northern as well as Central Asia, which have not found their place in the ATU system (for another example see Berezkin \& Duvakin 2016).

The Northern and Central Asian folklore is rich. The very number of narrative episodes and ideas connected with the worldview, registered in Northern Asia (up to the southern border of Russia) and described in our electronic catalogue, is bigger than in the South Asian traditions. For ten of the best-known Siberian traditions, these numbers are as follows: Buryat - 347, Khakas - 260, Tuvinians of Tuva - 257, Southern Altai - 253, Nanai - 232, Mansi - 226, Chukchi - 219, Central Yakut - 220, Western Tungus - 192, Tundra Nenets - 188. For ten of the best known South Asian traditions the corresponding numbers are smaller: Hindi-speaking people of Uttar Pradesh and adjacent states - 248, Sinhalese 201, Punjabi - 169, Bengali - 162, Santali - 149, Mundari with related Northern Munda groups - 142, Baiga - 128, Marathi - 118, Tamil - 118, Kashmiri - 118.

The difference is proportionally bigger than between the Siberian and the Atlantic European traditions which have been very well described by folklorists. The corresponding numbers for the latter are: French - 431, Portuguese - 367, Norwegian - 294, Irish - 282, Basque - 219, Breton - 169. As we gather additional folklore materials, all these numbers increase but the proportion between 
the regions does not change. However, unlike the South Asian and European materials, the Siberian narratives have never been systematically described. The existence of similar elements in texts recorded between the Urals and the Pacific never attracted serious attention from researchers and, as far as I know, there have been no plans to create a regional tale type index. This is despite the fact that such indexes (certainly of very different quality) are available for most of the regions of the Old World.

What can be the reason for such a neglect? To answer this question, we must return to the ATU index mentioned at the beginning of this paper.

The tale type index created by Antti Aarne and later modified and expanded by Stith Thompson is the universally recognized cornerstone of folklore studies. For a long time, it was known as AT (Aarne and Thompson 1961) and only became ATU in the twenty-first century (Uther 2004). Thompson's preferences, interests and knowledge had a crucial influence on the further development of the entire discipline. The Folktale (Thompson 1946) is the key source for understanding Thompson's views. In this book, the following assumptions are most clearly expressed.

Firstly, the system of tale types as discrete and clearly recognized units is peculiar for the territory from Morocco and Ireland to India, while in Southeast Asia, Siberia, and sub-Saharan Africa we have but random and late loans. The tale type system described in AT is a product of civilized societies ("Western civilization"). Siberia was practically ignored by Thompson and was mentioned by him only once; the same goes for Central Asia.

Secondly, there are no significant areal differences inside this system; therefore, it can be analyzed as a whole. The folklore of early civilizations of the Old World has been lost, but the fragments that are preserved in written sources let us suggest that it was not very different from what was recorded in Europe after 1800 .

Thirdly, the folklore of the American Indians (which Thompson knew perfectly well and interpreted as an example of cultural phenomena typical of primitive society) is impossible to study together with the folklore of the "Western civilization". The two traditions correspond to different types of society.

Hans-Jörg Uther tried to correct the faults of the AT index and used more data from non-European traditions (Uther 2004 (1): 7-8). However, the main limitations of the AT remained. The list of selected tale types was not expanded and continued to be based on European data. Only very few original sources on Central and East Asia were added. Most of the Siberian folklore was left beyond the scope of the "international" system. In other words, the conceptual pattern generated by Thompson was not replaced with a new one but reproduced once again. 
The creation of a global and not of a Western Eurasian system of recording and classifying of traditional narratives is impossible without keeping in mind the basic purpose of such work. The elaboration of the typology itself is but a technical task. When creating his index of elementary motifs (Thompson 1932-1936), in addition to the tale type index, Thompson tried to draw data from the entire world into a common framework. However, he did it with a declared purpose of excluding any regional specificity and thus any historical problematic of the research. Being a philologist who began his career with the study of English literature, Thompson could not have done otherwise. He knew little about prehistory and had no interest in it. Our purpose is different, namely to use folklore data for the study of the past; in particular, to reveal migrations, cultural contacts and interaction spheres and ultimately sets of narrative episodes and images that existed in different regions and epochs. Keeping this purpose in mind, we need an integration of the world folklore into a unified system that would emphasize regional differences and not typological similarities.

\section{ACKNOWLEDGEMENTS}

Research for this article was supported by the Russian Science Foundation, grant no. 18-18-00361.

\section{REFERENCES}

Aarne, Antti \& Thompson, Stith 1961. The Types of the Folktale. Helsinki: Academia Scientiarum Fennica.

Anderson, Jake 2004. From Alaska to Greenland: A Comparison of the Arctic Small Tool and Thule Traditions. Totem: The University of Western Ontario Journal of Anthropology, Vol. 12, No. 1, pp. 6-15. Available at https://ir.lib.uwo.ca/totem/ vol12/iss1/2/, last accessed on 22 February 2019.

Arsenyev 1995 = Arsen'ev, Vladimir. Iz nauchnogo naslediia V.K. Arsen'eva. [From the Scientific Heritage of V. K. Arsenyev.] Kraevedcheskii biulleten', Vol. 1, pp. 111-131. Available at http://peb.libsakh.ru:3783/reader/bookView. html?params=UmVzb3VyY2UtNjIy/MDAwMDAyNTY4, last accessed on 19 February 2019.

Baulo, Arkadii (ed.) 2005. Synskie Khanty. [The Syn River Khanty.] Novosibirsk: Izd-vo Instituta arkheologii i etnografii SO RAN.

Berezkin, Yuri 2015. Folklore and Mythology Catalogue: Its Lay-Out and Potential for Research. In: Frog \& Karina Lukin (eds.) Between Text and Practice: Mythology, Religion and Research. The Retrospective Methods Network Newsletter 10. A special issue of RMN Newsletter. Helsinki: University of Helsinki, pp. 58-70. 
Available at http://www.academia.edu/14481230, last accessed on 19 February 2019.

Berezkin, Yuri 2019. Athabaskan - Siberian Folklore Links: In Search of Na-Dene Origins. Folklore, Vol. 130, No. 1, pp. 31-47.

Berezkin, Yuri \& Duvakin, Evgeny 2016. The Captive Khan and the Clever Daughterin-Law. Folklore: Electronic Journal of Folklore, Vol. 64, pp. 33-56. http://dx.doi. org/10.7592/FEJF2016.64.khan.

Berezkin, Yuri \& Duvakin, Evgeny n.d. Tematicheskaia klassifikatsiia i raspredelenie fol'klorno-mifologicheskikh motivov po arealam. Analiticheskii katalog. [The Electronic Analytical Catalogue of Folklore-Mythological Motifs: Thematic Classification and Areal Distribution]. Available at http://www.ruthenia.ru/ folklore/berezkin, last accessed on 19 February 2019.

Dumond, Don E. 2005. A Naknek Chronicle: Ten Thousand Years in a Land of Lakes and Rivers and Mountains of Fire. King Salmon, Alaska: U.S. Dept. of the Interior, National Park Service, Katmai National Park \& Preserve.

Golovnev, Andrei 2004. Kochevniki tundry: nentsy i ikh fol'klor. [Nomads of Tundra: The Nenets People and Their Folklore.] Yekaterinburg: UrO RAN.

Kert, Georgi 1961. Obraztsy saamskoi rechi. Materialy po iazyku i fol'kloru saamov Kol'skogo poluostrova (kil'dinskii i iokan'gskii dialekty). [Samples of Sami Talk.] Moscow \& Leningrad: Izd-vo Akademii nauk SSSR.

Khodzher, Anna 2011. Stekliannaia veranda. Taokhama giaygi. [The Glass Verandah.] Khabarovsk: Khabarovskii kraevoi muzei im. N.I. Grodekova.

Koptelov, Afanasi 1950. Skazki narodov Sibiri. [Folktales of Siberian Peoples.] Novosibirsk: Novosibirskoe oblastnoe gosudarstvennoe izdatel'stvo.

Kryukova 2013 = Kriukova, Elena A. Khun's kolbassam zhili: ketskii tekst / Hun and Kolbassam Lived: A Ket Text. In: A. Filchenko (ed.) Annotirovannye fol'klornye $i$ bytovye teksty obsko-eniseiskogo iazykovogo areala / Annotated Folk and Daily Prose Texts in the Languages of Ob-Yenissei Linguistic Area, Vol. 3. Tomsk: Tomsk State Pedagogical University, pp. 202-294.

Kupriyanova 1960 = Kupriianova, Zinaida. Nenetskii fol'klor. Uchebnoe posobie dlia pedagogicheskikh uchilishch. [Nenets Folklore.] Leningrad: Gosudarstvennoe uchebno-pedagogicheskoe Izd-vo ministerstva prosveshcheniia RSFSR.

Kuzakova, Evdokiia 1994. Folklor mansi. [Mansi Folklore.] Moscow: Institut etnologii i antropologii im. N.N. Miklukho-Maklaia RAN.

Lebedeva, Elena \& Khasanova, Marina \& Kialundziuga, Valentina \& Simonov, M. (comps.) 1998. Fol'klor udegeitsev: Nimanku, telungu, ekhe. [Udeghe Folklore.] Novosibirsk: Nauka.

Lehtisalo, Toivo 1947. Juraksamojedische Volksdichtung. Helsinki: Suomalais-Ugrilainen Seura.

Lukina, Nadezhda 1990. Mify, predaniia, skazki khantov i mansi. [Myths, Legends, Tales of the Khanty and Mansi.] Moscow: Nauka.

Lukina, Nadezhda (ed.) 2004. Skazaniia zemli Tomskoi: khrestomatiia. [Tales of the Land of Tomsk: A Reader.] Tomsk: Izdatel'stvo Tomskogo gosudarstvennogo pedagogicheskogo universiteta.

Margaritov, Vasili1888. Ob orochakh Imperatorskoi Gavani. [On the Orochis of Imperatorskaya Gavan'.] Saint Petersburg: Izdanie obshchestva izucheniia Amurskogo kraia v g. Vladivostoke. 
Neniang, Liubov 1997. Khodiachii um naroda: Skazki, legendy, mify, predaniia, epicheskie pesni, poslovitsy, pogovorki, pover'ia, oberegi, narodnye primety, zagadki taimyrskikh nentsev. [People's Shifting Intelligence: Folktales, Legends, Myths, Traditions, Epic Songs, Proverbs, Sayings, Beliefs, Amulets, Omens, Riddles of Taimyr Nenets.] Krasnoyarsk: Fond severnykh literatur "KhEGLEN".

Nikolaeva, Irina 1999. Ostyak Texts in the Obdorsk Dialect. Wiesbaden: Harrassowitz Verlag.

Paasonen, Heikki 1941. Mordwinische Volksdichtung. Gesammelt von H. Paasonen, herausgegeben und übersetzt von Paavo Ravila. III Band. Helsinki: SuomalaisUgrilainen Seura.

Plesovskii, Fedor 1975. Komi narodnye skazki. [Komi Folktales.] Syktyvkar: Komi knizhnoe izdatel'stvo.

Porotova, Tel'mina (ed.) 1980. Skazki narodov sibirskogo severa. [Folk Tales of the Peoples of the Siberian North.] Vol. 3. Tomsk: Izd-vo Tomskogo universiteta.

Pukhnachev, Vasili 1966. Skazki starogo Tyma. [Folktales of Old Tym.] Novosibirsk: Zapadno-Sibirskoe knizhnoe izdatel'stvo.

Rombandeeva, Evdokiia (comp.) 2005. Mify, skazki, predaniia mansi (vogulov). [Myths, Folktales, Legends of Mansi (Vogul).] Moscow \& Novosibirsk: Nauka.

Thompson, Stith 1932-1936. Motif-Index of Folk Literature. Vol. I-VI. Helsinki: Suomalainen Tiedeakatemia.

Thompson, Stith 1946. The Folktale. New York: The Dryden Press. Available at http:// folkmasa.org/yashpeh/The_Folktale.pdf, last accessed on 22 February 2019.

Titov, Elpidifor 1936. Materialy po ustnomu tvorchestvu evenkov Pribaikal'ia. [Materials on the Oral Creative Work of the Cis-Baikal Tungus.] In: G. Vasilevich (comp.) Sbornik materialov po evenkiiskomu (tungusskomu) fol'kloru. Issue 1. Leningrad: Izdatel'stvo instituta narodov Severa, pp. 162-212. Available at https:// yadi.sk/d/q_ivzGyfHwwVr, last accessed on 22 February 2019.

Tsintsius, Vera 1982. Negidal'skii iazyk: Issledovaniia $i$ materialy. [The Neghidal Language: Studies and Materials.] Leningrad: Nauka. Available at http://altaica. ru/LIBRARY/tungus/negidal.pdf, last accessed on 20 February 2019.

Tuchkova, Natalia (comp.) 2004. Mifologiia sel'kupov. [Selkup Mythology.] Tomsk: Izdatel'stvo Tomskogo Universiteta. Available at https://www.academia. edu/31457383/, last accessed on 20 February 2019.

Uther, Hans-Jörg 2004. The Types of International Folktales: A Classification and Bibliography Based on the System of Antti Aarne and Stith Thompson. Vol. 1-3. Helsinki: Suomalainen Tiedeakatemia.

Vasilevich, Glafira 1936. Materialy po fol'kloru sibirskikh evenkov. [Materials on the Folklore of the Siberian Tungus.] In: G. Vasilevich (comp.) Sbornik materialov po evenkiiskomu (tungusskomu) fol'kloru. Issue 1. Leningrad: Izdatel'stvo instituta narodov Severa, pp. 1-136. Available at https://yadi.sk/d/q_ivzGyfHwwVr, last accessed on 20 February 2019.

Vitashevski, Nikolai 1912. K materialam o iakutskikh skazkakh. [To the Materials on Yakut Folktales.] Zhivaia starina, Year 21, Vol. 2-4, pp. 449-466.

Voskoboinikov, Mikhail \& Menovshchikov, Georgi 1951. Skazki narodov Severa. [Folktales of the Peoples of the North.] Moscow \& Leningrad: Gosudarstvennoe Izdatel'stvo Khudozhestvennoi literatury.

Yevsevyev 1964 = Evsev'ev, Makar. Mordovskie narodnye skazki i zagadki. [Mordovian Folktales and Riddles.] Saransk: Mordovskoe knizhnoe izdatel'stvo. 


\title{
WHAT DOES THE STORYTELLER SING? ON TRANSCRIBING THE EPICS OF SOUTH SIBERIAN TURKS
}

\author{
Dmitriy Funk \\ Department of Ethnology \\ Lomonosov Moscow State University, Russia \\ Department of Anthropology and Ethnology \\ National Research Tomsk State University, Russia \\ e-mail:d_funk@iea.ras.ru
}

\begin{abstract}
When and how do we recognize the meaning of epic poetry? Turkic peoples of South Siberia, the Shor and the Khakas, are famous for their recitations and song of classic epic tales, but even indigenous researchers are divided on the meaning of the sung portions. This essay takes seriously these sung portions of epic performances to argue that they constitute meaningful poetic texts in their own right. Examples draw on years of field study in South Siberia, and well as an experiment conducted by the author with the help of the Shor storyteller Vladimir Tannagashev (1932-2007), in which epics were performed a cappella, that is, without throat-singing or musical accompaniment.
\end{abstract}

Keywords: oral epics, the Shors, South Siberia, storytellers, textualisation

The question put forward in the very title of the article, 'What does the storyteller sing?', may seem pointless at first sight. Song can cover anything and everything. In classic examples, a storyteller may offer an epic/heroic legend or a heroic poem, thus telling us about the great deeds of famous men and women. But is there more? This question has turned out to be one of the most complicated in the history of epic studies relating to peoples with whom I have worked for many years - the Altai-Sayan Turks.

The problems of textualisation of oral epics as well as of the role of performance's musical component have long been discussed within the field of epic studies globally (see, for example, Gatsak \& Petrosian 1971; Foley 1995; Honko 1996: 1-17, 2000; Reichl 2000a, and many others). With regard to heroic epics of the Turkic peoples, many issues have been successfully analysed, such as the publication of epics written down by dictation, lack of the audience reaction to performance, and just as often, the non-authentic nature of recordings made 
without the actual atmosphere characteristic of live performances. Of all these issues, perhaps musical accompaniment has presented the greatest debate (Hatto 2000: 129-160; Reichl 2000b: 103-127, and many others).

I myself started listening to and recording Shor heroic epics ${ }^{1}$ in 1983 , but it was not until 2011 that I dared to transcribe one of my audio/video recordings for the first time. This resulted in the publication of one epic story titled 'Qara-Qan' (SHGE 2012: 126-182). The performance lasted for just over half an hour, and yet it took me three days to produce the first draft transcription. I then spent a few more months trying to understand unclear moments in the audio recording and to get it translated into Russian the way I myself more or less understood it. Here I should stress that the epic was spoken rather than performed in the traditional manner characteristic of Shor qaichi as well as Khakass khaidji storytellers, that is, by throat-singing (qai/khai) along with playing a special musical instrument and with the conventional subsequent retelling of the parts being sung. Despite the fact that at least two attempts have been made in post-Soviet Russian folklore studies to publish Shor epics as they were once traditionally performed (see SHGS 1998: 49-262 (musical notation and text), 263-321 (translation); FSH 2010: 71-145 (musical notation and text), 146-179 (translation)), I suggest that this task remains not just complicated but also - given the lack of understanding of the gist and meaning of the epics' sung parts - rather unproductive.

Below I turn to discussing what and how the storyteller sings when performing such epics and what is at stake when we render them in written form.

\section{ON THE HISTORY OF PUBLISHING HEROIC EPICS}

Scholars have long expressed interest in the epic tales of the Khakas ${ }^{2}$ and Shors, yet most of them have overlooked a crucial detail: in their performances, storytellers almost always create two separate texts instead of one, each different in the way they were presented/performed.

Nadezhda Dyrenkova (1899-1941) first made this point in relation to Shor heroic epics. In 1940, she wrote: 'Heroic poems ... performed by the Shors constitute semi-poetic, semi-prose works. Usually, the poetic text of a poem is interrupted by quite long prose passages' (SHF 1940: XXXVII). She then went on: '... the storyteller, having sung one or several couplets, proceeded to retell what had been sung...' (ibid.: XXXVIII).

Perhaps it is not surprising that Dyrenkova did not pursue her point further, as it was merely not worth trying to handwrite the epic during performance thereof without special audio-recording equipment. What Dyrenkova did manage 
to write down by dictation was seen by her as 'prose' and for that very reason in the well-known volume 'Shorskiy Folklor' (Shor Folklore) - when publishing heroic poems - only a few starting and concluding lines which were clearly and rhythmically organised, divided into verses, would be given by the researcher; the main text of the epic was published as prose ${ }^{3}$ where in fact it could quite often (and at least partially) be represented as a poem.

Aleksandr Smerdov (1910-1986), a poet from the city of Novosibirsk, attempted to move away from such a way of presenting texts and to basically return to what Wilhelm Radloff had proposed a century ago with regard to Siberian Turk folklore (Radloff 1866). ${ }^{4}$ Three out of the six Shor texts that he published in Russian were translated in a manner maximally close to that of a poem. Those were the epics collected from Nikolay Napazakov (1870-1942) 'Ay-Tolay' (Ay-Tolay 1948: 31-55), 'Altïn-Qilišs' (ibid.: 56-95) and 'Altïn-Som' (ibid.: 96-122). However, in this case translation came as an initiative on the part of the poet himself and - as far as I can judge, based on the handwritten original of the epic 'Altïn-Som'6 - was not directly linked to the text found in dictation.

In the late 1940s to the early 1950s, Olga Blagoveshchenskaya became the first researcher who, with the help of the Shor storyteller Stepan Torbokov (1900-1980), managed to produce a translation totally consistent with the Shor handwritten original, that is, with the division of the text into verses. Two of the six epics that she prepared for publication, 'Qaan-Čayzan and Piy-Čayzan' (3194 poetic lines) and 'Kök-Aday' (1845 poetic lines), were in full accordance with the poetic self-made recordings of the epic and its subscript translation (Funk 2010: 120-137; SHGE 2011).

It was only in the very late 1960s that first tape-recordings of the Shor heroic epics in their authentic form were made, in which the epics were performed by throat-singing and accompanied by a musical instrument and retelling of the parts sung. In this same way folklore researcher Andrey Chudoyakov (1928$1994)^{7}$ recorded several epics of the Shor qaichi storytellers. From the 1970s to the 1990 s, there already appeared many more researchers in folklore, ethnography, and musicology, who had such recordings at their disposal.

\section{THE FIRST EXPERIENCE OF RECORDING AND TRANSCRIBING EPICS' SUNG PASSAGES}

In the late 1980s, ethnomusicologist Anatoliy Stoyanov beautifully characterised the manner in which Khakas heroic epics were performed. A central example came in a small passage on 'khai storytelling' (8 verses) and in the 'declaimed 
retelling of what has been sung' (9 verses) taken from the epic 'The Nine-YearOld Alïp-Khan-Khïs', performed by S.P. Kadyshev (Stoianov 1988: 588-590). However, the distinctive features of the Khakas epics' performance identified/ described by the researcher were not used when other Khakas folklore samples were released.

Almost in parallel with this, in 1984 and 1987, musicologist Irina Travina (1927-2005) undertook field expeditions among the Shors. She managed to tape-record two epic texts: one from Mikhail Kauchakov (1934-2014) - a great story of 'Altïn-Ergek', consisting of over 230 musical and prose passages, and the other (which was an instrumental version with no lyrics) from Afanasiy Ryzhkin (1924-2003) - 'Aq-Salgïn'. Travina presented some of the collected materials and results of a musicological analysis thereof in her monograph abundantly illustrated with musical notations (Travina 1995). Heroic epics occupied a considerable part of this publication. Travina transcribed four passages from the story 'Altïn-Ergek', which she regarded as the keynote, namely the ones relating to 1) Altïn-Ergek, 2) the hero being on his way, 3) the fighting hero, and 4) sorrow (Travina 1995: 53-63), as well as provided the musical notation of a long passage from the story of 'Aq-Salgïn' (ibid.: 64-69). As I have already noted before (Funk 2005: 238), it was in this way that such transcriptions appeared in Shor epic studies for the first time.

Soon after Travina's book came out (practically unnoticed by folklorists), for the first time a Shor epic was released, being presented in a way that was meant to be as authentic as possible in terms of the epic's actual performance in the qai manner, that is, through singing and "retelling". This simple yet bright idea of publishing the story of 'Qan Pergen' (written down by Chudoyakov in 1967 from the qai storyteller Kydyiakov (1908-1970)) belonged to Viktor Gatsak (1933-2014), the editor of the publication, who had proposed to publish the text exactly the same way it was performed by storytellers, alternating the signing and telling of the epic's parts and adhering to the principle of indissolubility of the text (SHGS 1998: 31). The publication turned out to be indeed unique in its kind. The prose (rhythmic) part of each of the 102 epic parts was transcribed and translated into Russian to the fullest extent possible.

I will not go into detail regarding the division of the so-called prose part of the story of 'Qan Pergen' (as well as of the second text published in that book 'Altïn Sïrïq', performed by the same storyteller but in the narrative manner, without singing) into verse. Such an approach has the right to exist, although obviously a significant part of the 'poetic lines' here was produced by the publisher rather than by the storyteller. When the text is divided into 'verse' this way, eventually - and in a manner that is absolutely natural when it comes to the narrative style of epic performance, with the storyteller often shifting 
to simply tell the story regardless of his poetic talent - these become devoid of a distinct rhyme.

I shall now turn to the form in which Gatsak's work presented the sung parts of the epic story. And it is from this analysis that we can clearly see that the initial idea behind the publication proves to be at least not fully implemented. To illustrate this point, I draw attention to two passages from the story of 'Qan Pergen'.

\section{Passage 23}

Below is the transcription which accompanies the musical notation:

Hay-dey yu

Qonoyo perdi

Qayran Qaan Pergen adan körüp

Qayran turdï

Šaq po čerde

Qaraqü amdï per

Amdï he perdi

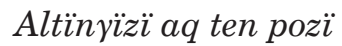

Aq tuvan či ̈̈ÿ̈rap kelip

Čaykoq turyan am polyan či

Arazïmperey.

(SHGS 1998: 99-100)

Translation:

The glorious Kan Pergen can see that 'here below and up to the khan-sky, there is a white haze spreading' (SHGS 1998: 274).

In this case, there is no need to comment on the accuracy of the 'translation'; however, it is worth noting that in the Shor original, not the slightest reference is made to the khan-sky - an image that appears only in the Russian text.

\section{Passage 26}

Qayran pir poldï, poldï dey dey

Šaq po pir čerge dey dey

Qadïyoq agaš dei dey

Qaqšilaš qaldï dei poldï dei dey

(...) qayran qara pir dei dey

Tügedeš qaldï dey do

Uyada qušum dey poldï dey do

Uyaday čaštoq dey dey

Adačaq čašqa dei do 
Palačaq taštap dei do

Qazïrlar qaptïrdï poldï dey do

Paladay častoq de $i$ do

Amdï qarïyanï dey dey.

(SHGS 1998: 105-108)

Translation:

The description of a battle. The heroes are fighting 'as if they were two strong trees hitting against one another' with such force that 'the birds that had their nests in these trees start to lose them' (SHGS 1998: 275).

In both cases, the declaimed part of the epic (i.e., the retelling of what has been sung), both in the original and in translation, was presented in the book as verse: the 'retelling' of the 23rd passage in 10 lines, and that of the 26th passage in 103.

A sequence of these examples could be as long as the epic itself, but even from the excerpts provided it becomes clear that in this case the 'reverse' principle of presenting the original to the reader was realised throughout the 'translation'. All the epic parts to be sung in the Shor original consist of partially transcribed words or combinations of words that are far from being poetic; the Russian translation presents these as a very approximate retelling in the form of prose (and this is indeed a retelling, not a translation). This said, all the prose (or, at best, prosimetric) parts of the epic are given as a text divided by its editor into 'verse' lines.

I have already touched upon the question of the possibilities and legitimacy of presenting a text performed in a narrative manner in the form of a verse as well as upon issues relating to such a way of performing. Here, I would like to look into why the parts which were to be sung and were thus organised as a poem turned out to be hardly transcribed or translated? Perhaps this was the case due to the unintelligibility of the sung lines for the researcher?

In his foreword to the volume of the Shor epics, Chudoyakov wrote:

There are 102 segments of different length and structure in this work which are sung and accompanied by qai-qomus and 92 segments told as verses. Some of the passages are not performed in a 'narrative' manner. ${ }^{8}$ (SHGS 1998: 29)

He adds:

Some of the parts to be sung cannot be transcribed as everything should be in line with the rhythm formation and the melody, hence the words are pronounced in a truncated and distorted manner and often do not fit together, and also abundant are the monosyllabic words like dey, di, do, pir, etc. (SHGS 1998: 30) 
Apart from 53 musical notations of the epic parts to be sung, the volume prepared by Chudoyakov includes 'subtexts for the musical notations (where it was possible to transcribe)'. In the Russian translation though, when dealing with the 'subtexts' 'with their truncated words, a maximally simple way of transferring meaning has been adopted, with inclusion of some quoted sentences and words which lend themselves to transcription and translation' (SHGS 1998: 31-32, emphasis added).

It is clear that all of the102 segments of the epic that were performed by throat-singing and accompanied by qai-qomus were so difficult for the editor and translator to understand (despite the fact that the Shor language was his mother tongue!) that he could only partly fulfil the task of transcription. Broadly speaking, it is not surprising, considering that, as Chudoyakov himself rightly noted, 'everything should be in line with the rhythm formation and the melody' (SHGS 1998: 30). However, it seems to me, one word was disregarded here, and that is 'everything'. In other words, a quite obvious question remained unanswered, namely, what exactly was in line with the rhythm formation and the melody'?

In their work on sung passages, researchers of Shor epics made somewhat greater progress when preparing the next volume of the series, titled 'Folklore Monuments of the Peoples of Siberia and the Far East' (FSH 2010). Lyubov Arbachakova, the volume's editor and translator, managed to provide not just a retelling, as Chudoyakov did, but a translation of the epics' sung parts, 'despite the seemingly fragmented nature and incompleteness of the musical piece' (FSH 2010: 19). Nevertheless, none of the sung fragments (passages) here were verses either. Rather, these were 1-2-3 words that were heard and made sense of in the course of transcribing each line, accompanied by some words for 'warming up', as follows:

\section{Passage 17}

Anaך čügürüp... qayrin... Körzer üšter qulaqtïy... Attar čügürüp... toguš... Körgey ołner qaraqtïg... Altïn...di

Oqča pozun keze...

Köstedi...

Učuq kelip turganoq... Čooqtažïp turdïy... (FSH 2010: 115)
Then riding his horse... along the road... He sees with three ears... Horses running... met... They see with ten eyes... Golden... di An arrow to pierce him... Aiming at a target... It started flying... They started talking... (FSH 2010: 165) 
Can it really be that the sung parts of the epic are just 'truncated' and 'distorted' words that 'do not fit together'? Or can it be that the words the storyteller sings are there only for the music to be accompanied by a semi-meaningful text? How then should we deal with the fact that 'a part of the passages is not accompanied by their "narrative version"? It seems the case here is that these sung parts did have a meaning and that this meaning was clear to listeners, at least to those who listened to this storyteller regularly.

\section{EMIC EXPLANATIONS OF WHAT (AND WHY) IS BEING SUNG AND RECITED}

When considering the specific features of epics performed by the Shor (and Khakas) qaichi/khaidji, we should also bear in mind the purely practical need for the sung parts to be retold. The thing is that there were only a few storytellers capable of singing clearly and intelligibly. The situation where the audience either does not understand the sung text at all or understands only some scraps of phrases and the general mood can be regarded as a norm. Sometimes this manner of performance would generate fantastic explanations.

I encountered one interesting reason for alternating a sung part with its retelling in the work of Canadian researcher Kira van Deusen. According to her reference to a contemporary Khakas singer seeking to master the art of Khaidji-storytelling, 'this allows to clarify the part sung in the khai manner and, maybe, in the language of spirits difficult for ordinary listeners to make sense of' (Van Deusen 2000: 231).

The Shor storytellers - and I had a chance to converse with at least a dozen of those who saw themselves as storytellers - have never told me of anything like this. Knowing that those who listened to the epics - and I have witnessed that myself - would listen with full attention to both the singing and the retelling of the sung parts and could simultaneously laugh and cry when the sung parts were being performed, the only reasonable thing to assume was that a Shor qaichi-storyteller singing in the qai manner sings not 'in the language of spirits' but rather in the Shor language. As a rule, the storyteller does not receive any information from without, from spirits, but he himself seeks to obtain it, he himself is present 'in the story' and sings and tells the listeners about what he sees (for more see Funk 2005: 331-352).

Here is an extract from my conversation with the Shor storyteller Tannagashev (T.), in which we discussed the need to have a prose retelling: 
T.: When some storytellers sing, it is not quite clear what they sing. But no matter how many times I sing, I am told that it is amazing how easy it is for them to understand me word for word. Mikhail's performance [Mikhail Kirillovich Kauchakov - D.F.] was difficult to understand. And some [sing the words] as if in passing, it seems.

F.: Why do you need to first sing a piece and then retell it? The two passages do not always coincide.

T.: When you sing, maybe, it is more for embellishing the words - you say one word and up another word comes. But in fact it is all the same. Without embellishing, the singing won't do, it will be distorted. It won't be as beautiful and tactful [rhythmical - D.F.], and as 'direct' as a verse, and smooth enough.

F.: There are storytellers who simply sing fairy tales...

T.: It is also possible. But then again all the people need to understand. Otherwise, you first sing and then retell - that was the case since the beginning of time. And what you sing needs to be clear. I used to not understand everything Pavel Petrovich [Tokmagashev - D.F.] sang the way he sang. Opim-apshiy [the Khakas qaichi Opim Podachakov - D.F.] ... his singing was completely unintelligible. He used to have only a melody. [He had] no teeth at all, his lip would even lean to the side. You couldn't make sense of any of his words. But [when] he was speaking - he spoke clearly. ${ }^{9}$

\section{WHAT DOES THE QAICHI SING?}

In an attempt to answer the question raised above, I defer to the epics performed by Pavel Kydyiakov, who died almost half a century ago. I then turn to my own field materials gathered with the help of the qaichi Vladimir Tannagashev (1932-2007), who represented the same regional school of storytelling as Kydyiakov (for more about Tannagashev see: SHGE 2010: 139-159; Funk 2014: 7-36).

In the course of regular work with Tannagashev and thanks to our joint efforts, I managed to conduct several experiments on the re-recording of nearly a dozen epic stories performed in different ways. These were throat-singing performances with 'retelling' of the parts sung, narration in the prosimetric form, and self-recordings. However, it took me a long time before I was able to clearly formulate the task for the storyteller with regard to understanding of what is being sung. I repeatedly asked him to retell the sung parts 'word for word' but he would only 'repeat' those in the prosimetric form or as prose, 
insisting that this was exactly what he was singing. This went on and on, up until the moment I managed to put into words - for myself - the essence of the problem, or rather of the question: What is it exactly that does not allow me to hear (and understand) the poetics/language of the epic's sung parts? Just to remind you: the storyteller himself claimed that these were in verse.

And I have found the answer: firstly, it was about the music muffling words that were being sung (something that researchers had paid attention to before; see Reichl 2000b: 103-127), and secondly, it was about the very manner of performing the epics, by throat-singing, where many words were not sung in full, or were sung somehow differently in accordance with the length of a melodic line and the specific features of sound production.

The only thing left to be done was to ask the storyteller to perform the sung parts without playing the musical instrument (qai-qomus) and without throatsigning, that is, in a normal voice. Surprisingly, he agreed to do so straightaway, saying: 'This is also possible'.

The issue of understanding the sung parts of Shor epics, which had been unresolved for one and a half centuries, turned out to be resolved in a minute when the right question was put forward.

In the end, I had a few variants of the performance of the epic 'Forty-Breasted Qïday-Arïg' at my disposal and, more specifically, of one episode in which QïdayArïg appears and the first fight between her and the heroine, Altïn-Čüstük, takes place. The storyteller himself recorded this episode in late October to early November 2003 (the full recording of the text) and then approximately in a month it reappeared through my full audio and partly video recording of this same epic's performance in the prosimetric form (the recording dated 10.12.2003) and also in the recordings of the given episode performed by 'ordinary singing' a cappella without qai and music (the recording dated 23.10.2006).

Several versions of this bright epic, along with a detailed textological analysis, are to be published in one of the next volumes of the 'Shor Heroic Epic' series. Here I would only like to share some general observations which are important for the understanding of the structure and meaning of the Shor epic's sung part.

The rhythmic formula of the pieces sung a cappella is quite stable and in most cases it is represented by verse lines with a distinct division of each of these into two parts (two hemistichs) or sometimes into three parts of 4 to 5 syllables each.

The first piece that Tannagashev sang to me from the epic about the FortyBreasted Qïday-Arïg without qai-qomus and throat-singing consisted of 8 lines/ verses where verses 1-4 and 8 were two hemistichs of 4 to 5 syllables each, and verses 5-7 were much longer (of 16,15 , and 13 syllables respectively) due to the introduction of a third significant part thereto, which allows to complete the idea expressed at the beginning of this verse: 
I.

\begin{tabular}{|c|c|c|}
\hline$O-d u r-c ̌ u-\gamma a y-(\ddot{i n})$ & $t u s ̌-t a(a)-r \ddot{n} n-d a$ & \\
\hline čer-ler üs-tü & $n i$-gi-liš-če $(e)$ & \\
\hline če-gen $a r-\gamma a-z \ddot{i}$ & tar-ta-lǐš-ča-(no) & \\
\hline$q a y-r a n-(a n) e-n e(e) n$ & $a q-(t a r) b e r-y a n$ & \\
\hline$q a y$-ran-oq a-ba(a) & sen-(ner)-oq ayt-qü(ï)n & (am na-rï) sös-čaq \\
\hline$a q-(t a r) \check{c} a-r \ddot{q} q-q a$ & 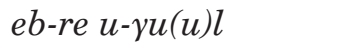 & (qay-ran) par-yan-(no) \\
\hline pis-tī-oq čer-ge & öl-bes-par-ba(a)s & 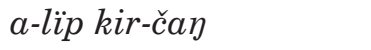 \\
\hline 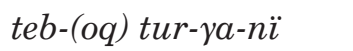 & $A l$-tïn-Č̈̈us-tü $(\ddot{u}) k$. & \\
\hline
\end{tabular}

I draw particular attention to the semantic completeness and (with minor exceptions) the grammatical form of each of the verses and sentences. Indeed, there are 'warm-up' words in the sung part (presented both as excessively used grammatical forms -tar, -ner, -oq and others, and as 'warm-up' words per se am, amnar, no, and others), and often used are the unusual for everyday speech lengths of the vowels or, conversely, their truncated variants, and so sometimes some words do get really distorted (the fact that Chudoyakov had pointed to). Nevertheless, what the storyteller sings each time is no less than a verse filled with meaning.

Each verse that I split into two or three parts could be written down otherwise, where each part would be presented as a standalone verse itself. Below, I provide an example of a passage sung a cappella, divided into verses of 4 to 5 syllables each (with no additional breakdown into syllables as shown above).

\begin{tabular}{|l|l|}
\hline Text sung a capella & Translation \\
\hline odurčuyayïn & sitting they were \\
\hline tuštarïnda & when \\
\hline čer ler üstü & the earth's surface \\
\hline nigilišče & started shaking \\
\hline čegen aryazï & the foundation of the universe \\
\hline tartalïšč no & widened \\
\hline qayran an enen & dear mother \\
\hline aq tar beryan & $\ldots \ldots . . . .$. \\
\hline qayran oq aba & dear father \\
\hline sen ner oq aytqün & said by you \\
\hline am narï sösčaq & the words \\
\hline aq tar čarïqqa & across the whole wide world \\
\hline ebre uyul & are heard \\
\hline qayran paryan no & (dear) have become \\
\hline pistin oq čerge & [because of this] our land \\
\hline ölbes-parbas & the immortal \\
\hline
\end{tabular}




\begin{tabular}{|l|l|}
\hline alïp kirčan & hero enters \\
\hline tep oq turyanï & so said \\
\hline Altïn-Č̈üstük & Altïn-Čüstük \\
\hline
\end{tabular}

This sung verse's basic structure can also be clearly seen in other passages sung a cappella (equating to 117 verses if split into lines of 4 to 5 syllables each), of which I shall give here only one more example:

\section{II.}

Qal-qa-lïg dey am köz-nük-ti qay-ra šap sal a-naך kör-ze-le(e)r:

at-tar aš-pas ar-ya-lï zïn-ya to-yus ay qa-ra(a)t ke-lip tüš-tü-ler to-yus ay qar-at am-nar üs-tün-ge(e) te-bir-e sal- čaq sa-lïl par-tür te-bir sal-dï(i) $\eta$ am üs-tün-de qü-rïq em-ček-tig Qï-day-A-rï(i)

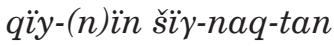
ča-d̈̈p sal-tïr.

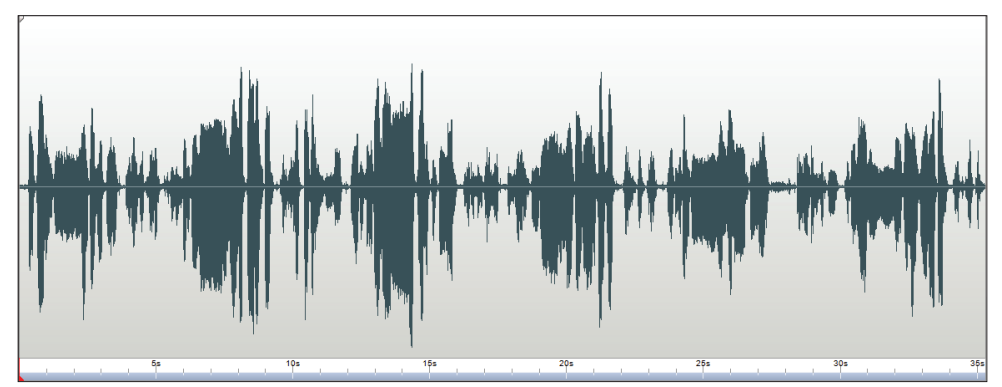

Figure 1. The sound waves (shown in the WavePad Master's Edition v.6.23) of excerpt II given above. Screenshot. 
It is not difficult to see, firstly, that absolutely all the sung verses are indeed a poetic text and, secondly, that it turns out to be quite a meaningful and therefore transcribable undertaking.

It can be stated with confidence that the storyteller was right saying there was practically no difference between the epic sung and the epic retold. This can be clearly seen from excerpt II sung a cappella (and presented in the recording without 'warm-up' words) and the corresponding semantic passage from the self-recording ${ }^{10}$ of this epic made by Tannagashev ${ }^{11}$ :

Self-recording (2003)

At ašpas aryalïg sïnya

On a mountain ridge impassable for a horse, Toyus para ${ }^{12}$ ay qarattar kel tüštüler.

Descended nine sparkling black horses.

Toyus para ay qarattardïn üstünge

On the nine sparkling black horses

Tebir sal saldïr saltïr,

There is an iron platform, it turns out,

Tebir sald̈̈y üstünde

On the iron platform

Qürïq emčektig qüs palazï čat saltïr.

There is a forty-breasted girl lying.

Qïs palazï qüyïn čatqan ozïba qüyyï kel salča ...

The girl, lying on her side, leaning on her elbow, is screaming ...

\begin{abstract}
Singing a cappella (2006)
Attar ašpas aryalïg sïnya

On a mountain ridge impassable for horses,

Toyus ay qarat kelip tüštüler
\end{abstract}

Descended nine sparkling black horses.

Toyus ay qarat(tüy) üstünge

On the nine sparkling black horses

Tebir salčaq salïp partïr

There is a small iron platform, it turns out,

Tebir saldïy üstünde

On the iron platform

Qürïq emčektig Qüday-Arïg

There is forty-breasted Qiday-Arïg

Qïÿ̈n šĭy(a)naqtan čadïp saltïr

Leaning on her elbow is she lying, it turns out.

And yet, the main question of what exactly the storyteller sings when performing the epics, by throat-singing and accompanied by his two-stringed musical instrument, remains open. To try and answer it, I recorded the same passage describing the first meeting and fight between Altïn-Čüstük and the FortyBreasted Qiiday-Arïg performed in the qai manner by the same storyteller Vladimir Tannagashev. The video recording of approximately 11 minutes in total had been produced on 22 October 2006, one day before the storyteller 
performed this passage a cappella for me. The transcription of the entire recording (as well as of the whole text performed a cappella) will be published later on; here though I find it important to demonstrate the principal stability of the performed text, regardless of the performance style, be it prosimetric, a cappella or qai singing.

Let us start from the very beginning (see the first passage sung a cappella above), but this time we shall look at a text performed in the qai manner (the left column) and compare it with the lines sung a cappella (the right column):

\begin{tabular}{|l|l|}
\hline Odur oy ep čïyïn & Odurčuyayïn \\
tep oq tüštarïn dey & tuštarïnda \\
čerler pir üštü & čerler üstü \\
qïybražïp čaran oq & nigilišče \\
čegen pir tübü & čegen aryazï \\
qïy(...)iš turyan oq dei-döy & tartališča no \\
& qayran an enen \\
& aq tar beryan \\
qayran abïy & qayran oq aba \\
sen ner aytqan & sen ner oq aytkïn \\
qayran oq sösček & am narï sösčaq \\
aq tar čarïqqï & aq tar čarïqqa \\
ebirey uyul & ebre uyul \\
qayran paryan no & qayran paryan no \\
pistin oq čerge & pistin oq čerge \\
ölbes-parbas & ölbes-parbas \\
alïp oq kirče & alïp kirčan \\
tep oq turyanï & tep oq turyanï \\
am nar Altïn oq & Altïn-Čüstük \\
qayran oq Čüstük & \\
qïs tar palazï & \\
adazï paroy & \\
\hline
\end{tabular}

When singing the epic in the qai manner, the storyteller obviously takes as a measure the length of a musical phrase to which he adapts a performed verse and hence the use of 'warm-up' words. Among them there are also plural formatives (-ner, -nar, -tar) and words or particles which have an independent meaning in the language (of the type of oq - 'zhe'13, pir - 'one', qayran - 'affective' (both the feminine and masculine forms)) and 'warm-up' words per se which do not bear any meaning, such as dey, dei-döy, no or oy/ey, which sometimes can substantially change the phonetic form of the main word as is the case with the word pariy, which, when sung in the qai manner, turned into paroy, or ebire, which was sung as ebirey. 
It should be noted that in the course of singing there is also the possibility of varying suffixes and root sounds (both vowels and consonants; for example, $\ddot{u}$ štü sung instead of üstü when performed in the qai manner). The word sös 'word', in different variants of singing, took on the diminutive form with the affixes - čaq and -ček (sösčaq and sösček; in the first case with the violation of the vowel harmony rule). In affixes there can be noted a steady and equal alternation of $\ddot{i}$ and a: aytqan, the literary norm aytqün; čar ̈̈qqa, the literary norm čarïqqï. In the case with the verb form kirča, 'enters', third-person singular, in both variants of singing I did not come across the normative form at all: kirče, qai and kirčay, a cappella.

As can be seen from the transcription below, even the name of a character can not only be accompanied by 'warm-up' words but also be broken by them as was the case with the name Altïn-Č̈ustük. In the qai singing, this name was sung in 4 verse lines:

\begin{tabular}{|l|l|}
\hline am nar Altïn oq & now nar (plural) Altïn zhe \\
\hline qayran oq Čüstük & dear zhe Čüstük \\
\hline qïs tar palazï & girl tar (plural) child \\
\hline adazï baroy & well-known \\
\hline
\end{tabular}

As the experience of transcribing the epics' sung parts shows, there are grounds to start preparing Shor epic stories performed in the traditional qai manner for publication exactly the way they are sung. This way, both in the recording and in translation, the sung text is indeed perceived as actual verse, and not just as a hint, an accident, or suggestive filler.

\section{ACKNOWLEDGEMENTS}

The paper was written as part of the project "Language and ethno-cultural variability of Southern Siberia in synchrony and diachrony: Language and culture interaction" (RF government grant No. 14.Y26.31.0014).

\section{NOTES}

1 Shors (approximately 13,000 people as of 2010) are a Turkic ethnic group that is officially recognized in Russia as a small-numbered indigenous people of the North, residing in the south of Kemerovo region (see more in Kimeev et al. 2006: 236-324).

2 Khakas (approximately 73,000 people as of 2010) are a Turkic ethnic people residing in the south of Siberia. Their main territory of residence is the Republic of Khakassia (Krasnoyarsk region, Russia) (see more in Butanaev 2006: 533-630). 
${ }^{3}$ In 1940, in parallel with the book by Dyrenkova, Shor linguist Georgiy Babushkin (1907-1969) published a number of Shor epics in prose (Babushkin 1940).

4 Four of the eight Shor texts published by Radloff in their contemporary written form and their translation into Russian can be found in SHGE 2013.

5 Hereinafter all storytellers' lifespans are based on my field materials (see Funk 2005: 379-387).

6 As I understand it, this is the only fragmentarily preserved Shor original (kept at the Museum-Reserve 'Tomskaya Pisanitsa' in the city of Kemerovo) of those texts that constituted the basis for Smerdov's poetic translations.

7 It is rather difficult to conclude how many texts performed this way were written down by Andrey Chudoyakov, according to the list of materials left behind after the researcher's death in 1994 (see Trudy 1998: 146). Judging from the length of the surviving recordings (which is also indicated in the list), except for the text of the story 'Qan-Pergen' recorded by Pavel Kydyiakov, this could also be the story of 'Qara-Qan', recorded by P.P. Tokmagashev (the list provides an inaccurate name-P.P. Tokmashev).

${ }^{8}$ Qai-qomus is a two-stringed plucked musical instrument of the lute type. It was usually made of willow or cedar.

9 From a conversation with the storyteller on 24 July 2002, city of Myski, Kemerovo region.

${ }^{10}$ A scanned copy of the manuscript, transcription, and standardised variant of this selfrecording are available at http://corpora.iea.ras.ru/corpora/. For more on the structure of this corpus of texts on the languages of the peoples of Siberia and on the order of texts therein, see Funk 2013: 193-204.

${ }^{11}$ In both cases, I standardised the orthography in accordance with the contemporary norms of the Shor literary language. Translations from the Shor language are mine.

${ }^{12}$ I specifically discussed the translation of this word with the storyteller. Evidently, it was borrowed from Russian, and in this verse the wording toyus para should have been translated as 'nine pairs'; however, the storyteller himself rejected this categorically, claiming that he used the word para 'for embellishment'.

13 The particle ' $z$ he' is used in the Russian language to amplify the meaning of a preceding word or phrase.

\section{REFERENCES}

Ay-Tolay 1948 = Ai-Tolai: Narodnye geroicheskie poemy i skazki Gornoi Shorii. [Ay-Tolay: Folk Heroic Poems and Fairy Tales of Gornaya Shoriya.] Novosibirsk: Novosibgiz.

Babushkin, Georgii 1940. Shor nybaktary. G.F. Babushkin paskan. [Shor Tales. Recorded by G.F. Babushkin.] Novosibirsk: Novosibirsk: Novosibirskii oblastnoi gosudarstvennyi izdatel'stvo.

Butanaev, Viktor 2006. Khakasy. In: D. Funk \& N. Tomilov (eds.) Tiurkskie narody Sibiri. [The Turkic Peoples of Siberia.] Moscow: Nauka, pp. 533-630. 
Foley, John Miles 1995. The Singer of Tales in Performance. Bloomington: IN: Indiana University Press.

FSH 2010 = Fol'klor shortsev: v zapisiakh 1911, 1925-1930, 1959-1960, 1974, 1990-2007 godov. [The Shor Folklore: In the Records of 1911, 1925-1930, 1959-1960, 1974, 1990-2007.] Novosibirsk: Nauka.

Funk, Dmitri 2005. Miry shamanov i skazitelei (kompleksnoe issledovanie teleutskikh $i$ shorskikh materialov). [Worlds of Shamans and Storytellers (a Comprehensive Study of Materials Collected on the Shors and Teleuts.] Moscow: Nauka.

Funk, Dmitri 2010. Novyi arkhivnyi istochnik dlia izucheniia kul'tury shortsev serediny $X X$ veka. [A New Archival Source for Research into the Shor Culture of the Middle of the Twentieth Century.] Etnograficheskoe obozrenie, No. 2, pp. 120-137. Available at http://journal.iea.ras.ru/archive/2010s/2010/2.htm, last accessed on 14 March 2019.

Funk, Dmitri 2013. On the Principles of a Digital Text Corpus: New Opportunities in Working on Heroic Epics of the Shors. Oral Tradition, Vol. 28, No. 2, pp. 193-204. http://dx.doi.org/10.1353/ort.2013.0033.

Funk, Dmitri 2014. The Present State of the Epic Tradition among the Shor (Specific Material and General-Theoretical Problems). Anthropology \& Archaeology of Eurasia, Vol. 52, No. 4, pp. 7-36. https://doi.org/10.2753/AAE1061-1959520401.

Gatsak, Viktor \& Petrosian, Arfo (eds.) 1971. Tekstologicheskoe izuchenie eposa. [A Textological Study of Epics.] Moscow: Nauka.

Hatto, Arthur T. 2000. Textology and Epic Texts from Siberia and Beyond. In: L. Honko (ed.) Textualization of Oral Epics. Berlin \& New York: Mouton de Gruyter, pp. 129-160.

Honko, Lauri 1996. Epics along the Silk Roads: Mental Text, Performance, and Written Codification. Oral Tradition, Vol. 11, No. 1, pp. 1-17. Available at http:// journal.oraltradition.org/files/articles/11i/5_introduction_11_1.pdf, last accessed on 14 March 2019.

Honko, Lauri (ed.) 2000. Textualization of Oral Epics. Berlin \& New York: Mouton de Gruyter.

Kimeev, Valeri 2006. Shortsy. In: D. Funk \& N. Tomilov (eds.) Tiurkskie narody Sibiri. [The Turkic Peoples of Siberia.] Moscow: Nauka, pp. 236-324.

Radloff, Vasili 1866. Obraztsy narodnoi literatury tiurkskikh plemen, zhivushchikh v Iuzhnoi Sibiri i Dzungarskoi stepi, sobrany V.V. Radlovym. [Samples of Folk Literature of Turkic Tribes Living in South Siberia and the Dzungar Steppe, Collected by V.V. Radloff.] Ch.1: Podnarechiia Altaia: altaitsev, teleutov, chernovykh i lebedinskikh tatar, shortsev i saiantsev. [Part 1: Sub-dialects of Altai: The Altaians, Teleuts, Black and Lebedinsky Tatars, Shors, and Sayanians.] St. Petersburg: Tip. Akad. Nauk.

Reichl, Karl (ed.) 2000a. The Oral Epic: Performance and Music. Berlin: VWB.

Reichl, Karl 2000b. Silencing the Voice of the Singer: Problems and Strategies in the Editing of Turkic Oral Epics. In: L. Honko (ed.) Textualization of Oral Epics. Berlin \& New York: Mouton de Gruyter, pp. 103-127.

SHF 1940 = Shorskii fol'klor: Zapisi, perevod, vstupitel'naia stat'ia $i$ primechaniia N.P. Dyrenkovoi. [Shor Folklore. Introductory article, folklore texts, and notes prepared by N.P. Dyrenkova; translated by N.P. Dyrenkova.] Editor-in-chief I. Meshchaninov. Moscow \& Leningrad: Izdanie AN SSSR. 
SHGE 2010 = Shorskii geroicheskii epos. Tom 1. Sost., podgot. $k$ izdaniiu, vstupit. st., per. na rus. iaz., primech. i komment. D.A. Funka. [Shor Heroic Epics. Vol. 1. Compiled, prepared for publication, and translated into Russian by D.A. Funk; introductory article, notes, and commentary by D.A. Funk.] Moscow: IEA RAN.

SHGE 2011= Shorskii geroicheskii epos. Tom 2: Shorskii fol'klor $v$ obrabotke O.I. Blagoveshchenskoi. Podgot. $k$ izd., vstupit. st. i komment. D.A. Funka. [Shor Heroic Epics. Vol. 2: Shor Folklore prepared by O.I. Blagoveshchenskaya. Prepared for publication by D.A. Funk; introductory article and commentary by D.A. Funk.] Kemerovo: OOO 'Primula'.

SHGE 2012 = Shorskii geroicheskii epos. Tom 3: Sybazyn-Olak. Vysporennaia Altyn-Torgu. Kara-Khan. Sost., podgot. $k$ izd., stat'i, per. na rus. iaz., prilozheniia, primech. $i$ komment. D.A. Funka; skazitel' V.E. Tannagashev. [Shor Heroic Epics. Vol. 3. Sybazyn-Olak: Altyn-Torgy, the One Won in a Dispute. Kara-Khan. Compiled, prepared for publication, and translated into Russian by D.A. Funk; articles, appendices, notes, and commentary by D.A. Funk.] Kemerovo: OOO 'Primula'.

SHGE 2013 = Shorskii geroicheskii epos. Tom 4: Shorskie epicheskie skazaniia v zapisiakh V.V. Radlova. Sostavlenie, vstupitel'naiia stat'ia, podgotovka shorskikh tekstov $k$ izdaniiu, perevod na russkii iazyk, primechaniia, kommentarii, prilozheniia D.A. Funka. [Shor Heroic Epics. Vol. 4. Shor Epic Stories as They Are Written Down in V.V. Radloff's Notes. Compiled and translated into Russian by D.A. Funk; introductory article, notes, commentary, and appendices by D.A. Funk; the Shor texts prepared for publication by D.A. Funk.] Kemerovo: OOO 'Primula'.

SHGS 1998 = Shorskie geroicheskie skazaniia. Vstupitel'naia stat'ia, podgotovka poeticheskogo teksta, perevod, kommentarii A.I. Chudoiakova; muzykovedcheskaia stat'ia i podgotovka notnogo teksta R.B. Nazarenko. [The Shor Heroic Stories. Introductory article, poetic text, translation, and commentary by A.I. Chudoyakov; musicology-related article and notations by R.B. Nazarenko.] Moscow \& Novosibirsk: Nauka.

Stoianov, Anatolii 1988. Iskusstvo khakasskikh khaidzhi. [The Art of Khakas Khaidji.] In: Altyn-Aryg: Khakasskii geroicheskii epos. [Altïn-Arïg: The Khakas Heroic Epics.] Moscow: Nauka, pp. 577-590.

Travina, Irina 1995. Shorskie narodnye skazaniia, pesni i naigryshi. [Shor Folk Stories, Songs, and Melodies.] Moscow: Kompozitor.

Trudy 1998 = Trudy A.I. Chudoyakova. [Works by A.I. Chudoyakov.] In: Deiatel'nost' Andreia Il'icha Chudoyakova i dukhovnoe vozrozhdenie shorskogo naroda. [The Activity of Andrey Ilich Chudoyakov and the Shors' Spiritual Revival.] Novokuznetsk: Pedagogicheskii Institut, p. 146.

Van Deusen, Kira 2000. The Shamanic Gift and the Performing Arts in Siberia. In: V. Kharitonova (ed.) Shamanskii dar. [The Shamanic Gift.] Moscow: Institut etnologii i antropologii RAN, pp. 223-242. Available at http://www.kiravan.com/ Articles/Shamanic_Gift_article.html, last accessed on 18 March 2019.

\section{INTERNET SOURCES}

http://corpora.iea.ras.ru/corpora/, last accessed on 14 March 2019. 


\title{
SOCIAL AND POLITICAL CRITICISMS EMBEDDED IN CHINESE MYTHS AND LEGENDS
}

\author{
HE Xiyao \\ School of English Studies \\ Zhejiang International Studies University \\ Hangzhou, China \\ e-mail: hexiyao@zisu.edu.cn
}

\begin{abstract}
Chinese myths and legends, as popular cultural products, may be subjected to the analytical methods of cultural studies, which is the approach this study adopts when investigating their complex relationship with Chinese society and history. In particular, the social and political criticisms embedded in these myths and legends are studied, and this is done through exploring the reasons for the prominence of the embedded criticisms in Chinese myths and legends, and sorting out the general trend of their development. The prominence is accounted for by the harsh censorship and the influence of the Chu spirit and Taoism on Chinese culture. ${ }^{1}$ In the development of these criticisms, four stages are marked, each (cor)responding to the historical circumstances and with its own distinct feature. The study concludes with the historicity of Chinese myths and legends; the criticisms are embedded in them and they, in turn, are embedded in Chinese society and history.
\end{abstract}

Keywords: censorship of culture, Chinese myths and legends, Chu spirit, cultural studies, social and political criticisms, strategies and tactics, Taoism

\section{APPROACH ADOPTED IN THIS STUDY}

Among the various approaches to the study of Chinese mythology - and of mythology in general - an important one that has persisted throughout the last century and has remained influential to this day is to study the complex relationship between mythology and society, i.e., how the two have affected, structured, and shaped each other. Malinowski is generally regarded as a pioneer of this approach, who asserted the "sociological charter" of myth - i.e., myth's function in supplying any given society with "a retrospective pattern of moral values, sociological order, and magical belief" (1948: 120-22). In the second half of the twentieth century, Malinowski's approach was furthered (and 
at the same time challenged) by the structuralists, who laid more emphasis on the persistent patterns and underlying structures which get repeated in myths from different times and places, as Lévi-Strauss has put it: "repetition has as its function to make the structure of the myth apparent" (1955: 443). The structuralist approach was skillfully applied to the study of Chinese mythology by Sarah Allan. In The Heir and the Sage: Dynastic Legend in Early China (1981) she studied the binary opposition between the hereditary and the moral principle in political successions, as revealed in early Chinese myths. Besides Allan, other scholars have also studied the relationship between Chinese mythology and Chinese society from a number of non-structuralist approaches in recent decades. For example, disagreeing with Allan's structuralist approach, Anne Birrell sticks to Malinowski's "sociological charter" in her analyses of several Chinese myths in order to reveal "a more powerful layer of mythic significance" (1993: 7); Mark Edward Lewis examines how, during the transformational period from the Warring States (the second half of the Eastern Zhou dynasty) to the early empire, tales of the sage kings constituted a "mythology of statecraft" in legitimizing state violence and establishing new order (Lewis 2009: 557); and Robin McNeal diverges from the others in exploring myths' relationship with not the traditional, but the modern, Chinese society, using monuments of mythical figures on the new Chinese landscape for case studies (McNeal 2012: 679).

Despite the different approaches and conclusions of these scholars, they nevertheless share one thing in common, namely, that in their studies they all focus on the constructive and formative functions of myths in society -i.e., how myths help to establish, enforce, and maintain order and authority. Such a focus has its merits and yields, but at the same time it could also lead to the neglect of the other side of the coin, that is to say, the deconstructive and subversive functions of myths - how myths also have the potential to mock, challenge, or even disrupt established order and authority.

This other side, however, has been duly noted by some Chinese scholars, most notably Yuan Ke and Tian Zhaoyuan. Yuan is generally regarded as the most distinguished and influential Chinese scholar in this field in the second half of the twentieth century. In his magnum opus, A History of Chinese Mythology, he forcibly argues that one distinctive characteristic of mythology is "a revolutionary attitude toward reality" (Yuan 1988b: 18), and in another work, Chinese Myths and Legends (1988a), he keeps highlighting this revolutionary attitude as he anthologizes Chinese myths and legends from different historical periods. Tian disagrees with Yuan about the revolutionary attitude, seeing it as an unnecessary yardstick in measuring myths. Instead, his focus is placed on the "conflicts" between myths in history, which reflect the conflicts between different social groups at large - for example, between different ethnic groups, between 
different ruling cliques, and between the ruling and the ruled (Tian 1998: 61-68). And it is within these conflicts that the deconstructive and subversive functions of myths are usually revealed. For example, Tian offers a brilliant analysis of how the royal power was derided and challenged through the blasphemy of royal myths by the folk (1998: 405-414).

The major reason why the deconstructive and subversive functions of myths, largely overlooked by many scholars in the West, were duly noted by Chinese scholars, such as Yuan Ke and Tian Zhaoyuan, was perhaps due to the influence of Marxist theories on the latter, most of whom have worked, or been educated, from the 1950s to the 1970s, when Marxism was the absolutely dominant ideology in education and researches. At the time, theories such as "class struggle as the drive for the progress of human society" were inculcated and applied in almost all philosophical argumentations, literary and artistic criticisms, and social and historical analyses. Even after the 1970s, Marxist ideology still left a trace in their research orientations and academic outlook, as can be detected in the terminology of their writings. With the emphases of Marxist theories on "revolution" and "conflict", it would not be difficult for them to notice the deconstructive and subversive side of myths.

What has been said above should not be taken as a negative evaluation of these Chinese scholars' efforts and achievements. On the contrary, my argument is that Marxist theories, when applied properly, can help us see things that might otherwise be overlooked. In recent decades, the discipline that has benefitted most from Marxist theories is perhaps cultural studies: many scholars of cultural studies are leftists influenced by Marx, and many theories in cultural studies actually derive from Marxist theories. In general, cultural studies pays special attention to the social and political tension embedded in cultural artifacts, production and phenomena, and views these as a field of power struggle, a field where different classes, genders, races, etc., vie with each other for expression, legitimacy, and even dominance, as Bourdieu has put it: "[t]he literary or artistic field is a field of forces, but is also a field of struggles tending to transform or conserve this field of forces" (1993: 30; italics in the original). And what is interesting to note is that when investigating the different forces in this field of struggles, cultural studies oftentimes takes sides not with the dominating, but with the dominated; not with the powerful, but with the powerless; not with the advantaged, but with the disadvantaged. In other words, it concerns itself primarily with the deconstructive and subversive in culture.

Chinese myths and legends, as products of culture, may also be subjected to the analytical methods of cultural studies, and that is the approach I have adopted in this study. In particular, this study focuses on the social and political criticisms embedded in these myths and legends. Such criticisms were some- 
times directly expressed, and sometimes only vaguely implied. But whatever the form of the criticisms, they certainly embodied a "structure of feeling" (Williams 1965 [1961]: 80) of those who created, transmitted, and revised these myths and legends. And it is the purpose of this study to uncover such a "structure of feeling". Besides, efforts are also made to sort out the different forms the criticisms took at different historical stages, in order to infer the general trend of their development and explore the mechanism of their interaction with the development of Chinese history.

\section{SCOPE OF THIS STUDY}

This article covers Chinese myths and legends from remote antiquity all the way down to the Qing dynasty. This is undoubtedly a very broad scope, and such a broad scope means that the study is only a general survey rather than a detailed and in-depth investigation of the individual myths and legends. As has been said before, the purpose is to infer a general trend, and further researches dealing with more details may be carried out along this line.

In terms of the object of the study, I have included both myths and legends rather than only the former because there is still much controversy with regard to the extension of 'myth' - i.e., what can and cannot be regarded as myth - which may vary tremendously from one scholar to another. For example, whereas Lévi-Strauss and E. B. Tylor see myths as restricted to 'primitive' societies, for Eliade and Cassirer even the moderns have myths of their own (Segal 2004: 29-55). A similar controversy has occurred in China. Early Chinese scholars tended to see myths as emerging only from the very ancient past; for example, in the 1920s Mao Dun defined myths as "stories widely told by the folk in remote antiquity" (2011 [1928]: 96). But in the 1980s Yuan Ke proposed his well-known theory of "myth in the broad sense", and incorporated into the category of myth not only stories from remote antiquity, but also legends, folklores, Buddhist and Taoist tales, mythic novels, etc., of the later ages (Yuan 1988b: 1-13). As can be expected, Yuan's theory was sharply criticized after its publication by the scholars who stuck to "myth in the narrow sense", some of whom went as far as saying that his theory had "led to many unnecessary deviations in the study of [Chinese] mythology since the 1980s" (Wu 2009: 9). But, interestingly, there were also scholars, such as Tian Zhaoyuan, who thought that Yuan's definition of myth was "still a bit too narrow" (Tian 1998: 60), and tried to broaden it even further. The scholar who went the farthest in that direction is perhaps Ye Shuxian, who regarded traditional Chinese culture as essentially mythologically encoded. According to Ye, myth is what permeated almost every aspect of 
traditional Chinese culture - customs, rituals, architectures, etc. - and ironically that is why it remained invisible to most Chinese people: "the traditional Chinese people never used the word 'mythology', because they had always been living in it - it dominated in all their ideas and behavior" (Ye 2010: 012).

Faced with such controversies, it would be safer for me to use 'myths and legends' rather than only the former, because the object of this study is not limited to the primitive society, but also ranges over the following dynasties. 'Myths' and 'legends' may be distinguished in terms of their origins if one adopts a narrow understanding of myth, but even if that is the case, it can still not be denied that the two share some important common features, two in particular: firstly, both contain, almost invariably, a 'fantastic' element, usually with some divine, supernatural or magical powers involved; secondly, both have been, or still are, popular among certain groups of people, with a wide and enduring circulation. Taken together, these features render myths and legends worthy research objects of cultural studies, because encoded in these fantastic tales is the structure of feeling of those who created, transmitted, and revised them.

\section{REASONS FOR EMBEDDED CRITICISMS}

As has been shown above, myths and legends, like other cultural products, are necessarily a field of power struggle. It follows that there would be social and political criticisms in myths and legends everywhere in the world. However, in the Chinese case, that critical element is unusually prominent, outshining its counterparts in most other cases. The prominence itself requires an explanation. Why were Chinese myths and legends so charged with criticisms? And what were the social, cultural, and political factors that led the Chinese to vent so much of their dissatisfaction and anger in these fantasy tales?

The above-mentioned prominence may be accounted for in two ways. On the one hand, in comparison with other societies, the traditional Chinese society was characterized by its harsh censorship of culture, which in general intensified one dynasty after another, culminating in the large-scale literary inquisition (文字狱) during the Ming and Qing dynasties. Censorship meant that the masses could not express their dissatisfaction and anger directly, but had to resort to some indirect devices, dressing up their criticisms in seemingly harmless cultural products and expressing their dissatisfaction and anger through implications and innuendoes. The device of indirect criticism was on record as early as in The Book of Songs, the first collection of poems in Chinese literature, dating from the eleventh to the seventh century BC. In this collection there is one 'air (风)' - i.e., a song circulating among the masses, called "Big Rat", in which 
the exploiters and extorters are symbolically referred to as a big, greedy, and loathsome rat. The first stanza of the poem runs as follows:

BIG rat, big rat,

Do not gobble our millet!

Three years we have slaved for you,

Yet you take no notice of us.

At last we are going to leave you

And go to that happy land;

Happy land, happy land,

Where we shall have our place.

(The Book of Songs 2005 [1937]: 309)

Instead of directly accusing and denouncing the exploiters and extorters, the song adopts a symbolic image to vividly capture their repulsive features and express the singer's disgust with them. This tactic is partly due to the limitation of freedom of speech, but at the same time it also enhances the critical effect of the poem - indirect insinuations, when exerted with skill and cunning, can be more effective than direct statements.

Although this song contains few fantastic elements, it is essentially adopting the same indirect device and embodying the same critical spirit as the myths and legends did. However, the song is not without a 'weakness'; namely, it is not indirect enough - it is actually not difficult to see through the symbol it adopts and the message it tries to convey furtively. Harsher censorship in the later dynasties meant that criticisms in this form were no longer acceptable. As a result, the criticizers had to resort to even more subtle and furtive means. To use Michel de Certeau's paradigm, the rulers adopted more and more powerful strategies in their ideological control, to escape the discipline of which the masses had to come up with even more ingenious tactics. The tension and interaction between the strategies and tactics largely resulted in the metamorphoses of the criticisms throughout Chinese history, as we shall see later.

If censorship also existed, in varying degrees, in other cultures and societies, then the other reason is more unique to China; namely, the influence of the Chu spirit and Taoism on Chinese culture. Chu was located in the southern part of China, and starting from antiquity it was culturally distinguished from the Central Plain (中原) area in the north, which later became the center of dynastic and imperial power. This cultural distinction was most saliently reflected in mythology, and was noted early on by some Chinese scholars. For example, in 1928 Hu Shi (1999 [1928]) observed keenly that in The Book of Songs, a literary output almost exclusively of the north, there was "no trace of mythology", while in the south, there were "abundant myths", as can be seen in the works such as 
The Songs of Chu. As for the reason for such a contrast, Hu attributed it simply to the "unimaginativeness" of the northerners and the "imaginativeness" of the southerners (1999 [1928]: 47-48). Another scholar, Mao Dun, agreed with Hu about the contrast itself but had a different view on its causes. According to Mao, the northerners were no less imaginative than the southerners and had created myths of their own, but most of these myths had fallen into oblivion during the Warring States period, and one important reason for that is the "historicization of mythology" (Mao 2011 [1928]: 4) - i.e., the gods and mythical heroes were humanized into historical figures, and the irrational elements in the myths were either rationalized or eliminated. During the historicization process, Confucius and his later followers played a pivotal role. Confucius was a practical and secularly-oriented man - among the four things he did not wish to discuss was "the supernatural" (Confucius 2003: 70) - and attached great importance to human relationships, seeing it as deserving more attention than ghosts and spirits. When one of his disciples asked him for a definition of wisdom, he answered, "[w]orking to ensure social harmony among the common people, respecting the ghosts and spirits while keeping them at a distance - this might be called wisdom" (Confucius 2003: 23; emphasis added). Because of his practical mind and secular orientation, Confucius deleted many 'irrational and ridiculous' passages when editing previous historical and literary works: "The Book of Songs was edited by Confucius, and Confucius did not wish to discuss ghosts and spirits" (Mao 2011 [1928]: 4). Besides, he also rationalized many mythical records through cunning interpretations (Yang \& An 2005: 33-34). A later historian, Sima Qian, who contributed considerably to the historicization process by humanizing the mythical figures, admired Confucius greatly and was largely following his steps. Thus, through the efforts of Confucius and his followers, a large bulk of myths were banished into oblivion and lost forever.

Fortunately, Confucius was from the north, and during its initial stage, the influence of his school was limited to the northern part of China. In the south another culture prevailed, namely, the Chu culture, out of which emerged another influential school - Taoism. Of the two progenitors of Taoism, Laozi was a native of $\mathrm{Chu}$, and Zhuangzi, whose philosophical outlook was strongly influenced by the Chu culture, was of Chu descent. Taken together, the spirit of the Chu culture and Taoism formed a vital antithesis of and counterbalanced Confucianism in shaping Chinese culture in a number of ways.

Firstly, as a northerner living in the Eastern Zhou Dynasty, Confucius inherited and tried to revive the Zhou culture which had thrived in the north but was on its decline at the time: "The Zhou gazes down upon the two dynasties that preceded it. How brilliant in culture it is! I follow the Zhou" (Confucius 2003: 23). However, the kingdom of Chu was culturally distinct from Zhou; as 
Feng Youlan notes, the Chu people were of non-Chinese origin, who only rose to prominence later (Feng 1952: 175-176). Consequently, in contrast to Confucius's admiring attitude, the Chu culture had always remained independent from and untamed by the Zhou culture. The kingdom of Chu was unwilling to submit to the authority of the Zhou emperor - King Zhuang of Chu once made an inquiry to a messenger from Zhou about the size and weight of the Nine Tripod Cauldrons (九鼎) in the Zhou palace, a provocative gesture that showed his intention to seize them and replace the Zhou emperor as the supreme ruler. This unruly and rebellious spirit was carried on by the later generations. At the end of the Qin dynasty, one leader of the rebellion, Xiang Yu, was from $\mathrm{Chu}$, and called himself “Overlord of Western Chu (西楚霸王)”. Even today, in the dialect of Hubei province, where the kingdom of Chu was largely located, there is still the expression “not surrendering to Zhou (不服周)", meaning "not willing to admit defeat'.

Secondly, in contrast to Confucianism's 'into the world (入世)' attitude and active participation in state politics, the Chu culture contained an 'out of the world (出世)' element, i.e., staying away from state politics and leading a reclusive life. Of all the recluses that Confucius met during his travels, many were from Chu (Feng 1952: 175). The most famous of them is perhaps Jieyu, the madman of Chu (楚狂). According to the Analects, Jieyu once passed by Confucius, singing him a song that ended with a warning that "[t]hose who participate in government these days court nothing but danger"; Confucius descended from his carriage wanting to walk to him, but he scurried away so that in the end Confucius did not get the chance (Confucius 2003: 215). By remaining detached from state politics, recluses such as Jieyu could adopt a non-cooperative and critical attitude toward the authorities. Later on this reclusive practice persisted throughout the dynasties and became an important element in Chinese culture.

Thirdly, unlike Confucianism's practical and secular orientation, the Chu culture abounded in witchcraft and supernatural beliefs, which produced and preserved plenty of myths and legends. It is precisely such a milieu that gave rise to the first great romantic poet in China, Qu Yuan, who wrote his despise of the political sycophants and sympathy for the masses into his imaginative verses. The most important contributor to The Songs of Chu, Qu Yuan, filled his lines with names and tales of the deities, through whom he launched a series of social and political criticisms. Thanks largely to $\mathrm{Qu}$ Yuan, The Songs of Chu became a major repertoire of Chinese mythology (Yang \& An 2005: 33-34).

However, the Chu culture and Taoism, which had prospered during the Eastern Zhou Dynasty, gradually abated since the unification by Emperor Qin Shi Huang; they were further relegated to a marginal position after Emperor Wu of Han's policy of abandoning all other philosophies and promoting only 
Confucianism (罢黜百家, 独尊儒术). One result of the relegation is that humanitarian rationalism, advocated by Confucianism, became the dominant spirit in Chinese culture, as Ge Zhaoguang (1987: 22) pointed out:

The unification of Qin and Han dynasties and the flourishing of Confucianism led to the gradual abating of the spirit of the Chu culture visà-vis humanitarian rationalism; the cultural tradition of humanitarian rationalism gradually replaced the romantic literary tradition as was represented by The Songs of Chu.

Nevertheless, despite the relegation and marginalization, the Chu spirit and Taoism were never completely banished from Chinese culture. They persisted, though in a metamorphosed form, in the Taoist religion, which began to flourish toward the end of the Eastern Han Dynasty. And the flourishing of Taoist religion became "one of the media for the revival of Chu spirit in literature" (Ge 1987: 22). Taoist religion, which had its origin in Taoism, preserved several elements from the Chu culture: on the one hand, many Taoist adherents led a reclusive life, stayed detached from state politics, and were more or less critical of the authorities; on the other hand, the Taoist religion was rich in imagination, with all its deities, esoteric practices, and elaborate rituals, which gave rise to abundant myths and legends. The combination of the mythical and the critical was manifest in the works of many romantic writers associated with the Taoist religion, most notably Li Bai. Li was a Taoist convert, and his poems contained many mythical figures and tales from Taoist religion, which were oftentimes employed to launch social and political criticisms. For example, at the beginning of the poem "Song of Mount Lu - To Censor Lu Xuzhou" he wrote, "I am just like from the Chu country a man queer, / Singing phoenix songs at Confucius with a sneer" (Tang Poems 2011 [2004]: 63), which shows a strong identification with the Chu spirit (through reference to Jieyu) and rivalry with Confucianism. In another poem, "Ascending Mount Tianmu in a Dream - A Song of Farewell”, after describing the carefree Taoist deities encountered in his dream vision, he lamented at the end of the poem when he woke up from the dream: "How can I lower brows and stoop before men in power / And have to keep my face and heart all the time sour!" (Tang Poems 2011 [2004]: 66). Here the non-cooperative and critical attitude toward the authorities is obvious; moreover, it derives from the poet's witnessing the carefreeness of the Taoist deities in his dream. Thus it can be seen that the Taoist religion preserved and fused the mythical and the critical spirit of Chu culture and Taoism, using one as the conveyor of the other. And since Taoist religion contributed greatly to Chinese myths and legends, it also brought the critical spirit in Chu culture and Taoism into the latter. 
The two reasons stated above - censorship on the one hand, and the spirit of the Chu culture and Taoism on the other - resulted in the prominence of the critical element in Chinese myths and legends. However, the external manifestations of that internal element did not stay the same throughout the dynasties, but were constantly adapting to the changing historical circumstances and went through a series of transformations, which are discussed in the next section.

\section{TRANSFORMATIONS OF THE EMBEDDED CRITICISMS}

This section examines the transformations of the embedded criticisms and the different stages they went through. In doing so, one has to organize the myths and legends into chronological order and map them onto Chinese history. This, however, is a daunting task because it is extremely difficult and in many cases impossible to date the origins of the myths and legends, especially the early ones. Most of them had been circulated and transmitted for centuries before they were recorded in written form. What is worse, the transmitters and recorders may have tampered with and distorted them according to social, political or personal needs; they may even have conjured up stories of their own and passed these off as centuries-old myths and legends. Such a possibility has been noted early on by Chinese scholar Gu Xiegang, who is generally regarded as the initiator of the systematic study of Chinese mythology. In his examination of the ancient records, $\mathrm{Gu}$ discovered that of the three Sage Kings in antiquity, the last one, $\mathrm{Yu}$, appeared the earliest in these records, during the Western Zhou dynasty, while the other two appeared later, toward the end of the Spring and Autumn period (the first half of the Eastern Zhou dynasty). Based on this discovery, Gu reached two conclusions: first, the myths and legends (such as those of the Sage Kings) in these records should be discerned and distinguished from history - in other words, there should be a demarcation between mythology and history; and second, these myths and legends were mostly fabrications of the later transmitters and recorders, rather than passed down from antiquity $(\mathrm{Gu}$ et al. 1981 [1926]: 59-66).

Of course, Gu's radical position, especially the second conclusion, is not without weaknesses, and was consequently criticized by other scholars. For example, Mark Edward Lewis keenly pointed out that Gu's argument "hinged on the exclusion of less canonical works from the later period" (Lewis 2009: 545), especially The Classic of Mountains and Seas, which is generally regarded as having preserved many myths from antiquity; and his rigid methodology and radical approach have been rejected by many scholars both in and outside China (Su 2012: 123; Birrell 1993: 13). 
In spite of Gu's weaknesses, his research is still of great value today in that it keeps reminding us of the potential risks and traps in the study of Chinese mythology. For the present study, it helps to highlight the difficulty in organizing the myths and legends into chronological order. Difficult it is indeed, but not altogether impossible. The 'tampering and distortions' mentioned above, though inevitable, do not necessarily have to be an obstacle in the study of mythology - Lévi-Strauss once defined a myth as "consisting of all its versions", all of which contain the same underlying structure (1955: 435). Actually, despite the discrepancies between different versions of the same myth/ legend, the core remains the same in most cases, and the recurring motifs stay more or less stable, forming a solid ground for researches. Furthermore, it would perhaps be more proper to regard the 'tampering and distortions' as the development and transformations of the individual myths and legends, which reflect the changing historical circumstances and the tension between different sides in the power struggle. As for the fabrications, they can be detected through a number of devices, such as meticulous textual analysis, inter-textual referencing, and comparison with living tales from the different ethnic groups. Chinese scholarship in recent decades has witnessed great accomplishments in establishing a chronology of Chinese myths and legends - most notably by Yuan Ke in A History of Chinese Mythology (1988b) and Tian Zhaoyuan in Mythology and Chinese Society (1998). In this study I am roughly following their chronologization.

Based on such a chronology, the transformations of the criticisms in Chinese myths and legends can be divided into four stages, each (cor)responding to the historical circumstances and with its own distinct feature, as is shown below. But it should be noted beforehand that the divisions between the four stages are not clear-cut, but rather there should necessarily be overlaps between the stages, as the transitions from one stage to another occurred only gradually, and sometimes tales of an earlier stage persisted long after the new stage had set in. But despite the overlaps, the general outline of the four stages is clear.

The first stage is, strictly speaking, a stage with no criticism in Chinese myths and legends. Manifest social and political criticism would only arise when there are large-scale inequalities, exploitation and injustice, which were almost non-existent at the time. Because of the low productivity, everyone had to work and share the output more or less equally, and the most important task was to get food out of nature rather than out of others' mouths. Moreover, as nature did not always provide enough food and oftentimes became harsh and inclement, how to cope with it became a primary concern, and that concern found its way into myths and legends. In other words, myths and legends from this stage deal primarily with the relationship between man and nature, 
rather than that between man and man. In these myths and legends, nature is often presented as an unfriendly and sometimes even hostile force. In general, there is a wish to overcome this force so as to make life easier, and sometimes a direct confrontation between man and nature can be detected. As Marx once put it, "All mythology masters and dominates and shapes the forces of nature in and through the imagination" (1986: 19). Even though his statement is a bit too assertive, it undoubtedly fits the majority of myths and legends from this stage. Tales such as "Nüwa patching up the sky" and "Great Yu controlling the flood" reflect the hardships the masses went through during natural disasters, and the consequent wish to be delivered by Gods or heroes; "Kuafu chasing the sun" and "The foolish old man removing the mountains" show the courage to emulate nature; and "Jingwei filling up the sea" even demonstrates antagonism against a hostile nature - the youngest princess of the Yan emperor, having been drowned by a hurricane, swore vengeance on the sea, and turned into the bird Jingwei, which incessantly carried pebbles and twigs and threw them into the sea, trying to fill it up. In these myths and legends, the tension is between man and nature rather than between man and man: few political authorities or human power struggles are detected. What is more, nature in these stories is not personified, but presented as nature itself. Thus it can be seen that myths and legends from the first stage were largely non-critical.

The transition from the first to the second stage occurred very slowly, since the productivity in the primitive society developed only in a piecemeal fashion. Nevertheless, the slow transition got reflected in myths and legends. I regard the tale "Yi shooting down nine suns" as marking that transition. According to the tale, at the time there were ten suns that shone simultaneously in the sky, which caused a great drought upon earth. In order to deliver the masses from the disaster, Yi the great archer shot down nine suns, leaving only one to perform its duty in the sky. From such a reading this tale is not different from the other tales about delivery from natural disasters. However, the interesting thing is that the ten suns were not just natural suns, but personified as the sons of Di Jun, God of the Eastern Heaven. What is more interesting is that Yi was actually a minor god sent by Di Jun to teach his mischievous sons a lesson but not to hurt them. Di Jun even provided Yi with the bow and arrows. However, when Yi arrived upon earth, the miserable scene infuriated him so much that he shot down the suns one by one; he had the intention to kill them all, and was only stopped because his last arrow was stolen by someone sent by the king on earth. And he was later banished from heaven because of his disobedience (Yuan 1988a: 289-298). I regard this tale as marking the transition from the first to the second stage because in it, the hostile force of nature is identified 
with repression from 'above', and Yi's disobedience shows a challenge of the authorities for the benefit of the masses.

The second stage witnessed the emergence and flourishing of criticisms in myths and legends, and a distinctive feature of this stage is that criticisms usually took the form of direct confrontation with the authorities. Criticisms appeared, on the one hand, because thanks to the advancement of technology and productivity, the masses were better safeguarded against the hostile forces of nature; and on the other hand, because inequalities, exploitation, and injustice emerged and intensified, which resulted in the antagonism between the masses and the authorities. These changes shifted the attention from the relationship between man and nature to that between man and man, the latter of which became a major concern in myths and legends. Another salient feature of these critical tales is the persistent revenge motif in them. The revenge is carried out, almost invariably, because an injustice has been done earlier by the authorities. Taken together, the confrontational manner and the revenge motif reflect, on the one hand, the appearance of large-scale inequalities, exploitation, and injustice; and on the other, the absence, or underdevelopment, of censorship, which gave the tale-tellers a free rein in venting their dissatisfaction and anger.

The earliest tale of this type is perhaps that of Xing Tian, who was originally a minister of the Yan Emperor. After the latter's defeat by the Yellow Emperor and the failure of the revolt by another former follower of the Yan Emperor, the infuriated Xing Tian went to challenge the Yellow Emperor himself. A fierce duel ensued, in which Xing Tian was decapitated and his head buried in Changyang Mountain. However, this is not the end of the story, for the headless Xing Tian did not surrender or die immediately, but, using his nipples as eyes and his navel as mouth, continued to fight with his axe and shield (Yuan 1988a: 151-152). Such an indomitable fighting spirit is typical of tales from the second stage. Xing Tian failed in the end, but in the later stories of this type, the revenge after the hero's own death often succeeded. For example, after having been killed by king Kong Jia of Xia, the ghost of Shi Men the dragon tamer caused a fire in the woods and frightened the superstitious king to death; and after being wrongly executed by King Xuan of Zhou, the ghost of Dubo avenged himself by shooting the king while the latter was hunting (Yuan 1988a: 291, 341). Stories of this type persisted until the Warring States period, when the motif of revenge was developed into highly elaborated plots, as is best represented by the story of Chi, the son of the great swordsmiths Gan Jiang and Mo Ye, which was later recorded in In Search of the Supernatural. After forging two swords, one male and one female, for the king of Chu, Chi's father knew that he was going to be killed by the king. So he buried the male sword and presented only the female 
one to the king, who killed him in a fit of wrath. Chi grew up, learned about the story, and decided to avenge his father. He dug out the male sword and set out. On his way he met a wanderer who promised to help him. Chi was glad and cut off his own head and gave it, together with the sword, to the wanderer. The latter then went to the palace and presented the head and the sword to the king, who was exhilarated, because he had formerly dreamed that he was killed by the young man, and consequently offered a thousand in gold for the young man's head. The wanderer advised the king to boil the head in a great cauldron, and the king did it. But the strange thing is that "even after three whole days and three nights the head did not break down, but rather leaped up in the boiling water to glare angrily at the King" (Gan 1996: 125). The wanderer then suggested a close inspection by the king for the head to "cook away", and when the latter drew near, he "unsheathed the male sword and struck the King's head off and into the boiling water. He then cut off his own head, and it too fell into the cauldron. All the heads then dissolved, so they could not be distinguished from one another". The three indistinguishable heads were finally buried together in the "Tomb of Three Kings" (Gan 1996: 125-126). What is noticeable in this story, besides the continuing revenge motif, is the ending when the three heads become indistinguishable, which possibly reflects a yearning to return to the classless society, when the kings were not yet distinguished from the masses and little exploitation or oppression existed.

Stories of the second type continued all the way till the Warring States period, but came to an almost abrupt halt in the Qin dynasty. This is probably because before the Qin dynasty, the political and cultural environment was comparatively loose, and the masses enjoyed more freedom of speech. However, after establishing the first unified empire in Chinese history, Emperor Qin Shi Huang carried out a series of policies to strengthen both the administrative and the ideological control over the empire, which resulted in what some scholars regarded as "one of the earliest totalitarian superpowers in world history" (Kulmar 2014: 165). The severest measure taken to achieve the latter purpose was the notorious burning of books and burying the scholars (焚书坑儒), which was unprecedented in Chinese history. As a result, ideological control tightened and tales about direct confrontation with authorities could no longer be tolerated. This forced the criticism in myths and legends to take a different form, and brought it to the third stage. Criticisms at this stage were more indirect, usually launched through tales about the unfair treatment and hardships the protagonists go through within the unjust and oppressive system; more often than not the protagonists are a pair of lovers torn apart by the repressive apparatuses and/or ideological dogmas. As Emperor Qin Shi Huang played a pivotal role in bringing about this transformation, there is a story of this type which 
is directly related to him - that of Lady Meng Jiang. According to the story, Meng's husband was conscripted by the Emperor to build the Great Wall, and died because of the hard labor. Meng, having heard nothing from her husband, set out to visit him on the construction site, only to find him dead when she arrived. Grief-stricken, she could not help wailing, and her wailing was so bitter that a part of the Great Wall collapsed, revealing the bones of her husband. The story is obviously critical of the repressive system, but it does so by telling a tragic story in order to arouse the readers' sympathy for the couple and hatred for the oppressors, rather than in a direct confrontational manner, as tales from the second stage did. What is more interesting than the story itself is the transformations it went through. As has been said before, the development and transformations of the individual myths and legends could reflect the changing historical circumstances and the tension between different sides in the power struggle, and this story is a very good case. Actually the embryonic form of the story had already existed before the Qin dynasty, yet at the time it was set in the Dukedom of Qi, and did not contain the wall-crumbling episode, which means that it was totally unrelated to Qin Shi Huang. However, during the transmission, the setting was transplanted and the new episode added, making Qin Shi Huang responsible for the tragedy (Idema 2008: 5-7). The development and transformations of this story show how the structure of feeling of the storytellers changed in accordance with the changing historical circumstances, and how the first emperor in Chinese history was remembered as a cruel and repressive figure.

The story of Lady Meng Jiang is one of China's four great folktales, the other three being "Butterfly lovers", "Xu Xian and his white-snake wife", and "Cowherd and weaving girl". What is interesting to note is that all of these tales are from the third stage and share the 'torn-apart-lovers' motif, although the force which tears the lovers apart varies from one tale to another. Of these stories, the one about the white-snake wife is undoubtedly the most interesting, as it also went through a series of transformations that changed its critical thrust. In the earliest record of this story by Feng Menglong in Stories to Caution the World, Lady Bai, the white-snake wife, is depicted as a seductive but demonic figure, which is quite different from the image with which most Chinese are familiar today. She stole silver from others' vault and clothes from a pawnshop, and cruelly threatened Xu Xian (her husband) that if he should betray her, she would "drench the whole town [Hangzhou] in a bloodbath and toss everyone from wave to wave in the river until all die violent deaths" (Feng 2005: 500). And in this version it is Xu Xian who placed the magic bowl over Lady Bai's head to capture her, because he wanted to get out of her control. Moreover, at the end of the story it is Xu Xian, not Fahai the monk, who collected donations 
and built the Thunder Peak Pagoda in order to trap Lady Bai underneath forever. At this stage the story was just a demon tale and Lady Bai's image a femme fatale. However, such an image was gradually transformed into a loving and devoting wife: the thefts turned into Lady Bai stealing the immortal herb from the Southern Pole Palace in order to save her husband, who was on the brink of death; and the threat to drench Hangzhou became the flooding of Golden Mountain Monastery (水漫金山寺), which was done in order to save her husband, who was trapped inside. At this stage the story put on a smack of confrontation, as Lady Bai became a daring figure who defied and challenged dogmatic rules and ideological boundaries for her loved one. This is especially prominent in the flooding episode, for Lady Bai "mobilized all creatures of rivers and seas, and Fahai responded by calling on all the protective deities of Buddhism for help" (Idema 2009: xvii), which reads like a rebellion from 'below' against the 'above'. In this sense, it is somehow even reminiscent of the tales from the second stage, although in the end it is the 'torn-apart-lovers' motif that triumphed, for Lady Bai was trapped beneath the pagoda by Fahai the monk, who represents the ideological authorities. However, this was not the end of the transformations, for after the story was performed on stage, the audience's longing for a happy ending induced the actors to make further adaptations, adding the role of a son born to Lady Bai and Xu Xian, who grew up to participate in the Imperial Examination (科举), won the top position, and finally liberated her mother from the pagoda (Idema 2009: xvii-xviii). It is noteworthy that the son's measure to liberate his mother is through participation in the state apparatus and serving the authorities (or becoming one of them), rather than defying and challenging them as his mother did. In this way the critical spirit of the story is much reduced.

The story of the white-snake wife allegedly took place in the Southern Song dynasty, but the recording and adaptations of it were done largely during the Ming dynasty, which made it overlap with the fourth stage. In this stage, criticisms in myths and legends were usually expressed in the form of satires. This is probably due to the literary inquisition - the persecution of intellectuals because of the allegedly instigative or rebellious passages in their writings, which were in most cases 'detected' only through far-fetched and distorted interpretations. Historically literary inquisitions had occurred occasionally throughout centuries, but it intensified at the beginning of the Ming dynasty. Zhu Yuanzhang, the founder of the Ming dynasty, attributed the downfall of the previous empire to its leniency, and his "abhorrence of free speech" prompted him to carry out a series of literary inquisitions (Luo 2011: 655). As a result, the Ming dynasty, "from the very beginning of its establishment, tried to cast the personality of 
men of letters in a slavish mould" (Luo 2011: 656). The situation deteriorated during the Qing dynasty, which was notorious for this practice, especially during the reign of emperor Qianlong (Mote 2003: 926-928). Such a tight control of speech forced criticisms to take even more subtle and surreptitious forms, and satirical tales, dressed up in harmless fantastic outfits, appeared to be a prime choice.

Two satirical works, one from each of these two dynasties, deserve special attention.

The Ming dynasty witnessed the appearance of Journey to the West, a highly satirical work in the form of a fantastic novel. Its protagonist, the Monkey King, is a figure that is familiar to almost every Chinese, and perhaps the most daring and rebellious character in Chinese literature. Although in terms of structure, the novel develops along the taming and domestication of the Monkey King, and his final achievement of Buddhahood, which symbolizes his incorporation into the ideological system, the subtext of the novel reads otherwise, for the Monkey King's submission is in many ways only apparent, and his aversion to oppression and ideological control persists to the very end. This is best demonstrated in the last chapter of the novel: immediately after achieving Buddhahood, the Monkey King asks his master to loosen the golden band (紧箍咒) - a symbol of ideological control - on his head:

'Master,' Monkey said to the Tang Priest, 'now that I've become a Buddha just like you, surely I don't have to go on wearing this golden band. Do you plan to say any more Band-tightening Spells to tighten it round my head? Say a Band-loosening Spell as quickly as you can, take it off, and smash it to smithereens. Don't let that Bodhisattva or whatever she is make life miserable for anyone else with it.' (Wu 2005: 1042; emphasis added)

The grudge against the Bodhisattva (authorities) and the hatred for the golden band (ideological control) is obvious here. Actually throughout the book Wu never stops mocking and deriding different forms of authorities: secular, divine, infernal, Taoist, Buddhist, Confucian.... Such mocking and derision finally result in the disruption and dissolution of authorities, which form the core of the novel's critical thrust:

Authority is vested in personages (mortal and immortal), laws (worldly and heavenly), things (weapons, magic treasures), and ideas and texts, particularly the Heart Sutra and the Buddhist scriptures. [But these] various kinds of authority are displayed and challenged, and ... in the ultimate conclusion of the journey, authority is completely dissolved. (Adams 2006: 117) 
In the Qing dynasty, the best satirical work in fantastic literature is undoubtedly Strange Stories from a Chinese Studio by $\mathrm{Pu}$ Songling, a collection of 491 supernatural tales, mostly related to ghosts, demons, foxes, and other spirits. Of these tales, there are many that are highly critical of his time. $\mathrm{Pu}$, an intellectual who had repeatedly participated and failed in the Imperial Examination, unlike the actors who adapted the story of the white-snake wife, cherished no unrealistic fantasies about the examination system, seeing it as nothing but a way the rulers used to control and enslave the intellectuals and select bureaucrats with no independent spirit. Therefore, there are quite a few pieces in the book which expose and satirize the examination system, showing how intellectuals who are upright and capable are almost without exception excluded from the state apparatus, while sycophants and hypocrites are selected. Besides, there are also pieces that reveal and mock the corruption and cruelty of the rulers in very subtle ways. For example, in a story called "Three Lives", a bureaucrat who has "often behaved immorally" during his lifetime is after his death reincarnated in the forms of a horse, a dog, and a snake in three consecutive lives, and suffers great pains as animals ( $\mathrm{Pu}$ 1979: 29-30). The whole story reads like a banal Buddhist tale of reincarnation, but for the comment the author attaches at the end: "Within the beasts are the spirits of kings and dukes and great ones; this is so because in the kings and dukes and great ones, there are also spirits of beasts" ( $\mathrm{Pu}$ 1979: 30). The most satirical piece in the work is perhaps "The cricket", which tells how the protagonist's comatose son became a cricket and was sent to the palace to please the emperor, who loved cricket-fighting. Although the story has a happy ending, with the protagonist rewarded and becoming rich, and the son recovering from coma, one gets a sense of black humor because the subtext of the story symbolically reminds one that the masses, like the crickets, are but playthings of the emperor and subject to his whims, just as the author puts in the comment: "A single step of the emperor may trample many people to death" (Pu 1979: 208).

Thus it can be seen that criticisms of the fourth stage largely abandoned the 'torn-apart-lovers' motif of the third stage, because even that may seem a bit obvious and, consequently, unacceptable. The adaptations of the white-snake wife story by the actors mentioned above may reveal, besides a wish to please the audience, also an act of self-censorship when confronted with the strategy of the state apparatus. Self-censorship, however, is not the only way to cope with the intensified strategy in ideological control; another way is to develop even more subtle and ingenious tactics to deliver the message in a more surreptitious way. And that is precisely what criticisms of the fourth stage did when resorting to satires. 


\section{CONCLUSION}

From the survey in the previous section it is clear that Chinese myths and legends are indeed a field of power struggle in which different forces play out. As historical circumstances changed, these forces also resorted to different strategies and tactics in their play, which resulted in the transformations of the criticisms in these myths and legends, just as Malinowski (1948: 122) once observed: "every historical change creates its mythology". Thus, Chinese myths and legends were not an isolated field; their development was closely associated with the development of Chinese history. The historicity of Chinese myths and legends is what this study ultimately rests upon, and that historicity is most saliently manifested in the embedded social and political criticisms.

Of course, this study is not without its limits. Because of the broad scope, it could only conduct a general survey, without going deeper in analyzing the individual myths and legends. Besides that, there are also a number of ways in which further researches may be carried out to deepen our understanding of this field.

Firstly, in studying the power struggles within the field of Chinese myths and legends, I focused on the struggle between the ruling classes and the masses. However, this should not be taken as exclusive, because there were certainly other struggles as well - for example, between different ethnic groups, different genders, or even different ruling cliques - which could be the subject matter of further studies.

Secondly, in studying the embedded criticisms, my approach was mainly 'responsive', i.e., focusing on how the criticisms responded to changing historical circumstances in their transformations. Another approach to this subject would be 'reactive', namely, analyzing the influence of these myths and legends on society in order to see how they helped to facilitate or even direct social transformations. For example, toward the end of the dynasties, leaders of revolutions would usually use myths and legends to rally the masses. This would also be a direction worth exploring.

Last but not least, as has been said before, the embedded criticisms ultimately derived from the dissatisfaction and anger of the masses. But these criticisms were not the only product of the dissatisfaction and anger; another important product is the creation of utopias, which also found their way into Chinese myths and legends. From the country which Great Yu allegedly visited, where the people, freed from hunger and labor because a magical fountain provided all the nutrition they needed, played music all day long (Yuan 1988a: 276); to the 'happy land' in The Book of Songs; to the Peach Blossom Land (桃花源) 
separated from the secular world and freed of its exploitations and corruption; to the Land of Decent Men (君子国) in Flowers in the Mirror, such a longing never stopped. Further studies may also be conducted with regard to this topic.

\section{NOTES}

${ }^{1}$ Chu was a kingdom during the Eastern Zhou Dynasty, when the authority of the Zhou emperor was on the decline and several powers vied with one another for supremacy. But unlike most of the other powers, which were located in the northern part of China, along the Yellow River, the kingdom of Chu was located in the south, along the Yangtze River. Culturally it was also distinct from the others in its Taoist tradition (as opposed to the Confucian tradition from the north) and its rich myths and legends, which were largely preserved in The Songs of Chu.

\section{REFERENCES}

Adams, Roberta E. 2006. Aspects of Authority in Wu Cheng'en's Journey to the West. In: Peter D. Hershock \& Roger T. Ames (eds.) Confucian Cultures of Authority. Albany: State University of New York Press, pp. 117-150.

Allan, Sarah 1981. The Heir and the Sage: Dynastic Legend in Early China. Taipei: Chinese Materials Center.

Birrell, Anne 1993. Chinese Mythology: An Introduction. Baltimore: The Johns Hopkins University Press.

Bourdieu, Pierre 1993. The Field of Cultural Production: Essays on Art and Literature. Edited by Randal Johnson. New York: Columbia University Press.

Confucius 2003. Analects: With Selections from Traditional Commentaries. Transl. by Edward Slingerland. Indianapolis \& Cambridge: Hackett Publishing Company.

Feng, Menglong (ed.) 2005. Stories to Caution the World: A Ming Dynasty Collection. Vol. 2. Transl. by Yang Shuhui \& Yang Yunqin. Seattle: University of Washington Press.

Feng, Youlan 1952. A History of Chinese Philosophy. Vol. 1. Transl. by Derk Bodde. Princeton: Princeton University Press.

Gan, Bao 1996. In Search of the Supernatural: The Written Record. Transl. by Kenneth J. DeWoskin \& James Irving Crump. Stanford: Stanford University Press.

Ge, Zhaoguang 1987. Xiang xiang de shi jie: Dao jiao yu zhong guo gu dian wen xue. [The World of Imagination: Taoist Religion and Classical Chinese Literature.] Wen xue yi chan [Literary Heritage], No. 4, pp. 21-30.

Gu, Xiegang (ed.) 1981 [1926]. Gu shi bian. [Critiques of Ancient History.] Vol. 1. Shanghai: Shanghai Classics Publishing House.

Hu, Shi 1999 [1928]. Bai hua wen xue shi. [A History of Literature in Vernacular Chinese.] Shanghai: Shanghai Classics Publishing House. 
Idema, Wilt L. 2008. Meng Jiangnü: The Development of a Legend. In: Wilt L. Idema (transl.) Meng Jiangnü Brings Down the Great Wall: Ten Versions of a Chinese Legend. Seattle \& London: University of Washington Press, pp. 3-23.

Idema, Wilt L. (ed. \& transl.) 2009. The White Snake and Her Son: A Translation of the Precious Scroll of Thunder Peak with Related Texts. Indianapolis: Hackett Publishing Company.

Kulmar, Tarmo 2014. On the Nature of the Governing System of the Qin Empire in Ancient China. Folklore: Electronic Journal of Folklore, Vol. 59, pp. 165-178. http://dx.doi.org/10.7592/FEJF2014.59.kulmar.

Lévi-Strauss, Claude 1955. The Structural Study of Myth. The Journal of American Folklore, Vol. 68, No. 270, pp. 428-444. http://dx.doi.org/10.2307/536768.

Lewis, Mark Edward 2009. The Mythology of Early China. In: John Lagerwey \& Marc Kalinowski (eds.) Early Chinese Religion. Part One: Shang through Han (1250 BC-220 AD). Leiden: Brill, pp. 543-594. https://doi.org/10.1163/ ej.9789004168350.i-1312.86.

Luo, Yuming 2011. A Concise History of Chinese Literature. Transl. by Ye Yang. Leiden: Brill. https://doi.org/10.1163/9789004203679.

Malinowski, Bronislaw 1948. Magic, Science and Religion and Other Essays. Boston, Mass.: Beacon Press. Available at https://monoskop.org/images/4/41/Malinowski_ Bronislaw_Magic_Science_and_Religion_and_Other_Essays_1948.pdf, last accessed on 21 March 2019.

Mao, Dun 2011 [1928]. Zhong guo shen hua yan jiu chu tan. [A Preliminary Study of Chinese Mythology.] Shanghai: Shanghai Classics Publishing House.

Marx, Karl 1986. Karl Marx: A Reader. Edited by Jon Elster. Cambridge: Cambridge University Press.

McNeal, Robin 2012. Constructing Myth in Modern China. The Journal of Asian Studies, Vol. 71, No. 3, pp. 679-704. http://dx.doi.org/10.1017/S0021911812000630.

Mote, Frederick W. 2003. Imperial China 900-1800. Cambridge, MA: Harvard University Press.

$\mathrm{Pu}$, Songling 1979. Liao zhai zhi yi. [Strange Stories from a Chinese Studio.] Vol. 1. Shanghai: Shanghai Classics Publishing House.

Segal, Robert A. 2004. Myth: A Very Short Introduction. Oxford \& New York: Oxford University Press.

$\mathrm{Su}$, Yongqian 2012. Shi jie yan guang yu zhong guo xue wen: Ye Shuxian shen hua xue si xiang lun lüe. [Global Vision and Chinese Learning: On Ye Shuxian's Thought of Mythology.] Xin jiang da xue xue bao [Journal of Xinjiang University (Philosophy, Humanities \& Social Science)], Vol. 40, No. 3, pp. 119-124.

Tang Poems 2011 [2004] = Wang's Translation of 300 Tang Poems 2011. Transl. by Wang Yushu. Beijing: China Intercontinental Press.

The Book of Songs 2005 [1937]. Transl. by Arthur Waley. Abingdon \& New York: Routledge.

Tian, Zhaoyuan 1998. Shen hua yu zhong guo she hui. [Mythology and Chinese Society.] Shanghai: Shanghai People's Press.

Williams, Raymond 1965 [1961]. The Long Revolution. Harmondsworth: Penguin Books. 
Wu, Bing'an 2009. Zhong guo shen hua bai nian fan si (xia). [A Reflection on the Study of Chinese Mythology in the Past One Hundred Years (Part Two).] Min jian wen hua lun tan [Forum of Folk Culture], Vol. 195, No. 2, pp. 5-15.

Wu, Cheng-en 2005. Journey to the West. Transl. by W. J. F. Jenner. Blackmask Online. Available at http://www.lxwc.com.cn/ebook-1237546-1.html, last accessed on 25 March 2019.

Yang, Lihui, \& An, Deming 2005. Handbook of Chinese Mythology. Santa Barbara: ABC-CLIO.

Ye, Shuxian 2010. Shen hua zuo wei zhong guo wen hua de yuan xing bian ma: Zou chu wen xue ben wei de shen hua guan. [Mythology as the Archetypal Code of Chinese Culture: Out of the Literature-Oriented View on Mythology.] Zhong guo she hui ke xue bao [Chinese Social Sciences Today] [Beijing] 12 August.

Yuan, Ke 1988a. Zhong guo shen hua chuan shuo: Cong Pan Gu dao Qin Shi Huang. [Chinese Myths and Legends: From Pan Gu to Qin Shi Huang.] Vol. 1. Beijing: People's Literature Publishing House.

Yuan, Ke 1988b. Zhong guo shen hua shi. [A History of Chinese Mythology.] Shanghai: Shanghai Literature and Art Press. 


\title{
CONTEXT- AND BELIEF-RELATED ASPECTS OF ESTONIAN RIDDLES
}

\author{
Piret Voolaid \\ Senior Research Fellow \\ Department of Folkloristics \\ Estonian Literary Museum \\ e-mail: piret.voolaid@folklore.ee
}

\begin{abstract}
This article studies the belief-related context (of use) of Estonian riddles. The study is based on archival records dating back to the end of the nineteenth and beginning of the twentieth centuries, which are concerned with solving riddles and primarily reflect the way that people in a peasant society thought. In addition to the studies that focus on texts of regular riddles (e.g. dealing with poetics or geographical dispersion), this paper discusses the beliefrelated functions of riddles that have been minimised during cultural changes. The study gives consideration to links between Estonian archival material and archaic mythological riddle forms (neck-riddles, kennings), taboos and restrictions related to solving riddles as well as to combinations of belief-related backgrounds with playful and entertaining aspects. Belief-related backgrounds are confirmed by the syncretic relation of riddle solving to everyday tasks (e.g. solving riddles in the autumn and winter periods as part of calendar traditions, riddles in marriage proposals and wedding traditions), which reveal connections to both sacral and profane changes of time, including economy; on occasion, solving riddles served to ensure personal luck and to promote one's household and work.
\end{abstract}

Keywords: belief aspects of riddling, context of riddles, Estonian riddles, neck riddles

\section{INTRODUCTION}

Riddles as a separate research topic have been studied in Estonia since the 1990s. One of the principal responsibilities of the working group for short forms, which used to operate at the Institute of the Estonian Language and in 2000 continued under the Department of Folkloristics of the Estonian Literary Museum, was the digitalisation of traditional (or proper) riddles and compilation of the publication Eesti mõistatused (Estonian riddles) (EM 2001, 2002) in the scholarly series on Estonian folklore, Monumenta Estoniae Antiquae, and an online database comprising 100,000 texts (Krikmann \& Krikmann 2012). 
The most important theoretical studies on Estonian traditional riddles are approaches to genre issues, papers on the geographical distribution of riddles, and the part dedicated to riddles in Arvo Krikmann's study Sissevaateid folkloori lühivormidesse (Insights into short forms of folklore) (Krikmann 1997) and his lecture material (Krikmann 2000), a four-part monograph on the sources of Estonian riddles (Saukas 2005a, 2005b, 2007, 2009), and an analysis of what makes riddles sound good (Sarv 2003).

The scarce and rather random records on the traditional use of Estonian riddles, typical riddle solving situations, etc., dating back to the final quarter of the nineteenth century, indicate that riddles once had a wide social and cultural background in Estonia. Riddles have not been used by children alone, and their function has not merely been that of entertainment; they have also been related to a wider view on the world (see Oinas 1984: 162; Viidalepp 2004: 70). This notion is confirmed by observations on riddle material from several other nations. In her studies, Annikki Kaivola-Bregenhøj (1996: 10-16, 2001: 92-127) analyses the contexts of both traditional riddles and riddle jokes, and describes them through social situations and culture. She views riddles as an enigmatic verbal genre and observes them in the social relations of jokes and entertainment as a so-called icebreaker in tense situations, and as a means for creating and strengthening the atmosphere of eroticism. Cultural context plays an exceptionally significant role in the cognitive process of riddles. The ambiguity that is characteristic of riddles can be so empirical and culture-specific that outsiders have no way of understanding it (Kaivola-Bregenhøj 1996: 14), but it can also be important in the socialisation process of related parties (McDowell 1979: 223-226; Abrahams 1968: 155, etc.) and express ritual unity.

In this article I will focus on the contextual archival material of riddles and draw on about 500 archival records to analyse the social backgrounds that have supported the process of solving riddles, and study the way that those social backgrounds have entwined with belief-related backgrounds. The study focuses on the issue of belief-driven objectives and meanings of riddles. I will take a close look at the known functions of older, so-called traditional or proper or classical Estonian riddles (magical-religious functions, use of riddles in ritual and playful contexts, etc.) that distinctly oppose several principal functions (entertainment, social criticism) of the newer riddle material.

\section{ARCHAIC FORMS - NECK RIDDLES AND KENNINGS}

Archaic forms of riddles have played an important part in mythological texts. It has been said that the sacred or dangerous nature of riddles is reflected in that in mythological or ritual texts they nearly always appear as so-called neck 
riddles or capital riddles, which must be solved as a matter of life or death, as the player's life is at stake (Huizinga 1949: 108).

Archer Taylor (1951: 1) believes that neck riddles are truly hard nuts to crack for people to whom they are posed as they narrate an event known only to the poser of the riddle. Seemingly impossible riddles were posed, for example, to people who had been sentenced to death, thereby presenting them with a chance to save their neck from the noose by solving such riddles. The birth of riddles with a similar function, known all over the world, dates back to the creation of mythologies of a number of nations across the world. One of the most archaic neck riddles (or capital riddles) is the so-called riddle of the Sphinx, which originates from the story of King Oedipus as told in the mythology of ancient Greece: What creature goes on four feet in the morning, on two at noonday, on three in the evening? Man. In childhood he creeps on hands and feet; in manhood he walks erect; in old age he helps himself with a staff (Hamilton 1942: 257). The logical distribution of this riddle should be from myth (folklore) to literature, but the internationally known riddle motif probably originates from Sophocles' tragedy and not directly from the myth (Lill 2004: 251). In Estonian archival material the same riddle is represented in 249 records from various regions, and has been classified as type No. 263 in the academic publication of Estonian riddles: Four legs in the morning, two by noon, and three by night? A human (EM 2001: 261). There are no records of this riddle type in Estonian archival material in relation to its mythological context or its being presented in a narrative, but similar functions can also be seen in Estonian riddle stories. The 'neck riddle subject' is directly represented in the stories registered under No. 927 in the Tale Type Index (ATU) that was created by Antti Aarne, improved by Stith Thompson, and later on by the German folktale scholar Hans-Jörg Uther. The scheme of the riddle type known as 'Out-Riddling the Judge' (ATU 927) is as follows: The accused is set free when the judge cannot solve the riddle propounded to him by the condemned person (by a relative of the condemned). The riddle refers to extraordinary or accidental events that happened to the person setting the riddle, and thus is unsolvable for outsiders. There are also records in the Estonian Folklore Archives, in which the hero of the story must come up with the right answer to a question to either escape from imprisonment or save their own life or the lives of their loved ones (see Voolaid 2005: 36-38).

The sacral and religious-mythological background of riddles and their solving is also implied in the Old Norse Poetic Edda, written down in the ninth to tenth centuries, in the form of metonymic-metaphorical circumlocutions that are based on kenning-like tropes and have been used, among other things, as euphemisms for mythological creatures, kings, warriors, women, body parts, ships, weapons, 
the sea, and gold, as well as in relation to battlefields and hunting (Kuusi 1992: 107). Estonian chain riddles also consist of kennings ${ }^{1}$, but there is no proof of the existence of any genetic relations between Old Norse kennings and Estonian kenning-like writings (Virtanen 1966: 14). The Exeter Book, which dates back to approximately the same period, the tenth century, features an impressive collection of riddles - 95 Old English riddles in verse form; through their use of imagery and symbolism, they can be treated as manifestations of Anglo-Saxon sacral knowledge and have inspired researchers to reconstruct Anglo-Saxon sacral history (Alexander 1982 [1980]; Williamson 1977).

\section{THE MAGICAL SEMANTIC FIELD OF RIDDLING IN AUTUMN AND WINTER}

In the work calendar of Estonian peasants, riddles constituted a part of the autumn and winter periods, when the end of threshing and flax processing marked the start of indoor jobs in the winter season; women of the household started with handicraft while men headed out to chop wood and haul it out of the forest (Hiiemäe 1994: 5). The end of the 'economic' year of farming left enough time to celebrate this and to ensure good crops for the coming year. In his 1965 dissertation Richard Viidalepp also pointed out that the stories told at twilight in the autumn and wintertime often entailed solving riddles, and that telling stories and riddling at twilight has been thought to have caused or promoted something (Viidalepp 2004: 70). According to archival records, solving riddles served as a magical act that was supposed to affect next year's crops. It was also linked to the variety of the most important element of peasant societies - the food. Folk belief assumed a riddling habit to keep the food on the table or, to put it more poetically, 'to keep the spoons from getting lost'. People's diet quite literally depended on the well-being of domestic animals, which was thought to be in correlation with riddling. Felix Oinas (1984: 166) has highlighted the strict regulations regarding the posing of riddles - it was not permitted to solve riddles in the late-winter season when there were young animals in the barn, because it was thought to hinder their growth and development. Estonians as well as other nations regarded riddles as spells that could enhance or harm the growth of animals and crops.

Significant folk calendar celebrations in the autumn and winter seasons in Estonia include St. Martin's Day and St. Catherine's Day (10 and 25 November respectively) with their rich belief-related backgrounds. The tradition of celebrating the eve of the holidays by going out and visiting other households dressed, accordingly, as mardisant (Martinmas mummer) or kadrisant 
Figure 1. Virve Murumaa is writing down riddles from Juhan Rääk in Simuna Nursing Home. Photograph by Ülo Tedre 1950 .

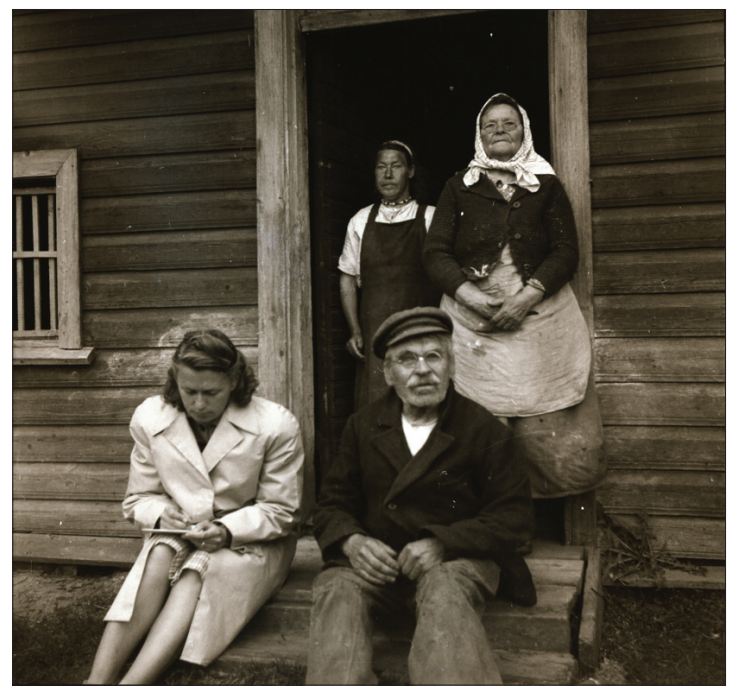

(St. Catherine's Day mummer) is still known today. Archival records present documented cases of the use of riddles in the peasant culture in dialogues between Martinmas mummers and the families they visited (Hiiemäe 1994: 68-71), and it can be argued that the folklore repertoire of the mummers who celebrate the holidays today and did so in the last decades of the twentieth century includes traditional as well as more recent types of riddles. For example, folklorist Mare Kõiva has described the mummers who visited her family in 1992 (RKM II 461, 439-452) as well as the folklore they used.

She recorded the performance of five groups of mardisandid and two groups of kadrisandid. The communication of two groups of mardisandid and both groups of kadrisandid also featured riddles, which were posed to the family (altogether 27 riddles), but the family also tested the knowledge of the mardisandid and kadrisandid in the dialogue that ensued. I can recall from the experience of my own family that on St. Martin's Day in 2003 our house was visited by a group of mummers who were complete strangers to us, and who took some papers out of their bag after their performance of traditional St. Martin's Day songs to test the family's knowledge on droodles collected and published by folklorists. This kind of a riddle-dialogue creates opportunities for communication with the family. In the age of smart devices, contemporary mummers use smartphones to read out texts. Therefore, riddles have performed a belief-laden and communication-enhancing role in traditional celebrations of St. Martin's Day and St. Catherine's Day (see also Voolaid 2005: 44). The mummers in modern microdistricts, which are comprised of multi-storey apartment buildings, are usually unknown to the family, and riddles are a good neutral way to help reduce the awkward tension for visitors as well as the family who is being visited. 


\section{RIDDLES IN MARRIAGE PROPOSALS AND WEDDING TRADITIONS}

In archaic neck riddles an incorrect answer to a riddle could mean that you had to give up your life, but according to records collected from people, correct/ incorrect answers could also affect a person's future in traditions surrounding marriage proposals and weddings. Parents of brides-to-be were said to have warded off unwanted suitors from the family by giving them complicated riddles just as in fairy tales. This is illustrated by the following record taken down by Mall Proodel (Hiiemäe) in 1956.

When a young man came to propose, the girl's parents gave him a riddle to solve. If he gave the right answer, the marriage proposal was a success, but if he was 'at a loss' and displayed his stupidity, the proposal was not accepted and the suitor had to try his luck in another household. If the girl's parents found the suitor to be suitable, they gave him an easier riddle to solve. Pauliine Kiver explains that it remains unclear whether this practice was followed in these parts during the twentieth century, but it was commonplace at the end of the nineteenth century.

RKM II 61, 55 < Iisaku, Mäetaguse

Riddles were part of the wedding tradition in which the bride distributed the contents of the dowry chest to the guests. This was followed by promises of presents from the latter (Tedre 1973: 87). The people giving the 'gifts' were primarily close family and other relatives, and the promises were metaphorical or humorous. So the father-in-law gave to the bride 'a meadow to cut six times a week' (i.e. cleaning the house), and the sister-in-law gave her 'carrying poles to share and bucket yokes in twain' (i.e. tending the animals). Gifts also included a 'pole stallion' (cat), 'a ship that sales the wind and seven fathoms of silken string' (cradle and napkins), 'a meadow to cut four times a year' (sheep), 'a harrow that harrows backwards' (chicken), 'a plot for a strawberry bed and myself to pick them for the day' (promise to become a godparent), 'a hat for the moon and a wreath for the sun' (a hat if it is a son and a coif if it is a daughter), etc. The following note by Daniel Pruhl from 1894 gives us an idea of the wedding customs:

Once the gifts had been handed out and the process of giving money was finished, the best man started to order a gift for the newlyweds. Saying something like: 'Here we have two birds about to build their nest and we should aid them in doing so'. Whoever wanted to give a gift then stepped forth and made a promise and was given a beer or a drink and a blessing as well. The gift was not revealed directly, but referred to in riddles so 
that the person giving a cradle would say 'I'll give you a boat', and the person giving a beehive would refer to a barrel full of shocks. A dozen child's rags or half tissues, a chicken that works backwards; a child's hat, an uncovered head is unseemly; a child's coat, small children look lovelier with a coat; a foal, for the first son to ride to church; a calf, who shall be the milker or the ploughman. A sheep to undress four times a year, etc. Some also said: I'll give you a sheep, I'll give you a cow, meaning I'll give you a 'wagon'; some young men also said they'll give a wedding to the young couple, or 'a wedding returned'. And so, most wedding guests gave this and that and each person tried to find the best words for their gifts - the funnier the better.

E $5167<$ Haljala Parish

According to Estonian folklorist Ülo Tedre, there were never any wedding gifts at all, except for the bride's dowry and the donations made by the godparents (ibid.: 88).

\section{'PUNISHING' THOSE UNABLE TO SOLVE RIDDLES}

The social functions of the riddling genre are also highlighted in a number of riddling games, which include a more archaic and belief-related game from Finland, called 'Going to Hymylä' (hölmölän matka - 'a trip to Stupidville'2), whereby the person unable to solve the riddle was sent, by using Kalevala-metre verses, to Hyvölä, Himola, Hölmölä, Huikkola, or Hymylä (Virtanen 1977: 80, 1984: 77; Kaivola-Bregenhøj 2001). There are a handful of records of such acts from Viru County, the southern region of Tartu County, and from Võru County. The game meant that respondents who were unable to guess a certain number of riddles would become the laughing stock, and would be sent someplace far away in verse form to 'look' for the answers.

There is a report from Kadrina Parish in Viru County, sent by Johannes Sõster in 1910, according to which anyone who was unable to solve a riddle was sent to Üiküla; based on the report by Armilda Hallik, they were sent to Uikkala:

In the past it was fashionable to solve riddles. When two to three people got together, they started riddling. Whoever was unable to solve seven riddles was sent to uikkala: Uih, aih, uikkala, put his leg on the doorknob and shat five barrelfuls. Whoever fails to solve the riddles has to eat it. ERA II 166, 241 (17) < Iisaku Parish (1937)

We can quite safely assume that 'uikkala' refers to a small village in Ida-Viru County called Uikala (see Voolaid 2017: 121). We can probably draw parallels 
with the Finnish riddling game because both Üiküla and Uikala as place names in Estonia seem to be Finnish loans (compare to Huikkola, which has a similar sound). Sending people who struggle to solve riddles some place to retrieve the right answers has made the act of posing riddles more playful and ritual. The sequence of sending people away employs long verse forms using alliteration and assonance and fantasies (probably conjured up 'on the spot') about what will happen to a slow-witted respondent.

In the southern region of Tartu County (e.g. in the parishes of Võnnu, Kanepi, Sangaste, Otepää, Maarja-Magdaleena, Urvaste, Setu, Vastseliina, and TartuMaarja) it was common to send people who could not solve riddles to Rasina. The writings do not specify why it was namely Rasina. But we do know that the village of Rasina is one of the oldest in the Mooste municipality in Võnnu Parish and was first mentioned in the records of the Bishopric of Dorpat under the name Rassinal in 1403; Rasin Manor was first mentioned in 1611 (EE 1995: 37). The village is located on a crossroads of gravel roads leading to Mooste (about 8 km from Rasina) as well as Tartu (ca. 40 km), Räpina (ca. 18 km), and Ahja. There are a total of 20 reports from the period from 1895 to 1992 about being sent to Rasina. The earliest of these from Jakob Hurt's correspondents date back to 1888 :

Those unable to solve the riddles shall be sent to the old hag in Rasina to retrieve the answers. Take the brake as your horse, the mortar as your carriage, the dog's tail as your stick, the cat's tail as a whip, two scones made of chicken shit, and go away to Rasina. An old hag in Rasina was putting bread in the oven and her daughter looked over the fire; their little dog in the yarn basket on top of the oven started to bark. The old hag said to her daughter: 'Go see who is coming, the dog is barking.' The daughter then went to see and said: 'There's a man / woman there with his / her wits about her.'After that the person asking the riddles enters, greets them and starts explaining the riddles.

H III 11, 491 < Kanepi, Johann Väggi

Timo Leisiö (2000: 273-283), a Finnish music anthropologist, has observed the historic spread of this archaic phenomenon across Finland and interpreted this game as part of a shamanistic practice, finding that this post-shamanistic game of riddles grew out of a plausible ritual. Hymylä and other place names in the game originally symbolised a kind of underworld / other side where the shaman would go using supernatural powers to get answers needed in his society (this world) (ibid.: 284). It is probably no coincidence that John R. R. Tolkien, who was an expert on Anglo-Saxon language and mythology, included the concept of ancient and sacred riddles in his Hobbit tale (Tolkien 2006 [1937]: 81-105). In the riddling game between hobbit Bilbo Baggins and Gollum, the former 
wins by cheating (asking as his final question: 'What has it got in its pocket?') and as a result his opponent must act as his guide.

According to Savely Senderovich (2005: 59-64, 118), riddles in their archaic form are based on the following paired mechanisms: explicit and implicit, manifest and latent, innocuous and taboo, common and esoteric, and declared and silently implied. Ana Stefanova (2007: 134) has employed Émile Durkheim's (1915) theory of anthropological rituals to the study of riddles, dividing the world into sacral (holy) and profane (secular), which can be defined through their polarising nature. The level of questions and experiences in sacral and profane riddles is fundamentally different. In the first case, the riddle is surrounded with a conscious supernatural, ritual or symbolic meaning. Profane riddles, on the other hand, lack the ritual (religious or ceremonial) environment and highlight the 'concealed' meaning; the questions are routine in meaning and presented in a colloquial manner. There is a discrepancy between the conscious and unconscious in profane riddles. Tatiana Vladykina (1998: 42) has studied the syncretism of calendar rituals at greater length and has shown how riddles are used to describe the ways of constructing the world. In the Udmurt folk calendar, riddling takes place during the transition period from the old year into the new, and relates to the alternation of sacral and profane periods. The solving of riddles stimulates wisdom and the physical strength of people in the magically hazardous transition period.

Psychoanalyst Albert Rapp has stated that any kind of riddling is a 'mental duel' and that there are records of riddling competitions in history, bets relating to riddles, etc. Battles of wits were originally not regarded as entertainment - it was one of those more humane and refined forms of duelling that people used to establish their hierarchical relations; a sharp and witty mind was also more useful for survival in natural selection (Rapp 1951: 21). Popular modern-day quiz shows (e.g. Who Wants to Be a Millionaire, Jeopardy, Are You Smarter Than a 5th-Grader?) are closely related to the mental duels comprising questions and answers. Every adult can apply to take part in television shows. Giving correct answers to different questions may help improve the players' financial situation, but it is also a great way to stand out with your wits (or dim-wittedness) in front of a wider public and market your personal brand. Different quiz show formats have helped popularise a number of Estonian so-called media personalities (e.g. Hardi Tiidus, Valdo Pant, Toomas Uba, Hillar Palamets, Indrek Salis, Jevgeni Nurmla, and others). Therefore, it is not accidental that the Estonian public has had great interest in television competitions testing the wisdom of politicians, which are organised, for example, before general elections (e.g., the party quiz show held on the national channel, Estonian Television, on 23 February 2011 drew in an audience of 120,000 people (TNS Emor, TV Audience Meter Survey, period 23 February 2011)). 


\section{RIDDLING AS A FORBIDDEN AND DISGRACED ACTIVITY}

It is curious that the records on riddling in Estonian archival material are very contradictory. On the one hand, it was as if compulsory for peasants to pose and solve riddles in the darker autumn and winter seasons to ensure the availability of food and the well-being of cattle, but on the other hand, based on some records, riddles have also been condemned - riddling has been considered as a sin and it has been related to evil forces as is illustrated by a record written down by August Voldemar Kõrv, dating from 1925.

A farm hand said that it was not allowed to solve riddles because it was supposed to be a sin. Once upon a time, when people were solving riddles, a bloody hand fell to the ground and told the people there to riddle it.

E, StK 27, 123 (4) < Koeru

'Bloody hand' motifs such as this make up quite a distinct type of legend, i.e., a merger of a belief/viewpoint and the 'confirming' narrative.

There are certain types or archival records that give testimony about riddles as something that is often considered inappropriate and depreciative, and such records can be summed up in a proverb-like report taken down by Aleksandra Grünvald-Univer in Karksi Parish in 1936: 'Riddles are said to be like the Lord's Prayer for the Old Nick' (ERA II 138, 459 [5]). Records related to this topic reveal hints of a pejorative attitude towards riddles and posing them. On the basis of these records, riddling seems to be something of a medium between the real world on the Earth and supernatural satanic forces, a tool that can summon evil entities from the spirit world, e.g. the Old Nick. This is claimed by Jakob Ploompuu and Hans Rebane from Kuusalu Parish (dated 1892) and Kristjan Põldmäe from Jüri Parish (dated 1895) in their letters to Jakob Hurt:

No good is said to come from riddling too much at a time because it is said to attract the Old Nick. That is why people are reluctant to talk about riddles and old customs.

Once upon a time, two women were riddling in a little sauna in the woods long into the night. All of a sudden a big black finger appeared from under the floor and a gruff voice called out: 'Riddle me, riddle me!' The women took fright and never told riddles again.

(This is probably why it is difficult to get lore, and especially riddles, from people, as this might attract Old Nick's servants. Throughout centuries, Christian teaching has implanted thoughts into people's minds that it is a sin.)

H II 40, 442/3 (4) < Kuusalu Parish 
It was not allowed to tell old tales or riddles in the evening because it was said to cause the fiend to show itself at night. (To scare people.)

H IV 5, 42 (7) < Jüri Parish

The supernatural characters mentioned in these reports include: Old Nick, a fiend, a yellow-faced hag, the Devil, ghosts, and Old Barney. There are even records on the pagan nature of riddles from the not-so-distant past: in 1969, folklorist Pille Kippar wrote down the following record in Rakvere Parish:

It is said that riddles were Old Nick's doing. If someone riddles then Old Nick was said to lurk around the room at night, saying: 'Where's my book, where's my book? What have you been up to with my book?' and that meant that riddling was banned.

KKI 49, 229/30 (23)

There are a couple of dozens of stories that have been written down in the archives, which exemplify riddling as an activity that has occasionally been seen as forbidden and disgraceful. These stories are horror stories by nature. Whereas horror stories are usually characterised by a violation of some sort of a rule/taboo (children going to places that are out of bounds or purchasing forbidden items), the unexpected manifestation of an evil person (thing) in the house or by an item in the house turning evil (Kõiva 1996: 169), the texts with the below stereotypical plot scheme fit the horror genre perfectly. In a simplified form, the structure of these kinds of records is the following. People pose riddles to one another in a dark farmhouse late at night, when all of a sudden a bloody hand, the head of an animal or something else is put through the window or door and a strange voice calls out: 'Riddle me, riddle me!' Of the above characteristics, the stories feature a violation of rules (riddling without permission) as well as an unexpected appearance of an evil thing (a demon, in this case) in the house. Let us take a closer look at some archival records on this subject. In 1895, Johannes Reinthal sent the story below from Rapla Parish to Jakob Hurt:

Once upon a time, children were indoors posing riddles to each other. Then all of a sudden a bloody hand was put through the window and a strange voice called out: 'Riddle me, riddle me!'

H I 7, 122 (13)

As was mentioned above, the prime time for telling folktales and posing riddles in the peasant society was evenings and twilight hours of autumn and winter (see also Viidalepp 2004: 45-54). Pursuant to this notion, dark nights create the best atmosphere for telling these kinds of horror stories. It is the time that the supernatural doorway to the realm of fantasies opens up to the human 
mind in its most vivid and excited imaginary state. Furthermore, the plot of the story is closely linked to the practices of riddling activities during those times, adding even more excitement. The time and place of these stories are defined (on a dark night in the farmhouse), yet their credibility is diminished by the fact that they begin with the indefinite phrase 'once upon a time', much like fairy tales. Just as in the previous report, there are temporal and spatial similarities in the text written down by Johan Reimann in 1896 :

Once upon a time, on a Thursday night, the children were sitting on the floor, posing riddles for one another to solve. All of a sudden the door opened and a big, truly enormous bloody fist appeared in the doorway, and a voice said: 'Riddle me, riddle me!' This scared the children and they stopped riddling, prompting the fist to disappear as well. In some places it is considered a sin to solve riddles on Thursday and Saturday nights and that must be why the Devil showed its fist.

H I 10, 88 (4)

At least in certain regions the Church can be held accountable for the attitude according to which riddling is regarded as a sin. Such a derogatory attitude is evident in the record written down by folklore collector Enda Ennist in 1937.

We didn't do much else here but learned the songs by heart. There were no riddles or other stories like that. God save us from those!

ERA II 159, 494/5 (8) < Ridala

The same idea is expressed by Ilja Daniel's report from 1937:

Riddling was forbidden during church.

ERA II 160, $501(26)<$ Setu

Astra Lauk from Kadrina Parish, a student of Tartu Reaalkool (Tartu Gymnasium of Sciences), also paints a vivid picture of the ban on riddling on Saturdays and the subsequent punishment - appearance of the Devil - in her writing dating from 1939:

But on Saturday nights it was forbidden to tell old stories. On Saturday nights it was customary to go to the sauna, and then afterwards older people started to read the Bible. Children had to sit tight and listen quietly, but when they were feeling mischievous, they all sneaked off to the old threshing room. And then it was time for riddling, Father and Mother wouldn't know. And they started riddling. They went on and on posing riddles to one another. Then, all of a sudden, a black man jumped out and started skipping about on the floor, yelling out: 'Riddle me, riddle me - what am I?' He had horns on his head, a big long tail and hooves 
like horses. This frightened the children and they fled back to the room. They told their parents and were told off, so they went to bed all teary-eyed and promised never to solve riddles again on Saturday nights.

ERA II 240, 551/2 (3)

The location could also be some other place, as is seen in the story written down by Tõnu Wiedemann in 1892:

In the olden days of serfdom, during threshing. Serfs and ghosts posed riddles for one another. This went on for a good while. All of a sudden a red hand appeared through the ceiling. And a voice went: 'Riddle me, riddle me - what is this?' Everyone was too scared to even breathe.

H II 37, 677 (1) < Jõhvi Parish

The personified Devil or the aggressor (Kõiva 1996: 167) in horror stories such as these is usually a scary 'bloody hand' or a 'truly enormous bloody fist'; the colour red (also characteristic of demons) functions here as a symbol of fire (hell), suffering, and blood (Valk 1994: 120). A 'bloody knife' shares the same meaning. But the Devil also appears in the form of a 'big black finger'. The colour black, which symbolises the under-realm and the forces of darkness was seen as the usual colour of demons as early as the beginning of Christianity (ibid.). In some stories we can also see animal forms, such as 'a head of a blazing-red horse' or 'a bloody calf', which are also likely to indicate the Devil.

The educational aspect of the stories is revealed in their climax.

On New Year's Eve young boys and girls all gathered in one household. They poured molten lead for luck and had all kinds of fun. After all that, they finally covered the floor with straw, sat down, and started to pose riddles to one another. In the end two boys went outside. They saw a big yellow-faced old hag standing in the yard, with long teeth like those of a rake in her mouth. 'Riddle me, riddle me!' the old hag shouted through her teeth and disappeared. The boys ran back inside in terror and told the story to the others. After that the boys and girls didn't feel at all like riddling any more.

E 6249-6259 < Ambla, Tapa, Otto Hintzenberg, no date

In the past, when people wanted to pass the time or ward off sleep, they posed riddles for others to solve. Once upon a time there was a family that gathered in their house, posing riddles again. All of a sudden, the door of the house opened and a man appeared on the doorstep, hit his hand against his chest and said: 'Riddle me!' The master of the house happened to be holding a large silver brooch in his hand and used it to hit the man 
at the door. The door was shut right away, but they heard groaning in the porch. The groans finally stopped when the rooster started crowing. E 21772-21773 (9) < Karl August Sinka, Halliste Parish, 1895

The stories recorded in texts from the end of the nineteenth century tend to be more horror-like, but later texts from the second quarter of the twentieth century are more akin to anecdotes. The story written down by Mari Sarv in 1936 is rather humorous in tone.

In the olden times, when people were inside in the evening, solving riddles, Old Nick stuck its tongue through the door and said: 'Hey stupid, riddle me!' The child in the cradle then said: 'That is Old Nick's tongue.' Then it disappeared.

ERA II 142, 409/10 < Karksi Parish

In addition to mystical reasons, there are also some very pragmatic ones for banning riddles, as can be seen in the following text from Karksi Parish.

It is not allowed to solve riddles at night or you won't be able to fall asleep. H II 48, 330 (66) < Karksi Parish, Jaak Hünerson, 1894

The reason for banning riddles at night may be attributed to their stimulating nature because solving riddles provokes the mind, thus deterring sleep as described in the reports below.

Riddles were solved when making yarn, to ward off sleepiness.

RKM II 64, 406 (308) < Hargla Parish, Olga Jõgever, 1957

In the past riddles were told at night while working. During the long winter nights while sitting behind spinning wheels, to ward off sleepiness. RKM II 92, 74 < Kambja Parish, Anna Relli, 1959

It would be interesting to find out more about the usage links and meanings of reports related to the ban on riddles. But again, such comments would require explanatory context. At first, they seem to share similar traits with taboos and bans familiar from routine beliefs (e.g. no whistling indoors), the study of which could benefit from knowledge of belief-related backgrounds.

\section{CONCLUSION}

If riddles are considered through methods of text generation and figurativeness, they can be seen as an aesthetic phenomenon, but when analysing this, it is also important to take into account the context of riddles, not just their textual 
parameters. This will help clarify the more general functions and meanings of riddles. The enigmatic speech genre opens up the belief-related and entertaining relations of the belief (e.g. sending people who do not know the answer to the right place somewhere to get the answers), as 'icebreakers' in tense situations (e.g. celebrations of St. Martin's Day and St. Catherine's Day), as the creator and promoter of an erotic atmosphere. Riddling as a forbidden activity is expressed very strongly in a special type of fictional narratives (horror or warning stories) which were told to amplify the emotion related to the violation of rules (riddling without permission).

Therefore, in social contexts the function of riddles is opened up further (e.g. in syncretic relation with autumn-winter riddling calendar and wedding customs), featuring belief-related backgrounds, sacral and profane passing of time as well as economy - in certain cases, riddles were told to promote the household and work. Belief-related contexts were put in focus in this study, but these are far from being independent and different from other contexts - they combine with other, for instance, social, entertaining, aesthetic, and historic contexts.

\section{ACKNOWLEDGEMENTS}

This article is an English adaptation and expansion of the chapter of the doctoral thesis Eesti mõistatused kui pärimusliik muutuvas kultuurikontekstis (Estonian Riddles as a Folklore Genre in a Changing Cultural Context; see Voolaid 2011a). This research has been supported by the European Regional Development Fund (Centre of Excellence in Estonian Studies - CEES TK145) and is related to research project IUT 22-5 "Narrative and belief aspects of folklore studies" (Estonian Research Council). The author wishes to thank the anonymous reviewers for their valuable comments.

\section{NOTES}

1 EM 1324: A gipsy's pocket watch, a pig's oak, a frog's well, and a cat's apple? Head (sun), alder, spoon, and juniper berry; EM 1509 - Wethers of the valley, sheep of the woods? Wolves and bears; EM 1876: Feathered fox? Raven; EM 2165: Road slip, land reed, rooster of the forest, goat of the sea, a white-headed calf of the beach? A sledge, a harrow, a cuckoo, a fish, foam. See also Voolaid $2011 \mathrm{~b}$ on kenning-like riddle conundrums.

2 In Finnish hölmöläinen means 1. 'nitwit'; 2. 'fool, dumb person'; lä is a locative suffix, and himola < himo - 'passion, desire'. 


\section{ARCHIVAL SOURCES}

Manuscript files of the Estonian Folklore Archives at the Estonian Literary Museum: $\mathrm{H}=$ Folklore collection of Jakob Hurt (1860-1906)

$\mathrm{E}=$ Folklore collection of Matthias Johann Eisen (1880-1934)

E, StK = Folklore collection of Matthias Johann Eisen's grantees (1921-1927)

ERA $=$ Folklore collection of Estonian Folklore Archives (1927-1944)

$\mathrm{KKI}=$ Folklore collection of the Department of Folkloristics of the Institute of Language and Literature (1941-1984)

$\mathrm{RKM}=$ Folklore collection of the Department of Folkloristics at the Estonian Literary Museum (1945-1994)

\section{REFERENCES}

Abrahams, Roger D. 1968. Introductory Remarks to a Rhetorical Theory of Folklore. The Journal of American Folklore, Vol. 81, No. 320, pp. 143-158. http://dx.doi. org/10.2307/537664.

Alexander, Michael 1982 [1980]. Old English Riddles from the Exeter Book. Poetica, Vol. 11. London: Anvil Press Poetry.

ATU = Uther, Hans-Jörg 2004. The Types of International Folktales: A Classification and Bibliography. Part I: Animal Tales, Tales of Magic, Religious Tales, and Realistic Tales, with an Introduction. Folklore Fellows' Communications 284. Helsinki: Suomalainen Tiedeakatemia.

Durkheim, Émile 1915. The Elementary Forms of Religious Life. London: G. Allen \& Unwin. Available at https://archive.org/details/elementaryformso00durk/page/ n6, last accessed on 15 February 2019.

EE 1995 = Eesti entsüklopeedia . [Estonian Encyclopaedia.] Vol. 8, Rai-Sum. Tallinn: Eesti Entsüklopeedia.

EM 2001 = Eesti mõistatused. [Estonian Riddles.] Monumenta Estoniae Antiquae IV. Aenigmata Estonicae I. Comp. by Anne Hussar \& Arvo Krikmann \& Rein Saukas \& Piret Voolaid; edited by Arvo Krikmann \& Rein Saukas. Tartu: Eesti Keele Sihtasutus.

EM 2002 = Eesti mõistatused. [Estonian Riddles.] Monumenta Estoniae Antiquae IV. Aenigmata Estonicae II. Comp. by Anne Hussar \& Arvo Krikmann \& Rein Saukas \& Piret Voolaid; edited by Arvo Krikmann \& Rein Saukas. Tartu: Eesti Keele Sihtasutus.

Hamilton, Edith 1942. Mythology. New York: The New American Library. Available at https://archive.org/details/EdithHamiltonsMythology/, last accessed on 20 March 2019.

Hiiemäe, Mall 1994. Eesti rahvakalender VI. [Estonian Folk Calendar.] Tallinn: Eesti Raamat.

Huizinga, Johan 1949. Homo Ludens: A Study of the Play-Element in Culture. London \& Boston \& Henley: Routledge and Kegan Paul. Available at http://art.yale.edu/ file_columns/0000/1474/homo_ludens_johan_huizinga_routledge_1949_.pdf, last accessed on 15 February 2019. 
Kaivola-Bregenhøj, Annikki 1996. Riddles and Their Use. In: Galit Hasan-Rokem \& David Shulman (eds.) Untying the Knot: On Riddles and Other Enigmatic Modes. New York \& Oxford: Oxford University Press, pp. 10-36.

Kaivola-Bregenhøj, Annikki 2001. Riddles: Perspectives on the Use, Function and Change in a Folklore Genre. Studia Fennica Folkloristica 10. Helsinki: Finnish Literature Society. http://dx.doi.org/10.21435/sff.10.

Kõiva, Mare 1996. Siis astu aknalauale. [Then Step on the Window Sill.] In: Mare Kõiva (ed.) Mängult-päriselt. Tänapäeva folkloorist II. Tartu: Eesti Rahvaluule Arhiiv \& Eesti Keele Instituut, pp. 166-188. Available at http://www.folklore.ee/rl/pubte/ ee/cf/mjap/mare.html, last accessed on 14 February 2019.

Krikmann, Arvo 1997. Sissevaateid folkloori lühivormidesse I: Põhimõisteid, žanrisuhteid, üldprobleeme. [Insights into Short Forms of Folklore I: Basic Terms, Genre Relations, General Problems.] Tartu: Tartu Ülikooli Kirjastus. Available at http://www. folklore.ee/ kriku/PARINTRO/Parintro.pdf, last accessed on 15 February 2019.

Krikmann, Arvo 2000. Eesti mõistatuste kujunditest. [On the Figurativeness of Estonian Riddles.] Available at http://www.folklore.ee/ kriku/PARINTRO/troobid.htm, last accessed on 15 February 2019.

Krikmann, Arvo \& Krikmann, Jaak 2012. Eesti mõistatused. [Estonian Riddles: Database.] Web database. Available at http://www.folklore.ee/moistatused, last accessed on 14 February 2019.

Kuusi, Matti 1992. "Kenning”-jälkiä kalevalaisessa muinasepiikassa? [Traces of Kennings in Kalevala-Meter Epics.] In: Lauri Harvilahti (ed.) Metafora: Ikkuna kieleen, mieleen ja kulttuuriin. Helsinki: Suomalaisen Kirjallisuuden Seura, pp. 107-124.

Leisiö, Timo 2000. The Riddle Game of Visiting Hymylä Revisited: A Shamanic Point of View. In: Maria Vasenkari \& Pasi Enges \& Anna-Leena Siikala (eds.). Telling, Remembering, Interpreting, Guessing: A Festschrift for Prof. Annikki KaivolaBregenhøj on her 60th Birthday 1st February 1999. Joensuu: Suomen Kansantietouden Tutkijain Seura, pp. 272-286.

Lill, Anne 2004. Tragöödialeksikon: Teemad ja tegelased antiikkreeka teatris. [Lexicon of Tragedy: Themes and Characters at Ancient Greece Theatre.] Tartu: Tartu Ülikooli Kirjastus.

McDowell, John Holmes 1979. Children's Riddling. Bloomington \& London: Indiana University Press.

Oinas, Felix J. 1984. Mõista, mõista, mis see on. [Riddle Me, Riddle Me.] In: Felix J. Oinas (comp.) Vargamäe tõde ja õigus: Esseid = Truth and Justice of Vargamäe and Other Essays. Stockholm: Välis-Eesti \& EMP, pp. 162-173.

Rapp, Albert 1951. The Origins of Wit and Humor. New York: Dutton.

Sarv, Mari 2003. Lühivormide heakõlalisuse ehituslikest eeldustest. [Structural Prerequisites for the Euphony of Short Forms.] Uurimusi folkloori lühivormidest. Reetor 1. Tartu: Eesti Kirjandusmuuseum, pp. 145-188.

Saukas, Rein 2005a. Eesti mõistatuste allikalugu. [The Source History of Estonian Riddles.] Vol. I. Reetor 5. Tartu: Eesti Kirjandusmuuseumi folkloristika osakond \& Eesti Kultuuriloo ja Folkloristika Keskus.

Saukas, Rein 2005b. Eesti mõistatuste allikalugu. [The Source History of Estonian Riddles.] Vol. II. Reetor 6. Tartu: Eesti Kirjandusmuuseumi folkloristika osakond \& Eesti Kultuuriloo ja Folkloristika Keskus.

Saukas, Rein 2007. Eesti mõistatuste allikalugu. [The Source History of Estonian Riddles.] Vol. III. Reetor 7. Tartu: EKM Teaduskirjastus. 
Saukas, Rein 2009. Eesti mõistatuste allikalugu. [The Source History of Estonian Riddles.] Vol. IV. Reetor 8. Tartu: EKM Teaduskirjastus.

Senderovich, Savely 2005. The Riddle of the Riddle: A Study of the Folk Riddle's Figurative Nature. London \& New York: Kegan Paul.

Stefanova, Ana 2007. Riddles as a Community Psychological Phenomenon in Folklore: Myths, Fairytales, Personal Literature Art. Folklore: Electronic Journal of Folklore, Vol. 35, pp. 131-142. http://dx.doi.org/10.7592/FEJF2007.35.stefanova.

Taylor, Archer 1951. English Riddles from Oral Tradition. Berkeley \& Los Angeles: University of California Press.

Tedre, Ülo 1973. Eesti pulmad: Lühiülevaade muistsetest kosja- ja pulmakommetest. [Estonian Weddings: Short Overview of Old Estonian Wedding Traditions.] Tallinn: Eesti Raamat.

Tolkien, John Ronald Reuel 2006 [1937]. The Hobbit, or There and Back Again. London: Harper Collins Publishers.

Valk, Ülo 1994. Kurat Euroopa usundiloos: Sissejuhatus demonoloogiasse. [The Devil in European Religion: Introduction into Demonology.] Tallinn: Vikerkaar.

Viidalepp, Richard 2004. Eesti rahvajuttude laadist, funktsioonist ja jutustajatest. [The Style, Function, and Narrators of Estonian Folktales.] Sator 4. Tartu: EKM Teaduskirjastus. Available at http://www.folklore.ee/rl/pubte/ee/sator/sator4/, last accessed on 14 February 2019.

Virtanen, Leea 1966. Suomalais-virolainen arvoitussarja. [Finnish-Estonian Riddle Series.] Suomalaisen Kirjallisuuden Seuran toimituksia 282. Helsinki: Suomalaisen Kirjallisuuden Seura.

Virtanen, Leea 1977. On the Function of Riddles. In: Leea Virtanen \& Annikki KaivolaBregenhøj \& Aarre Nyman (eds.) Arvoitukset: Finnish Riddles. Suomalaisen Kirjallisuuden Seuran toimituksia 330. Helsinki: Suomalaisen Kirjallisuuden Seura, pp. 77-90.

Vladykina, Tatiana 1998. Udmurtskii fol'klor: Problemy zhanrovoi evoliutsii i sistematiki. [Udmurt Folklore: Problems of Genre Evolution and Systematics.] Izhevsk: Udmurtskii Institut istorii, iazyka i literatury UrO RAN.

Voolaid, Piret 2005. Eesti mõistatuste perifeerne aines: Elektroonilised andmebaasid internetis. [The Periphery of Estonian Riddles: Digital Online Databases.] Diss. (Master's Thesis). Tartu: Tartu Ülikool. Available at http://dspace.utlib.ee/dspace/ bitstream/10062/1216/5/voolaid.pdf, last accessed on 15 February 2019.

Voolaid, Piret 2011a. Eesti mõistatused kui pärimusliik muutuvas kultuurikontekstis. [Estonian Riddles as a Folklore Genre in a Changing Cultural Context.] Dissertationes folkloristicae Universitatis Tartuensis 16. Tartu: Tartu Ülikooli Kirjastus. Available at http://dspace.ut.ee/bitstream/handle/10062/17528/voolaid_ piret.pdf, last accessed on 15 February 2019.

Voolaid, Piret 2011b. Why is the Floor Squeaking? Because the Wiser One Gives In: On Relations Between Estonian Conundrums and Paremiology. 4th Interdisciplinary Colloquium on Proverbs: 7th to 14th November 2010: 4 Coloquio Interdisciplinar sobre Proverbios: Actas ICP10 Proceedings, pp. 245-257.

Voolaid, Piret 2017. Mõistatused ja mõistatamine Virumaal. [Guessing and Riddles in Virumaa.] Mäetagused, Vol. 66, pp. 115-138. https//doi.org/10.7592/MT2017.66. voolaid.

Williamson, Craig 1977. The Old English Riddles of the Exeter Book. Chapel Hill: The University of North Carolina Press. 


\title{
REPRESENTING SEXUALITY THROUGH FOLKLORE: EROTIC FOLKTALES AND ONLINE JOKES AS 'MIRRORS' OF GENDER HIERARCHIES
}

\author{
Aleksandar Takovski \\ Institute of Social Sciences and Humanities, Skopje, Macedonia \\ e-mail: aleksandar.takovski@isshs.edu.mk
}

\begin{abstract}
Gender roles, relations, and structures are aspects of human sexuality that are (re)constructed, negotiated, and even contested through a variety of discourses, including folklore. Erotic tales and sexual jokes are folk genres in which human sexuality is most explicitly presented. In this respect, the two key questions this study seeks to answer are: what kind of sexuality (gender roles, relations, and structures) is constructed through these genres and what inferences may be made about the society underpinning the discourse thus produced. To accomplish the ends, the study uses material collected from the Republic of Macedonia, organized in two data corpuses: erotic folktales and online sexual jokes. The content of the data is analyzed in order to identify the most reoccurring themes, gender roles, and relations constructed vis-à-vis the dominant motif in these narratives - the sexual intercourse, and thus to be able to describe the discourse on sexuality constructed by and through these genres, comment upon its social implications, and suggest way(s) of using it as a tool to counteract gender inequalities.
\end{abstract}

Keywords: erotic tales, folklore, function, gender differences, Macedonian folklore, online sexual jokes, representation, sexuality

\section{INTRODUCTION}

Human sexuality is a complex phenomenon related to and affecting multiple aspects of human social life, such as sexual intercourse, orientation and relationships, gender identities and relations, reproduction, family, marriage, birth control, etc. It is a phenomenon that actively constructs social identities, relations, structures, and practices along with the underlying views, beliefs, and values. At the same time, and even more importantly, it is a phenomenon that is constructed by various centers of power, such as the Monarch, the Church, and the State, who have recognized the role and the power of sexuality 
(Foucault 1978 [1976]) and have accordingly constructed various discourses (religious, political, economic, educational, cultural, artistic, etc.) in order to control sexuality and legitimize different political and economic ends.

Folklore, in this context, may not be the key instrument used to define and control sexuality, yet it is naive to believe that it is a mirror that reflects society either in its totality or in its consensual objectivity. The mere fact that folklore in the past was collected, selectively organized, presented, and used mostly by male collectors, ethnographers, and researchers, raises serious doubts regarding the potential gender perspectivization and gender-biased representation of sexuality through folklore. Folklore in this respect is only a fragmentary view of society, whereas erotic folklore in particular represents only certain types of sexual, and at the same time gender and social identities and relations, while foregrounding and/or omitting others. Social power structuration underlies such representations of sexuality which serve, I argue, to perpetuate male dominance, gender hierarchies, and specifically male views of society and sexuality.

In this respect, the two main research questions this study seeks to answer are: a) what kind of sexuality (gender identities, roles, and relations) is constructed through erotic folklore, and b) what inferences can be drawn about the society and its gender structures and hierarchies based on sexual discourse so produced.

To answer these questions, the study will first provide a theoretical overview of research ideas and findings related to three questions: a) What social functions of folklore can be related to sexuality? b) What kind of sexuality is constructed through erotic folktales on the one hand and sexual jokes on the other? c) What are the underpinning motives and purposes of such a construction? In the two sections following the literature review, I will present and analyze the data gathered and discuss the findings in relation to current literature. For the purposes of the study I used two data corpuses. The first consists of the English translations of 59 folk erotic tales collected by Macedonian folklorist Kiril Penushliski, translated by Slavists Gjorgji Mitrevski and Christina Kramer, ${ }^{1}$ and the second is comprised of 270 online erotic jokes collected from Macedonian most popular site for entertainment, www.vicoteka.mk, which contains the largest joke base in Macedonia. The contents of the tales and jokes were analyzed in order to first identify the most commonly occurring themes related to the key motif - sexual intercourse, and to be able to identify and categorize the sexual identities, roles, and relations of the protagonists in an attempt to (re) construct/exemplify the discourse on sexuality constructed through these texts.

The reason for choosing these two particular genres is twofold. Firstly, examples of sexual jokes from the period the erotic folktales were collected are unavailable. This could either point to the low level of popularity or even non- 
existence of the genre prior to the twentieth century, or to the lack of collected and preserved material. On the other hand, while the erotic folktale is a different genre than the joke, the time of their popularity and intensive circulation in society - namely before the twentieth century - gives and indispensable opportunity to gain an insight into the sexual mores and attitudes in a society much different than today's and thus to be able to draw some enlightening parallels and/or comparisons.

Finally, studying erotic folklore by means of these two particular genres seems to be a great challenge for understanding the social impact of the genres. In the absence of a detailed, documented account of the context of occurrence of erotic folktales (who, to whom, where, when, why, how), although there is a tacit agreement among researchers that such tales were usually told by men to a mixed, but mostly grown-up audience, it is difficult to draw any definite conclusions about the social functions of the tales, based on their textual analysis. The same may be said about online jokes that are usually accompanied by signs of appreciation (likes), yet no verbal or non-verbal reaction indicative of agreement, disagreement, protest, rejection, and the like. However, certain assumptions about the underpinning social hierarchies and dominant views and values as well as the social impact of erotic folklore may be made indirectly, by contextualizing research on folklore functions within the topic of sexuality. Therefore, I shall start the theoretical section with a very brief discussion on the functions of folklore in society and see how these relate to the genres concerned in order to shed light on the nature of erotic folklore as a vehicle of constructing, disseminating, and pre-treating sexual roles and relations.

\section{FOLKLORE, EROTIC TALES, AND SEXUAL JOKES}

\section{Functions of folklore and its relation to sexuality}

Developed under the influence of anthropology (Malinowski 1926; RadcliffeBrown 1952), one of the first to introduce the functional paradigm in the study of folklore was William Bascom (1954), who differentiated four functions of folklore. According to Bascom, folklore is a useful tool to educate children especially in non-literate societies, and to inculcate the customs and ethical standards to the young, while for the grownups it is a form of escapism, or in Bascom's own words, "folklore reveals man's frustrations and attempts to escape in fantasy from repressions imposed upon him by society, whether these repressions be sexual or otherwise" (ibid.: 343), which allows him to express thoughts or feelings that are not appropriate in everyday society. In addition, folklore also 
serves as an instrument that maintains "conformity to the accepted patterns of behavior" (ibid.: 346) through the application of social pressure and exercising of social control against individuals who attempt to deviate from social conventions. When this happens, Bascom argues, "a song of allusion, a proverb, a riddle or a folktale may be used to express disapproval" (ibid.). Lastly, folklore helps validate culture (and its social institutions, beliefs, and attitudes) in times when dissatisfaction with or skepticism towards an accepted pattern is expressed. Then, Bascom explains, usually a myth, a legend, an explanatory tale or a proverb is deployed to validate the pattern, thus settling down the dissatisfaction (ibid.: 344$){ }^{2}$

The transgressive nature of folklore has also been pointed out by Alan Dundes, for whom folklore "provides a socially sanctioned outlet for the expression of what cannot be articulated in more usual ways. It is precisely in jokes, folktales, folksongs, proverbs, children's games, gestures, etc. that anxieties can be vented" (2007: 275). Thus, "folklore can serve as a vehicle which requires an individual to do what he may not be permitted to do in everyday reality (e.g., in courtship games, complete strangers may kiss, in games of chase, acts of physical aggression are mandatory)" (Dundes 1966), thereby relieving the individual from assuming the responsibility (and guilt) for his or her actions (Dundes 2007: 60).

In terms of sexuality, it is easily conceivable how folklore can instruct younger generations into the proper, usually heteronormatizing discourse by offering them informative and didactic stories, inculcating them with acceptable norms of sexual behavior, or how it can offer grown-ups a world of fantasies inadmissible in reality, where they are not afraid to openly think and talk about sex, while at the same time using this folkloristic discourse for normative purposes to warn the adults who may potentially transgress the accepted norms.

While the assumption that folklore is a safe, unsanctioned outlet for the expression of culturally suppressed contents, forbidden desires, impulses, and fantasies is certainly true, doing so for the mere enjoyment or for the temporary sensation of liberation does not exhaust the social potential of folklore. If folklore is a symbolic reaction and reproduction of a culture and its sexual mores in this case, then the question is not only what kind of sexuality is reproduced through folklore, but what the end of it could be. Is it to perpetuate or challenge the socially dominant discourses on sexuality? To answer these questions, the next section will discuss erotic folklore focusing on the nature and role of the discourse on sexuality produced through erotic tales and sexual jokes. 


\section{Erotic folklore}

Although erotic folk material is available in many collections, starting from the earliest ones, such as Afanasyev's Russian Secret Tales (1966 [1872]), Krauss' Kryptadia (1883) and Antropophyteia (1904-1913), and many studies on erotic folklore have been produced, very few scholars tackle the question of the nature and role of sexual discourse produced through erotic folklore. Even the most popular name, when it comes to the study of sexual folklore, Gershon Legman, offers no committed socio-functional analysis or comprehensive understanding of sexual folklore. For Legman sexual folklore is a mechanism through which people "are projecting the endemic sexual fears, and problems, and defeats of their culture ... on certain standard comedy figures and situations, such as cuckoldry, seduction, impotence, homosexuality, castration, and disease, which are obviously not humorous at all" (Legman 1962: 201). All folklore, including humor, is an anxiety-releasing tool by which a joke teller sloughs off his fears by exposing the listener to the same fears and anxieties. In his opus magnum, Rationale of the Dirty Joke: An Analysis of Sexual Humor (1968), Legman provides a thorough taxonomy of sexual and scatological jokelore, but unfortunately falls short in producing a comprehensive and convincing functional and contextual analysis of the material. Instead, it seems that Legman is only highlighting the conceptual problems related to Freud's model, which he sets as his analytical framework. ${ }^{3}$ On the one hand, the model itself is psychological, rather than social, focusing on the anxiety-releasing function of humor, while on the other hand, Legman fails to accommodate the possibility that sexual humor may have other motives and ends beyond the release of anxiety and aggressive imposition of fear, such as assertion of superiority, imposing norms, creating interest, lubricating communication or merely having fun.

Studies of Slavic and South-Slavic erotic folklore are faced with similar challenges. While there are plenty of collections of erotic folklore (Terseglav 1981; Mrduljaš 1980; Krstanović 1984; Karadžić 1979; Vujkov 1990), and many scholars have studied different aspects of the material as various as the metaphoric aspects of erotic discourse in oral poetry (Pandurevic 2016), the function of laughter and carnivalization in popular erotic poetry (Karanović \& Jokić 2009), erotic connotations of cultural plants (Sikimić 2013), substitution of erotic with non-erotic language (Gura 2005), and manifestation of normal (women's and men's physical beauty, puberty, strength of libido, appropriate time for intercourse, etc.) versus abnormal (incest, manage a trois, gerontophilia, pedophilia, sodomy, etc.) sexuality (Kostic 1978), the question of sexual discourse constructed through folklore and its relation to society remains unanswered. 
The majority of the studies in the edited volume titled Erotsko $u$ folkloru Slovena: zbornik radova (Erotic in the Slavic Folklore) (2000) are dedicated to the tradition of collecting, organizing, and differentiating between genres, without revealing much or anything about the sexual roles, identities, and relations produced through erotic folklore, and their relations to society. Thus, these studies discuss a variety of folk erotic genres and aspects, such as the possibility to define (erotic) tongue twisters by the criteria of erotic elements present (Sikimić \& Otasević 2000), the distribution of themes of sexual humor per age groups (Miceva 2000), the recognition of erotic/eroticized proverbs (Grzybek 2000), self-distancing and norm-breaking principles underlying erotic jokes (Stanoev 2000), and other topics.

Although each study has a merit in its own right, it seems that only Ajdačić's study provides some insight into the gender-based hierarchies constructed through folklore. Studying the construction of the comic in the erotic folk tales, Ajdačić (2000) outlines three narrative instruments that underlie it: language, situation, and characters. Some of the linguistic forms and structures frequently deployed include: verbs that denote forceful movement, double language, and use of allegories and non-erotic expressions for erotic concepts and body parts, among others. In the analysis, Ajdačić notes that experienced, knowledgeable characters, usually males, use figurative language to lure inexperienced characters, usually females, into the act of love, thus highlighting one of the basic dichotomies present in the erotic narrative, the one between knowledge and lack of knowledge, between experience and inexperience. An interesting observation is that females are most often victims to experienced males, while males are victims to female adultery, an observation that is also valid for the material under consideration. In terms of functions of folklore, Ajdačić suggests that erotic folklore can educate the inexperienced by giving tips about sex life related to physiology, sexual morality, and pleasure, while at the same time criticizing lack of moderation, excess of lust or manifestation of other sex-related sins. Additionally, erotic folklore may be considered as a form of symbolic protest and revenge against the social hierarchy and injustice, especially manifested in the narratives where a poor male character lures a rich man's wife into a sexual intercourse. Finally, a good observation by Ajdačić is that women are portrayed negatively in the erotic folklore due to the fact that "tales depict a male's image of the world, both of the teller and the collector" (2000: 501).

Ajdačić's observation that folk tales are misogynist pieces of folk expression is also confirmed by Lövkrona's study (1998) of the construction of gender, gender differences, and hierarchies in the erotic narratives produced in premodern Sweden, in which the author argues that the politics of erotic folklore served to legitimize and sustain male power structures. Lövkrona's analysis of the theme, 
plot structure, and voice constructed in the narratives, intended to uncover power relations between the actors in the story, but also the gender roles, relations, and hierarchies in society, reveals two different types of masculinities and femininities involved. Positive masculinity is represented by a young unmarried man, a man who is potent, smart, and always ready to seduce, while positive femininity is manifested by the young, unmarried, sexually innocent, but willing woman. The incarnation of the negative masculinity, according to Lövkrona, is a male character who fails to satisfy or seduce a woman, as well as a man who is impotent and sexually inexperienced. Negative femininity, on the other hand, is represented by women who are wanton, lewd, sexually insatiable, and who take sexual initiative: women who clearly represent a threat to masculinity.

Related to this last type of femininity is Lövkrona's argumentation that although men are those who provide models for the interpretation of reality in patriarchal societies, women have accepted these models, but have additionally created their own, alternative meanings, sort of "oppositional reading" (Hall 1980) of the narrative, with an embedded "hidden transcript" (Scott 1990). This is made possible through the identification with the position of negative femininity, which is also a position of independence and resistance, and insubordination to the male, patriarchal expectations of women. Identifying with females who were lewd and sexually active but strong and independent at the same time, Lövkrona argues, empowered women by offering them the power and scope for agency. The symbolic nature of this subversive strategy notwithstanding, it is hard to believe that the possibility to identify with independent female characters who pose a threat to masculinity and thus ridicule males' hierarchies, has really affected the female members of the folk audience beyond the momentary sigh of relief.

Finally, Macedonian erotic folklore is preserved in several collections, such as those by Cepenkov (2007) Penushliski (1989), Velichkovski (1989), Smilevski (1993), Risteski (1994), and others, and has been studied by a few scholars, most recently Martinoska (2007) and Pilichkova (2009). In a fashion similar to Ajdačić, Pilichkova (2009) highlights the role of humor as a basic aesthetic building block of the erotic folklore. Although not going into a fully-fledged humor analysis of the material, Pilichkova offers a thematic classification of the material, listing several categories, among which are: anticlerical tales ridiculing the sexual advancements of dishonest priests and hodjas ${ }^{4}$ being punished for their misbehavior, instrumental, clever substitution of erotic with non-erotic language, ambiguous sexual expressions, sex used as an instrument of vengeance (e.g. to the infidel priest), a jealous husband being outsmarted by a woman through a sexual intercourse (sex as educational tool), adulterous women, and, identically to Ajdačić, the experienced/inexperienced dichotomy, 
where innocent girls fall prey to experienced men, and naïve husbands are victims of adulterous wives. Although not engaging in a social analysis of the erotic folktale, Pilichkova concludes that erotic folklore is used to ridicule the imperfections of certain individuals or professions.

\section{Sexual jokes}

While many sexual jokes tend to perpetuate socially constructed stereotypes of certain groups of people, as is the case with the physically attractive blondes, or oversexed, adulterous French women (Davies 2011), there is also a significant corpus of jokes that challenge patriarchal hierarchies and criticize dominant constructions of femininity as pointed out by Lövkrona (1998). Such line of argumentation is a significant step forward from the previous ideas about the nature of sexual humor dominated by the Freudian concept of sexual jokes. According to Freud (1960 [1905]), jokes allow the expression of forbidden, suppressed, and unconscious aggressive and sexual impulses and desires arising from the id by circumventing the censorship of the superego through a clever joke technique, thus allowing gratification of the libidinal impulses, and enabling a discharge of superfluous nervous energy through laughter. Thus, jokes allow people to experience for a moment the illicit pleasure derived from releasing some of our primitive sexual and aggressive impulses. This presupposes that people who suppress these impulses most would feel the greatest pleasure arising from the release of nervous energy, and enjoy the sexual jokes most - an assumption that empirical research has falsified on many occasions (Levine \& Redlich 1955; Kline 1977; Ruch \& Köhler 1998). The relief function of jokes notwithstanding, more recent studies of feminist humor have elaborated on the manners in which such humor challenges traditional views of gender by targeting men, resists dominant constructions of femininity, as well as opposes gender inequalities and hegemonies in a patriarchal society with an aspiration to reform it (Crawford 1995, 2003; Franzini 1996). In a study on lesbian humor, Bing and Heller (2003) show how sexual humor can challenge dominant culture and its definitions and presuppositions about lesbianism. The authors demonstrate how lesbian jokes help lesbians construct and negotiate (homo)sexual identities as an empowering mechanism which through transformation, resistance, and subversion challenges dominant views and presuppositions. In a more recent study conducted among Bahrein women, Reichenbach (2015) shows how these women who are expected to be respectful of the societal images (gender ideals) and expectations of females as self-controlled, restraining, obedient housewives not permitted to laugh publicly, use humor to resist, challenge, and criticize 
gender identities and patriarchal hierarchies. It is through humor that these women achieved liberation from the pressures and constraints of the patriarchal society and coped with its gender inequalities and absurdity.

While it is certain that sexual/feminist humor can definitely challenge gender hierarchies, it is hard to tell whether sexual/feminist jokes may bring any social change, especially in societies where such narratives are being circulated in the safe zone of the closest relatives and friends (e.g. Bahrein). On the other hand, the public exposure of such material in more liberal, democratic societies may not only help social groups to more freely communicate their sexual identities but, by drawing the attention of the audience, it may also attract sympathy and even support. This, however, is only possible as a result of the interplay of several socio-political practices, public joking being just one of them.

\section{DATA AND METHODOLOGY}

Given the absence of contextual data on the material under investigation (Macedonian erotic folktales and erotic online jokes), examination of the erotic folklore potential to resist or even challenge gender-biased presuppositions and hierarchies in a communicative context is almost an impossible mission. However, a qualitative textual analysis of the material can construct a comprehensive image of the discourses of sexuality, upon which to draw inferences and provide plausible explanations of the gender relations, structures, and hierarchies embedded in and represented by these discourses.

To accomplish these ends, two data corpuses were used: the English translations of 59 folk erotic tales collected by Macedonian folklorist Kiril Penushliski, ${ }^{5}$ and 270 online erotic jokes, posted in the period from 26 September 2006 to 19 February 2018 in the erotic jokes section of the site vicoteka.mk, Macedonian most popular site for entertainment, containing the largest joke base in Macedonia. ${ }^{6}$ Using the data, the analysis seeks to identify: a) the most common themes present in the material, and b) the most common gender roles and relations vis-à-vis the dominant motive of sexual intercourse.

The process of identification of the main themes was relatively easy, given that some of the titles of the tales and jokes either directly revealed the subject matter of the narrative, as in "A wife can't be guarded", which unambiguously set the expectation of a story about an adulterous wife, or the title pointed to the main characters around which the theme of sexuality was developed, as is the case with the tale titled "The young man, the lady, and the servant". The text structure of the title hints that the plot evolves between a young man, who is either inexperienced or cunning, and a rich (either experienced or naïve) 
lady. The classification of the themes of the jokes was based either on the title (e.g. "The lover") or the punch line that revealed the key topic. The procedures of identifying the main themes, rather than their applications, were doublechecked by a colleague, and provided almost identical results, at times only in a different wording, for example, "unfaithful wife" instead of "adulterous".

\section{Erotic folktales}

The analysis of the folktale narratives reveals that the most frequent themes of the narratives in the order of their frequency (from high to low as shown in the brackets) are: a) sex as an end in itself $(n=16)$; b) sex as a tool of punishment $(n=14)$; c) other (29): male's oversized genitalia $(n=3)$, sex as a tool of juvenilization of older women $(n=2)$, impotence of old men $(n=2)$, sex as an instrument of material gain $(n=2)$, women's excesses of sexual desire $(n=2)$.

Regarding the most dominant motif of staging a sexual intercourse motivated by desire, in most of the tales bearing this motif it is men who are the initiators or the plotters of the act $(n=10)$. In these tales, men are most often presented as young, confident and potent seducers, who succeed in luring young and inexperienced women into the act of lovemaking by a witty design accomplished either through language or a cunning plan. Thus, in the tales titled "The grain gatherer" and “The priest's daughter who didn't want to get married”, the unwilling and unyielding young girls are lured into sexual intercourse by clever young men who use non-sexual language (grain gatherer, scratcher) for sexual body parts, most often for male genitalia (penis), to trick the inexperienced girls into having sex with them. The usual victims of such kind of language censorship, intended to disguise the true nature of the intentions, are peasant girls, priests' daughters, kings' daughters or even the queen herself. In the tale "The king's widow and the clever servant", the queen forbids the use of obscene language, but is seduced by a young peasant who substitutes all such expressions with the ones referring to elements of nature, such as heavenly fruits (tits), meadow (pubic area), spring (vagina), horse (penis), and saddle bags (testicles). Another strategy, in addition to language, deployed by men intending to trick women into sexual intercourse is to present sex as a solution to a grave, even fatal problem like death or the plague. Thus, in the tale "He spoke with the lord", the sister-in-law agrees to have sex with her brother-in-law as the latter pretends to be on his deathbed. Using the situation and his sister-in-law's empathy, but also her naiveté, he convinces her to have sex with him by presenting the act as God's will that will help him cure. The deployment of the same 'sex as cure' strategy occurs with a much lower frequency in narratives where women are presented in the capacity of initiators of sexual intercourse $(n=4)$, 
as in "Oh mercy I am dying for grapes", or "The cornel cherry salesman". What seems intriguing in this respect is that women are never, or at least not in the present corpus, presented as using language as an instrument of seduction. Instead, women use language as a strategic tool to cover for the infidelity, as in "Feminine wiliness", where the unfaithful wife makes up a whole story to accomplish the end.

The second most frequent motif is that of female's infidelity, which, against any expectations to be criticized and condemned, is very much acceptable since females' unfaithfulness is represented as a consequence of, and often a revenge for, the husbands' mistreatment, misbehavior, and adultery. Often women are pushed into committing adultery as a result of their husband's excess of confidence or jealous overprotection, manifested in forbidding the wife to socialize or even to leave the house. In many of the narratives bearing this motif, the husband is a priest, a hodja or a rich man, which adds a tone of social criticism to the class of high-status men, presenting them as an incarnation of the will for power and complete control. In three of the tales, the wife's infidelity is a result of the husband's verbal insults, in regard to which the 'crooked cunt' motif is the most frequent one. In these narratives, the husband makes fun of the wife's allegedly deformed genitalia (crooked cunt), so she seeks solution for the problem through a sexual intercourse with another man, usually a craftsman with the alleged skill of straightening vaginas. Finally, the wife's adultery is also a counter-reaction to the husband's infidelity. As a leitmotif, spousal infidelity is intriguing in two aspects. First, female's infidelity is carried out openly; the women who have sex outside marriage admit having it as a retribution, intended as a punishment for their husband's adultery. Differently than this, the cheated husbands actually trick their own unfaithful wives into believing that they (the wives) have sex with another man, while they actually have sex with their own husbands disguised as other men. Thus, men in these narratives change their appearance, disguise themselves as desired lovers, not only to get back at their unfaithful wives, but to also teach the adulterous wives a lesson, while at the same time to remain faithful, and unlike women, in their retribution, they remain sinless.

Another interesting motif present in the narratives is the use of sex as a medium of competition and material gain, as in the tale titled "The young man, the lady, and the servant", in which a young man's sexual prowess and trickery brings him a great deal of material gain (land, cattle, money) offered by the lady as a challenge to test his sexual potency and will. Other motifs present in the narratives once or twice include oversized male genitalia, old men's sexual impotence and sexual nostalgia, old women's desire to feel the thrill 
of physical love again, a man being scared of his wife's excess of sexual desire which is tamed by a trick, and physical punishment for the husband's infidelity.

\section{Jokes}

Although classifying a corpus of 275 jokes is both a menial and impossible task, given the variety of themes present as well as the subjectivity of the coder, some tentative categories may be defined, based on the aspect of sexual intercourse that is foregrounded (also functioning as a base for the punch line), and on the identity and relationship between the key protagonists.

\section{Women's infidelity, promiscuity, and sex urge}

One of the most reoccurring motifs in the jokes analyzed is that of females' sexual agency, manifested through spousal infidelity $(n=29)$, promiscuity $(n=27)$, and sex urge $(n=14)$. Some of the jokes manifesting female script simply illustrate the act:

Two friends are talking.

"Do you tell your husband each time you have an orgasm?"

"No way, he specifically told me not to disturb him while he is at work."

Other jokes carry more moralistic overtones by setting the husband as part of the narrative, in which he is usually presented as a naïve victim being mocked either by his wife or the lover:

A worker calls the office, explaining that he does not feel well and will not come to work. The boss says:

"When I feel down, I get on my wife, and after an hour I am as good as new, coming to work fresh as mountain dew."

After an hour the worker comes in. And the boss asks him how he is satisfied with the tip. The worker says:

"You are right, boss, the tip works miracles, especially with your wife beneath."

The second most frequent sexual behavior assigned to women in jokes is that of promiscuity $(n=15)$ :

After a great night, the guy asks the girl how many partners she has had before him. She is angry but starts to count. After three hours, the guy says: "I am sorry to have asked you this, I shouldn't have." 
She quickly replies:

"Oh, shut up, I am still counting."

or,

A woman complains to the doctor that she is hard to satisfy. The doctor recommends her to try it with two partners, to which she replies that she has already tried it. Then the doctor recommends she tries with five or even ten men, to which she replies she has done it already. The surprised doctor says:

"You are a medical phenomenon, my dear," and the woman replies:

"Exactly, my doctor, a phenomenon! Not a whore like everyone else thinks."

Very often promiscuous behavior is assigned to stereotypical professions, such as secretaries, nurses, and the demographic group of blondes $(n=12)$, while the jokes in which money is the motivation or the purpose of the intercourse very often include women as beneficiaries of material gain, although they are usually tricked and often humiliated by men $(n=9)$. Unlike erotic folktales, jokes do present women as openly talking about sexual fantasies and desires:

An American, a French, and a Macedonian female student were talking about what each of them wanted to be.

The American: "I want to be an oil field, so they would drill me...drill me."

The French: "I want to be an ice cream, so they would lick me...lick me."

The Macedonian: "I want to be a Faculty of Electric Engineering so they would finish with me in seven years."

\section{Men's lack of potency, interest, and underperformance}

As compared to similar representations involving male characters, there are a few differences. While men are also represented as unfaithful and promiscuous, although to a noticeably lesser extent, there is no male profession typically related to excessive sexual activity, nor is there a narrative in which males are lured into having sex for money, and, above all, there are no jokes in which men freely express their sexual fantasies. Moreover, the most frequent capacity men are represented in $(n=21)$ is the lack of sexual potency, interest, self-confidence, often underperforming - all types of behavior frequently being made fun of. The two following jokes illustrate some of the arguments:

When having sex, the wife tells her husband that he is like a mobile phone. Hearing this, the husband asks: 
"Is it because I vibrate well and make you excited?"

"No, it is because you lose the signal in the tunnel," the wife replies.

Two neighbors are talking. One of them says:

"Me and my husband, we have Olympic sex."

"Good for you, this means you have great sex," says the other.

"No, it means we have it every four years."

There is an obvious reason for ridiculing males' sexual underachievement, and this clearly emphasizes the social expectation of men to be sexually potent. The assumption that jokes favor males' views, attitudes, and even anxieties typical of patriarchal societies can also be inferred from jokes on the topic of men's unfaithfulness $(n=7)$. What is peculiar about these jokes is the focus on the act of adultery itself, rather than on the perception or even involvement of the cheated wife. In these narratives, the wife is frequently only implied, talked about, and even if she physically witnesses the act of adultery she is voiceless; as such she cannot evoke the sympathy of the audience as an innocent victim, as is the case with female adultery discovered by men. The following examples illustrate some of these arguments.

"Do you look into your wife's eyes while having sex?"

"I did once."

"How was it?"

"A disaster, it happened when she was walking into the bedroom."

"My father is a real coward," says a first-grader to another, and adds, "Each time mom is not at home, he is afraid to sleep alone and goes to the neighbor."

The second example is interesting from two aspects. First, it constructs male infidelity though a third-person narration, in this case a male child. By creating a narrative distance between the narrator (boy) and the action presented (father's adultery), it also potentially creates a moral distance, or at least it mitigates the potential effect - scorn by the audience. On the other hand, there is no example in which a little girl reveals a parent's sexual misconduct.

\section{Homosexuality}

Another notable difference between male and female characters in terms of their representation in sexual jokes is related to the issues of homosexuality and transsexuality - two aspects not found in erotic folktales. What is notable here is the manner in which male homosexuality $(n=9)$ is presented as a laughing 
stock, a completely innocent, non-threatening behavior, sort of de-masculinized phenomenon. The focal point of jokes on male homosexuals is their craving for anal sex as shown in the following two jokes:

A gay hadn't had sex for a while. After checking that there was no phallicshaped vegetable in the fridge, he went to the butcher's and ordered the biggest sausage. The butcher started chopping it into slices. Seeing this the gay shouted: "Hold on, honey, with that chopping. What do I look like to you, a jukebox?"

Two gays were crossing a river when one said: "I think that a fish just came up my anus." The other replied: "Keep going, is not a fish."

Unlike this mild ridicule of male's homosexual habits, female homosexuality is either defined vis-a-vis male as in "What do two lesbians sing after sex? All is the same save he is not around" or in gross manners as in "Why did the lesbian version of Cinderella die? During sex, her vibrator turned into a pumpkin”.

Finally, another significant difference related to transsexuality is that in all the three jokes on the issue of transgender / changed gender, it is a man who has become a woman, and thus it is a man who has sex with another man, thus becoming the butt of the joke, but it is never the other way round, a woman turning into a man having sex with a woman.

\section{Younger and older generations}

Other joke categories indicative of gender differences are: jokes about young generations who are either sexually more mature or have different sexual mores and ideas that usually shock the parents $(n=8)$, jokes about children who are knowledgeable about sex $(n=5)$, and jokes about older generations who lament over the loss of their sexual aptness or capitalize on an opportunity offered $(\mathrm{n}=10)$.

The most frequent parent-child relationship in the first category is that between a mother and daughter who, instead of learning something new about sex or proper sexual conduct, surprises the mother with an unexpected line of thought as demonstrated in the following joke:

A mother is teaching her daughter:

"In the moment of temptation, ask yourself whether an hour of pleasure is worth living a life of shame."

"Mom! You should tell me how you managed to make the pleasure last for an hour." 
While the usual pair in these educational jokes, in which sexual knowledge is intended to be passed from one generation to the other, is mother-daughter (female-female), the typical pair in the jokes in which the child demonstrates sexual awareness and knowledge untypical of the age is usually that of a father or a teacher and always a male child. Intriguingly, on the other side of the age spectrum, the old age, in many of the jokes it is mostly old women who are represented as lamenting over lost sexual powers or are eager to seize any opportunity that presents itself, even if it is presented as a punishment or a threat as in the following example:

A granny was flying on a plane where there were terrorists who demanded that each passenger should undress from the waist up. The granny asked: "Does everyone have to do this?"

"Yes," answered the terrorists, who then demanded that everyone undresses from the waist down so the terrorists would fuck them. Then a blonde asked:

"Do we all have to do that?" to which the granny replied:

"Shut up and do as you are told."

\section{Incongruous representation of sex}

Finally, the most numerous category of jokes is comprised of those that present and highlight an incongruous, and thus humorous, aspect of sexual intercourse, or an implication of it.

A man and a woman were making love. The woman got very excited and started shouting: "Tell me something dirty!" To which the man said: "Kitchen, bathroom, bedroom..."

Often there is a misinterpretation, a pun or a witty comment involved:

A man and a woman were making love, and the man says: "A bit down, now a bit up, ...wait, wait, give it to the right, now move a bit to the left..." To what the woman asks: "Sorry, my dear, do you plan to fuck me or park me?"

There are plenty of other themes that can be recognized in this large category, but with the focus on the incongruous perception and/or presentation of the sexual act, these jokes reveal little, if anything, about gender roles and relations. 


\section{DISCUSSION}

Although it is difficult to ascribe a definite educational value (Bascom 1954; Ajdačić 2000) to the folktales presented, especially in light of the absence of contextual data, they do confirm many of the current research findings discussed earlier. First, the majority of the tales highlight the existence of the experienceinexperience dichotomy precisely as discussed by Ajdačić (2000) and Pilichkova (2009) - a dichotomy in which an experienced, usually young man seduces an inexperienced woman by the use of figurative, goal-oriented language. Making these two characters the bearers of the leitmotif additionally corroborates the models of positive masculinity (potent, young, experienced) and positive femininity (inexperienced, young, unmarried, sexually innocent woman) as outlined by Lövkrona (1998). In addition, the same material provides evidence of the argument that sexual folklore expresses forbidden contents, while at the same time it projects fears and anxieties. Although not many in number, the tales which I have labelled "sex as a cure" are actually narratives in which free, uncensored, and unfettered expression of female sexual desire comes out in the open. Although veiled in a witty narrative design in which the desire for sex is substituted with a desire for cherries or grapes, these stories allow a taboo topic - that of women's sexual appetite - made unambiguous with the reference to food, to transgress the watchful eye of the society and be freely expressed. The same claim is equally applicable to the tales in which women openly commit adultery, even admitting it. In addition, in the group of tales in which adultery is a weapon of vengeance against the mistreating, jealous husband, one can easily recognize the presence of the symbolic fear of castration, or even impotence of the husband who is unable to treat his wife properly. The purpose of these narratives may be twofold: on the one hand to project the male's fear of being cheated on, allowing the expression of this fear, while on the other, by putting the man's weakness, flaw in character, to a public ridicule, to warn husbands of the possible outcome of their mistreatment and thus make them conform to patterns of accepted behavior. It is exactly through a story, as maintained by Bascom, that the society intends to express disapproval, to warn and even criticize (Bascom 1954). The role of criticism, as far as the present corpus goes, is highlighted especially in the tales that Pilichkova (2009) terms as anticlerical. The difference, however, as compared to the present material, is that the anticlerical tales Pilichkova writes about are critical of the priests' sexually improper behavior, and an excess of lust as phrased by Ajdačić (2000), while the improper behavior of the priests in the present material is caused by their will to have excessive control over their young wives. In this context, the act of adultery is symbolically not only a criticism of the rigidity and the will for power of the clerical cast, but also a free expression of sexual desire. 
Regarding the sexual roles, relations, and structures constructed through the tales, the existence of the experience-inexperience dichotomy in which men are the seducers and women merely a game in the play of seduction worked out through figurative language, points to a sexual relationship in which men are portrayed as both sexually prowess, cunning, and active sexual agents, while women are deprived of the opportunity to act as agents of sexual behavior, and their image as sex objects is highlighted instead.

Ironically, a woman can be a subject of sexual engagement, and even an initiator of it, only through the act of adultery. It is only through unfaithfulness that she can initiate and achieve gratification of her desires. But even then, the end of such sinful gratification is not to satisfy her own desires and fantasies but rather to serve as a didactic and moralizing instrument of retaliation for the misbehaving husband. The act of adultery is thus presented in a framework in which the act is legitimized and allowed to happen because it is a just punishment, which many of the narratives confirm through the husband's end lines, acknowledging his own misdoing with the words "It served me well!". Without doubt, this carries an implied warning to all males in the audience that their own misconduct may be sanctioned in a similar manner. The narrative then is not about female sexual freedom, agency or opportunity to act out of one's own will, but rather a moralizing political tool of keeping men well-behaved, and thus preserve conformity to proper, accepted behavior.

While research has identified many cases in which sexual jokes are a means of female empowerment against the patriarchic society and the fixed, maleconstructed gender roles and hierarchies it imposes on women (Crawford 1995; Franzini 1996; Bing \& Heller 2003; Reichenbach 2015), the jokes analyzed here mostly evidence their psychological function as an outlet that allows free expression of repressed, forbidden sexual impulses. Additionally, the analysis of the sexual jokes suggests that these particular examples work more as means of subordination and disempowerment of women, rather than tools of resistance to and challenge of male structured gender hierarchies.

One of the dominant images of the women present in this corpus is that of an adulterous, promiscuous character who freely speaks about her sexual urges and fantasies. Such a speech may confirm Freud's concept of jokes as free expressions of socially suppressed, forbidden impulses, but the representation of women as bearers of immoral behavior, manifested through adultery and promiscuity, shows that there is much more involved in this particular representation than meets the eye. The image of the woman as unfaithful and promiscuous can be taken as an index of modern-day society and its sexual mores, anxieties, and hypocrisy. The difference in the representation of the two genders, as related to the themes of adultery, promiscuity, and libidinal 
drives, is intriguing to say the least. Firstly, the frequency of the occurrence of the theme 'wife's infidelity and promiscuity' in the jokes $(n=72)$ is much higher than the frequency of the same motif as related to men $(n=12)$. The quantitative misbalance in the representation may suggest that women are morally frail, immoral, unable to resist a temptation. More importantly, their infidelity and lack of remorse are represented as a merciless act, since sexual intercourse for them is an end in itself and not a didactic, moralizing instrument as is the case with the folktales. Contrary to this image of the wife as an untamable shrew, the husband is an innocent victim of adultery, often represented sympathetically as a fool, a naïve husband believing his wife. Another astonishing aspect related to the construction of genders, concerned with the motif of adultery, is the presence/absence of the cheated partner. In the jokes in which men are unfaithful, the cheated spouse is implied, talked about in the narrative, but very rarely, if ever, physically present in the act of the adultery. Differently than this, in the jokes where women commit adultery, they are very often caught red-handed. The cheated husband is an eye-witness whose presence is offered for a laugh or sympathy by the male audience. Moreover, the representation of the male's infidelity is mitigated, made socially more acceptable either by being narrated through a male child perspective or through a verbal pun. Generally, there is a perverted logic in representing women as unfaithful and promiscuous, while men are naïve, sympathetic victims, especially in light of the fact that in modern-day societies it is men who tend to be more promiscuous and unfaithful. Yet the humorous narratives create an opaque world turned upside down. The reason for doing so, I believe, is the intention to discipline women by presenting them negatively as social deviants (unfaithful and promiscuous) in order to be symbolically tamed and punished through ridicule. This logic, however, seems to potentially have another motive, and that is to alleviate and purify men from the sins committed in the real world. The imaginary world of the joke, in which women are unfaithful and men are innocent victims, offers a denial of responsibility for the acts committed in the world where men are far more sexually promiscuous and unfaithful. As such, these jokes could potentially function as a collective therapy for men to alleviate their guilt, and gain moral, although imagined, superiority over women.

Condemnation and fear of sexually active women, even in the imaginary joke world, also underlies one of the key male fears as represented in the jokes about men's impotence, and that is the fear of castration. In all of these jokes men are being made fun of for not being able to satisfy their partners, thus alluding to the socially constructed ideal of a man as potent, uncompromisingly willing sexual actor, an ideal that is typically masculine and masculinizing, which can also be observed in the manner homosexuality is constructed. Male homosexuality 
is acknowledged, is made fun of, and detested for its unnatural nature that goes against God's design (Davies 2011), but also rejected because penetration means being dominated, something inadmissible for men. At the same time, the attitudes on female homosexuality are harsher, creating repulsive images like a vibrator turning into a pumpkin in the female vagina, as constructed in the joke shown above (section Homosexuality), as if it is both unimaginable and inadmissible for women to be anything but heterosexuals. The image also speaks of a male view in the sense that while male homosexuality is unacceptable, women's is unimaginable. Additionally, the non-existence of examples of womento-men sex transition may serve as a proof of the attitude that such a transition is unimaginable as well, and hence unacceptable, implying that one becomes a man only by birth (naturally), and not through surgery.

Finally, the sexual discourse constructed through folktales further confirms the existent findings and, surprisingly, looks more democratic. On the one hand, such discourse favors male ideals of femininity (unmarried and inexperienced) and masculinity (experienced, smart) and deprives women of sexual agency, making them objects of sexual actions. On the other, it gives women the right to openly express sexual desire, albeit metaphorically, by reference to appetite for food, but more importantly the engagement in illicit, adulterous intercourse; ironically, it is a means of women's empowerment by which they want to make disobedient men conform to acceptable patterns of behavior, and to discipline them. Sex for these women is an enjoyment, but also a means to keep some balance in society.

Differently than this, sexuality constructed through jokes is more poignantly reflective of masculine views and attitudes, of patriarchally conceived, organized, and represented gender roles and relations. What is more interesting is that this discourse is not a mirror held up to society but more a male's perverted fantasy projected upon it. The material depicts a world in which women's sexual agency is attributed as deviant (unfaithful, promiscuous, and lustful) and needs to be sanctioned through ridicule. Conversely, the man's deviant behavior is mitigated, he is reminded that he needs to uphold the socially constructed image of him as a sexually potent figure, which at the same time projects men's greatest anxiety - sexual underperformance. By taming and punishing females' sexual appetite and behavior and ridiculing men's sexual underachievement, the jokes seem to be working towards the same end - the re-assertion of males' sexual dominance and females' subordination, even if in imaginary form. Even jokes about homosexuality and sex education confirm that the relation manwoman is not one of equality but of asymmetry. 


\section{CONCLUSION}

While the textual analysis of the sexuality constructed in erotic tales confirmed some of the existent and already studied gender inequalities constructed through the genre of folktales, it also revealed a moralizing social potential of tales to at least flag, if not sanction, the improper behavior by some groups of people, in this case priests and mistreating husbands. The woman in the folktales may be inexperienced, lustful, even empathetically reprimandable, but she is far from the Babylonian whore, the image constructed in the world of jokes. While we are not able to remedy any of the potential negative social effects that the discourse of sexuality produced by folktales may have caused, it is both possible and urgent to undertake the challenge of fighting against the gross stereotype about women, constructed by means of the jokes. While contextually studying the use of such jokes in a conversational context may point to actual motives, ends, and reception(s) of the stereotypes, the introduction of the genre in contexts where the samples may be offered to the attention, inspection, and mostly critical examination of the audience, is a more poignant method of fighting this injustice. Education that aims to promote critical thinking and gender equality can be one of such contexts. After all, the idea of using folklore as a didactic tool is far from being new (see Dundes 2007), yet exposing gender-biased hierarchies to pupils is both novel and necessary.

\section{NOTES}

1 See http://www.pelister.org/folklore/erotic_folktales/index.html.

2 The four functions Bascom speaks of are eventually reduced to one, Sims and Stephens (2005: 176) argue - that of maintaining the stability of culture. Although the functions of education, maintaining conformity, and validating culture directly relate to its maintenance, it is worth noting that escapism may have a conservative function that allows members to vent out the dissatisfaction caused by the culture's institutions and conventions, but it may also have a subversive function of, at least symbolically, challenging the same institutions in hope for a change.

3 For a fully-fledged criticism see Oring (1977).

4 A teacher in Islam.

5 See http://www.pelister.org/folklore/erotic_folktales/index.html.

6 See www.vicoteka.mk.

7 The punch line and its understanding rely on the cultural knowledge, actually an urban legend, that it takes approximately seven years for the students of Faculty of Electric Engineering to finish their studies. At the same time the punch line draws 
on the polysemy of the word "finish", which can refer to the ending of an action (as in "finish the studies") as well as to the act of male ejaculation.

\section{REFERENCES}

Afanasyev, Aleksandr 1966 [1872]. Russian Secret Tales: Bawdy Folktales of Old Russia. Baltimore: Clearfield.

Ajdačić, Dejan 2000. O smjesnom i o moralizmu u erotskim pricama. [On the Laughable and the Moralizing in the Erotic Tales.] In: D. Ajdačić (ed.) Erotsko u folkloru Slovena: Zbornik radova. [The Erotic in the Folklore of the Slavs.] Belgrade: Stubovi kulture, pp. 474-506.

Bascom, William R. 1954. Four Functions of Folklore. The Journal of American Folklore, Vol. 67, No. 266, pp. 333-349. http://dx.doi.org/10.2307/536411.

Bing, Janet \& Heller, Dana 2003. How Many Lesbians Does It Take to Screw in a Light Bulb? Humor: International Journal of Humor Research, Vol. 16, No. 2, pp. 157182. http://dx.doi.org/10.1515/humr.2003.009.

Cepenkov 2007 = Tsepenkov, Marko. Erotski prikazni. [Erotic Tales.] Skopje: Feniks. Crawford, Mary 1995. Talking Difference: On Gender and Language. London: SAGE.

Crawford, Mary 2003. Gender and Humor in Social Context. Journal of Pragmatics, Vol. 35, No. 9, pp. 1413-1430. http://dx.doi.org/10.1016/S0378-2166(02)00183-2.

Davies, Christie 2011. Jokes and Targets. Bloomington, Indiana: Indiana University Press.

Dundes, Alan 1966. The American Concept of Folklore. Journal of the Folklore Institute, Vol. 3, No. 3, pp. 226-249. http://dx.doi.org/10.2307/3813799.

Dundes, Alan 2007. The Meaning of Folklore: The Analytical Essays of Alan Dundes. Edited by Simon J. Bronner. Logan, Utah: Utah State University Press. DOI: 10.2307/j.ctt4cgrzn.

Franzini, Louis R. 1996. Feminism and Women's Sense of Humor. Sex Roles, Vol. 35, No. 11/12, pp. 811-819. https://doi.org/10.1007/BF01544094.

Freud, Sigmund 1960 [1905]. Jokes and Their Relation to the Unconscious. New York \& London: Norton.

Foucault, Michel 1978 [1976]. The History of Sexuality. Vol. 1. New York: Pantheon Books.

Grzybek, Peter 2000. Juznoslovenski erotski folklor: Zapazanja o narodnoj erotskoj frazelologii iz Dalmacije. [South Slav Erotic Folklore: Observations on Folk Erotic Phraseology from Dalmatia.] In: D. Ajdačić (ed.) Erotsko u folkloru Slovena: Zbornik radova. [The Erotic in the Folklore of the Slavs.] Belgrade: Stubovi kulture, pp. 295-325.

Gura, Aleksandr V. 2005. Coitus in the Symbolic Language of Slavic Culture. Folklore: Electronic Journal of Folklore, Vol. 30, pp. 135-154. http://dx.doi.org/10.7592/ FEJF2005.30.gura.

Hall, Stuart 1980. Encoding/Decoding. In: Stuart Hall \& Dorothy Hobson \& Andrew Lowe \& Paul Willis (eds.) Culture, Media, Language: Working Papers in Cultural Studies, 1972-79. London: Hutchinson, pp. 128-138. https://doi.org/10.1075/ z.184.211hal. 
Karadžić, Vuk Stefanović 1979. Crven ban: erotske narodne pesme. [The Red "Ban": Erotic Folk Songs.] Beograd: Prosveta.

Karanović, Zoja \& Jokić, Jasmina 2009. Smehovno i erotsko u srpskoj narodnoj kulturi $i$ poeziji. [Funny and Erotic in the Serbian Folk Culture and Poetry.] Novi Sad: Filozofski fakultet.

Kline, Paul 1977. The Psychoanalytic Theory of Humour and Laughter. In: Anthony J. Chapman \& Hugh C. Foot (eds.) It's a Funny Thing, Humour. Oxford: Pergamon Press, pp. 7-12.

Kostić, Aleksandar 1978. Seksualno u našoj narodnoj poeziji. [The Sexual in Our Folk Poetry.] Beograd \& Zagreb: Medicinska knjiga.

Krauss, Friedrich S. et al. (eds.) 1883. Kryptadia: Recueil de documents pour servir à l'étude des traditions populaires. Vol. 1. Heilbronn: Henninger Freres. Available at http://www.horntip.com/html/books_\%26_MSS/1880s/1883-1912_kryptadia_ (HCs)/index.htm, last accessed on 8 March 2019.

Krauss, Friedrich S. 1904-1913. Antropophyteia: Jahrbuch für folkloristische Erhebungen und Forschungen. Vol. 1-9. Available at http://www.horntip.com/ html/books_\%26_MSS/1900s/1904-1922_anthropophyteia_(HCs)/index.htm, last accessed on 8 March 2019.

Krstanović, Zdravko 1984. Erotske narodne pjesme. [Erotic Folk Poems.] Split: Vlastito izdanje.

Legman, Gershon 1962. Misconceptions in Erotic Folklore. The Journal of American Folklore, Vol. 75, No. 297, pp. 200-208. http://dx.doi.org/10.2307/537722.

Legman, Gershon 1968. Rationale of the Dirty Joke: An Analysis of Sexual Humor. New York: Grove Press.

Levine, Jacob \& Redlich, Fredrick C. 1955. Failure to Understand Humor. The Psychoanalytic Quarterly, Vol. 24, No. 4, pp. 560-572. http://dx.doi.org/10.1080/21674 086.1955.11926004.

Lövkrona, Inger 1998. Erotic Narrative and the Construction of Gender in Premodern Sweden. Journal of Folklore Research, Vol. 35, No. 2, pp. 145-156. Available at https://www.jstor.org/stable/3814753, last accessed on 4 March 2019.

Malinowski, Bronislaw 1926. Myth in Primitive Psychology. New York: Norton.

Martinoska, Ana 2007. Goliot na gosti: Antologija na makedonskiot erotski folklor. [The Naked Guest: An Anthology of Macedonian Erotic Folklore.] Skopje: Mi-An.

Miceva, Evgenija 2000. Erotski folklor i njegovi nosioci. [Erotic Folklore and Its Bearers.] In: D. Ajdačić (ed.) Erotsko u folkloru Slovena: Zbornik radova. [The Erotic in the Folklore of the Slavs.] Belgrade: Stubovi kulture, pp. 465-473.

Mrduljaš, Igor 1980. Kudilja i vreteno: Erotske narodne pjesme. [Whirl and Spindle: Erotic Folk Songs.] Zagreb: Znanje.

Oring, Elliot 1977. Rationale of the Dirty Joke: An Analysis of Sexual Humor. First Series by G. Legman; Rationale of the Dirty Joke: An Analysis of Sexual Humor. Second Series by G. Legman. Review. Western Folklore, Vol. 36, No. 4, pp. 365-371. DOI: $10.2307 / 1499200$.

Pandurević, Jelenka 2016. Folklorni Erotikon izmetsu Obredne i Poetske Metafore. [The Folklore Eroticon between the Ritual and Poetic Metaphor.] Knjizevna istorija / Literary History, Vol. 48, No. 159, pp. 9-36. Available at https://dialnet.unirioja. es/servlet/articulo?codigo $=6028999$, last accessed on 4 March 2019. 
Penushliski, Kiril 1989. Makedonski erotski prikazni. [Macedonian Erotic Tales.] Skopje: Misla.

Pilichkova, Sevim 2009. Erotski elementi vo turskoto narodno tvoreštvo od Republika Makedonija. [Erotic Elements in the Turkish Folklore in Macedonia.] Skopje: Institut za folklor "Marko Cepenkov".

Radcliffe-Brown, Alfred R. 1952. Structure and Function in Primitive Society: Essays and Addresses. Glencoe, Illinois: The Free Press. Available at https://archive.org/ details/structurefunctio00radc, last accessed on 26 February 2019.

Reichenbach, Anke 2015. Laughter in Times of Uncertainty: Negotiating Gender and Social Distance in Bahraini Women's Humorous Talk. Humor, Vol. 28, No. 4, pp. 511-539. http://dx.doi.org/10.1515/humor-2015-0098.

Risteski, Dragan 1994. Makedonski erotski pesni. [Macedonian Erotic Poems.] Skopje: Studenstski zbor.

Ruch, Willibald \& Köhler, Gabriele 1998. A Temperament Approach to Humor. In: Willibald Ruch (ed.) The Sense of Humor: Explorations of a Personality Characteristic. Berlin: Walter de Gruyter, pp. 203-228. https://doi.org/10.1515/9783110804607-011.

Scott, James C. 1990. Domination and the Arts of Resistance: Hidden Transcripts. Yale: Yale University Press.

Sikimić, Biljana 2013. How to Read Riddles: Erotic World of Cultural Plants. In: Zoja Karanović \& Jasmina Jokić (eds.) Plants and Herbs in Traditional Serbian Culture: Handbook of Folk Botany. Novi Sad: Faculty of Philosophy, pp. 71-84. Available at http://www.academia.edu/4873314, last accessed on 4 March 2019.

Sikimić, Biljana \& Otašević, Dorde 2000. Erotske narodne brzalice. [Erotic Folk Tongue Twisters.] In: D. Ajdačić (ed.) Erotsko u folkloru Slovena: Zbornik radova. [The Erotic in the Folklore of the Slavs.] Belgrade: Stubovi kulture, pp. 262-286. Available at http://www.academia.edu/3739665/, last accessed on 26 February 2019.

Sims, Martha C. \& Stephens, Martine 2005. Living Folklore: An Introduction to the Study of People and Their Traditions. Logan, Utah: Utah State University Press.

Smilevski, Nikifor 1993. Veleshki mrsni pesni. [Greasy Poems from Veles.] Veles: Radio 2000 .

Stanoev, Stanoj 2000. Seksualni vic, po materijalima iz bugarskog folklora. [Sexual Jokes According to the Bulgarian Folklore Material.] In: D. Ajdačić (ed.) Erotsko u folklore Slovena: Zbornik radova. [The Erotic in the Folklore of the Slavs.] Belgrade: Stubovi kulture, pp. 507-527.

Terseglav, Marko 1981. Klincek lesnikov. [Hazelnut Spike.] Ljubljana: Cankarjeva založba.

Velichkovski, Bone 1989. Makedonski erotski narodni pesni: Sekoj Petok urda jadam. [Macedonian Erotic Folk Poems: Each Friday I Eat Curds.] Kumanovo: Prosveta.

Vujkov, Balint 1990. Mrsne pripovitke: antologija bunjevačke erotske priče. [Greasy Stories.] Subotica: Osvit.

\section{INTERNET SOURCES}

http://www.pelister.org/folklore/erotic_folktales/index.html, last accessed on 25 February 2019.

www.vicoteka.mk, last accessed on 25 February 2019. 


\title{
RELUCTANT ENTREPRENEURS OF THE RUSSIAN FAR EAST: ANOTHER VIEW ON THE ECONOMIC STRATEGIES OF ENTREPRENEURS
}

\author{
Aimar Ventsel \\ Senior Research Fellow \\ Department of Ethnology, University of Tartu \\ e-mail: aimar.ventsel@ut.ee
}

\begin{abstract}
Research into private businesses in post-Soviet Russia began with the collapse of the Soviet Union. This paper focuses on a specific segment of private entrepreneurs who I call 'reluctant entrepreneurs', and revises the concept of a 'new entrepreneurship' in Russia. The people under study entered into business reluctantly in the early 1990 s, when salaries in state jobs were not paid. The majority of these entrepreneurs planned to either return to a public-sector job or maintain their affiliation with the state enterprises. This attitude contradicts the dominant approach in academic writing, in which private entrepreneurs in post-socialist countries see entrepreneurship as a new perspective and an act of self-fulfillment. The strategy of the entrepreneurs under study is also oriented against constant expansion and innovation. Moreover, in their activities entrepreneurs are led by local social norms that do not often support the earning of direct profit. Such practices are caused by the current economic climate in Russia, where the state shows little interest in the activities of small and medium-sized entrepreneurs. This article suggests that there is a need for new conceptual tools to analyze these facets of the private economy.
\end{abstract}

Keywords: informal economy, kinship, Russia, Sakha, small and medium entrepreneurs

The defining line between the socialist society and 'what came next' is apparently when the former 'economy of shortage' was transformed into a market economy, and entrepreneurship was officially legalized (see Verdery 1993, 1996). With the collapse of the socialist planned economy in Eastern Europe there emerged an entrepreneurial class associated with the Weberian tradition, and the appearance of a fundamental need for innovation, free thinking, and democracy (see Davidova \& Thomson 2003; Estrin \& Aidis \& Mickiewicz 2007; Gibson 2001; Peng \& Shekshnia 2001; Wegren 2000). At least in the Russian case, 
the enthusiastic expectations remained unfulfilled. While entrepreneurship in Russia has taken on different forms, it is rather related to the shadow economy, struggle, and crime than to any kind of free thinking or democratic ideology (see Cartwright 2001; Humphrey 2002; Kuznetsov \& Kuznetsova 2005; Tarasov \& Egorov \& Kulakovskii 2013; Ventsel 2005). However, the private economy continues to thrive, and plays an important role in everyday life in Russia. After private enterprise had been sanctioned in the Soviet Union in the late 1980s (McCarthy \& Puffer \& Shekshnia 1993: 128), it expanded quickly over the whole region and reached the easternmost territories in the early 1990s.

This article focuses on a segment of entrepreneurs in the Russian Far East, who I call 'reluctant entrepreneurs'. Such entrepreneurs often took up their new occupation not because they dreamed of becoming entrepreneurs, seeking a new trajectory in the life, but because biznes seemed to be their best option for survival in the $1990 \mathrm{~s}$, when government salaries remained unpaid, and the social security system was drastically dismantled (cf. Rasell 2009). With a few exceptions, people did not plan to be engaged in entrepreneurship their whole lives, but wished to return to the public sector. Many of them divide their time between their own enterprises and state-paid jobs. Moreover, their views on profit and expansion might contradict Western theories on leading a business successfully. As I show, such entrepreneurs are not an anomaly, and their strategies and logic are fully understandable given the current state of the market economy in Sakha-Yakutia.

\section{THE REPUBLIC OF SAKHA (YAKUTIA) AND ITS ECONOMIC ENVIRONMENT}

The Republic of Sakha (Yakutia) is the largest territorial unit of the Russian Federation and belongs to the easternmost administrative unit, the Far North Federal District, which is comprised of nine different territorial units. The republic is a large but sparsely populated territory covering more than three million square kilometers, with slightly less than a million people, 55 percent of whom are the titular ethnic group, the Turkic speaking Sakha. Approximately 73 percent of the population in the Republic of Sakha are urban.

The republic is famous for its diamond resources, producing 30 percent of the world's diamonds and almost 100 percent of Russia's diamonds. In addition to diamond mining, the Republic of Sakha has significant resources including gold, gas, oil, precious metals, coal, and timber. Natural resource extraction is the domain of big companies in the region, as is large-scale construction. The 
difference is that while mining and oil extraction are dominated by state-owned companies, in the construction sector private companies have the upper hand.

The official definition of medium or small enterprises remains blurred and changes constantly, but in 2009 181,514 small enterprises ${ }^{1}$ existed in the Russian Far North (Stepanova \& Nogovitsyn 2011: 49). Approximately 80 percent of these were "microenterprises" or enterprises that hired up to fifteen employees on a permanent basis. It must be mentioned that in relation to the number of enterprises per capita, the Far North is slightly below the average Russian level. In terms of regional distribution, about 47 percent of small enterprises are located in Primorsky Krai, 19 percent in Khabarovsk Krai, and approximately 8 percent in the Republic of Sakha (Yakutia) (ibid.: 49-59). Small enterprises tend to have very low investment and profit levels, and 60 percent of the small enterprises in the Russian Far North are engaged in wholesale and retail sales (Egorov 2006: 192; Stepanova \& Nogovitsyn 2011: 65).

In 2010, there were 115 medium-size enterprises and 4,952 small enterprises registered in the Republic of Sakha; from these 4,029 were classified as microenterprises. In the year 2009, small enterprises contributed only 6.6 percent of the regional GDP but gave work to 40 percent of the local workforce. In the Republic of Sakha, 80 percent of small and medium enterprises are concentrated only in four cities (the capital, Yakutsk; Neriungri, famous for its coal industry; Mirnyi, the center of diamond industry; and Lensk, another center for diamond mining). From the regional enterprises 400 are agricultural. The statistics shows that in Sakha 44.4 percent of small enterprises are engaged in wholesale merchandise, 22.7 percent in construction, 6.8 percent in real estate, and 5.7 percent in transport. The role of small-scale enterprises in different spheres can be high: 94.3 percent of services (bytovye uslugi) and 100 percent of the small bus transport market belongs to small enterprises, as does the majority of tourism, clothing repair, cargo transport, car and truck repair, and other services.

The low profit levels of such enterprises can be explained by the underdeveloped infrastructure and high energy costs in the region. Local economists have highlighted one peculiarity of small-scale enterprises: their need for highly skilled specialist labor is much lower than their demand for unqualified manual labor. Notwithstanding several federal and regional programs, the state has been unsuccessful in developing 'innovative' and modern high-tech small enterprises. In general, the statistics show that between 2004 and 2009 only 29 innovative small enterprises were established in the republic (Stepanova \& Nogovitsyn 2011: 56-57). As some local scholars argue, the reason is that big mining and production companies, with better financing and market pros- 
pects, dominate these spheres already and offer better salaries than a private enterprise (ibid.: 59).

This article draws on the fieldwork conducted in the Republic of Sakha in July and December 2013, and in July 2014, and personal extensive background knowledge of the region obtained over the last sixteen years. Each time, I spent three to four weeks in the region, conducting research mainly in the capital of Yakutsk, but also in villages near Yakutsk and in the Verkhoyansk district (approximately 1,000 km northeast from Yakutsk). During the fieldwork we recorded twelve formal interviews ${ }^{2}$ with different entrepreneurs whose enterprises were classified as small or microenterprises. Interviews were also made with different government officials, including one former Minister of Economy of the Republic of Sakha. Additionally, I talked to various other entrepreneurs, visited their enterprises, and observed how they operated. All but one entrepreneur had started their business out of necessity in the 1990s. One woman was the spouse of a wealthy businessman, whose husband funded her bridal shop because, as she put it, she had always dreamed of such a store. Nevertheless, she also perfectly fitted the ideal, sharing similar attitudes and behavior patterns with other subjects. Entrepreneurs under study were engaged in various sectors: fishing and hunting enterprises, food shops, laundries, construction firms, tourist ventures, and a hair salon. Some of the informants had different small enterprises, none of them had studied the profession they were engaged in at the time of the encounter, and for all the respondents their current enterprise was not their first but rather a third or fourth one. All but one were ethnic Sakha (one was Armenian), half of my respondents originated from a village, roughly 70 percent were women, and their age varied from mid-thirties to late fifties. Statistics presented in this article came from the works of local economists.

\section{CONCEPTUAL CONFUSION}

Existing studies on private entrepreneurship in Eastern Europe reveal huge gaps when it comes to the question about what motivated the actors to start their biznes in the first place. Notwithstanding that researchers who study entrepreneurship tend to be critical to the utilitarian approach of the neoclassic economy (Nee \& Young 1991), ${ }^{3}$ the general impression given by academic literature is that individuals embraced their new occupation more or less voluntarily, and even with some degree of enthusiasm. Indeed, studies of entrepreneurship in post-Soviet Russia and grounded in anthropology (Hann 2000; Köllner 2013 [2012]), economics (Berkowitz \& DeJong 2001; Estrin \& Aidis \& Mickiewicz 2007) and sociology (Barsukova \& Radaev 2012; Sakaeva 2012) indicate indi- 
rectly that the actors saw the new market economy as an opportunity. Another popular argument in academic literature is the 'path dependency' argument, an assumption that entrepreneurs have role models, have been active in the business previously, or that new post-socialist enterprises follow the footsteps of similar state companies of the socialist period (Alanen et al. 2001; Nee \& Young 1991; Pickles \& Smith 1998; Stark 1991). In general, one expects that a person who enters into a small business possesses the wish to be engaged in entrepreneurship, and has some vision or strategy as to how they will develop the business. All these explanations are more or less questionable regarding the nature of a private business in the late Soviet Union and the first post-Soviet period. Indeed, people who changed occupation to open a kiosk or a private cafe had virtually no role model, and very little understanding of how to operate in a - principally unregulated - market economy. Another approach which raises an eyebrow is that many researchers continue to speak about the 'new' private entrepreneurship even when it has existed for more than a decade or two (see, e.g., Kuznetsov \& Kuznetsova 2005; Polischuk 2001). ${ }^{4}$

One theoretical framework analyzing entrepreneurship in Russia, relied on by various authors, is the concept of blat (clout, profitable connections). The impression, when revising literature on the topic, is that blat is a natural part of Russian private business. Russia is described as a 'network state' (Humphrey 2012), where political and economic networks can have a semi-feudal nature (Gambold Miller 2003; Shlapentokh 2007). The originator of the academic concept of blat - Alena Ledeneva - argues that it was a Soviet era strategy, a system of favors, to gain access to scarce resources, mainly goods (Ledeneva 1998, 2006). Blat is usually viewed as a circle of people engaged in a delayed reciprocity. This circle is a closed one and based on a 'negative solidarity' or mistrust of outsiders (Radaev 1998, 2005). Moreover, the reciprocal group can be seen as a network of people with common interests, based on pragmatic calculations, and not on kin, clan, or other social or cultural ties. Proponents of the concept admit that the nature of blat has changed and it has shifted from the economy of favors to a cash economy, since access to goods in Russia is now limited by one's wealth and not by availability. In general, modern blat in academic literature is interpreted as an informal network linking entrepreneurs and political power structures (Puffer \& McCarthy \& Boisot 2010). Via such connections, entrepreneurs can exploit state resources or sign profitable deals with state structures, for example ministries (Hsu 2005). Indeed, post-Soviet Russian history is full of corruption scandals where private enterprises receive overpaid orders to build, supply the government institutions with company cars, software, and so on. ${ }^{5}$ 
When in the Soviet era blat had a certain ideological aspect, then today it is seen as purely economic networking (Ledeneva 2008). Blat is described as a predatory behavior against those who are outside the circle (Hsu 2005: 312). Ledeneva (2008: 130) even argues that it is an individualistic, not communitarian practice, where every participant acts solely out of their own interests. This statement is in accordance with the view that Russia is largely a 'distrustful society' (Estrin \& Aidis \& Mickiewicz 2007). Nevertheless, it is difficult to agree to Ledeneva's statement that the word blat is hardly used today and people prefer other terms. In the Republic of Sakha, at least, the word is used to indicate exactly the same kind of corruption that links governmental and entrepreneurial networks. The expression is, however, rarely used to describe reciprocal practices between ordinary people or private enterprises. It is not the topic of this article, but blat is hardly a Maussian gift exchange as some authors argue (Hsu 2005; Humphrey 2000; see also Ssorin-Chaikov 2000), but rather a cynical and sinister patron-client relationship.

For the abovementioned reasons, blat as a concept seemed unsuited for the analysis of the attitudes, strategies, and practices of the entrepreneurs examined. While blat is in some sense a 'genuine Russian' phenomenon, more suited for the purpose of this article is the 'genuine Chinese' concept of reciprocal networking - guanxi. In contrast to blat as a reaction to the Soviet economy, guanxi dates back to the pre-Socialist period. Several authors acknowledge there are many similarities between the blat and guanxi as a 'survival kit' or 'safety network' (Hsu 2005; Ledeneva 2008). Both are reciprocal, informal, and based on delayed reciprocity. Gradual differences are, however, more important. Guanxi, as blat, is a network and practice that constantly changes its forms. There are, nevertheless, certain features that characterize most variations of guanxi. First of all, guanxi is an inclusive and constantly expanding network. At its core, guanxi is based on kinship ideology, linking both biological and fictive kin. This network channels not only the transmission of goods and money, but also favors. In fact, some scholars argue how the most important part of guanxi is indeed the 'small favors', which are sometimes exchanged in a highly ritualistic way.

\section{RELUCTANT ENTREPRENEURS}

Below are presented several cases from the pool of informants. Each individual has his or her own reasons to be an entrepreneur, but there are also common features and attitudes making them part of a distinct group of entrepreneurs in the Republic of Sakha. 
Alena is in her late thirties, and works as a book-keeper in municipal government structures, where she earns her main income, as does her husband. They, nevertheless, see themselves principally as managers of a fishing enterprise. The enterprise is located on the coast of the Arctic Ocean, in Tiksi, a former military settlement, and a big Soviet-era trade port. Alena's mother established the fishing enterprise in the mid-1990s and since then it has existed as a family enterprise. All employees of the small enterprise are family members and the purpose of the enterprise has always been guaranteeing kin people with an income. The northern fish is considered a delicacy in the Republic of Sakha and has traditionally been in high demand in the southern cities. In recent years the market has, however, been overflooded. Ten years ago the northern fish was difficult to acquire in Yakutsk, today markets and street corners are literally full of street vendors who sell such fish. The prices have fallen and fishing enterprises are struggling to make ends meet. Alena is taking care of marketing and all the paperwork (licenses, taxes, state subsidies) whereas her husband is organizing the transport of the catch to Yakutsk. This requires certain skills and good connections. The fish is usually bought by state and private enterprises, and the prices vary. When Alena sells the catch to a state enterprise then she is entitled to state subsidies, but she said that the private buyers pay more. Therefore, to have the optimal outcome, costs for transport should be calculated carefully, and also the paperwork needed to sell fish legally. Both - Alena and her husband - admit that they do not earn much when managing the enterprise, as the priority is to pay salaries for their relatives in Tiksi, and also obtain supplies for the fishing season. When I asked Alena why she was engaged in the enterprise at all, she gave me a long stare and said: "How can I give up an enterprise that my mother established? And what will happen to all the people?" (personal communication, 2013) While managing the fishing enterprise, Alena has also tried other activities. For many years she ran a French-style café, offering pastries and different coffees. She quit when she had problems finding skilled workforce to maintain the quality of the products. This café was also a route for many of her rural-origin relatives to start a new life in the city. This was problematic because young relatives often left unexpectedly when they managed to find a more respectable and well-paid job.

Marfa is in her mid-fifties, and has a laundry in an old Soviet concrete block district of Yakutsk. She was previously a daycare teacher, but when in the early nineties wages were not paid in Russia, she decided to open a kiosk selling everything from beer to cheap jewelry, to cleaning liquid, akin to tens of thousands of kiosks in Russia. Marfa struggled hard to support her family and raise her son. Over time her business did well and she opened more kiosks. In the mid-2000s she was offered some laundry machines and so she switched 
occupation. Located in the basement of a tenement building, there was no sign for the laundry, which surprised me. The reason is that Marfa finds customers only via word of mouth or through personal contacts. In recent years Marfa has found valuable customers such as restaurants needing to wash their tablecloths regularly. The enterprise hires only a few female pensioners, as a rule, illegally, i.e., not registered and taxes unpaid. Marfa sees it as a kind of charity, assistance for pensioners in need of money. Her son helps with managing the laundry and has opened a workshop in a garage on the property where they both live. He repairs cars and motorcycles, also not paying any taxes. Marfa is also a coowner of a shop in one of the northern villages. Another owner is her sister, and Marfa's task is to buy and organize transport for different goods to be sold in the village. Both have decided not to sell alcohol, despite the fact that this is the easiest way to make a profit in remote northern settlements. "We do not support it [alcohol consumption]! We support ZOZh!"' (Marfa, personal communication, 2013)

Ivan is in his late fifties and lives in the remote northern village of Saidy. Saidy is located in the Verkhoyansk district and can be reached only by a 4-8hour motorboat trip from the district center in the summertime. In winter, when the river is frozen, trucks use it as a winter road. Approximately 700 people live in the village, a settlement of cattle herders, hunters, and fishers, with a strong sense of community. Even for a remote Arctic village, Saidy has an extraordinarily strong informal economy. Most of the hunting, transport service, cattle husbandry, and fishing is on an informal basis. Fish, milk, and meat are sold without any official record. The village has no official shops selling food and other consumables, and all three existing shops are technically illegal. A few years ago the community decided to ban the sale of alcohol in the village, and as the head of the village administration told us, they decided to allow the shops to exist under the condition they did not sell any alcohol. Ivan got into shop-keeping accidentally. His son-in-law, who is an entrepreneur in Yakutsk, learned how shops are run illegally in Saidy, without any license, registration or other paperwork. He suggested that Ivan opens a shop and delivers supplies directly from Yakutsk. Ivan's shop - and all the other shops - look like any other ordinary multifunctional store: shelves, price labels, and a freezer in the corner. Ivan's shop is well stocked, regular foodstuff, cigarettes, and clothes, he even sells red caviar and expensive cheese. All the goods are delivered from Yakutsk; the profit is split with the son-in-law. Ivan is officially an unemployed pensioner, but in reality a full-time shopkeeper. Nevertheless, he seems to be not too enthusiastic about his current career. "There is no work in the village. This is why young people leave. Someone of my age, I have no place to go. Everything costs money, so you need a job. This job is as good as any other. Sure, it would be better if it paid my pension..." (Ivan, personal communication, 2014). 
Sveta is in her late thirties and works as a sports teacher at a school in Yakutsk. She is also a fully licensed trader and entrepreneur. She needs the license to buy goods for her sister's shop in a village in the north central district of the republic. Thanks to the license, Sveta can officially hire trucks to send the ordered goods to the village. The document also entitles her to buy goods from wholesalers. Alongside being the supplier for her sister, Sveta has her own small additional income in the village where most people are related by kinship ties.

Sometimes people ask me to buy something. Like a fridge or furniture. Sometimes very specific clothes or ... when they order these things I usually send them to the village by truck. I do it almost for free. Let's say, I take 1000 rubles for buying a fridge. It is not that much, rather a symbolic amount because a fridge costs a lot. And organizing transport takes time. (Sveta, personal communication, 2014)

In general, Sveta engages in her own small private business because she can send the ordered goods using the trucks she fills with consumables for her sister's shop. There exists a practical agreement between her and her sister, and the village community. Both women know most of the village population and are linked to them via various kinship ties or common biography - they went to school together, played together as children, were long-time neighbors, their parents were friends, and so forth. Sveta can send bigger items, like fridges, to the village when there is free space on the truck. While Sveta's sister does not earn anything from their enterprise, people can become impatient and ask her how long they have to wait for a thing they have already paid for. Therefore, in order to stay on good terms with the neighbors, the sister has to allow the transportation of certain items, even when she could use the place on the truck for things for the shop. As Sveta told me: "It is sometimes difficult to distinguish whether you help your old childhood friend or make business" (personal communication, 2013). Answering my question about why people prefer to order certain goods from her and not her sister, Sveta replied that it was faster and easier to ask someone for that kind of favor: "I can always run and buy that cupboard or jacket when going to school or after the lessons. Otherwise it would be on the order list and it could take few truck loads before it arrives" (personal communication, 2013). She was adamant that she would continue to work as a schoolteacher:

It is good to be in a state job. You have all the bonuses [Rus. 'Igoty'] like one free trip inside Russia for a vacation, insurance, sick leave compensation and some more benefits that one does not have when working for a private entrepreneur. (ibid.) 


\section{TRUST, MORALITY, AND RESPONSIBILITY}

Russia is described as a society of strong interpersonal trust based on networks (Gibson 2001) in an economic environment where "honesty does not pay" (Radaev 2005: 114). On the other hand, small and medium-size businesses are adept at being engaged in an informal and illegal economy in order to "escape state regulations on production and transactions" or to absorb risks (Beneria 1989: 184). The question that remains is whether we can interpret the semiinformal economic networks of Sakha entrepreneurs in neo-classical terms, as a strategy to increase profit to the maximum? The described case studies, and other cases I encountered, have one common feature: their owners want to keep as far away as possible from the state structures. Entrepreneurs tend to be skeptical about the state but their skepticism is caused rather by the system of social norms than by the attitudes or politics of state institutions (cf. Nee \& Young 1991: 297). Many scholars and commentators admit that Russia is not the friendliest country for entrepreneurship (Agarwal 2007; Berkowitz \& DeJong 2001; Gustafson 1999; Hedlund 1999). In the Republic of Sakha, the relationship between entrepreneurship and the state is, however, unexpectedly calm. In some interviews I asked the entrepreneurs whether the state tax officials ever show any interest in small enterprises. Marfa explained that in the Republic of Sakha tax officials largely ignore small and medium-size enterprises. "They receive a certain percentage from any fine they extract from the enterprises. The situation is that the fines are much bigger when you deal with big companies. In our case it makes a few thousand rubles and is not worth it" (personal communication, 2013). This was also confirmed by the former Minister of Economy of the republic, Aleksandr Kugaevskii. He explained that by law the tax officials receive a certain financial bonus according to how much they contribute to the republic's budget. Local economists explain such a policy with the economic priorities of the republic. The main attention of the state institutions is on big companies as major cash cows. Smaller enterprises are not very interesting for the state because they do not produce much, and are just economic interlocutors. Simultaneously, due to the low purchase power of the population, incomes of small enterprises are insignificant from the point of view of the state (Egorov 2006: 188, 192). The entrepreneurs certainly have to cope with corruption, bribe their way through the bureaucracy, or 'support' a local police officer financially. They, however, do not wish to have access to the state resources and wish for the minimum attention from the state institution. The impression is that the reluctant entrepreneurs reduce their contact with state structures to a minimum, and in some cases even operate in unmarked buildings without any public advertisement. Therefore, the practice applied by 
entrepreneurs under study is not "to secure personal benefits for the members of one's circle at the expense of the state" (Hsu 2005: 321; Peng \& Shekshnia 2001 ) but to avoid access to state resources and this way avoid contact with state institutions. Such a 'guerilla strategy' helps to maintain entrepreneurial 'flexibility' (Peng \& Shekshnia 2001), which is realized by diversification of risks through expanding into other spheres and establishing economically non-related new enterprises. Combining laundry with car repair or selling food products, yet staying small, helps to keep the business within the family without hiring outside managers. This and other aspects make the concept of blat, as stressed above, unsuitable for the current situation.

The research data suggests that while blat is rather an exclusive reciprocal circle, the networks I studied are inclusive or constantly expanding. The case studies referred to above (and others I did not mention) show the incorporation of new members, or using the existing kin-based contacts characteristic of the Chinese guanxi. Illuminating is a discussion I witnessed in one of my friend's office in December of 2013. When we were having a cup of coffee, the door opened and an elderly woman entered. She asked Gosha (the friend) whether he knew a hairdresser for a barber's salon. The subsequent chat revealed that the woman was an entrepreneur with a long history in local private businesses. She constantly switched from one occupation to other, expanding or closing enterprises according to how successful they were. She had started out like many of the entrepreneurs I met, as a trader on a market, then opened a small kiosk, was the first entrepreneur to start a small workshop producing toilet paper, and so on. At the moment of meeting me she had progressed to a corner shop business but also had two hairdresser's salons, one for women and another one for men. The reason why she had popped into Gosha's office was that they came from the same district. "Because we came from the same district and neighboring villages, we are like kinfolk. We are supposed to help each other. She knows I know many people and there is a possibility I can help" (Gosha, personal communication, 2013).

Sakha kin relationships are sometimes very confusing. In general, Sakha families nurture strong reciprocal ties between different generations, linking relatives living in various villages and towns. The biological kinship network is usually extended by fictive kin that can be, for instance, daughter's best friend or father's schoolmate (see also Ventsel 2005). Boundaries are even more blurred by the widespread tradition of adoption, where an adopted child will also maintain close ties with his or her biological parents. Notwithstanding the fact that a modern Sakha extended family stretches over several districts, the district of origin plays a crucial role in identification. According to existing 
social norms, people originating from one district should support each other whenever possible and in reality such support is often practiced. ${ }^{7}$

This practice is similar to the Chinese guanxi, constantly expanding networks on the basis of finding 'common ground' (Puffer \& McCarthy \& Boisot 2010: 455). Contrary to the 'comparatively narrow definition of friendship' in blat networks, the guanxi practice absorbs new members, and parallel to kinship ties there are instrumentalized friendship and fictive kin relationships (Hsu 2005: 321-322). Scholars argue that such a strategy makes guanxi more ritualized but also more predictable (Ledeneva 2008: 128). In the Sakha case, the solidarity and loyalty of actors is ideologically motivated by the stressing of a common territorial origin or family. The abovementioned discussion between Gosha and the lady entrepreneur started with a general exchange of news about relatives and life in the village, stressing their common origin. Such an ideology makes it possible to find help and provide support to new members often personally unknown to the actors. Similar to guanxi, Sakha entrepreneurs use their 'connections' not only to gain access to resources or negotiate business deals, but quite often to ask for favors. Despite the fact that the practice of exchanging favors is widespread in Russia and such 'small favors' help to cement reciprocal relationships, in modern times they are often related to the flow of cash (Humphrey 2012). The 'small gestures' strategy is common also in Chinese guanxi but it does not necessarily lead to a monetary transaction (Strickland 2010: 111). In the Sakha practice, favors are often returned with favors and mutual trust plays a central role in such exchanges. It must be mentioned that such an exchange of favors was even embedded in this research, because all the entrepreneurs I interviewed agreed to meet us as a response to a request from our common friends. Another expression of trust is looking for new employees using the network. This is based on the belief that exists in China where a guanxi friend is a good source to find a trustful employee (Puffer \& McCarthy \& Boisot 2010: 454-456). This contradicts with blat where friends of friends are treated with suspicion and such links tend to be used in a more contractual manner, i.e., favors and their prices are negotiated in advance (see Humphrey 2012; Ledeneva 2008).

As I have shown, Sakha entrepreneurial networks stretch geographically over several thousand kilometers and cover certain 'gray areas' (Chang 2011: 328), such as running illegal shops or hiring staff without informing the tax officials. The functioning of these networks, however, maintains a certain moral aspect that tends to contradict pure economic calculus. In the case of Alena, Marfa, Sveta, and Ivan, entrepreneurship involves a strong ideology of kinship reciprocity. In order to keep the business predictable and stable, they submit to earn less profit. The obligation of responsibility for kin people's wellbeing 
is especially obvious in Alena's fishing enterprise, but it is also apparent with many other entrepreneurs. Most interesting is the decision of the shop owners not to sell alcohol. In general, the entrepreneurs take an active position in what they think is in the community's interests. All entrepreneurs could have made huge profits by selling alcohol either legally or illegally, as is the widespread practice in northern villages. The refusal to sell alcohol is a powerful statement. Alcohol consumption in indigenous communities is a fiercely debated issue in the Republic of Sakha and is connected with the debate about the 'health of a nation' and 'maintaining the traditional way of life' (Krivoshapkin-Aiynga 1998; Lapparova 2002; Tyrylgin 2000). There is a need for more research on the topic but here 'supporting ZOZh' means adopting a larger framework of moral categories and shaping business strategies specifically. In some cases, like for Ivan in Saidy, it means following the community's decision to forbid the sale of alcohol in the village, but in all cases opposing the sale of alcohol signals a commitment to shared values and a readiness to disclaim 'dirty money' earned by harming the community. This step should not be interpreted as a cynical business strategy with leverage in the eyes of the community or as a purely altruistic move. Some of the informants truly believe that this is their contribution to the development of the community and to the future of the Sakha in general. Here the parallel could be drawn with the tradition of guanxi, based on a pre-socialist tradition of reciprocity and Chinese customs (Hsu 2005; Strickland 2010).

\section{CONCLUSION}

I think that the term 'reluctant entrepreneurs' is appropriate for a particular group of Sakha entrepreneurs because in many aspects their entrepreneurial biography and business morals contradict the profit-oriented neo-classical model of economy. This group of entrepreneurs is also hard to conceptualize in the academic understanding of blat, which to date dominates the research on Russian private entrepreneurs. In order to understand the nature of the group under study, one should also have some understanding about the regional economy in the Republic of Sakha. This is an environment where, notwithstanding the rhetoric, the regional government shows little interest in supporting small and medium-size enterprises. The focus of local economic policy is on big companies who in one way or another contribute the lion's share of the local budget. Therefore, small enterprises, despite the fact that they provide jobs for a significant part of the local labor force, are left to survive on their own terms. 
The 'reluctant entrepreneurs' are businesswomen and -men who entered the occupation largely out of necessity due to the economic chaos in Russia during the 1990s. In many cases they are not even today overtly convinced of the durability of their choice. Indicative is the fact that most entrepreneurs I have studied either maintain their state-paid jobs, or plan to return to the public sector before their retirement. Why they remain entrepreneurs is often due to a moral obligation, a lack of state-paid jobs, and the economic uncertainty in Russia which has increased after 2014.

It is interesting to look at the moral framework of these Sakha entrepreneurs. Here we can find a sense of moral obligation to kin and older people, responsibility for the community and one's own people at large. These aspects make the Chinese guanxi better suited as an analytic framework to discuss the 'reluctant entrepreneurs'. The emphasis on tradition, extended kinship, trust, and non-monetary reciprocity is common to the Sakha and Chinese cases. Moreover, as is the Sakha case under study, Chinese guanxi means open and constantly expanding networks in contradiction to the relatively closed circles of blat. The segment of entrepreneurs I called reluctant demonstrates that there are different ways of doing business in Russia and therefore a need for a conceptually more pluralistic approach.

\section{ACKNOWLEDGEMENTS}

This research was supported by the institutional research funding IUT 34-32 of the Estonian Ministry of Education and Research.

\section{NOTES}

1 The illustration for the ambivalence of the classification is a construction firm in Yakutsk. The enterprise has less than 15 permanent workers, which makes it a 'microenterprise'. These permanent workers are mainly engaged in management tasks. When the enterprise, however, signs a building contract, they hire dozens of construction workers from the former Soviet Central Asian republics or from Sakha villages, depending on the profile of the task - wooden buildings are mainly built by the Sakha whereas managers believe that the Kyrgyz and Uzbek are better suited for constructing concrete buildings.

2 The recordings of the interviews are in possession of the author of the article. All names of the informants were changed to guarantee their anonymity.

3 See criticism over the use of neoclassical theory in the analysis of post-socialist entrepreneurship in Estrin \& Aidis \& Mickiewicz (2006: 4) and Kuznetsov \& Kuznetsova (2005). 
4 This kind of approach is not unique to Russian studies. For instance, in the case of East Germany or the former GDR, one can still find researchers who see the region as static and unchanging, and complain about the 'existing GDR mentality' that hinders successful transformation, or view new private enterprises as something 'new' (Böhmer 2005).

5 The best source for current corruption scandals involving state officials or institutions is the website of a well-known Russian opposition figure, Alexei Navalny (see navalny. com).

${ }^{6}$ Zdorovye obraza zhizni or Healthy Ways of Life is a loose campaign in Russia promoting abstinence from alcohol and tobacco, combined with active ways of life such as engagement in sports.

7 The average Sakha greeting between two strangers is "Khantan syld'an?" (Where are you from?). It means that already at the beginning of a meeting strangers make sure of the district and kin affiliation of the interlocutor. Most Sakha, even when they are second- or third-generation urban dwellers, trace their origin back to some district and nurture that connection by hosting rural relatives when they come to the city (for example, on shopping trips). Rural relatives usually respond by taking with them 'village food' - meat, milk products or berries.

\section{REFERENCES}

Agarwal, Manmohan 2007. International Economic Management: Concerns of China, India, Russia. China Report, Vol. 43, No. 2, pp. 163-173. http://dx.doi. org/10.1177/000944550704300205.

Alanen, Ilkka \& Nikula, Jouko \& Põder, Helvi \& Ruutsoo, Rein (eds.) 2001. Decollectivisation, Destruction and Disillusionment: A Community Study in Southern Estonia. Aldershot: Ashgate.

Barsukova, Svetlana \& Radaev, Vadim 2012. Neformal'naia ekonomika v Rossii: kratkii obzor. [Informal Economy in Russia: Short Overview.] Ekonomicheskaia sotsiologiia, Vol. 13, No. 2, pp. 99-111. Available at https://ecsoc.hse.ru/2012-13-2. html, last accessed on 29 November 2018.

Beneria, Lourdes 1989. Subcontracting and Employment Dynamics in Mexico City. In: Alejandro Portes \& Manuel Castells \& Lauren A. Benton (eds.) The Informal Economy: Studies in Advanced and Less Developed Countries. Baltimore \& London: The John Hopkins University Press, pp. 173-187.

Berkowitz, Daniel \& DeJong, David 2001. Entrepreneurship and Post-Socialist Growth. William Davidson Institute Working Paper Number 406. Available at https:// pdfs.semanticscholar.org/dfc4/b7c2c2fb2734766caa150d1881dc09c282a4.pdf, last accessed on 20 November 2018.

Böhmer, Robert 2005. Der Geist des Kapitalismus und Aufbau Ost. Dresden: Thelem.

Cartwright, Andrew L. 2001. The Return of the Peasant: Land Reform in Post-Communist Romania. Aldershot: Ashgate. 
Chang, Kuang-Chi 2011. A Path to Understanding Guanxi in China's Transitional Economy: Variations on Network Behavior. Sociological Theory, Vol. 29, No. 4, pp. 315-339. http://dx.doi.org/10.1111/j.1467-9558.2011.01401.x.

Davidova, Sophia \& Thomson, Kenneth J. 2003. Romanian Agriculture and Transition toward the EU. Lanham \& Boulder \& New York \& Oxford: Lexington Books.

Egorov, Egor G. 2006. Sever Rossii: ekonomika, politika, nauka. [Russian North: Economy, Politics, Science.] Yakutsk: Sakhapoligrafizdat.

Estrin, Saul \& Aidis, Ruta \& Mickiewicz, Tomasz 2007. Institutions and Entrepreneurship Development in Russia: A Comparative Perspective. William Davidson Institute Working Paper Number 867, February 2007. Available at https://core. ac.uk/download/pdf/3119230.pdf, last accessed on 29 November 2018.

Gambold Miller, Liesl L. 2003. Interdependence in Rural Russia: The Postsocialist Mixed Feudal Economy. Max Planck Institute for Social Anthropology: Working Papers, No. 51. Halle/Saale: Max Planck Institute for Social Anthropology. Available at https://www.eth.mpg.de/cms/en/publications/working_papers/wp0051, last accessed on 26 November 2018.

Gibson, James L. 2001. Social Networks, Civil Society, and the Prospects for Consolidating Russia's Democratic Transition. American Journal of Political Sciences, Vol. 45, No. 1, pp. 51-68. http://dx.doi.org/10.2307/2669359.

Gustafson, Thane 1999. Capitalism Russian-Style. Cambridge \& New York: Cambridge University Press.

Hann, Chris M. 2000. The Tragedy of the Privates? Postsocialist Property Relations in Anthropological Perspective. Max Planck Institute for Social Anthropology Working Papers, No. 2. Available at https://estudiscritics.files.wordpress.com/2011/02/ chris_hann_postsocialismo1.pdf, last accessed on 23 November 2018.

Hedlund, Stefan 1999. Russia’s “Market” Economy: A Bad Case of Predatory Capitalism. London: UCL Press.

Hsu, Carolyn L. 2005. Capitalism Without Contracts versus Capitalists without Capitalism: Comparing the Influence of Chinese Guanxi and Russian Blat on Marketization. Communist and Post-Communist Studies, Vol. 38, No. 3, pp. 309-327. http://dx.doi.org/10.1016/j.postcomstud.2005.06.003.

Humphrey, Caroline 2000. An Anthropological View of Barter in Russia. In: Paul Seabright (ed.) The Vanishing Rouble: Barter Networks and Non-Monetary Transactions in Post-Soviet Societies. Cambridge \& New York: Cambridge University Press, pp. 71-92.

Humphrey, Caroline 2002. Rituals of Death as a Context for Understanding Personal Property in Socialist Mongolia. Journal of the Royal Anthropological Institute, Vol. 8, No. 1, pp. 65-87. https://doi.org/10.1111/1467-9655.00099.

Humphrey, Caroline 2012. Favors and "Normal Heroes": The Case of Postsocialist Higher Education. HAU: Journal of Ethnographic Theory, Vol. 2, No. 2, pp. 22-41. https:// doi.org/10.14318/hau2.2.003.

Köllner, Tobias 2013 [2012]. Practising Without Belonging? Entrepreneurship, Morality, and Religion in Contemporary Russia. Berlin \& Münster \& Wien \& Zürich \& London: LIT Verlag.

Krivoshapkin-Aiynga, Andrei 1998. Evraziiskii soiuz. [Eurasian Union.] Yakutsk: Bichik. 
Kuznetsov, Andrei \& Kuznetsova, Olga 2005. Business Culture in Modern Russia: Deterrents and Influences. Problems and Perspectives in Management, Vol. 3, No. 2, pp. 25-31. Available at https://businessperspectives.org/journals/problemsand-perspectives-in-management/issue-7, last accessed on 29 November 2018.

Lapparova, I. F. 2002. Sotsial'nye posledstviia promyshlennogo osvoeniia Iakutii v raionakh prozhivaniia korennykh malochislennykh narodov Severa (konets $50 \mathrm{kh}-$ 80e gg.). [Social Consequences of the Industrial Mastering in Yakutia in the Districts of Compact Settlement of Small Indigenous People of the North (End of the 50s-80s.] In: A. Kardashevskaia \& E. Vasil'eva \& I. Lapparova (eds.) Malochislennye etnosy severa Respubliki Sakha (Iakutiia) glazami molodykh uchenykh. Yakutsk: IPMNS SO RAN, pp. 15-20.

Ledeneva, Alena V. 1998. Russia's Economy of Favours: Blat, Networking and Informal Exchange. Cambridge: Cambridge University Press.

Ledeneva, Alena V. 2006. How Russia Really Works: The Informal Practices That Shaped Post-Soviet Politics and Business. Ithaca \& London: Cornell University Press.

Ledeneva, Alena 2008. Blat and Guanxi: Informal Practices in Russia and China. Comparative Studies in Society and History, Vol. 50, No. 1, pp. 118-144. http:// dx.doi.org/10.1017/S0010417508000078.

McCarthy, Daniel J. \& Puffer, Shelia M. \& Shekshnia, Stanislav V. 1993. The Resurgence of an Entrepreneurial Class in Russia. Journal of Management Inquiry, Vol. 2, No. 2, pp. 125-137. http://dx.doi.org/10.1177/105649269322002.

Nee, Victor \& Young, Frank W. 1991. Peasant Entrepreneurs in China's "Second Economy": An Institutional Analysis. Economic Development and Cultural Change, Vol. 39, No. 2, pp. 293-310. http://dx.doi.org/10.1086/451871.

Peng, Mike W. \& Shekshnia, Stanislav V. 2001. How Entrepreneurs Create Wealth in Transition Economies. The Academy of Management Executive, Vol. 15, No. 1, pp. 95-110. http://dx.doi.org/10.5465/ame.2001.4251397.

Pickles, John \& Smith, Adrian (eds.) 1998. Theorising Transition: The Political Economy of Post-Communist Transformations. London \& New York: Routledge.

Polischuk, Leonid 2001. Small Businesses in Russia: Institutional Environment. University of Maryland, Iris Working Paper No. 240. Available at https://papers.ssrn. com/sol3/papers.cfm?abstract_id=260042, last accessed on 26 November 2018.

Puffer, Sheila M. \& McCarthy, Daniel J. \& Boisot, Max 2010. Entrepreneurship in Russia and China: The Impact of Formal Institutional Voids. Entrepreneurship Theory and Practice, Vol. 34, No. 3, pp. 441-467. http://dx.doi.org/10.1111/j.15406520.2009.00353.x.

Radaev, Vadim 1998. Formirovanie novykh rossiiskikh rynkov: transaktsionnye izderzhki, formy kontrolia i delovaia etika. [Formation of Russian Markets: Transaction Costs, Forms of Control, and Business Ethics.] Moscow: Tsentr politicheskikh tekhnologii.

Radaev, Vadim 2005. Establishing Trust in a Distrustful Society: The Case of Russian Business. In: Hans-Hermann Höhmann \& Friederike Welter (eds.) Trust and Entrepreneurship: A West-East Perspective. Cheltenham, UK: Edward Elgar, pp. 114-135. 
Rasell, Michael 2009. Neoliberalism in the North: The Transformation of Social Policy in Russia's Northern Periphery. Polar Geography, Vol. 32, No. 3-4, pp. 91-109. http://dx.doi.org/10.1080/10889370903471292.

Sakaeva, Maria M. 2012. Parlament kak “okno vozmozhnostei': issledovanie povedeniia predprinimatelei s deputatskim mandatom $\mathrm{v}$ khode realizatsii rynochnykh interesov. [Parliament as a "Window of Opportunities".] Ekonomicheskaia sotsiologiia, Vol. 13, No. 3, pp. 96-122. Available at https://ecsoc.hse.ru/2012-13-3. html, last accessed on 30 November 2018.

Shlapentokh, Vladimir 2007. Contemporary Russia as a Feudal Society: A New Perspective on the Post-Soviet Era. New York, Houndmills: Palgrave Macmillan. DOI: 10.1057/9780230609693.

Ssorin-Chaikov, Nikolai 2000. Bear Skins and Macaroni: The Social Life of Things at the Margins of a Siberian State Collective. In: Paul Seabright (ed.) The Vanishing Rouble: Barter Networks and Non-Monetary Transactions in Post-Soviet Societies. Cambridge: Cambridge University Press, pp. 345-361.

Stark, David 1991. Path Dependence and Privatization Strategies in East Central Europe. East European Politics and Societies: and Cultures, Vol. 6, No. 1, pp. 1754. https://doi.org/10.1177\%2F0888325492006001003.

Stepanova, N. A. \& Nogovitsyn, R. R. 2011. Maloe predprinimatel'stvo Severnogo regiona $v$ usloviiakh perekhoda na innovatsionnyi put' razvitiia. [Small Businesses in the Northern Region during Transition to Innovative Development.] Yakutsk: Sfera.

Strickland, Michael 2010. Aid and Affect in the Friendships of Young Chinese Men. Journal of the Royal Anthropological Institute, Vol. 16, No. 1, pp. 102-118. http:// dx.doi.org/10.1111/j.1467-9655.2009.01599.x.

Tarasov, M. E. \& Egorov, E. G. \& Kulakovskii, G. P. 2013. Vliianie tenevoi ekonomiki na ekonomicheskuiu bezopasnost' regiona: monografiia. [The Impact of Shadow Economy on the Economic Security of the Region: Monograph.] Yakutsk: SeveroVostochnyi federal'nyi universitet.

Tyrylgin, Mikhail A. 2000. Istoki fenomenal'noi zhiznesposobnosti naroda Sakha. [Sources of Phenomenal Vitality of the Sakha.] Yakutsk: Bichik.

Ventsel, Aimar 2005. Reindeer, Rodina and Reciprocity: Kinship and Property Relations in a Siberian Village. Halle Studies in the Anthropology of Eurasia, Book 7. Berlin: LIT Verlag.

Verdery, Katherine 1993. Ethnic Relations, Economies of Shortage, and the Transition in Eastern Europe. In: Chris M. Hann (ed.) Socialism: Ideals, Ideologies, and Local Practice. London \& New York: Routledge, pp. 172-186.

Verdery, Katherine 1996. What Was Socialism, and What Comes Next? Princeton, New Jersey: Princeton University Press.

Wegren, Stephen K. 2000. Socioeconomic Transformation in Russia: Where Is the Rural Elite? Europe-Asia Studies, Vol. 52, No. 2, pp. 237-271. http://dx.doi. org/10.1080/09668130050006781. 


\title{
"I EXIST THEREFORE YOU EXIST, WE EXIST THEREFORE THEY EXIST": NARRATIVES OF MUTUALITY BETWEEN DEITIES (YUL-LHA GZHI BDAG) AND LHOPO (BHUTIA) VILLAGERS IN SIKKIM ${ }^{1}$
}

\author{
Kikee D. Bhutia \\ Doctoral student \\ Department of Estonian and Comparative Folklore \\ University of Tartu, Estonia \\ e-mail:keylabhutia@gmail.com
}

\begin{abstract}
This article engages with the presence, personalities, and lives of $y u l$ lha gzhi bdag (protective and guardian deities) who reside with the Lhopo (Bhutia) community in Sikkim, India. Informed by fieldwork, and through narratives, observations, and experiences, I illustrate and discuss how interactions and connections between villagers and deities are shaped by principles of relationality and mutuality. After discussing the various meanings and manifestations yul lha gzhi bdag take on in diverse Himalayan contexts, I illustrate through discussions of rituals, practices, beliefs, and narratives how the 'mundane' routines and lifeworld of the Lhopo villagers variously connect with, and derive meaning from, the supernatural world that surrounds them. I argue, however, that this is not a one-way process but that deities similarly rely on villagers to derive and validate their existence in the world. This mutuality, however, increasingly finds itself under strain as a result of social processes of modernity, globalization, changing relations with land, religious conversion, and competing forms of educational and medical knowledge, on which I reflect in the conclusion.
\end{abstract}

Keywords: Buddhism, everyday practices, mutuality of being, narratives, yul lha gzhi bdag (guardian deities)

\section{INTRODUCTION}

"If you put your hands into a beehive, it will hurt, right? Your research is like putting your hands into a beehive," a senior monk warned me after I had told him I wished to research the yul lha gzhi bdag (guardian deities). Among the Lhopos (Bhutias), guardian deities are many, manifold in character, and mired into often competing narratives. Anna Balikci (2008: 85), in her book Lamas, 
Shamans and Ancestors: Village Religion in Sikkim, wrote, based on her interviews with Lopen Dugyal, who happens to be my grandfather, that "there are many more spirits and deities inhabiting the environment in Sikkim than there are human beings".

This article ventures into this densely populated supernatural landscape to explore the relational practices and beliefs that connect these spirits and deities with villagers. I do so through the vantage of narratives, as they are told and re-told in the small Lhopo village of Tingchim in northern Sikkim. I begin by narrating a personal experience told to me by a villager (male, 52 years old, 2016) ${ }^{2}$ :

I went to pick Daw's aba-ama's [father and mother's] cardamom in their field. It is just there, near that little forest area [pointing with his finger]. It was not that long ago. Perhaps five or six years. I was picking cardamom near the stream. Our village was on the other side of the river. To my right was Zyashing Aju [the guardian deity who resides there]. While collecting cardamom and slowly shifting down the field, I inched closer to Zyashing Aju [Aju translates as "old man" or "grandfather"]. I noticed that the cardamom plants were very healthy in that area. Then I said bluntly: "Oh, today I have come near our neighbor Zyashing Aju, but it seems he does not even want to greet us?" I was not alone that day. Many other workers were there, and I said it in a joking manner. We all laughed. That night my waist was in terrible pain. Zyashing Aju shi-je [caught, attacked]. I had to perform a sdè chey [offering to the sdè ${ }^{3}$ to appease him. Only after that I returned to my normal self. This was how Zyashing Aju greeted me back.

My informant related the pain he felt in his waist immediately to his, somewhat mischievous, interference in the abode of Zyashing Aju earlier that day. He realized that his taunting, even if meant light-heartedly, had angered the deity into inflicting punishment. My informant knew that the only way for him to get cured now was to propitiate Zyashing Aju through a ritual offering. What this opening narrative illustrates is, among others, that yul lha gzhi bdag are an intricate part of village life - both in articulations (villagers addressing them) and acts (villagers propitiating them).

In Tingchim, and Lhopo villagers more widely, such personal narratives, experiences, and stories serve to actualize the supernatural world and therefore impact the way villagers perceive these worlds. Cristina Bacchilega (2015: 28) writes: 
Stories construct our worlds and us at the same time, emerging from actual negotiations with and in these worlds. Stories create and weave together the social networks that define us whether we belong to them or we other them. Stories shape our conceptions of these worlds, and they have material impact on these worlds, the human ones and the other living ones (natural and spiritual) we are a part of.

That stories help to construct the world around us, both mundane and supernatural, became evidently clear to me while I was conducting fieldwork and gathering belief narratives in 2016-2017. My aim was, first, to document circulating narratives of yul lha gzhi bdag, and, secondly, to understand the interaction and relationships that exist between these deities and villagers. Put differently, I wanted to explore how the everyday, mundane world of Tingchim villagers connects with, and is shaped by, the supernatural world surrounding them.

In what follows I apply belief narratives to describe and discuss the dyadic relationships that exist between deities and villagers. Oftentimes, I will illustrate, villagers portray a certain fear, or certainly apprehension, of offending deities, knowing that deities, once angered, can exert various forms of punishment, including sickness, insanity, and premature death. What I will argue here, however, is that deities inflicting such punishments may also be seen as communicative of deities' own fears of being forgotten by the villagers, their apprehension of not being acknowledged through offerings and sacrifices. These feelings of mutual fear, however, do not suggest relations of hostility and impending danger, but are reflective of - and herein lies the main argument of this article - the "mutuality of being" that is constitutive of the identities, indeed the very existence, of both deities and villagers. As a way of seeing kinship, Sahlins (2013: 18-20) describes the "mutuality of being" as the "participation in another's existence", as "conjoint being", and "interdependent existence". Transposing this argument to the relationships between deities and villagers, I will illustrate that they share a close interconnectedness and sense of shared existence and belonging.

\section{YUL LHA GZHI DAG: A BRIEF INTRODUCTION}

The phenomenon of yul lha gzhi bdag has been classified and theorized differently in different parts of the Himalayas, where their existence is widely reported. But one of the most accepted explanations remains that the yul lha gzhi bdag are the untamed deities of the land who were bounded into the oath by Guru Rinpoche, who is also known as the second Buddha in the eighth cen- 
tury. In Tibet, to start with, Réne de Nebesky-Wojkowitz (1993: 15) explains yul lha as "country gods" and gzhi bdag as "foundation owners", citing Giuseppe Tucci (1980 [1949]:

It appears that these classifications do not cover all the great variety of spirits, ghosts, demons, gods in which Tibetans believed. The character of these beings was in many cases so vague that it was very difficult to establish demarcation between them. Even the place they were supposed to dwell is not enough to establish a clear distinction between the various classes of gods: for lack of individuality these divine groups tended to blend together.

Samten G. Karmay (1998: 66), writing in the context of mountain deities in Tibet, translates yul lha as "deity of the local territory", and justifies this by translating $y u l$ as "local", citing terms such as yul-dpon (local chief), yul skad (local dialect), and $y u l ~ m i$ (local people) to his support. Valentina Punzi (2013: 73) similarly argues that the worship of yul lha gzhi bdag is best understood as "the cult of mountain dwelling local numina", and translates the term yul lha as the "deity of the local territory". Katia Buffetrille, in turn, translates yul lha as "Territorial God" (Buffetrille 1996: 6). Françoise Pommaret (2012: 4), in the context of Bhutan, highlights a certain vagueness surrounding this term. She, however, settles on the position of gzhi bdag as "master of the place", but reiterates how the relationship between a "dgra lha (mountain god) and a yul lha (territorial god) is quite blurry". She continues: "The whole issue of definitions is all the more complex today, as recent extensive fieldwork in the Himalayas has shown significant variations from region to region among deities referred to by the same generic term" (ibid.).

These classifications and explanations are derived from areas surrounding Sikkim, specifically from Tibet and Bhutan. I now discuss the meaning of $y u l$ lha gzhi bdag in the context of Sikkim, especially for the Lhopos (Bhutias). In the social context of Tingchim, and according to one of my informants (male, 72 years old, 2016), yul lha gzhi bdag must be distinguished into two categories: benevolent ye shes kyi lha (also known as sang gye kyi lha), and dangerous jig rten kyi lha. ${ }^{4}$ In simple terms, ye shes kyi lha refers to enlightened deities (lha) who belong to the Buddhist ritual. Among these ye shes kyi lha, Dzönga ${ }^{5}$, who resides on Mount Khanchendzönga, ${ }^{6}$ is considered as "a supra-worldly deity of the Buddhist pantheon (ye shes lha)" (Balikci 2008: 90).

One of the main characteristics of the ye shes kyi lha, as one of my interlocutors (male, 58 years old, 2016) explained, is: "They do not inflict sickness on people. They do not harm them. Instead they are Dharma protectors [protector 
of Buddhist doctrines and teachings] and were subdued by Guru Rinpoche himself." Most informants explained that Guru Rinpoche himself is a ye shes kyi lha.

Jig rten kyi lha, on the other hand, are considered as "unenlightened gods", or the gods of the temporal world (jig rten can translate as "worldly" or "lay people"). Contrary to ye shes kyi lha, these "unenlightened deities" are known and feared for inflicting sickness and misery when offended. Besides causing sickness, they, for instance, possess powers to disrupt rainfall, causing great loss to villagers as this affects the quality and quantity of harvests. This interpretation opens the possibility of $y u l$ meaning "worldly" or the god (deity) of the "lay people". One informant explained: "They cannot show us the path to enlightenment but they can determine our well-being and prosperity while we are in this world."

This separation of deities as either Dharma protectors or "worldly" relates, more deeply, to the advent of Buddhist teachings and philosophy in Sikkim. Most of the ritual specialists and monks in Sikkim argue that yul lha gzhi bdag were subdued by Guru Rinpoche around the eighth century when he visited Sikkim on his way to Tibet. This also seems the case in Bhutan and Tibet as it is believed that yul lha gzhi bdag were present in the land well before the arrival of Guru Rinpoche, but, on Guru Rinpoche's command, changed character and transformed into guardians and protectors of the land (Phuntsho 2013: 84). In exploring the past and presence of the yul lha gzhi bdag, and their relationship with human beings, I draw significantly on belief narratives and personal experiences as told by villagers.

\section{YUL LHA GZHI BDAG AND THE "BUDDHIST TURN"}

As I inquired into the relationship between deities and the arrival of Buddhism, one of my informants (male, 61 years old, 2017) said:

In Denjong we had numerous sdé and simu [malevolent spirits]. When Guru Rinpoche came, he not only subdued them but also bound them into an oath, turning them into protectors of the land. He purified the land and made it a sacred Buddhist place and made them the daku [owner, keeper, master].

Most of my informants portrayed a collective memory of the yul lha gzhi bdag being present in the land long before the advent of Buddhism. One of them (male, 58 years old, 2016) explained: "Yul lha gzhi bdag are neither Bon nor Buddhist. I exist therefore you exist; we exist therefore they exist. They exist just as we [humans] exist." Another informant (male, 72 years old, 2017) added: "We have 
been offering to them for a long time. Even before your great-great-grandfather was born, and even before we had any monks and monasteries in the village."

With reference to the advent of Buddhism in Tingchim, Anna Balikci (2008: 56) writes that Tingchim villagers received the first major Buddhist influence that present villagers can remember from the Lachen Gomchen (Rinpoche). ${ }^{7}$ She continues:

From his retreat above Tingchim, he is said to have prevented pawo's and nejum's [shamans] from being born in all the surrounding villages. He told villagers that with their drums and bells, the pawo and nejum kept waking up the nöpa, the ambiguous supernatural beings of the locality who could otherwise sleep for many decades if left undisturbed.

In Tingchim, villagers mostly remember the pre-Buddhist presence of the $y u l$ lha gzhi bdag by invoking narratives of baitsi natsi (annual offerings). ${ }^{8}$ What their narratives variously emphasize is the integration of pre-existent deities into the practices and beliefs of everyday Buddhism. The advent of Buddhism reshaped stories, narratives, rituals, and, as we have seen, the roles of the deities.

After the arrival of Buddhism, the way villagers interpreted and engaged deities started to change first through the kinds of offerings and rituals that were performed. I remember my mother falling seriously ill. After a divination by a (non-Buddhist) shaman, a black hen was killed as an offering, and later became our dinner. Just a few years later, however, such 'blood sacrifices' largely vanished and were replaced by the offering of bones. In fact, while having dinner, we were not allowed to throw away any bones but had to collect them for such occasions. Offerings thus changed from animals to their bones. One villager (male, 52 years old, 2016) explained: "Earlier we offered them ribs and the hind leg of an ox, but later, and because I am a monk now, I offer 'dyõe' (red thread)." Presently, most rituals are no longer performed by shamans but by village monks to the extent that some of the new shamans do not get possessed; neither are they hereditary as it used to be but now they are hired or chosen collectively by the village elders to perform the duties of the shamans and Bongthing (in special cases with Lachung, North Sikkim). Instead of animal sacrifice, rituals of tshi tha (in which the animal is either set free in the wild or domesticated not to be killed or sold) is practiced, which can be seen as an element of Buddhist influence. It was the Buddhist philosophy of compassion that resulted in this conversion from animal sacrifices to offerings of sur (milk, rice, and incense). This shift can be read as a transfer of authority of the ritual performers, in this case from pawo and nejum to Buddhist monks and village elders. 
Today, not only are pawos and nejums declining in numbers, but potential new shamans often go unrecognized. Recently, a girl in Tingchim showed signs of possession but the possibility of recognizing her as nejum was difficult for two reasons. Firstly, there were no elders and experienced pawos in the vicinity to recognize and train her. Secondly, she herself sought help and explanation from a Christian neighbor in the village, who interpreted her condition in terms of devil possession. This sparked anger among the villagers, resulting in her family's ex-communication from village activities.

Regarding the relationship between Buddhism and local deities, one of my interlocutors (male, 68 years old, 2017) narrated:

There are two kinds of yul lha gzhi bdag. Those who were there from the start and those recently arrived [transformed]. They are non-human and we are human. But just as we work during the day to take care of our families and do household chores, yul lha gzhi bdag do the same at night. They too have families to take care of. These are the first type of yul lha gzhi bdag. The other type of yul lha gzhi bdag are new arrivals, or those who changed character over time. They became gzhi bdag because of bad death, especially monks who were murdered. But there are other differences. You and I cannot become gzhi bdag even if we are murdered. ${ }^{9}$ Those who became gzhi bdag were learned and powerful as they had knowledge of ritual texts and the power to influence people through their knowledge. They are not shamans but monks and learned men.

He continued:

Let me tell you a story of how, in Gelugpa, ${ }^{10}$ during the reign of the Fifth Dalai Lama in Tibet, there was a monk who achieved the pinnacle of knowledge. He was considered as very learned, even equaling Dalai Lama himself. Because of his knowledge it became feared that he might challenge the authority. He was subsequently strangled, with a khata ${ }^{11}$ being stuffed into his mouth. He was murdered [by the government]. Have you heard of this from anyone? You should have. Everybody knows. Because he was treated unjustly, he was very upset and while he was being killed, he prayed to be reborn as sdé. Soon after, he was indeed reborn in the realm of sdé, and began harming monasteries and cause havoc. No one could do anything to stop him. Not even the Fifth Dalai Lama himself. So finally, to appease him, they performed a ritual, invoked his spirit, and negotiated with an annual offering. Till today, Gelugpa(s) must offer annually and I tell you, it is not easy to get rid of them [deities]. ${ }^{12}$ 
In this section, I argued that in Tingchim village, yul lha gzhi bdag are perceived as non-human entities that resided in the village well before the advent of Buddhism. Their existence, status, and relationships with human entities, however, altered with the arrival of Buddhism. What changed, too, was the way villagers approached them and made offerings to them. Earlier shamans possessed complete authority over rituals. Shamans were powerful and made offerings in ways prescribed by tradition, which included possessions, trance, and animal sacrifices. Today, however, it is no longer shamans but predominantly monks who preside over rituals. Thus, this change in the authority over tradition led to Buddhist practices, principles, and scriptural knowledge, which resulted in the incorporation of Buddhist views into the world of yul lha gzhi bdag, transforming the status of the deities as well as their relationship with the villagers.

\section{RELATEDNESS AND MUTUALITY}

In this section, I discuss and illustrate the relational principles that connect Tingchim villagers and yul lha ghi bdag by framing their relations in an idiom of "relatedness" (Carsten 2000). I discuss what "being related" to the supernatural means for villagers, and explore the "implications and lived experience of the relatedness" (Carsten 2000: 2). One such implication is the villagers' and deities' "mutuality of being", in the sense that they "participate intrinsically in each other's existence" (Sahlins 2011: 1).

Tingchim villagers' conceptions of personhood, or "the self", cannot be disentangled from the presence of deities in their lives. In fact, in referring to deities, villagers frame them as kin and may call them aju (grandfather) or ana (grandmother). These are respectful terms, and indicate simultaneously familial intimacy and the elevated positions deities occupy in the social hierarchy of the village. But deities are not kin only in terms of kinship terminology. They are also believed to reside inside houses and with the families they belong to. Their presence offers village households a sense of security and protection.

To illustrate this further, I now turn to three different kinds of deities that, according to villagers, reside in and around the village, and discuss their specific relations to the villagers. The first kind are those that reside in nature in or around the village, in places like particular trees, streams, lakes, and fields. Secondly, there are deities that reside in houses, mostly in attics, basements, altars, or around the hearth. The third kind of deities may be typified as "personalized deities" as they attach themselves to particular individuals, and move along with them. 
"Nature deities" appear in many stories. One villager (female, 54 years old, 2016) narrated to me the following story (which is commonly told in the village):

Out there [pointing to the right from where we were sitting], is Kedo Gong [name of place]. Do you see those trees? These trees are kin to the tsomen who lives in the stream nearby. We don't want to touch anything near that place. In the past, there was a villager who cut a tree from there. Oh wait, let me think. Who was it? It was not that long ago. It was during my grandfather's time. It must have been Gochung Aju. But I am not sure whether it was aju or aju lala. I think it is aju la la (great-grandfather). Me: What is tsomen?

Tsomen is a small stream. Tsomen is also gzhi bdag, but a bad and dangerous one. Pregnant women should never go near it. If they do, the tsomen may eat up the child inside the womb, right then and there.

One day Gochung Aju went to Kedo Gong and cut a tree. The moment he brought it home, his daughter-in-law fell ill. Within a week, she died. While she was sick, a nejum [shaman] was brought home to diagnose her. She was a very powerful nejum. The nejum got possessed, and through her the tsomen spoke: "You cut my daughter-in-law, so now I am taking yours."

Tsomen evidently is a very fierce deity. But not all deities are. Another villager (male, 27 years old, 2017) narrated:

I am in timber business. In this I need to be careful as deities reside in the forest and protect these trees. They also protect us. I therefore make offerings before I cut any tree. I need to do this to protect myself, as well as those working for me. If I just cut trees, without asking the deities' permissions, they will get upset. As long as I make offerings to them, they will keep me safe. In the past, it was my grandfather's duty to appease the deities, but when I inherited the land, I inherited the deities too, and now it is my task to make offerings to them.

One day, while I was away from the village, I told my contractor to go ahead with the work. Suddenly the weather turned very bad and a thunderstorm obstructed our work. I immediately returned to the village, sensing that something was wrong. I offered sur $^{13}$ and told the deities: "Thank you so much for providing me with these precious trees. Thank you for your protection. Now I request you to protect me and my men while we cut them." Within a few minutes, the thunderstorm stopped and my men could continue their work.

These two narratives exemplify the close bonds that exist between villagers and deities. Relations between them revolve around protection and respect, but also 
revenge. The idea of revenge, as shown in the first narrative, can be compared to human emotions, thus suggesting that deities have emotional dispositions similar to humans. The second narrative shows how deities, like humankind, are traced across generations. A villager, thus, is not just related to his or her immediate father and mother, but also, by extension, to their deities, as these follow similar patterns of descent. In both narratives, the medium of offerings nourishes and connects villagers and deities.

Regarding the "house deities", villagers oftentimes invoke Palo Ana" (attic grandmother). Palo Ana refers to a guardian deity who resides in almost every village attic and is looked upon as the protector of the house, and a repository of its wealth and health. She, however, can also be demanding and vengeful, and she is feared for her powers to inflict sickness and bestow misfortune on family members who disrespect them, or do not make offerings in time. I asked a village elder (male, 68 years old, 2017), who is known as a healer, what Palo Ana was and why we kept her. He replied:

At some point I also wondered about it and asked my father. I remember being angry, telling my father: "We are already so poor, ${ }^{15}$ why must we feed a deity when we cannot even feed ourselves?" My father replied: "It is not by choice. Our forefathers were friends with Lepchas ${ }^{16}$." One day they planned to build a döh [a shed that people build in the wild to keep their animals] and keep all their cattle in the wild together, both Lepchas and Bhutias. But our ancestors Lhopos were cunning, and when the Lepchas wanted to discontinue the venture, they took the best cows and the strongest bulls and left the weak and old ones to the Lepchas. The Lepchas did not say anything, but inside they were deeply upset. They then told their deities that they had nothing to offer them any more as the best cattle had been taken away and that they would therefore best follow the Lhopos. Soon, our people started defecating blood and falling sick. Upon this, the Lhopos invited the pawo. The deities told him: "Our guardians told us to go. They told us that all their wealth was taken away, and that they have nothing to offer us. They told us not to let you live in peace." Over the years, we tried many times to get rid of the deities but this was never possible. Eventually, we decided to negotiate with them. The deities told us: "We need a place to stay and annual offerings. If you give us both we will not harm you, but instead offer our protection.”

This narrative shows, among others, the historical possibility of "transferring deities" from one community to another. It also communicates the sway villagers can have over the deities, as the deities adhered to the Lepchas' demand that they leave and follow the Lhopos. 
Finally, I present what can be called "personalized deities", particularly those deities that are considered as attached to women in the village. About one such deity, a village woman (56 years old, 2017) said:

Well, when Daw Ama [villager's sister-in-law] falls ill or suffers for longer than three days, and so without any known cause, we request the pawo or nejum to perform mõh [divination]. In most cases, this tells us that she is inflicted by her maternal deity [lha], in which case she has to go back to her maternal house to make an offering.

When I prompted and asked why Daw Ama had to go back to her maternal house, I was told:

It has never occurred in the village that one could make the offering in any other place but her maternal home. It is there where the deity resides. We can't offer to the deity anywhere else but where they reside.

She then added:

In my case too. If I fall sick and I find out that the cause is the household deity residing in my maternal house, my brother would make an offering in his house, as the makhim [the main house / house where your ancestors lived] is now passed down to him, so the duty of making the offering has passed down to him as well.

While this narrative indicates that offerings can be made either by the afflicted person herself or by a family member, they show that in both cases the offering has to be made in the maternal home, as it is here that the deity resides. As such, villagers share with their deities a clear connection of "place" and "belonging", and it transcends the patrilocal residence patterns followed by villagers. Another informant (female, 65 years old, 2017) told me:

When a woman is married off, she will usually carry with her the lha sung [a deity who protects and moves with the individual] from her maternal house [Azang khim], who will follow her to the house of her husband. She will protect and bless her, provided, of course, that she will not be careless in making offerings.

Lha sungs, however, do not follow brides in all cases, or at least not so in contemporary times. Villagers ascribe this change to "modern times". In these so-called "modern times" village girls increasingly marry in far-away cities and subsequently return to their natal village only intermittently. And rather than consulting a shaman when they fall sick, they consult doctors in a modern hospital. In doing so, they threaten the existence of deities. 
These various narratives illustrate the intimacy between human and nonhuman entities within the cosmology of Tingchim villagers. It highlights the close-knit relationships that exist between them; a relationship expressed through engagements with place and belonging.

To conclude this section, I end with a reflection of a villager (male, 72 years old, 2017):

Deities are like us humans. When they get angry they will come to fight with you. They are strong, and if you get angry and fight with them, you are sure to lose. Instead, in such a case, you need to be submissive and ask forgiveness. This will cool their tempers. Once you know how to treat them well, they will do you no harm and that we monks know very well.

\section{NARRATIVES ABOUT CHANGING CONTINUITIES}

In recent years, Tingchim village, and North Sikkim more widely, has changed significantly. Overall material development has resulted in a decreasing number of villagers today being engaged permanently in agriculture. Many villagers now work in the government sector, or have moved away from the village for purposes of education and employment. Consequently, most of the lands in the village's outskirts have been given in ädiya (lease) to immigrant Nepalese settlers. As today fewer villagers work in the fields, the fear of a bad harvest is more unfounded. It is worth asking whether this diminishing role of agriculture also correlates with the diminishing importance of deities more generally.

Another fundamental change is the arrival, and increasing popularity, of modern hospitals and medicine, resulting in villagers no longer primarily relating their afflictions to strained relations with deities. A village elder (male, 68 years old, 2017) narrated:

These days everyone believes in doctors. They don't want to take care of deities any longer. It is because villagers now avoid and ignore deities that we have not received proper rainfall for several years. It is also because of this that we are today inflicted with many diseases such as cancer. We are turning more sinful, and nowadays many villagers cheat and no longer think about dharma [good actions]. I remember Tshamkhang Aju ${ }^{17}$ telling me 'Lushey kyap lo, lushey kyap' [offer to the deities] when my daughter was suffering from severe pain in her feet. But most villages no longer think this way. 
Our deities provide us with food, clothes, and our other needs. Everything is in their hands. If they get angry, we will all fall sick and become poor. We need to offer to them. Of course, many in the village still do, but their intentions have somewhat changed. They are no longer pure in their offerings. Imagine, I place food for you on this table, but it is only when I say that it is meant for you that you will eat. This is the way villagers offer nowadays, they offer things but don't tell their deities to come and take it.

For this village elder, recent misfortune in the village is directly related to the villagers' declining consideration of their deities. For him, the villagers' denial and inability to perform rituals and offerings is the reason for all the problems befalling the village.

I also interviewed a villager (male, 56 years old, 2016) who had recently converted to Christianity, ${ }^{18}$ and asked him about guardian deities. His response was:

They are the fallen angels like Lucifer. They exist, they live among us, but we just don't acknowledge them and by doing that, whatever they do is ineffective for us. They cannot harm us because we do not believe in them.

In this case, a Christian convert consciously disowns yul-lha gzhi bdag, banishes them from his kinship network, and claims not to acknowledge them as they think their Christian beliefs are much stronger in keeping them at bay. Might this entail the death of yul-lha gzhi bdag, or, as the village elder was concerned, it only sets the stage for further misfortune to befall on the village?

\section{CONCLUSION}

This article began by discussing the diverse interpretations of the term yul tha gzhi bdag in the Himalayan region. I showed how this term has been understood differently in different places, followed by dwelling on the meaning of this term in the context of the Lhopos in North Sikkim, as well as on the "relatedness" and "mutuality of being" that connect villagers and deities. The focus here is on the narratives, on how through the stories and experiences the deities change their positions in the lives of the villagers. While collecting these narratives, I understood the emotions and beliefs of villagers retelling these stories, and discovered that the deities not only live in these lands but they are also immortalized through the story world. These stories are told not only to keep the villagers informed about the deities but often used as a "warning" against impending danger and as guides of how to propitiate and maintain a mutual relationship for mutual co-existence. 
Reflecting on the dangers that I was often warned about, I rather feel protected and supported by the yul lha gzhi bdag. The fieldwork rekindled my relationship with the deities and made me more aware that the deities are rather someone to be taken care of than something to be scared of.

\section{ACKNOWLEDGEMENTS}

This research was supported by the Dora Plus sub-activity 1.2, which is funded by the European Regional Development Fund and implemented by Archimedes Foundation. I would like to express my gratitude to Lachung and Tingchim families for extending their knowledge to me. I further thank Ülo Valk, Valentina Punzi, Aiela Anna Balikci Denjongpa, Jelle Wouters, and Perla Kværne for reviewing the article and for the additional comments. I would like to dedicate this article to Dawa Gyalpo Bhutia (2 August 1990 - 1 May 2018), without whom it would have been impossible to complete it.

\section{NOTES}

1 Winner of the ISFNR BNN 2018 Student Prize.

${ }^{2}$ Hereinafter all the informants are anonymous on request.

3 Sdé is a local term, which roughly translates as a spirit, demon, or ghost. However, it also refers to the occurrence in which a protective deity transforms into a destroyer. In such instance, an offering is needed to appease the deity into returning to its 'protecting state'.

4 There is, however, no uniformity about this amongst villagers, as I will discuss further below.

5 Dzönga is the name of the deity who is believed to be residing in Mount Khanchendzönga. He is often considered as the master or king of all other deities and subdued by Guru Rinpoche himself.

6 This mountain tallies as the third highest mountain in the world, after Mount Everest and Kakakoram (K2).

7 Lachen Rinpoche (1867-1947) was the first Rinpoche reincarnation from the place called Namok, which is the neighboring village to Tingchim. Lachen Rinpoche spent a long time in meditation in the areas around Tingchim.

8 Sikkim was considered as Buddhist Kingdom for 333 years but in Tingchim the influence of Buddhism only started in practice after the visit of Karmapa in 1910, when he altered the animal sacrifice with flour and incense. 
9 Although some of my informants also mentioned that ordinary people would turn into shen sdé - the spirits of a human turned evil after death. For example, one day I suffered from a severe headache. Upon consulting a shaman in the village, it turned out I was inflicted by the spirit of my uncle who had died a year before of a brain tumor. The difference between sdé and shen sdé is very thin. Sdé are considered as the deities who are malevolent and want to harm, but shen sdé are usually the spirits of the village (although sometimes can also be unknown) who inflict sickness. At times, if you eat in the wild, without offering the food to the shen sdé you might get stomach ache and start vomiting.

10 There are four denominations in Buddhism - Gelugpa, Kagyupa, Nyingmapa, and Shamarpa. Gelugpa tradition is the latest among the four main schools of Tibetan Buddhism, headed by His Holiness the Dalai Lama, who is known as the spiritual and temporal King of Tibet.

${ }^{11}$ A white silk scarf usually offered during weddings, celebrations, and funerals.

12 The above-mentioned story is about the assassination of Dorjee Shugden. For reference to Dorjee Shugden, please see "The Shuk-den Affairs: History and Nature of a Quarrel" by Georges Dreyfus (1999: 227-270).

${ }^{13}$ Sur-offering includes incense, butter, and rice flour.

${ }^{14}$ According to Anna Balikci (2008: 104), "Ship Anyo Pende and Gabar Pende are Lepcha grandmother spirits who live in the attics of the houses in Tingchim from where they protect the household"; in day-to-day conversation they are called Palo ana.

${ }^{15}$ One of the main reasons why villagers want to get rid of offering rituals is that they consider it very expensive, especially during the period when the harvest is not good. They have to invite the shaman, offer him food and accommodation; other people join him and they also have to be fed; in addition, there are expenses incurred for the arrangement of the ritual ingredients, which often include an animal, alcohol, etc.

${ }^{16}$ Lepchas (Rongs) are known as the 'original inhabitants' of Sikkim, whose migration is yet unknown and they oftentimes consider themselves as 'animists or nature worshippers'.

17 Tshamkhang Aju was a sesongpa - a person with the power to stop rain and hailstones, a lama who controls hailstones and rain. Sesongpas often even act as healers and doctors in the village.

${ }^{18}$ Kalu Bhutia (55 years old) was converted to Christianity on October 24, 1989. But because he settled in the town of Gangtok and merely visited the village, he had less influence on the community. Later converts included Pintso Bhutia (56 years old), who was converted on August 15, 1999, and still resides in the village. 


\section{REFERENCES}

Bacchilega, Cristina 2015. Narrative Cultures, Situated Story Webs, and the Politics of Relation. Narrative Culture, Vol. 2, No. 1, pp. 27-46. Available at https://digitalcommons.wayne.edu/narrative/vol2/iss1/, last accessed on 10 December 2018.

Balikci, Anna 2008. Lamas, Shamans and Ancestors: Village Religion in Sikkim. Leiden: Brill Academic Publishers. https://doi.org/10.1163/ej.9789004167063.i-406.

Buffetrille, Katie 1996. One Day the Mountains Will Go Away...: Preliminary Remarks on the Flying Mountains of Tibet. In: A. Blondeau \& E. Steinkellner (eds.) Reflections of the Mountain: Essays on the History and the Social Meaning of the Mountain Cult in Tibet and the Himalaya. Wien: Verlag der Österreichischen Akademie der Wissenschaften, pp. 77-90.

Carsten, Janet (ed.) 2000. Cultures of Relatedness: New Approaches to the Study of Kinship. Cambridge: Cambridge University Press.

Dreyfus, Georges 1998. The Shuk-den Affair: History and Nature of a Quarrel. Journal of the International Association of Buddhist Studies, Vol. 21, No. 2, pp. 227270. Available at https://journals.ub.uni-heidelberg.de/index.php/jiabs/article/ view/8876/2783, last accessed on 18 March 2019.

Karmay, Samten G. 1998.The Arrow and the Spindle: Studies in History, Myths, Rituals, and Beliefs in Tibet. Kathmandu: Mandala.

Nebesky-Wojkowitz, Réne de 1993. Oracles and Demons of Tibet: The Cult and Iconography of the Tibetan Protective Deities. New Delhi: Book Faith India.

Punzi, Valentina 2013. Physical, Cultural and Religious Space in A myes bar dbon: Written and Oral Traditions of a gnas ri in Amdo. Revue d'Etudes Tibétaines, Vol. 26, pp. 93-114. Available at http://www.academia.edu/3684160/, last accessed on 10 December 2018.

Pommaret, Françoise 2012. On Local and Mountain Deities in Bhutan. Available at https://halshs.archives-ouvertes.fr/halshs-00717941/document, last accessed on 10 December 2018.

Phuntsho, Karma 2013. The History of Bhutan. New Delhi: Random House.

Sahlins, Marshall 2011. What Kinship Is (part one). Journal of the Royal Anthropological Institute, Vol. 17, No. 1, pp. 2-19. https://doi.org/10.1111/j.1467-9655.2010.01666.x.

Sahlins, Marshall 2013. What Kinship Is... And Is Not. Chicago: Chicago University Press.

Tucci, Giuseppe 1980 [1949]. Tibetan Painted Scrolls. Kyoto: Rinsen Co. 


\title{
NEWS IN BRIEF
}

\section{INTERNATIONAL CONFERENCE ON BELIEF NARRATIVES IN FOLKLORE STUDIES: NARRATING THE SUPERNATURAL}

\author{
Guwahati, India, 6-8 February 2019
}

This year's BNN conference was organised by Anundoram Borooah Institute of Language, Art and Culture (Assam), with Dilip Kumar Kalita in front, and the Belief Narrative Network of the International Society for Folk Narrative Research, in the city of Guwahati, Assam, India. The conference was dedicated to the memory of two recently deceased prominent Indian folklorists: Professor Praphulladatta Goswami and Dr Promod Chandra Bhattachary.

The conference focused on the belief narrative in which traditional folk beliefs in the supernatural are given shape (and often credence) in popular narratives that (in the past) tended to be passed on in oral form. They are nonetheless not limited to the sphere of the folk legend, but can also result in new forms of behaviour, such as rumour-spreading, prejudice, witch-hunts and/or activities (even sacrifices), even in short folklore forms such as riddles and proverbs, designed to protect people from the influences in question, even in our own time. This conference aimed to give researchers the opportunity to share, discuss, and engage with a range of aspects related to the nature and role of belief narratives past and present.

Within three days, the conference had nine sessions with subtopics: Beliefs and the Supernatural; Beliefs and the Lore of Saints; Beliefs and Witch Hunting; Contemporary Belief Narratives (urban legends, the play on belief narratives by politicians, and so on); Beliefs and Vernacular Practices; Beliefs, Faith and Fear; Beliefs and Sacrifice. Altogether there were 74 presentations; half of them came from India, including many prominent students who focused mainly on different belief practices.

The session on beliefs and the supernatural discussed supernatural punishments, belief and disbelief, children's supernatural beliefs, the role of healers, ghosts, superpowers in folktales, and vernacular knowledge. The session on beliefs and the lore of saints dwelt upon the dimensions of Buddhism, godly spirits, saints, architectural places connected with beliefs, transformations into wild animals, and weather beliefs, while the session on beliefs and witch hunting focused on exorcism, witch phenomenon, and persecutions. The session on contemporary belief narratives was most diverse: the topics ranged from Mesopotamian myths and narrating supernatural to fake news with vampirism, Muslim martyrs in modern media, belief narratives among dancers and musicians, and functions of memorates on a local level. There were many different vivid presentations on contemporary belief narratives in local areas. The session on beliefs and vernacular practices discussed healing practices, riddles, symbolic meanings, and taboos, while the sessions on beliefs, faith, and fear, and that on beliefs and sacrifices focused more on local Indian phenomena and rituals. 


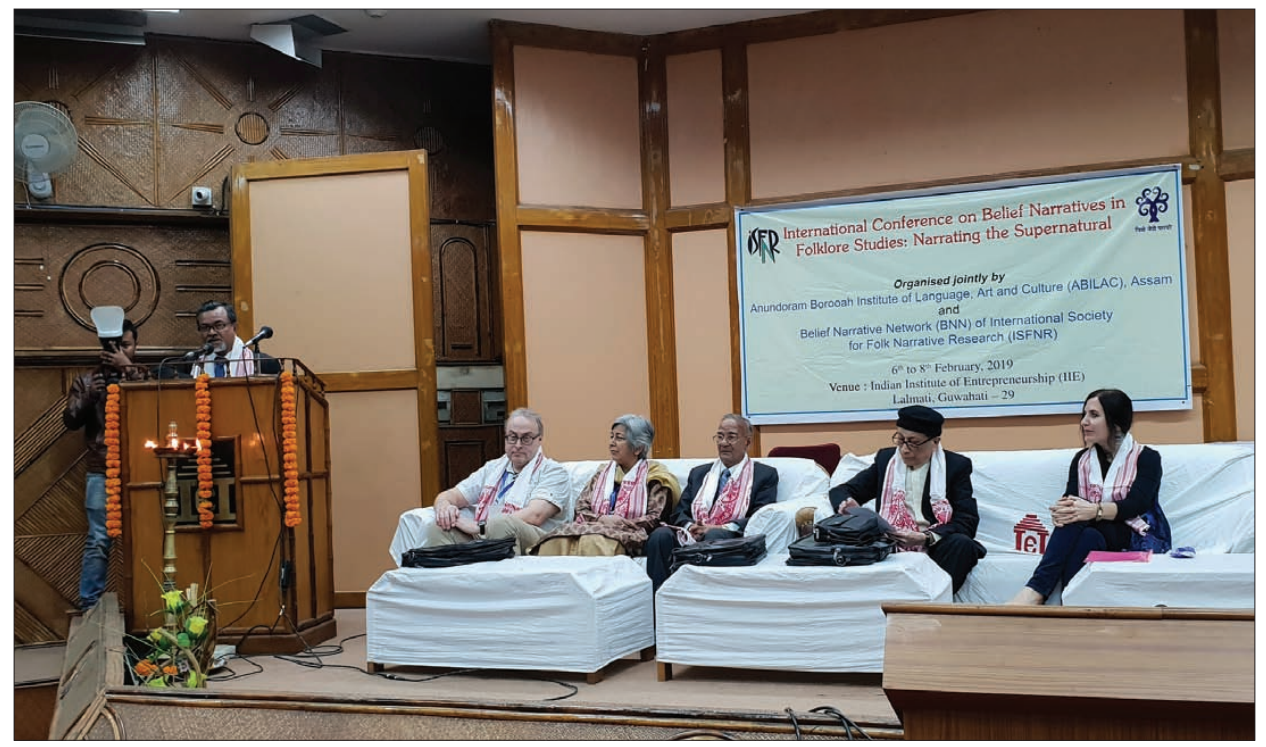

Inauguration ceremony of the ISFNR Belief Narrative Network (BNN) Conference in the Indian Institute of Enterpreneurship, Guwahati. Opening speech by the organising secretary Professor Dilip Kumar Kalita. Photograph Piret Voolaid 2019.

During the conference the 2018 student prize for the best paper in belief narratives was awarded to Kikee D Bhutia (India) for her paper titled "I Exist Therefore You Exist, We Exist Therefore They Exist": Narratives of Mutuality between Deities (yul lha gzhi bdag) and lhopo (Bhutia) Villagers in Sikkim.

Guwahati welcomed the conference participants with the beginning of spring flow and kind temperatures. The hosts treated the conference participants to delicious food and drink and an excellent cultural programme, presenting different Indian dances and music on both evenings.

Saša Babič 


\title{
BOOK REVIEW
}

\section{GILGAMESH AS CALENDRIC YEAR}

\author{
Vladimir Emelianov 2015. Gil'gamesh: Biografiia legendy. \\ Moscow: Molodaia gvardiia. 358 pp. In Russian.
}

In 2015 Vladimir Emelianov published a book on the Gilgamesh legend ${ }^{1}$ in the very famous Russian book series $Z$ hizn Zamechatelnyh Lyudei (The Lives of Outstanding People).

In the cultural legacy of the ancient Near East there are several legendary kings and heroes but probably the most famous among them was Gilgamesh, heroic ruler of the 1st Uruk dynasty (ca. 27th century BC). We have no firm evidence that he was even a real historical figure but he is a key character in several Sumerian epic songs and the main character of the Akkadian Gilgamesh epic. He was granted

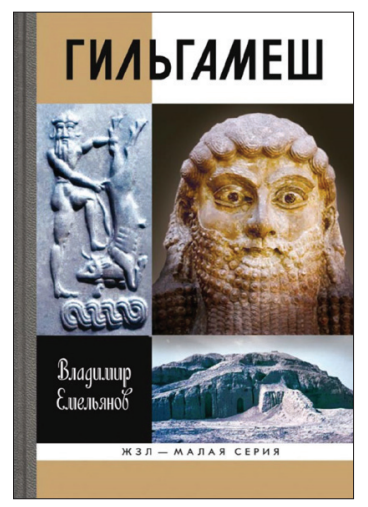
divine status posthumously and was worshipped for many centuries in the ancient Near East. Undoubtedly, the figure of Gilgamesh played a very important role in the Sumerian-Akkadian civilization and beyond: in cults, in royal ideology and in literary legacy. Sumerian epic songs about Gilgamesh, written ca 2100-2000 BC, were probably the most popular literary works in the Mesopotamian cultural space from the late 3rd to the 1st millennium BC. In the second millennium $\mathrm{BC}$, based on several of these short Sumerian epic songs (Gilgamesh and Akka, The Death of Gilgamesh, Gilgamesh, Enkidu and the Netherworld, etc.), the famous Epic of Gilgamesh was written in the Akkadian language. ${ }^{2}$

Emelianov's book Gil'gamesh: Biografiia legendy (Gilgamesh: Biography of the Legend) is a comprehensive and solid monograph on Gilgamesh and his role in ancient Near Eastern history, his religion, ideology, literature, and his cultural legacy from ancient times until the modern day. The most significant and innovative contribution of this author in the field of Ancient Near Eastern studies is the idea or concept of Gilgamesh and calendrical time ${ }^{3}$ where, amongst other things, he showed that in the Early Dynastic period the Sumerian Bilgames cult was connected with the important autumnal festival of Bau. In Nippur, during the Ur III period, Bilgames was seen as a hero of the 5th month and sporting games. Much later, in the Neo-Assyrian version of this Akkadian epic, all 12 months of the Nippur-Babylonian year and calendar belonged to Gilgamesh. Gilgamesh thus became a man-year. According to Vladimir Emelianov, in the Epic of Gilgamesh we see the calendar being anthropomorphised and this crucial phenomenon was connected with the great scholar Nabû-zuqup-kēnu. ${ }^{4}$ Additionally, Emelianov points out parallels between the 12 tablets of the Akkadian Epic of Gilgamesh and the 12 phases of the life of Buddha. He shows that this construct of life, consisting of 12 parts, is an idea which originated from the Axial Age. The author also focuses on several other important issues related to the Gilgamesh epic, for example, Gilgamesh 
as a historical person, the development of the Gilgamesh cult, connections between Gilgamesh's genealogy and Gudea as cause for the deification of Gudea, etc.

The book is divided into three chapters and contains a conclusion, appendices, and a bibliography as well as extensive notes.

The first part of the book, "Bilgames, en of Uruk" (pp. 12-105), provides a profound overview of the Sumerian Bilgames, some historical background, and puts all known sources of Bilgames/Gilgamesh under the microscope. It begins with an introductory chapter on Unug (Uruk) (pp. 12-27), in which the author gives a historical overview of the ancient Sumerian city of Uruk and its role in Mesopotamia. In the second chapter, "Bilgames in History" (pp. 27-48), the author discusses several questions related to the role of the Sumerian Bilgames in history, and makes several interesting observations on the appearance of the name Pabilga, Bilga, Bilga- $d u_{10}$ in Sumerian sources. Based on this analysis, the author comes to the conclusion that Bilgames lived no later than in the 27th century BC and had already been deified very early in Early Dynastic times (pp. 29-30).

The very interesting topic of the deification of the Sumerian Bilgames (Akkadian Gilgamesh) is discussed by Vladimir Emelianov richly and deeply. In this book he makes several crucial observations (e.g., p. 33):

In royal inscriptions from the Old Sumerian period and in inscriptions of Akkad, Bilgames is never mentioned. From this we can draw certain conclusions about the secundarity of his cult at the time when these inscriptions were composed (25th-23rd centuries BC). The deity who was connected with burial tombs and cemeteries was hardly able to provide military might to the rulers of the I dynasty of Lagash. This deity (Bilgames) was able to inspire the soldiers to win or to die heroic deaths in battle (as testified by inscriptions at the top of their maces), but was hardly able to make the ruler "king of the four corners".

Emelianov rightly shows that the Bilgames cult only began to flourish in the SumerianAkkadian world during the second Lagash dynasty (pp. 33-34), and I agree to such argumentation. He makes an interesting observation about Bilgames' connection to Gudea of Lagash. According to the Gudea royal inscriptions, Gudea liked to compare himself to the divine hero Gilgameš ${ }^{5}$ (Bilgames), anticipating the later Neo-Sumerian (Ur III) ${ }^{6}$ king Šulgi (2093-2046 BC). ${ }^{7}$ Emelianov also rightly remarks (p. 34) that Gudea was referred to in his own text as "god of his city", "son of Ninsun" (Bilgames was also Ninsun's son). For example, on Cylinder B, Gudea uses the very interesting epithet "ensi (city ruler), the god of his city" (Cyl. B I 15: énsi-ke ${ }_{4}$ diğir-iri-na-ke ${ }_{4}$ ) to describe himself, and Emelianov's hypothesis is that this constitutes evidence for his deification. Gudea was the first king to make Bilgames his friend (pp. 34-35). According to the author, "this indicates Gudea's obsession with the idea of immortality", leading him to the very interesting conclusion:

Gudea was the first ruler after the legendary Bilgames to be revered as a god in the era of Ur III and had several days consecrated to him for worship. He was depicted on the seals of the nobles, and the name of Gudea on these seals was preceded by the "god" determinative DINGIR. ${ }^{9}$ 
As is well known already, Gilgamesh was deified after his physical death; people prayed to him as if to a god in the hope of receiving help and support in the fight against demons and illness. Later on, in the Akkadian Epic of Gilgamesh ${ }^{10}$ from the 2nd millennium BC, Gilgamesh is referred to as a divine person in the Sumerian King List. In the Akkadian Epic of Gilgamesh, however, he is presented as being two thirds god and one third human being (Gilgamesh I: 47-48): "Gilgamesh was his name from the day he was born, twothirds of him god but a third of him human."11

In Ancient Mesopotamia, Gilgamesh was not only a protector of mankind and civilization, who fought with zoomorphic demons (bulls or lions with human heads; several motifs can be found in Mesopotamian art, especially in cylinder seals), but also in the Neo-Sumerian period he was a patron or friend and brother to the ruling king, as, for example, during the reign of Ur-Namma (2012-2094) or Šulgi (2093-2046) (e.g., p. 65). Additionally, Gilgamesh was also represented as a very important deity in the Netherworld; all these and other important aspects not listed here are also discussed in detail in this book by Vladimir Emelianov.

Whether Gilgamesh really was a historical figure ${ }^{12}$ or not is a rather complicated question that goes beyond the scope of this short review. I shall, however, mention here that V. Emelianov discusses this issue very thoroughly (pp. 28-29) and presents several interesting pieces of evidence which could be seen as supporting arguments for the hypothesis that Gilgamesh might indeed have been real. Vladimir Emelianov mentions the personal godly name from Early Dynastic Ur (late 27th century BC), Pabilgames-Utu-pada ${ }^{13}$, the crucial element being Bilgames or Pabilgames, explaining that Bilgames could therefore have been deified at this time, thus showing that there exists some probability that he was a real historical person. Emelianov concludes that the person with the name Pabilgames was chosen as lugal (king) in his city-state by the will of the sun-god Utu. He argues that the first evidence we have for the deification of Bilgames in Ancient Mesopotamia is to be found in the god list from Shurruppak, from which it is known that Bilgames had already been deified as early as in the 26th century BC (p. 29). ${ }^{14}$

In the third chapter of the first part of the book, titled "Bilgames in the Literature and Art of Sumer" (pp. 49-105), the author analyses several Sumerian epic songs about Bilgames: "Bilgames and Akka", "Bilgames and the Bull of Heaven", "The Death of Bilgames", "Bilgames and the Netherworld", and also looks into the evidence referring to Bilgames and Enkidu in Sumerian-Akkadian art. But probably the most interesting chapter in the first part of the book is the very difficult text, "The Death of Gilgamesh"15, translated (pp. 318-324) and very successfully interpreted by V. Emelianov (pp. 73-82). "The Death of Gilgamesh" is followed by the story "Bilgames and the Netherworld" (pp. 82-95), which can be considered a logical continuation of the former.

The second part of the book "Gilgamesh, King of Uruk" (pp. 106-207) also contains several chapters ("From Bilgames to Gilgamesh", "The Akkadian Epic of Gilgamesh", "The Assyrian Portrait of Gilgamesh") and is, in my opinion, the most crucial, strongest, and most original part of this monograph in which the author makes many significant observations and conclusions. Here the author deeply analyses the Akkadian Epic of Gilgamesh, including its composition and structure, also making interesting observations and presenting findings on the codes of the epic. Emelianov argues (p. 138) that 
in the epic four codes could be highlighted, one especially interesting example of which is a solar-spatial code: the path of the Sun and Gilgamesh through different countries.

All that being said, I do have some critical remarks to make. On pages 153-154 the author discusses one of the most interesting and mysterious characters in the Epic of Gilgamesh - Ur-šanabi (the issue is related to his name and his role in the epic). The author does not take into account the very interesting observations about Gilgamesh and Ur-šanabi made by Sebastian Fink in his Revue d'Assyriologie et d'Archéologie orientale (2014), which proposes interesting readings and interpretations of the name Ur-šanabi and more generally of Ur-šanabi's role in the Epic of Gilgamesh.${ }^{16}$ Other critical remarks about this book concern the absence of any summary in English. Readers unfamiliar with the Russian language will unfortunately be unable to read this excellent study on Gilgamesh, or even to get a short overview of the main points of the book and findings of the author.

The third and last part of the book, "Gilgamos, Izudbar, and Gilgamesh Again" (pp. 208-310), offers interesting information on the role of Gilgamesh in antiquity, the Middle Eastern medieval literary tradition, and also its role in modern Europe and Russian and West-European literature. We can also read about several important issues from the history of Assyriological studies that deal with Gilgamesh the person. In this last profound chapter of the study, which can even be seen as a separate research topic in itself, the author provides a summary of all evidence of Gilgamesh from antiquity and its parallels in Greek and Roman mythology and literature. He also provides analyses of Gilgamesh in the Near East (e.g., Qumran), and in Arabic and Persian medieval literature. ${ }^{17}$ Last but not least, the author also focuses on the role of Gilgamesh in modern European and Russian literature.

The book is then crowned with a neat overall summary (pp. 311-316) in which the author comes to several important conclusions and sums up his findings and observations.

The book comes accompanied with several appendices, among them an annotated translation of "The Death of Gilgamesh" (pp. 318-324) that has been reconstructed and translated very well into Russian from the Sumerian language, containing no mistakes that I could find. The translation seems to be excellent, even scrupulous. It is followed by a translation of one Neo-Assyrian incantation (pp. 324-325) which mentions Gilgamesh, ${ }^{18}$ also translated by V. Emelianov, and this appendix ends with the cycle of poetry on Izdubar, written by Russian poet A. Kondratyev in 1905 (pp. 325-336). The book also contains extensive notes and commentary of important events related to the Epic of Gilgamesh (pp. 337-354).

So, to conclude, it has to be said that it was very necessary and useful to carry out a new critical analysis of all the sources and evidence about Gilgamesh that we have from Mesopotamia, more widely from the ancient Near East, Greco-Roman antiquity, Arabian-Persian cultural spaces, and also from modern Europe and Russia. This study on Gilgamesh provides us with an innovative approach to these questions. I am therefore convinced that the book written by Vladimir Emelianov, Gilgamesh: Biography of the Legend, is a very solid and original contribution to the field of Assyriological studies that I have no hesitation to recommend for translation into English in the near future.

Vladimir Sazonov 


\section{Notes}

1 For more on Gilgamesh see Falkenstein 1957-1971; Annus 2012: 44-45; Cavigneaux \& Al-Rawi 2000; Fink 2013: 81-107; Fink 2014: 67-69; Klein 1976: 271-292; Römer 1980; Sallaberger 2013 [2008]; Schaffer 1963; Sazonov 2013: 193-197; Foster 2001.

2 See, e.g., Gilgamesh 1961; George 2003; 2007: 237-254.

3 See Emelianov 1999.

4 See more on Nabû-zuqup-kēnu in May 2018.

5 See, e.g., Cyl. B - RIME 3/1: Gudea E3/1.1.7CylB, col. xxiii, 16: "Grown as tall as Gilgameš".

${ }^{6}$ For more on the kings of Ur III dynasty see RIME 3/2; Michalowski 2008: 33-45.

7 See A praise poem of Šulgi (ك̌ulgi C), Segment A, lines 106-107 (ETCSL transliteration: c.2.4.2.03): "Like my brother and friend Gilgameš, I can recognise the virtuous and I can recognise the wicked"; see also Klein 1976: 271-292.

8 See also Emelianov 2016: 64.

9 Ibid.

${ }^{10}$ George 2003; Foster 2001; see also Schaffer 1963.

${ }^{11}$ See, e.g., Fink 2013: 82. Since the question of the deification of Gilgamesh has been thoroughly discussed in Fink's article and Vladimir Emelianov's book (2015), there is no need to focus on it here.

${ }^{12}$ See also George (1999: xxxi): "Certainly the native historical tradition held this to be the case, for Gilgamesh appears in the list of Sumerian kings as the fifth ruler of the First Dynasty of Uruk. He would thus have flourished about 2750 BC, though some would place him a century or so earlier. His reign, which the list of kings holds to have lasted a mythical 126 years, falls in the shadowy period at the edge of Mesopotamian history, when, as in the Homeric epics, the gods took a personal interest in the affairs of men and often communicated with them directly."

${ }^{13}$ See, e.g., Sallaberger 2013 [2008]: 47.

${ }^{14}$ See Krebernik 1986: 161-204.

${ }^{15}$ Cavigneaux \& Al-Rawi 2000.

${ }^{16}$ See Fink 2014: 67-69.

${ }^{17}$ See, e.g., Dalley 1991: 1-17.

18 Translated by Alan Lenzi (2011: 136-141). 


\section{References}

Annus, Amar 2012. Louvre Gilgamesh (AO 19862) Is Depicted in Life Size. Nouvelles Assyriologiques Bréves et Utilitaires (NABU), No. 32, pp. 44-45.

Cavigneaux, Antoine \& Al-Rawi, Farouk N. H. 2000. Gilgameš et la mort: Textes de Tell Haddad VI avec un appendice sur les texts funéraires sumériens. Cuneiform Monographs 19. Groningen: Styx Publications.

Dalley, Stephanie 1991. Gilgamesh in the Arabian Nights. Journal of the Royal Asiatic Society, Vol. 1, pp. 1-17. http://dx.doi.org/10.1017/S1356186300000031.

Emelianov, Vladimir 1999. Nippurskii kalendar' $i$ ranniaia istoriia zodiaka. [The Nippur Calendar and the Early History of Zodiac.] St. Petersburg: Peterburgskoe Vostokovedenie. Available at https://www.academia.edu/2588037/, last accessed on 25 March 2019.

Emelianov, Vladimir 2016. The Identity of Gudea as a Cultural and Historical Problem. In: Thomas R. Kämmerer \& Mait Kõiv \& Vladimir Sazonov (eds.) Kings, Gods and People: Establishing Monarchies in the Ancient World. Alter Orient und Altes Testament, Band 390/4. Münster: Ugarit-Verlag, pp. 63-76. Available at https:// www.academia.edu/29096892/, last accessed on 25 March 2019.

ETCSL = The Electronic Text Corpus of Sumerian Literature 1998-2006. Compiled by J. Black \& G. Cunningham \& J. Ebeling \& E. Flückiger-Hawker \& E. Robson \& J. Taylor \& G. Zólyomi. Available at http://etcsl.orinst.ox.ac.uk/, last accessed on 27 March 2019.

Falkenstein, Adam 1957-1971. Gilgameš. A. Nach sumerische Texten. Reallexikon der Assyriologie, Vol. 3, pp. 357-363.

Fink, Sebastian 2013. The Genealogy of Gilgamesh. Classica et Christiana, Vol. 8, No. 1, pp. 81-107. Available at http://history.uaic.ro/wp-content/uploads/2013/01/ Classicacc812013.pdf, last accessed on 25 March 2019.

Fink, Sebastian 2014. Gilgamesch und Urschanabi. Revue d'Assyriologie et d'Archéologie orientale, Vol. 108, No. 1, pp. 67-69. https://doi.org/10.3917/assy.108.0067.

Foster, Benjamin R. (ed. \& transl.) 2001. The Epic of Gilgamesh. Norton Critical Editions. New York \& London: W. W. Norton \& Company.

George, Andrew R. 1999. The Epic of Gilgamesh: A New Translation. London \& New York: Penguin Books. Available at https://archive.org/details/12CPReadingThe EpicOfGilgamesh, last accessed on 25 March 2019.

George, Andrew R. (ed.) 2003. The Babylonian Gilgamesh Epic: Introduction, Critical Edition and Cuneiform Texts. Oxford: Oxford University Press.

George, Andrew R. 2007. The Gilgameš Epic at Ugarit. Aula Orientalis, Vol. 25, pp. 237-254. Available at http://www.aulaorientalis.org/aulaorientalis_xxv_2_2007. html, last accessed on 25 March 2019.

Gilgamesh 1961 = Epos o Gil'gameshe: Perevod s akkadskogo. [The Epic of Gilgamesh: Translation from Akkadian.] Translated by I.M. Diakonov. Moscow \& Leningrad: Izdatel'stvo Akademii nauk SSSR.

Krebernik M. 1986. Die Götterlisten aus Fara. Zeitschrift für Assyriologie, Vol. 76, pp. 161204. Available at http://archiv.ub.uni-heidelberg.de/propylaeumdok/1125/1/ Kebernik_Die_Goetterliste_aus_Fara_1986.pdf, last accessed on 27 March 2019. 
Klein, Jacob 1976. Šulgi and Gilgameš: The Two Brother-Peers. In: Barry L. Eicher (ed.) Kramer Anniversary Volume: Cuneiform Studies in Honor of Samuel Noah Kramer. Alter Orient und Altes Testament 25. Neukirchen-Vluyn: Butzon \& Bercker, pp. 271-292. Available at https://archive.org/details/KramerAnniversaryVolume, last accessed on 26 March 2019.

Lenzi, Alan (ed.) 2011. Reading Akkadian Prayers and Hymns: An Introduction. Ancient Near East Monographs 3. Atlanta, GA: Society of Biblical Literature.

May, Natalie N. 2018. The Scholar and Politics: Nabû-zuqup-kēnu, His Colophons and The Ideology of Sargon II. In: N.V. Kozlova (ed.) Proceedings of the International Conference Dedicated to the Centenary of Igor Mikhailovich Diakonoff(1915-1999). Transactions of the State Hermitage Museum XCV. St. Petersburg: The State Hermitage Publishers, pp. 110-164. Available at https://www.hermitagemuseum. org/wps/portal/hermitage/research/publications/pub/trudy95/?lng=, last accessed on 26 March 2019.

Michalowski, Piotr 2008. The Mortal Kings of Ur: A Short Century of Divine Rule in Ancient Mesopotamia. In: Nicole Brisch (ed.) Religion and Power: Divine Kingship in the Ancient World and Beyond. Chicago: The Oriental Institute, pp. 33-45. Available at https://www.academia.edu/259963/, last accessed on 26 March 2019.

RIME 3/1 = Edzard, Dietz-Otto 1997. Gudea and His Dynasty. The Royal Inscriptions of Mesopotamia. Early Periods, Vol. 3/1. Toronto \& Buffalo \& London: University of Toronto Press.

RIME 3/2 = Frayne, Douglas R. 1997. Ur III Period (2112-2004). The Royal Inscriptions of Mesopotamia. Early Periods, Vol. 3/2. Toronto \& Buffalo \& London: University of Toronto Press.

Römer, Willem H. Ph. 1980. Das sumerische Kurzepos "Bilgameš und Akka”: Versuch Einer Neubearbeitung. Alter Orient und Altes Testament 209/1. NeukirchenVluyn: Butzon \& Bercker.

Sallaberger, Walther 2013 [2008]. Das Gilgamesch-Epos: Mythos, Werk und Tradition. München: Verlag C.H. Beck.

Sazonov, Vladimir 2013. On the Epic of Gilgamesh in Estonian. Book review. Folklore: Electronic Journal of Folklore, Vol. 53, pp. 193-197. Available at http://www. folklore.ee/folklore/vol53/b02.pdf, last accessed on 25 March 2019.

Schaffer, Aaron 1963. Sumerian Sources of Tablet XII of the Epic of Gilgameš. Diss. (PhD Thesis). University of Pennsylvania.

Selz, Gebhard J. 2005. Sumerer und Akkader: Geschichte, Gesellschaft, Kultur. München: Verlag C.H. Beck. 

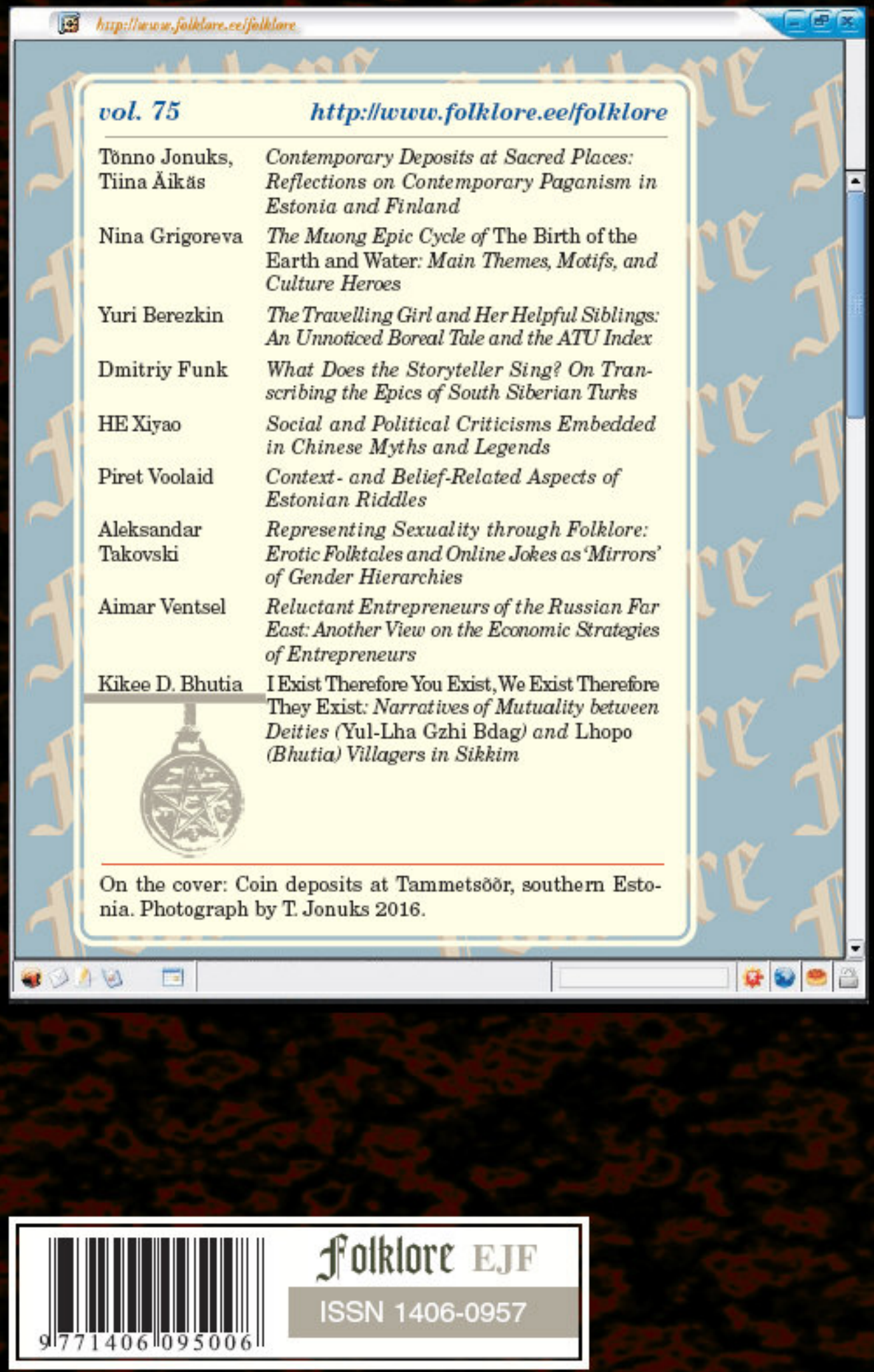